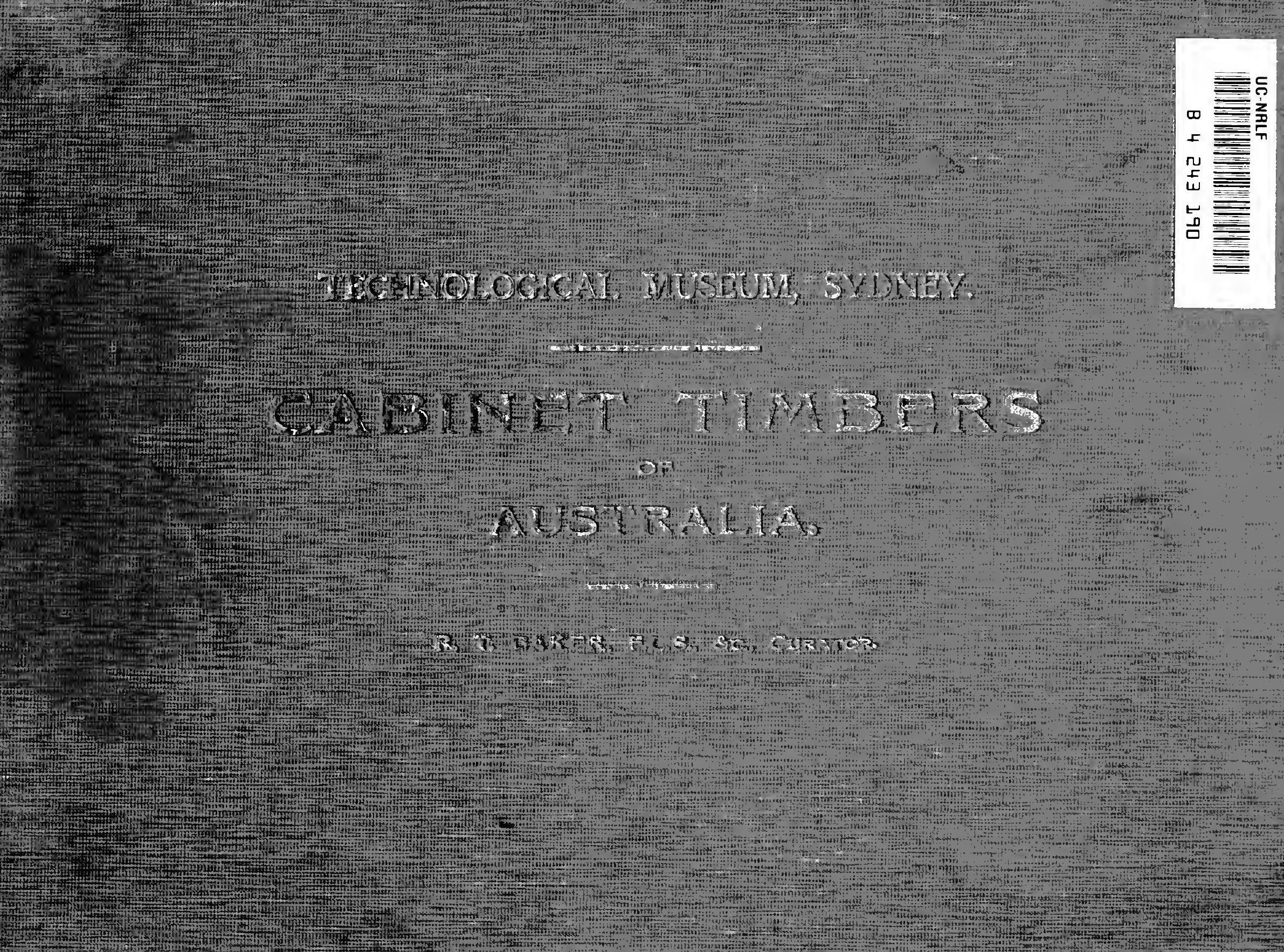



F.

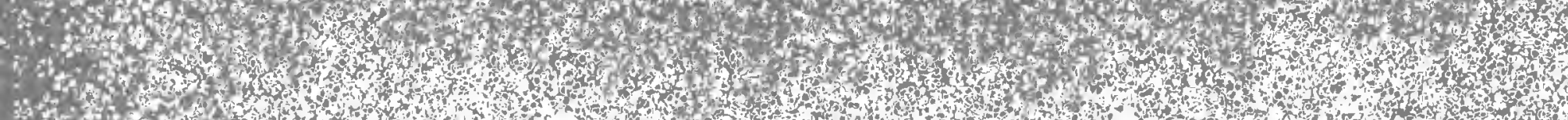

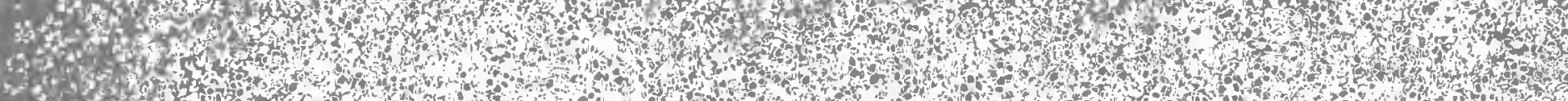

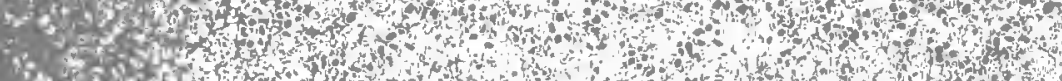

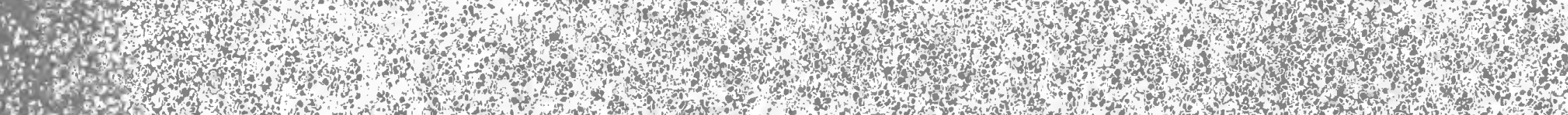

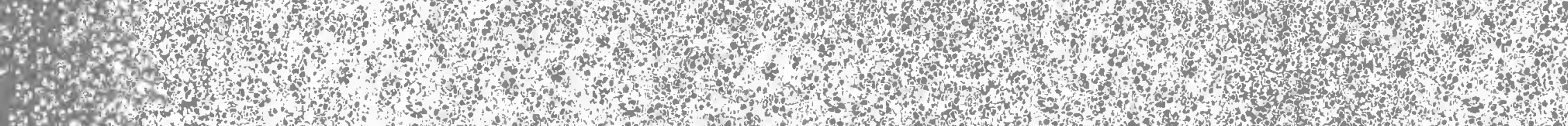

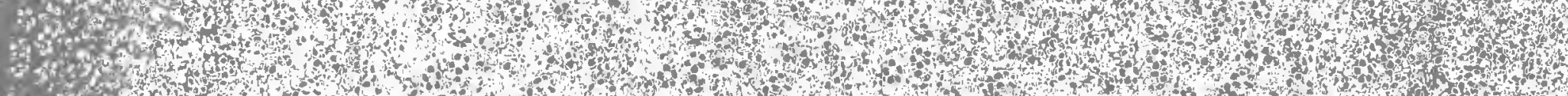

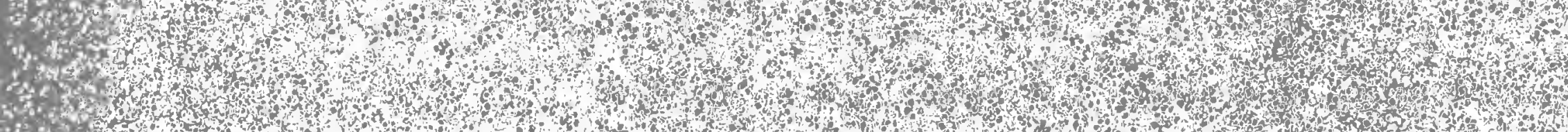

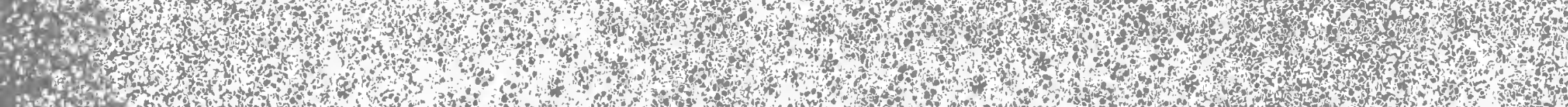

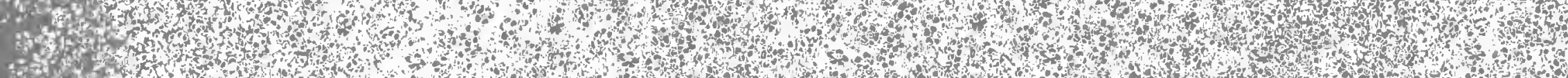

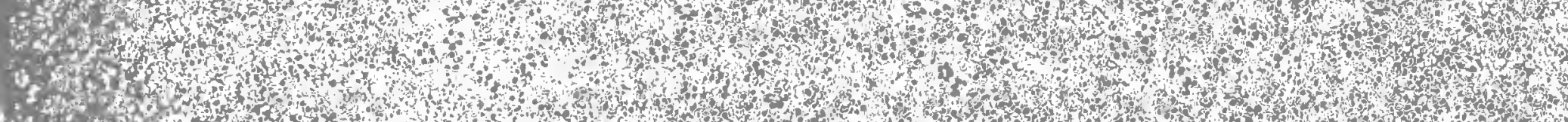

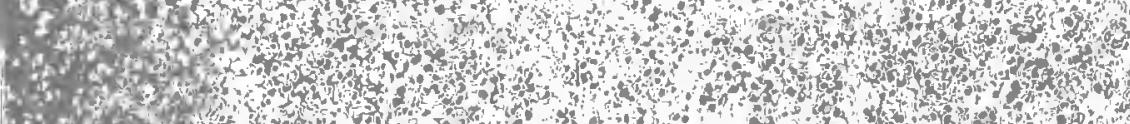

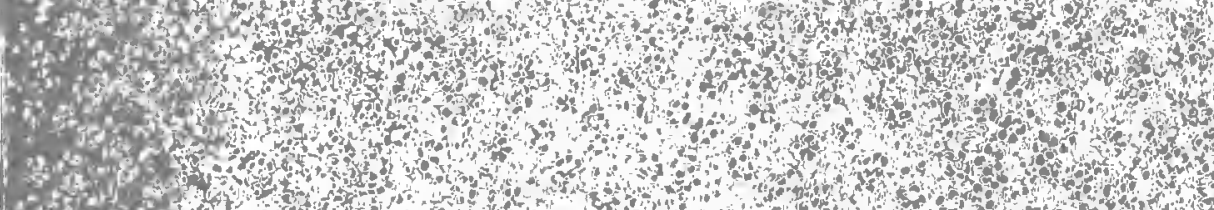

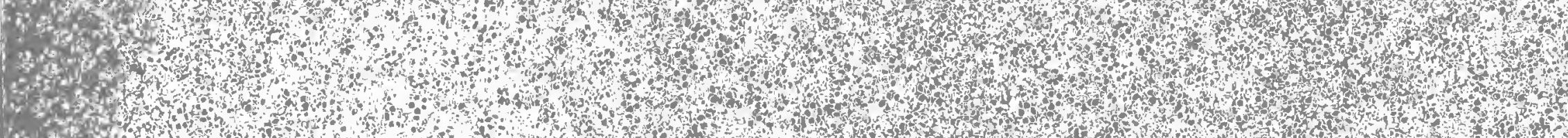

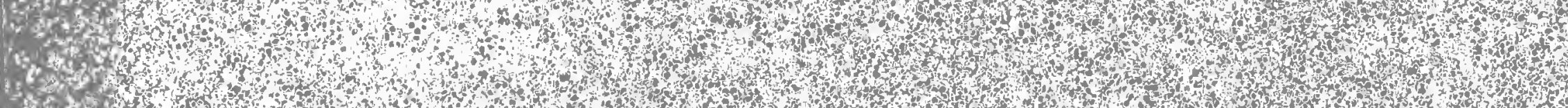

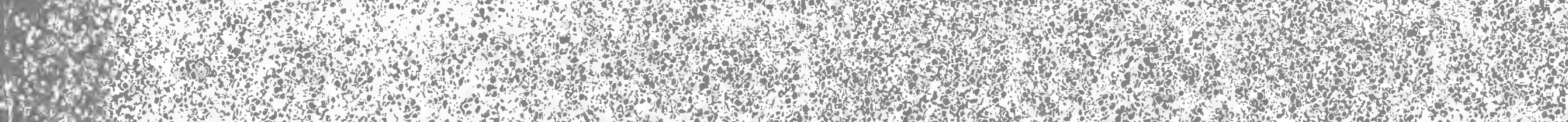

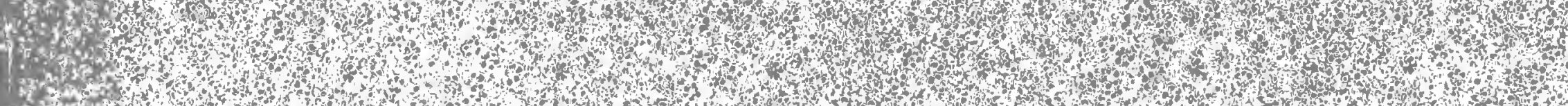

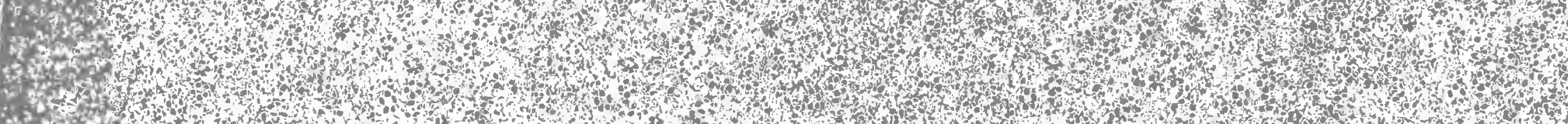

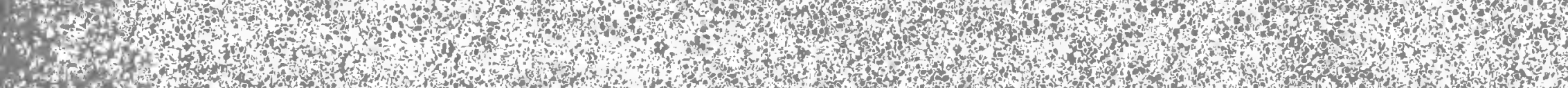

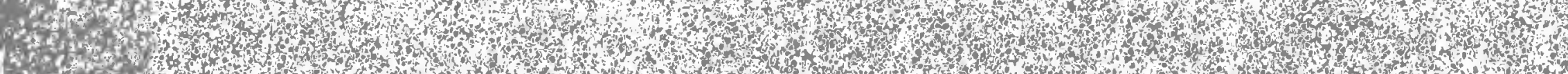

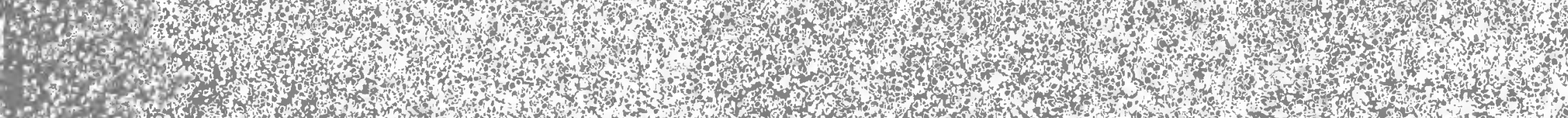

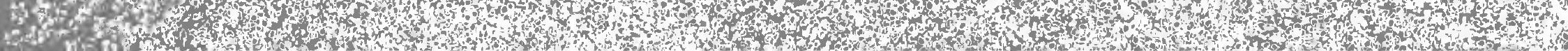




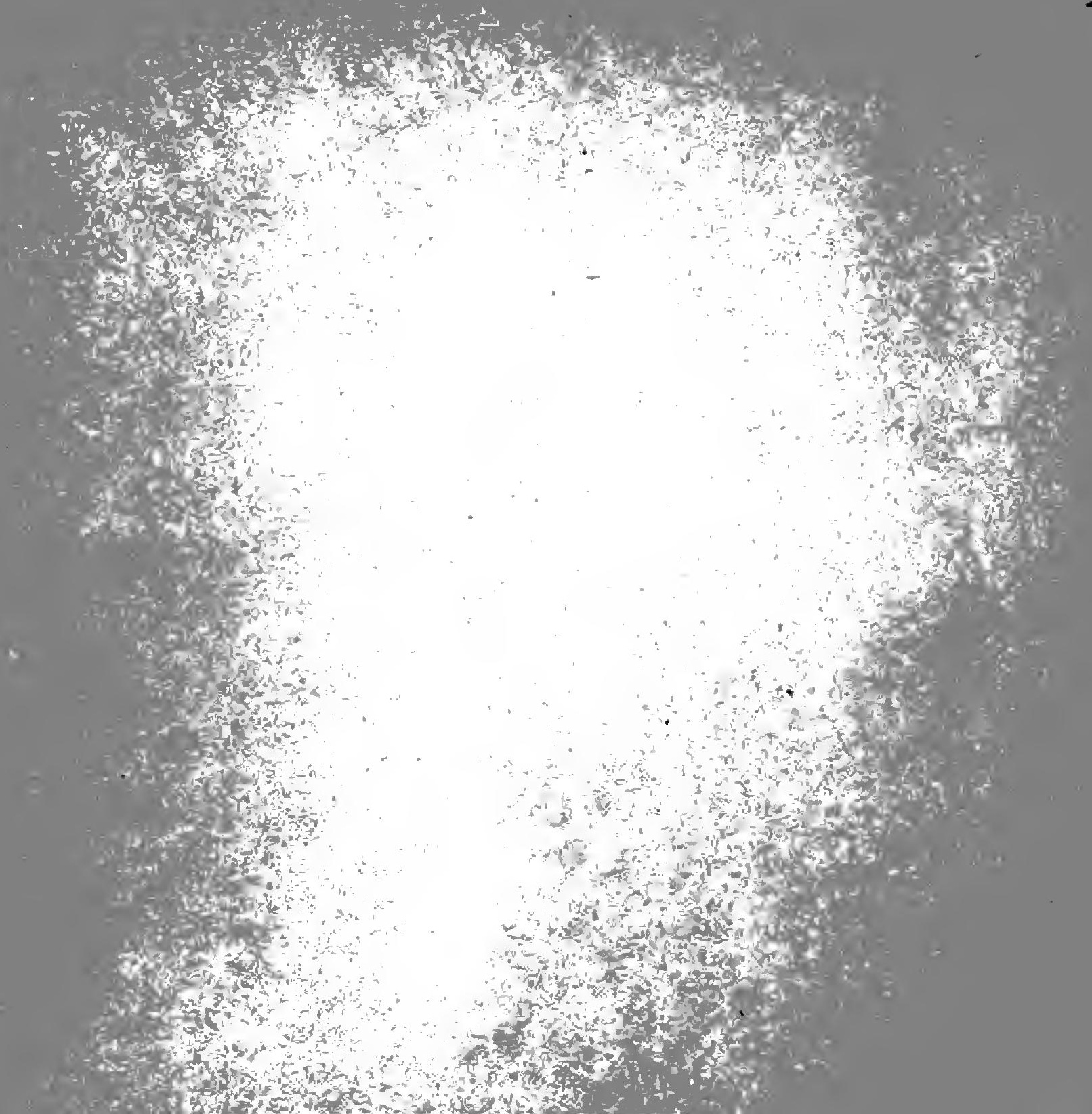




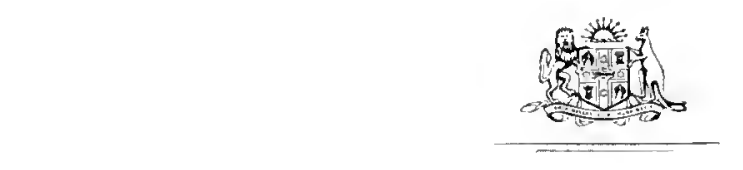

\section{DEPARTMENT OF PUBLIC INSTRUCTION.}

ftinistri:

The Hon. A. C. CARMiCHAEL, M.L.A.

OMturr Serrtary:

PETER BOARD, Esq., M.A. 


\section{Digitized by the Internet Archive in 2007 with funding from Microsoft Corporation}




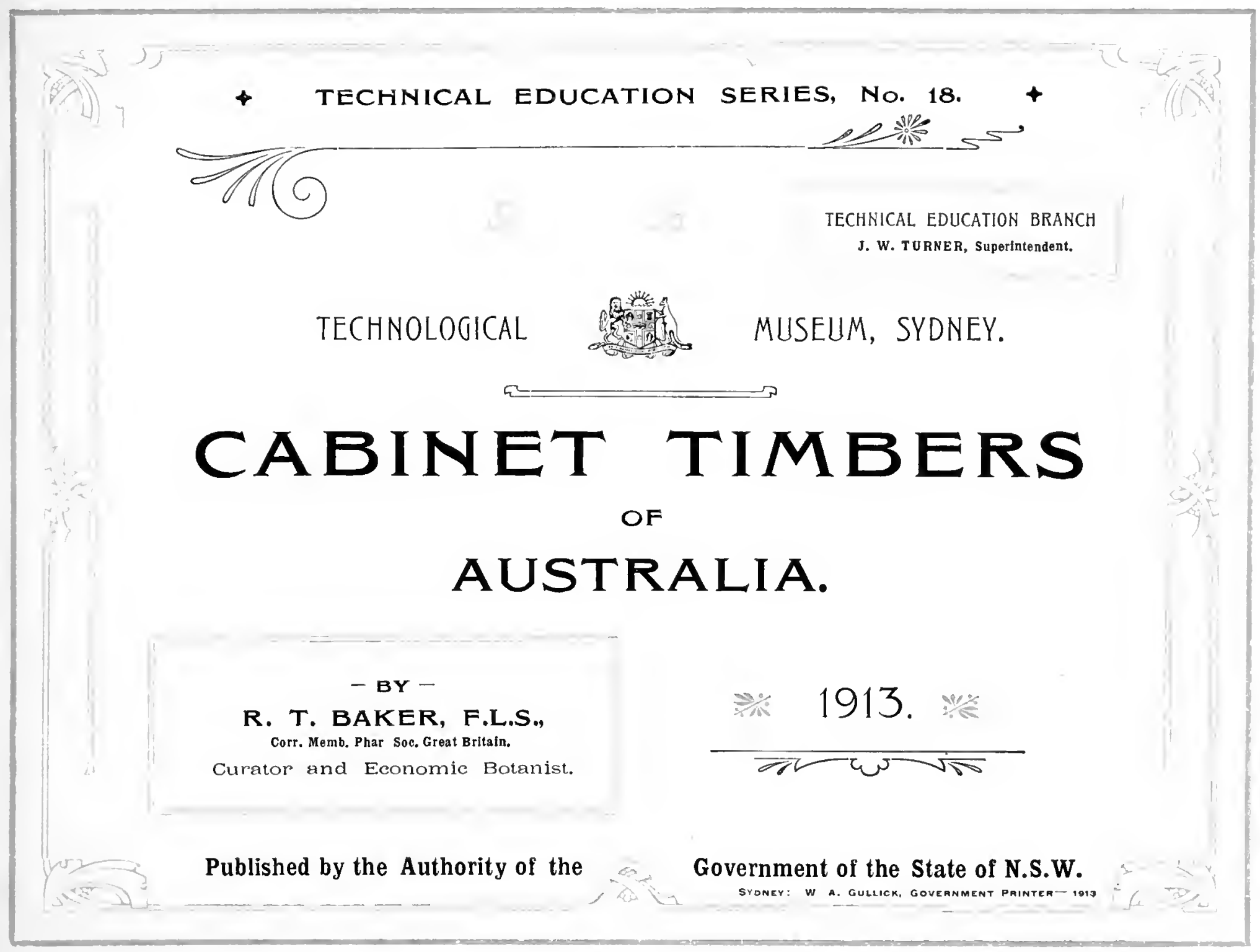




\section{The 羽asing of the Jforest.}

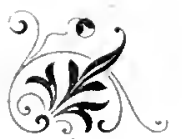

Keen is the axe, the rushing fire streams bright,

Clear, beautiful and fierce it speeds for man.

The Master, set to change and stern to smile,

Bronzed pioneer of nations. Ay, but scan

The ruined beauty wasted in a night,

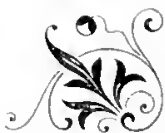

The blackened wonder God alone could plan.

And build not twice! A bitter price to pay

Is this for progress-beauty swept away.

W. P. Reves. 


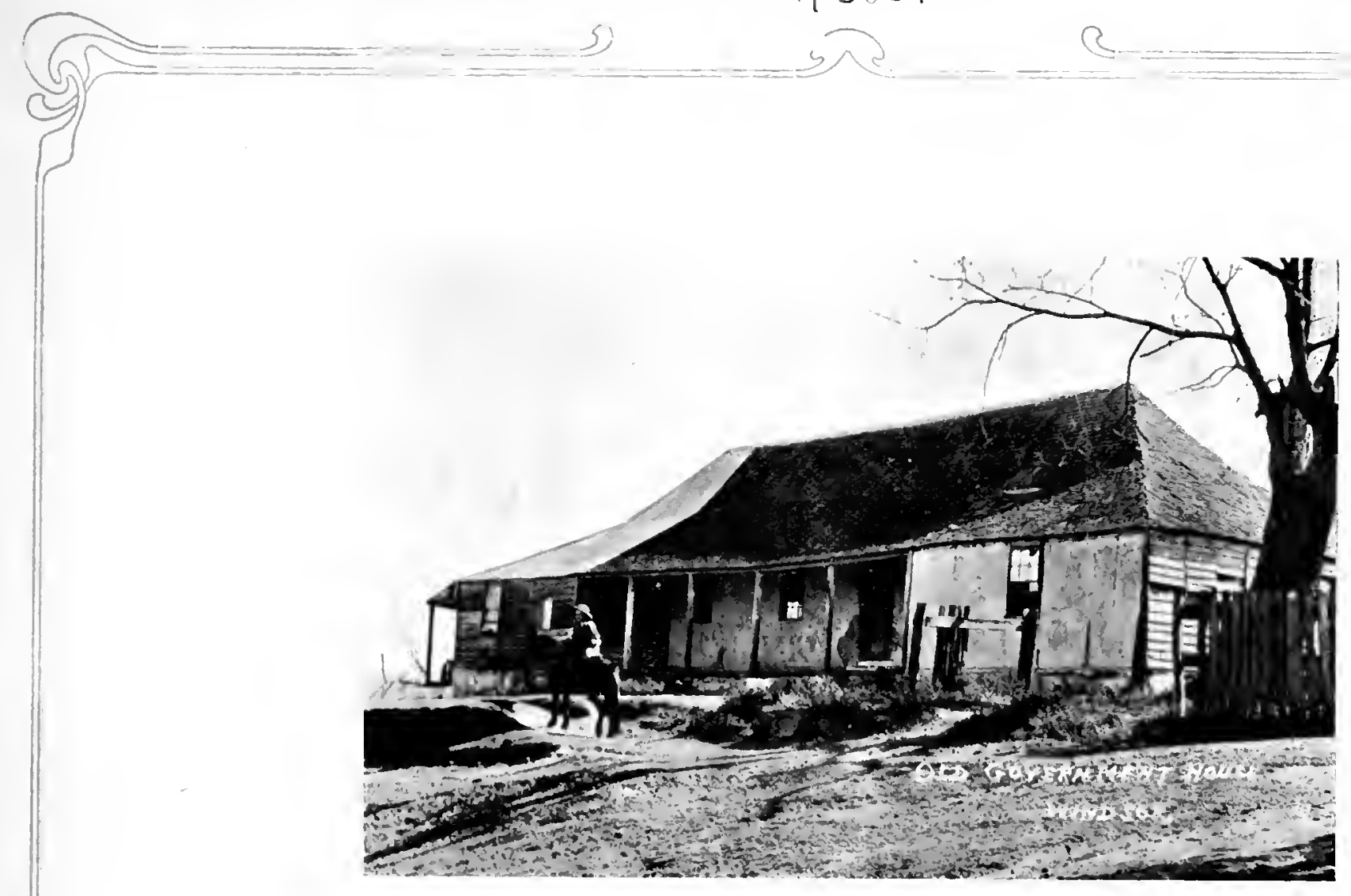

It was in the neighbourhood of Windsor-the Hawkesbury-that the first Cabinet Timber of Anstralia was obtained, viz.. "Red Cedar," and this is probably the house-crected about 1796 -in which it was first usecl. The floors, skirtings, mantelpieces, doors, windows, and even the weatherboards were made of this timber and these are all in a good state of preservation to-day, r9:3. 


\section{Contents.}

PAGE.

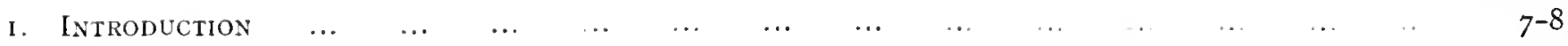

2. Preface

3. Cabinet Timbers of Australia...

4. List of Timbers, arranged in Botanical Sequence

5. List of lliustrations of Timbers in Natural Colours

6. List of Illustrations in Biack aNd White, showing how some of the various Tinibers $\begin{array}{llllllllllllllll}\text { ARE UtILISED } & \ldots & \ldots & \ldots & \ldots & \ldots & \ldots & \ldots & \ldots & \ldots & \ldots & \ldots & \ldots & \ldots\end{array}$

7. Description of each individual Tumber, Botany of the Tree, and its Geograpiucal Range

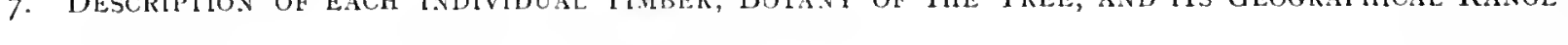

$24-173$

8. Suggested Uses for Australian Cabinet Timbers

$\cdots$

9. Types of Siecific Gravity ...

io. Summary of data concerning each Species

II. INDEX 


\section{Introduction. \\ ge ye}

(By the Minister of Public Instruction.)

THE cesthetic and utilitarian purposes to which our native timbers lend themselves have been cmphasised

in many directions in the past, but the special adaptation of a section of them for cabinet work is now conclusively shown by Mr. R. T. Baker in this publication.

As he mentions, it did not take the first settlers long to find out and appreciate such a valuable cabinet timber as our "Red Cedar," the history of which he has traced back to practically the foundation of the Colony. Such a valuable timber as this should not be lost sight of in the reafforestation now about to be undertaken by the Forestry Department of this State, for after one hundred years it still ranks as a first-class cabinet timber.

The colour, figure, and other characteristics here portrayed of the various species, by colour photography, will no doubt come as a revelation to all who are not intimately acquainted with the timbers themselves; and these coloured illustrations speak louder than words, and at the same time demand that action should no longer he delayed in the culture of such fine specimens of the cabinet-maker's desiderata.

Such a technical work as this shows without doubt that our forest trees are worthy of more attention than has been given them in the past, and that they deserve to be still better known in the future.

The late Baron von Mueller, the greatest student of the great Australian genus Eucalyptus, never tired of singing the praises of the trees of that genus, for their technological value, but in no instance is there a record where he predicted their utilisation for cabinet work, and yet here Mr. Baker graphically demonstrates that several species are indeed well adapted for this special handicraft. 
In one particular group of Eucalyptus-the Stringybarks-it has passed the experimental stage, and is now a fait accompli, for in Tasmania and Sydney some fine samples of the eabinet-maker's art made from these trees are being placed on the market. Facts like these should bring home to the Australian the value of our timbers, and inculcate a higher appreciation of their virtue than perhaps we have been prepared to assign to them in the past.

A part from the cabinet-maker, these illustrations will undoubtedly serve another very useful purpose, for $1 \mathrm{am}$ sure the technical students of the various branches of decorative art of to-day and the future will use this work for reference, for there they will find ready to hand and true to life, the natural colour and graining of our Australian timbers.

The purpose of this work is primarily to give information to the trade concerning the specific characteristics of respective woods that may be classed as cabinet; also to show to the timber merchant the approximate locality where the trees are to be found, and for his field guidance a botanical description of each is added.

I think it will be admitted that by the bringing together of such data, Technical Education in New Soutl W Wales has placed the cabinet world, and others interested in the subject, under an obligation; and 1 have little doubt but that the effort of Mr. Baker will be generally appreciated, as will also that of the Government Printer and his staff, who have executed this technical work in the highest class of printer's art.

\section{CAMPBELL CARMICHAEL.}

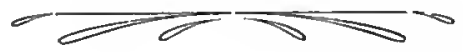




\section{Preface.}

SEVlikal factors were instrumental in bringing about the writing of this publication, and not the least important of these is a desire to produce amongst Australians a higher appreciation of their own native timbers in this one particular branch of Teehnology, vi\%, eabinet work and its allied trades. Another was that some of these beatiful woods, owing to the rapid advance of the settler, are in jeopardy of being exterminated altogether, and that by bringing these in this form before the commercial world, it is hoped the various Forestry Departments of the Commonwealth may be moved to set apart reserves for their reafforestation before it is too late.

ERRATUM.

Pages 65-90 and coloured plate for

Astcil homalophylla, A. Cunn., read A. harpophylla, F.v.M.

a new ficld of work timbers copied now

s dead as the Dodo, usly published work impted before.

able national asset, layed no small part

I of the varied and

R.T.13.

1912.

\section{ACKNOIVLEDGMIENT.}

To the following officers of the Museum $m y$ thanks are due for assistance rendered in the preparation of this work:-Messrs. C. Still, 1). Cannon, and L. G. Irby. 
In one particular group of Eucalyptus-the Stringybarks-it has passed the experimental stage, and is now a fait accompli, for in 'Tasmania and Sydney some fine samples of the cabinet-maker's art made from these trees are being placed on the market. Facts like these should bring home to the Australian the value of our timbers, and inculcate a higher appreciation of their virtue than perhaps we have been prepared to assign to them in the past.

A part from the cabine for I am sure the technical s use this work for reference, graining of our Australian

The purpose of thi: characteristics of respectiv approximate locality wher each is added.

I think it will be admittem _undoubtedly serve another very useful purpose, - of to-dar and the future will

Wales has placed the cabinet world, ang

and I have little doubt but that the effort of Mr. Baker will be generan.

of the Government Printer and his staff, who have executed this technical work in the $\mathbf{m}^{-5}$

printer's art.

\section{CAMPBELL CARMICHAEL.}

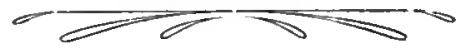




\section{Preface.}

SEVERAL factors were instrumental in bringing about the writing of this publication, and not the least important of these is a desire to produce amongst Australians a higher appreciation of their own native timbers in this one particular branch of Technology, viz, cabinet work and its allied trades. Another was that some of these beatiful woods, owing to the rapid adrance of the settler, are in jeopardy of being exterminated altogether, and that by bringing these in this form before the commereial world, it is hoped the various Forestry Departments of the Commonwealth may be moved to set apart reserves for their reafforestation before it is too late.

To the students of our Technical Colleges it will supply a desideratum by giving a new field of work from which to reproduce the graining of Australian woods instead of the old world's timbers copied now for generations.

As it is, 1 often look at these timbers and wonder if they will not shortly become as dead as the Dodo, but still I hope their conservation is now near at hand. As far as I am aware, no previously published work is devoted entirely to the subject, nor have coloured illustrations of our timbers been attempted before.

That our cabinet-makers might be moved to take a greater interest in such a valuable national asset, by utilising in a greater measure in the future than has been the custom in the past, also played no small part in its preparation.

At any rate, its publication will, 1 hope, serve at least as another historical record of the varied and valuable resources of Australia's wonderful forests.

1912.

R.T.B.

\section{ACKNOWLEDGMENT.}

To the following officers of the Museum my thanks are due for assistance rendered in the preparation of this work:-Messrs. C. Still, 1). Cannon, and 1.. G. Irby. 


\section{Cabinet Timbers of Australia. \\ te of at}

NATURE, as in many other directions, las not been niggardly as regards its endowment of beatiful and decorative timbers in this lsland Continent of ours, for it is almost impossible to make even a modest collection of woods without the ornamental character of one or other of them appealing to the artistic eye.

This Institution has always made a prominent feature of the timber resources of Australia in particular, and the world in general, so that to-day it probably has only one rival in its comprehensiveness, vi\%, that of the Royal Botanic Gardens, Kew, England.

The Australian samples here date a long way back in colonial history, for some of the specimens were exhibited at the Great International Exhibition of 1851 , at Paris 1855 , London 1862 , and some of even earlier date than this in local exhibitions, whilst others have a history going back almost from the foundation of the Colony. Many of these specimens were for long scattered amongst the various Government Departments in Sydney, but about 1882 they were brought together, and so was laid the foundation for this extensive collection.

Naturally, such a collection, which numbers not less than 5,ooo, divides itself into groups of various branches of economics. Not the least amongst these is the section devoted to cabinet and ornamental timbers, and it is in the interest of these that the present work has been undertaken.

Some of the specimens in this category rival those of other countries for figure, grain, weight, texture, and for general decorative purposes, and are unique in many other respects. Thus, whilst these qualities are claimed for them in general, yet it may also be said that they possess characteristic features that distinguish them as Australian. 
Foremost anongst such timbers is perhaps the "Red Cedar," Coirela Troma, which has extended its range south from the Malay Peninsula into Queensland and New South Wales. Taken all in all, it is considered the best all-round timber in Australia, and is still in great demand for counters and internal woodwork decoration, although in recent years, for furniture making it has gone out of fashion. It was probably the very first timber to which cabinet-makers' attention was seriously drawn at the inception of the trade in the early days of the Colony. "The first mention of it in the Historical Records is by Collins, vol. i. p. +12, who states that the master of the ship " liancr," Captain Dell, took to England logs of cedar from the Hawkesbury River in 1795. From then onwards other similarly beautiful timbers were brought to light, as the coastal brush distriets north and south of Port Jackson were opened up. Then followed settlement in other States, and so new decorative timbers came to be known, and to these have been added from time to time a few from the interior; but it must be admitted that the typical Australian Flora of those parts is rather wanting in ornamental woods - at least, produces only a limited number.

It is well known that we possess such beautiful woods like Blackwood, Maples (Q., Tas., and N.S. W. ), Silky Oak, Walnut, Red Bean, Jarrah, and many others, which are all first-class timbers for this particular industry.

At the present time the fashion is "Oak," and so large quantities of Japanese "Oak" (sic) are being used in the furniture trade as a rival to English Oak, which it resembles in figure, but is considerably lighter in weight and more open in texture. Although Australial has no true Oak of the Quercus family, yet it may be mentioned cn passunt, that there is here an extensive supply of so-called native Oaks in our Casuarinas, which extend over a great part of the Continent. With the exception of "Belah "these trees have a figure quite like the English Oaks, and are of equal hardness, but show a slight variation of colour through the different species, ranging from a true Oak colour to a deep red, or almost black. There seems no reason why these Australian Oaks should not command a premier position as an ornamental, decorative, and furniture timber, as they possess all the desiderata such as supply, relative cheapness, and capability of sustaining a high polish, combined with a beauty in figure. 
With our Eucalyptus (gum trees) little has been done to test their qualities in this line, although one of the first common names applied to them was in connection with cabinet nomenclature, vi\%, "Mahogany,"-this designation being bestowed upon Eucalyptus resinifera, Sm., by the first settlers at Port Jackson, where it was then a common tree. Later, however, it was found that there were other trees far more cleserving the appellation as they more nearly approached in colour and texture the original Mahogany, Sivictcria Mahogani from Honduras. Western Austratians and Tasmanians, however, are losing no opportunity of bringing their beautiful Eucalyptus timbers before the British public, for at the Imperial lnstitute there is exhibited some fine suites of furniture and other samples of the cabinet-makers' art in Karri and Jarrah, and these are an object lesson to the other States in the matter of a better utilisation of some of the Eucalypts in this direction. Our Red Boxes, Red Gums, Slaty Gum, and others are very suitable for special lines of this branch of technology.

Before leaving the Eucalypts, a word must be said in praise of our much despised "Stringybarks" for cabinet work, for it is in them that Australia has an excellent substitute for the imported "Oaks," and what is of great importance, the supply is unlimited for many years to come.

For the utilisation of "Stringybarks" in Applied Art, credit must be given to the Tasmanian, for in his Island home one finds the "Stringybarks' largely manufactured into furniture, office fittings, church fittings and decoration, wood-carving, panellings, and various other forms of decorative art.

For this class of work these have a particularly attractive and pleasing appearance, the two species specially selected being $E$. Delegatensis and E. obliqua; the former for preference, as it prepares well and makes very attractive articles of an "Oak" colour. Both these species occur on the mainland as well as in Tasmania, and altogether there are something like twenty species of "Stringybarks"-none of which appears ever to have been used in this direction, so here is a big field of investigation for our cabinetmakers. Thousands of "Stringybarks" have heen cut down and destroyed in the past as worthless. I regard the introduction here of the "Stringybarks" as a cabinet timber as one of the salient points in this work, for apart from other considerations the supply is apparently inexhaustible. 
Even Ironbark has been utilised for decoration in the past, for the late John Macarthur, Esq., introduced some large fluted columns of this timber in the ornamentation of the Reception or Ball Room at Canden Park House, erected in 18.34 .

With the usual cabinet timbers becoming scaree, our "Stringybarks" should no longer be neglected in this connection.

Some of the larger "Tea trees" are also good timber for this purpose, as well als one or two of the Angophoras-" Apple Trees."

Amongst soft timbers our Pines or Conifers are deserving of consideration, for, as can be seen by the illustrations here given, they possess some good qualities for cabinet work. Queensland Kauri, Brown Pine, King William Pine, Huon Pine, \&c., are beautiful timbers of their kind, and for ligure the Callitris are elegant.

In addition to the above, mention must be made of Tasmania's contribution to Australia's eabinet woods, for besides Blackwood, King William Pine, Huon Pine, and Celery Top Pine; \&c., already noted, the first also occurring on the mainland, such timbers as Red Myrtle, Leatherwood, and Stringybark are a considerable acquisition to our valuable timbers.

In order to show the adaptability of our woods and puner encouruge les antres several Government Offices in the various States are decorated with Australian Timbers, whilst Banks, Commercial Institutions, and private houses exhibit samples of them in Applied Art, and in this Museum are shown specimens of locally manufactured articles from some of these timbers. The New South Wales Government Railway Workshops are at present turning out railway passenger carriages made almost entirely of Australiatn timbers, the whole either polished or varnished, in order to bring out the natural graining and figure, ind the effect is most beautiful. These carriages as they leave the shops are real works of art.

Those here given by no means exhaust the list of Australia's eabinet timbers, but are those concerning which most clata are available. 
As regards the nomenclature of our cabinet timbers, our settlers were first in the field in bestowing vernacular names, and it is too late to alter them now, so a little care must be exercised when applying the common names, which however are a little nearer the mark than many conferred on our gum trees, for when one mentions Maple, Myrtle, Sycamore, or Walnut, the wood referred to will generally be found to possess some of the features of these exotic woods. On the other hand, in the name "gum tree" we have trees that do not yield gum; Apple trees that do not bear apples; again Blue Fig, a tree that does not bear figs, and so on.

One deplorable feature in connection with the subject has been the wanton waste of hundreds of millions of feet of the finest timber, subsequent upon the opening up of the country for settlement. Enormous. quantities of the most beatutiful timber have been felled "and cast into the fire," and in a great measure this is going on to-day. If settlement is to take place, of course the clearing of the land is inevitable, but it does seem to show a want of business capacity somewhere that the timber could not be marketed.

As only certain desirable districts are opened out, there yet remains large areas of land eminently suitable for forests, such as mountain ranges and gullies, and a considerable portion of these is practically valueless for any other purpose than timber-growing.

The original areas which grew the timber were so extensive, and the virgin supplies being so plentiful, they were looked upon as inexhaustible. However, the timber areas are decreasing, and the time has come when timber must be put on a similar footing to other crops, so that fresh supplies should be provided for.

Some choice woods like Cedar are now becoming very scarce on the New South Wales coast. In Queensland, however, the supplies are larger, and the proportion of standing timber is greater-less 
exploitation having been going on. The export of timber from Queensland has not yet reached very big dimensions, though it is grachually and steadily increasing. "There are huge areas in Queenstand of forest land occupying many miles of country, estimated at 40,000,000 acres, yet uninspected and unreserved, which one day will be thrown open to the timber-getter's axe, and the trader's activities. Masses of Pine trees, Silky Oak, \&c., still exist. There are now reserved about three or four million acres, and the operations of the timber merchants cover a considerable area, but yet small in comparison with the extent of the forest land. . . . . . . . Such choice woods as Silky Oak, Pencil Cedar, Rosewood, Tulip Wood, and Red Oak, besides many others that are abundant, are unrivalled for furniture making, eabinet work, and fine veneers." ("Dalgety's Review.")

However, before it is too late, and the supply of our beautiful cabinet timbers completely exhausted, it is hoped the Forest Departments of the Commonwealth States will take action to prevent such a national calamity.

If the publication of this letterpress and these illustrations should be productive of action that will lad to the perpetuation of our valuable trees and species in this connection, before the last tree sheds its seed and passes into the limbo of oblivion, this work will not have been published in vain.

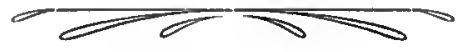




\section{Timbers Described. \\ (ARRANGED IN BOTANICAI. SEQUENCE.)}

*I. Crowsfoot Elm (Tarrietia argyrodendron $) \quad \ldots \quad$... $\quad \ldots \quad$... Sterculiacer.

*2. Maiden's Blush (Echinocarpus aus. tralis, Benth.) ‥ … ... Tiliacer.

*3. Blue Fig (Elaocarpus grandis) $\quad \ldots \quad$ do

*. Thorny Yellow IVood (Zanthoxylum brachyacanthum) ... $\quad . . \quad$... Rutacex.

*5. Scrub Hickory (Pentaceras australis) do

*6. White Cedar (Melia Azedarach) ... Meliaceæ.

*7. Rosewood (Dy'soxylon Fraserianum) do

*8. Red Bean (I). Muelleri) . ... do

a. Onion Wood (Orenia cepiodora) ... do

* Io. Red Cedar (Cedrela Toona, Roxb.)... do

*I. Long Jack (Flindersia Oxleyana) ... do

*I2. Queensland llaple (F. Chatarai-

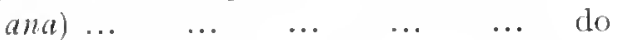

*I3. New South Wales Maple (Villaresia Moorei) ... ... ... ... Olacinea.

I4. Supple Jack (I'entilago viminalis) ... Rhamnex.

15. Red Ash (Alphitonia excelsa) ... do

* I6. Tulip Wood (Harpullia pendula) ... Sapindacex.
*I7. Yellow Cedar (Rhodosphcera rhodun. thema) $\quad . . \quad \ldots . \quad \ldots \quad$... Anacardiacex.

* * I8. Black Bean (Castanospermum australc) $\quad \ldots \quad \ldots \quad \ldots . \quad \ldots$ Legiminosæ.

*I9. Eumung (Acacia salicina) $\ldots$... do

*2o. Sally (A. Maideni) $\quad \ldots \quad$... $\quad \ldots \quad$ do

*2I. Blackwood (A. melanoxylon) ... do

*22. Myall $(A$. pendula) $\ldots \quad$.. $\quad \ldots \quad$ do

*23. Brigalow (A. homalophylla) ... ... do

*24. Gidgea (A. Cambagei) ... $\quad$...

$*_{25}$. Tortoise Shell Tulip (Pithecolobium Hondersoni) $\quad \ldots \quad$... $\quad \ldots \quad$ do

*26. Coachwood (Ceratopetalum apetalum) Saxifragea.

*27. Corkwood (Ackama Muclleri) ... do

*28. A N.S.IV. Mountain Ash or Tas. manian Oak (Eucalyptus Delegatensis) $\ldots \quad \ldots \quad \ldots \quad \ldots \quad$... Myrtacex.

*29. A Stringybark (E. obliqua) ... ... do

*3o. Mahogany (E. resinifera) ... ... do

\*3I. Jarrah (E. marginata) ... ... do

*32. Red Box (E. Rudderi) ... ... - do

*33. Spotted Gum (E. maculata) ... do

* Illustrated in colour. 


\section{Timbers-continued.}

*34. Blue Gum (Eucalyptus saligna) ... Myrtaceæ.

*35. Slaty Gum (E. Dawesoni) $\quad . . \quad$... $\quad$ do

*36. Musk, Olearia (Astcr) argophylla ... Compositr.

*37. Budda (Eremophila Mitchelli) ... Myoporinex.

*38. Beech (Gmelina Leichhardtii) ... Verbenaceæ.

*39. Sassafras (Doryphora sassafras) ... Monimiaceæ.

*40. Queensland Walnut (Cryptocarya Palmerstoni) $\quad$... $\quad$... ... Laurineæ.

*4I. She Beech, or Bolly Gum (Tetranthera reticulata) $\quad \ldots \quad \ldots \quad \ldots \quad$ do

*42. Silky Oak (Orites excelsa) ... ... Proteaceæ.

43. Silky Oak (Grevillea robusta)... ... do

*44. Beefwood (G. striata) $\quad$.. $\quad \ldots \quad$ do

*45. Victorian Waratah (Telopea oreades) do

*46. Tasmanian Waratah (T. truncata) do

*47. Fire tree (Stenocarpus sinuatus) ... do

${ }_{4}^{4} 8$. White Honeysuckle (Banksia integrifolia), plain figure...
(.).

do
49. River Ouk (Casuarina Cunninghamii) Casuarinex.

*50. Swamp Oak (C. glauca) … ... do

*5I. Bull Oak (C. Luehmanni) .. $\quad$... do

*52. Belah (C. Cambagei) ... ... ... do

*53. Forest Oak (C. torulosa) .. $\quad \ldots$ do

*54. Red Myrtle (Fagus Cunninghamii)... Cupuliferæ.

*55. Cherry (Exocarpus cupressiformis) ... Santalaceæ.

${ }_{5} 6$. White Pine (Callitris glauca) _.. Coniferæ.

*57. Black Pine $(C$. calcarata $)$... ... do

$*_{5} 8$. King William Pine (Athrotaxis selagi$\begin{array}{llllll}\text { noides }) & \ldots & \ldots & \ldots & \ldots & \text { do }\end{array}$

*59. Hoop Pine (Araucaria Cunninghamii) do

*6o. Bunya Bunya (A. Bidwilli) ... ... do

*6r. Queensland Kauri (Agathis robusta)... do

*62. Huon Pine (Dacridium Franklini) ... do

*63. Celery Top Pine (Phyllocladus rhomboidalis) $\quad \ldots \quad$... $\quad \ldots \quad$... do

- *64. Brown Pine (Podocarpus elata) ... do

Illustrated in colour 


\section{Illustrations in Natural Colours.}

\begin{tabular}{|c|c|c|c|c|c|c|c|c|c|c|c|}
\hline Beech & $\ldots$ & $\ldots$ & $\ldots$ & $\ldots$ & $\begin{array}{r}\text { No. of Plate. } \\
\text { XLI }\end{array}$ & Coachiwood & $\ldots$ & $\ldots$ & $\ldots$ & $\ldots$ & $\begin{array}{l}\text { No. of Plate. } \\
\text { XXVIII }\end{array}$ \\
\hline Beefwood ... & $\ldots$ & $\ldots$ & ... & $\ldots$ & XIVI & Corkwood & $\ldots$ & $\ldots$ & $\ldots$ & $\ldots$ & XXIX \\
\hline Belah $\quad \ldots$ & $\ldots$ &.. & $\ldots$ & $\ldots$ & LV & \multicolumn{4}{|c|}{ Crowsfoot Elm or Ironwood } & $\ldots$ & I \\
\hline \multicolumn{4}{|c|}{ Black Bean (Plain and Figured) } & $\ldots$ & XVIII-XIX & Eumung & $\ldots$ & $\ldots$ & $\ldots$ & $\ldots$ & $\mathrm{XX}$ \\
\hline \multirow{2}{*}{\multicolumn{2}{|c|}{$\begin{array}{l}\text { Black Pine or Cypress } \\
\text { Blackwood (Plain and }\end{array}$}} & Pine & $\ldots$ & $\ldots$ & $\mathrm{LX}$ & Fire Tree & $\ldots$ & $\ldots$ & $\ldots$ & $\ldots$ & XLIX \\
\hline & & Figured) & & $\ldots$ & XXII-XXIII & Forest Oak & $\ldots$ & $\ldots$ & $\ldots$ & $\ldots$ & LVI \\
\hline \multicolumn{2}{|c|}{ Blue Fig $\quad \ldots \quad \ldots$} & $\ldots$ & $\cdots$ & $\ldots$ & III & Gidgea ... & $\ldots$ & $\cdots$ & $\ldots$ & $\ldots$ & XXVI \\
\hline Blue Gum ... & $\cdots$ & $\cdots$ & $\ldots$ & $\ldots$ & XXXVI & Hoop Pine & $\ldots$ & $\ldots$ & ... & $\cdots$ & LXII \\
\hline Bolly Gum... & $\ldots$ & $\ldots$ & $\ldots$ & $\ldots$ & XLIY & Honeysuckle & White) & $\ldots$ & $\ldots$ & $\ldots$ & $\mathrm{L}-\mathrm{LI}$ \\
\hline Brigalow & $\ldots$ & $\ldots$ & $\cdots$ & $\ldots$ & $\mathrm{XXV}$ & Huon Pine & ... & $\ldots$ & $\ldots$ & $\ldots$ & LXV \\
\hline \multicolumn{4}{|c|}{ Brown Pine (Plain and Figured) } & $\ldots 12$ & XVII-LXVIII & Jarrah $\ldots$ & $\cdots$ & $\cdots$ & $\cdots$ & $\ldots$ & XXXIII \\
\hline Budda $\quad \ldots$ & ... & $\cdots$ & $\cdots$ & $\cdots$ & $\mathrm{XL}$ & Kauri (Quee & land) & ... & $\ldots$ & $\cdots$ & LXIV \\
\hline \multicolumn{2}{|c|}{ Bull Oak (Plain and F) } & gured) & ... & ... & LIII-LIV & King Williar & Pine & $\cdots$ & $\ldots$ & $\ldots$ & LXI \\
\hline \multicolumn{2}{|c|}{ Bunya Bunya .. } & $\ldots$ & $\ldots$ & $\ldots$ & LXIII & Long Jack. & $\ldots$ & $\ldots$ & $\ldots$ & $\ldots$ & XI \\
\hline \multirow{2}{*}{$\begin{array}{l}\text { Cedar (Red) } \\
\text { Cedar (White) }\end{array}$} & $\cdots$ & ... & ... & $\cdots$ & $\mathrm{X}$ & Maiden's Bl & h... & $\ldots$ & $\ldots$ & $\ldots$ & II \\
\hline & $\cdots$ & $\cdots$ & $\cdots$ & $\cdots$ & VI & Mahogany & $\ldots$ & $\ldots$ & $\cdots$ & $\cdots$ & XXXII \\
\hline Celery Top Pine & $\cdots$ & $\cdots$ & $\ldots$ & $\ldots$ & LXVI & \multicolumn{5}{|c|}{ MapIe(Queensland) (Plain and Figured) } & XII-XIII \\
\hline Cherry & $\ldots$ & $\ldots$ & $\ldots$ & $\ldots$ & LVIII & Maple New & outh W & ales) & $\ldots$ & $\ldots$ & XIV \\
\hline
\end{tabular}




\section{IIlustrations in Natural Colours-continued.}

No. of Plate.

Mountain Ash or Tasmanian Oak

Musk (Plain and Rootstock)

$\begin{array}{rr}\cdots & \text { XXX } \\ \text { XXXVIII-XXXIX }\end{array}$

Silky Oak...

No. of Plate

Myall

Oak (Tasmanian) ...

XXIV

Pines

XXX

Red AsI

$\cdots \quad \cdots$

Red Bean (Light and Dark

Red Box

Red Cedar ...

Red Myrtle (Tasmanian)

Ring Gidgea

...

Rosewood

Sally

Sassafras

... $\ldots$

...

4

Slaty Gum

$\cdots$

Spotted Gum

Stringy Bark

Swamp Oak

Thorny Yellow Wood ...

Tortoise Shell Tulip ..

Tulip Wood

Walnut (Queensland)...

.. $\ldots$

XLV

XXXVII

XXXV

XXXI

LII

IV

XXVII

XXXIV

$\mathrm{X}$

$\cdots \quad$ LVII

Scrub Hickory

XXVI

VII

XXI

XLII

Waratah (Tasmanian) ...

XVI

IVaratah (Victorian) $\ldots \quad \ldots \quad \ldots$

XLIII

XLVIII

$\begin{array}{lllll}\text { White Cedar } & \ldots & \ldots & \ldots & \ldots\end{array}$

XlVII

White Honeysuckle (Plain and Figured)

VI

L-LI

LIX

She Beech...

$\begin{array}{llll} & \cdots & \ldots & \ldots \\ \ldots & \ldots & \ldots & \ldots\end{array}$

$\mathrm{V}$

- White or Cypress Pine

Yellow Cedar

XVII

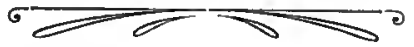




\section{Illustrations in Black and White.}

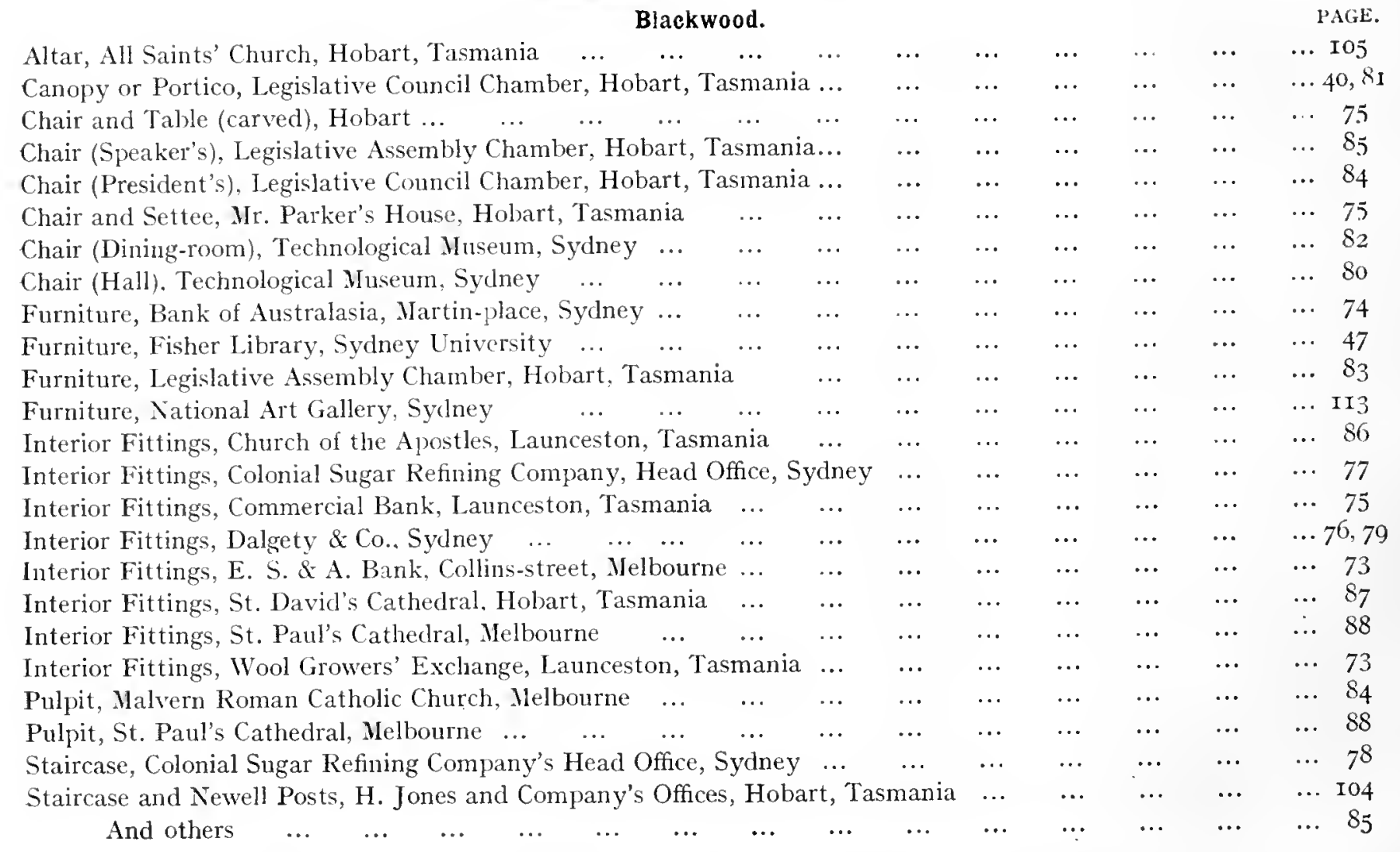




\section{Black Bean.}

Door (Framing only), Technological Museum, Sydney ..

Panel (carved), Technological Nuseum, Sydney ..

Table (carved), Technological Museum, Sydney ...

\section{Brown Pine.}

Columns or Pedestals, Teclnnological II useum, Sydney

\section{Cedar.}

Dado Panelling, Legislative Assembly Chambers, Hobart, Tasmania Dado Panelling, Legislative Council Chambers, Hobart, Tasmania ... Doors, Deputy Town Clerk's Office, Sydney Town Hall Interior Fittings, Council Chamber, Sydney Town Hall Panel (carved), Technological Nuseum, Sydney ...

New South Wales Railway Car (State Governor's), Outside Framing... Roof, Fisher Library, Sydney University. Seats and Organ, St. James' Anglican Church, Sydney Staircase, Royal Society's House, Sydney Staircase, Technological Museum, Sydney Table (Loo), Technological Museum, Sydney Interior Fittings, Camden House, 1834 And others

$\begin{array}{cccc}\ldots & \ldots & \ldots & \ldots \\ \ldots & \ldots & \ldots & \ldots \\ \ldots & \ldots & \ldots & \ldots \\ \ldots & \ldots & \ldots & \ldots \\ \ldots & \ldots & \ldots & \ldots\end{array}$

\section{Celery-top Pine.}

New Soutl Wales Railway Car (State Governor's), Smoke-room Panelling ..

\section{Coachwood.}

Table (made in 1850 ), Camden House, Camden 
Colonial or Hoop Pine.

Interior Fittings, Glebe Presbyterian Church, Sydney ..

Black or Cypress Pine.

Column or Pedestal, Technological Museum, Sydney

\section{Jarrah.}

Exhibit of Karri and Jarrah Company's, Christchurch Exhibition Office Fittings, Furniture and Mantelpiece

Staircase and Hall Fittings

Bed-room, State Governor's Car, New South Wales Railways

Interior Fittings, Bank of New South Wales, Melbourne

\section{Red Bean.}

Four Panels, D.M. Door (Mouldings only), Technological Museum, Sydney ...

\section{Red Mahogany.}

Floor (Margins of), National Art Gallery, Sydney

\section{Red Myrtle (Tasmanian).}

Interior Fittings, Mr. Parker's House, Hobart, Tasmania Stool, and Settee

.. $\cdots$

\section{Rosewood (N.S.W.).}

Settee ...

Table (Queen Anne) 
Chair (Bedroom)

Chair (Carved Glastonbury)

Dining-room, State Governor's Car, New South Wales Railways

Dour (Four-panel D.MI.), Panels only

Doors, Young llen's Christian Association, Sydney

Doors, "Craignish," Macquarie-street, Sydney

Fire Screen ...

Floor, National Art Gallery, Sydney

\section{Spotted Gum.}

Framing, Furniture and Mouldings, Smoke-room, State Governor's Car, New South Wales Railways

\section{A Mountain Ash of N.S.W. and Victoria, Tasmanian Oak, or Stringybark.}

Furniture Ilanufacturing, Coogan's, Launceston, Tasmania

Interior Fittings, All Saints' Church, Hobart, Tasmania

Interior Fittings, Dining-room, Mr. A. Mault's House, Hobart, Tasmania

Interior Fittings, Huon Timber Company's Offices, Hobart, Tasmania

Interior Fittings, H. Jones and Company's Offices, Hobart, Tasmania

Interior of Residence

Interior of St. John's Church, Launceston, Tasmania $\ldots$...

Prie-Dieu, St. John's Church of England, Launceston, Tasmania

Pulpit, Trinity Church, Launceston, Tasmania

Reading Desk, Trinity Church, Launceston, Tasmania ..

Reredos, Fingal Church, Tasmania

And others.

\begin{tabular}{|c|c|c|}
\hline$\ldots$ & $\ldots$ & $\ldots$ \\
\hline$\ldots$ & $\ldots$ & $\ldots$ \\
\hline$\ldots$ & $\ldots$ & $\cdots$ \\
\hline .. & $\cdots$ & $\cdots$ \\
\hline$\cdots$ & $\cdots$ & $\ldots$ \\
\hline$\cdots$ & $\ldots$ & $\ldots$ \\
\hline$\ldots$ & $\ldots$ & $\ldots$ \\
\hline$\cdots$ & $\cdots$ & $\cdots$ \\
\hline$\ldots$ & $\ldots$ & $\cdots$ \\
\hline$\ldots$ & $\cdots$ & $\cdots$ \\
\hline & $\ldots$ & $\cdots$ \\
\hline
\end{tabular}

$\begin{array}{cccc}\ldots & \ldots & \ldots & 99 \\ \ldots & \ldots & \ldots & 105 \\ \ldots & \ldots & \ldots & 104 \\ \ldots & \ldots & \ldots & 103 \\ \ldots & \ldots & \ldots & 104 \\ \ldots & \ldots & \ldots & 103 \\ \ldots & \ldots & \ldots 108-9 \\ \ldots & \ldots & \ldots & 108 \\ \ldots & \ldots & \ldots & 107 \\ \ldots & \ldots & \ldots & 107 \\ \ldots & \ldots & \ldots & 106\end{array}$




\section{Description of each individual Timber, Botany of the Tree, and its Geographical Range.}

NATURAL ORDER.

\section{STERCULIACE $Æ$. \\ \& $\quad$ \& $\quad$ \&}

As a rule this Natural Order in other parts of the world is very poor in its timber production, but one or two of the Australian representatives seem to be an exception in this respect to the rule.

There is one endemic genus, the Tarrictia, which produces hard timbers, and in the case of T.argyrodendron, we have a hard, fairly heavy wood, with a medium specific character. It is known locally as Ironwood or Crowsfoot Elm, and was at one time much more in demand than at present-defective seasoning causing it to be laid aside. It has been used for indoor decoration, and when cut on the quarter shows a very pretty neat figure.

Species Illustrated in Colour :-

Ironwood or Crowsfoot Elm (Tarrietia argyrodendron). 


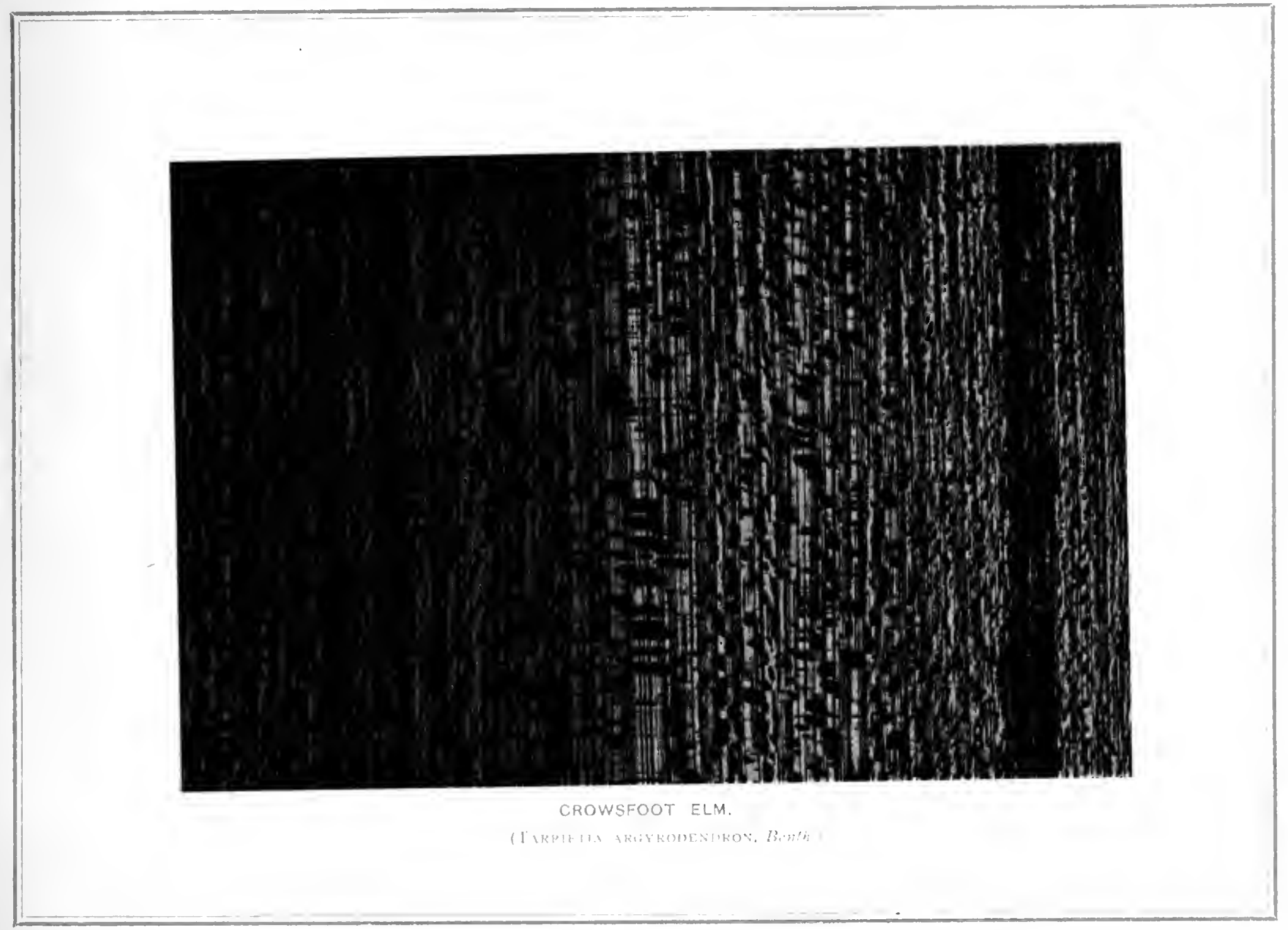




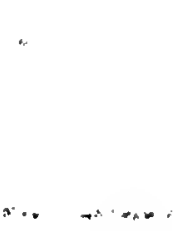

$\therefore \cdot \quad \rightarrow+\infty$

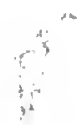

-




\section{Ironwood or Crowsfoot Elm.}

(Tarrietia argyrodendron, Bentham.)

This tree occurs in New South Wales and Queensland, although it is generally regarded as restricted to the latter State where it is more plentiful, and where supplies are generally looked for. The timber should be cut on the quarter if the best figure is to be obtained for cabinet work, and seasoned quickly, as it is liable to deteriorate rapidly if left in the log. Its chief character is a neat, very pretty figure, the medullary rays being numerous and well marked, as seen in the plate here given;-is medium in weight, rather open in the grain, dresses well and takes a good polish. It has been used for interior panelling in some of the Queensland Railway carriages, being suitable for most kinds of inside decorative work, especially railway passenger cars and ships' cabins, also for brush backs, ornamental boxes, turnery, furniture, \&c.

Description of Tree.-A large, erect tree, the stem often exceeding 5 feet in diameter. Leaves trifoliate, the petioles somewhat angular, mostly 2 to 3 inches long. Leaflets lanceolate, from 4 to 7 inches long and from $I$ to 2 inches broad towards the middle, the indumentum more silvery than usual in this genus, but with the same numerous small brown scales. Carpels muricate, oval or globose, $\frac{1}{2}$ to $\frac{3}{4}$ inch long by about $\frac{1}{2}$ inch diameter, furnished with an oblong, oblique, erect wing 2 to 4 inches long by about $I_{4}^{3}$ inches broad, clothed with the same rusty, stellate scales as the under side of the leaves.

Geographical Range.-Coastal districts, from Pine River, Queensland, to Clarence River, New South Wales. 
NATURAL ORDER

\section{TILIACE $\approx$.

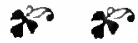

Tine common Lime or Linden of Europe is a well-known tree of this Order, but in Australia its best representatives for cabinet timbers are :-

Maiden's Blush (Echinocarpus australis, Benth.),

Yellow Carabeen (Sloanea Woollsii, F.v.M.),

Blue Fig (Elaocarpus grandis, F.v.M.),

and most of the other Elaocarpus.

Species Illustrated in Colour:-

Maiden's Blush (Echinocarpus australis, Benth.),

Blue Fig (Elcocurpus grandis, F.v.M.). 


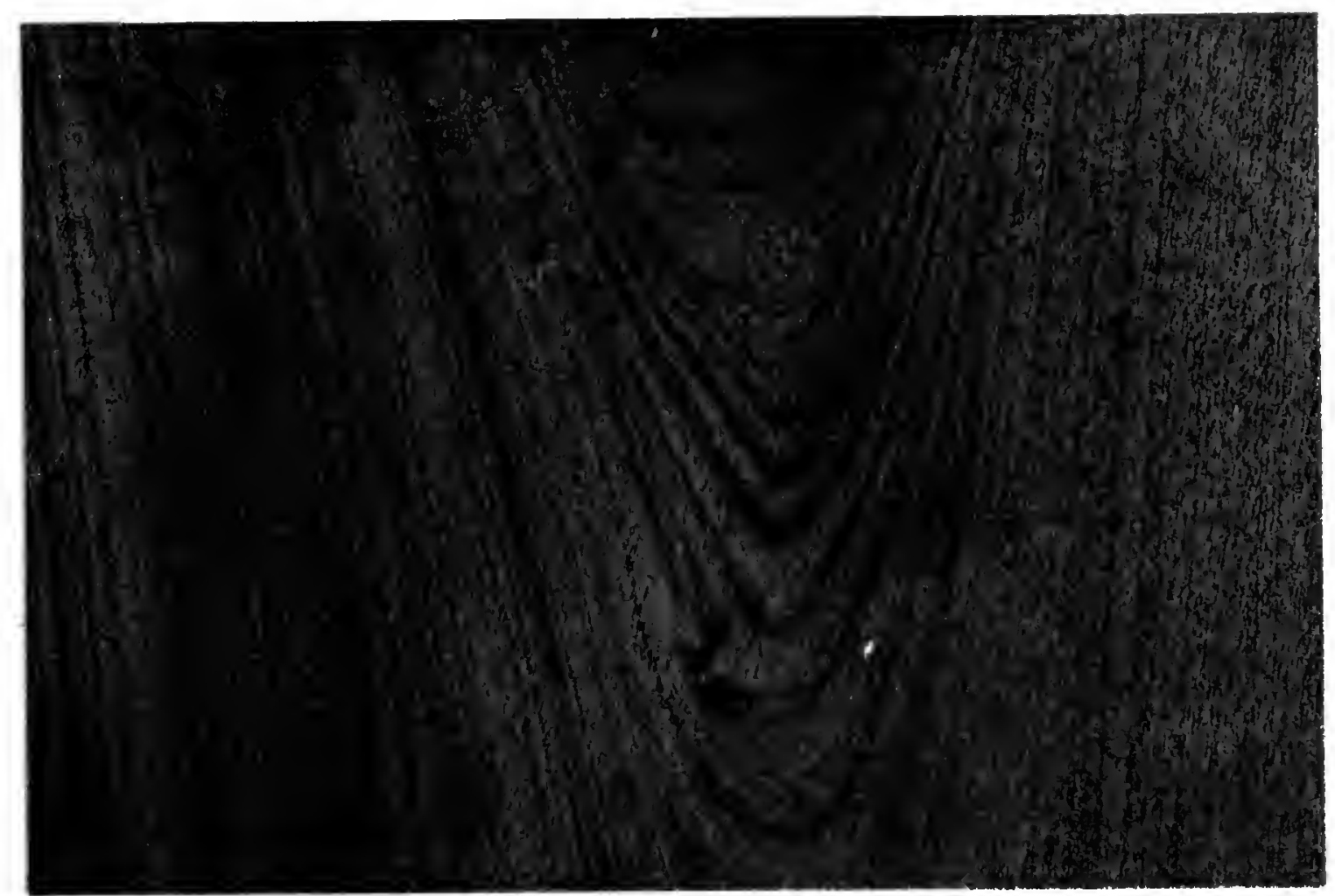

MAIDEN'S BLUSH.

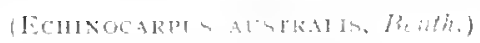




\section{Maiden's Blush.}

\section{(Echinocarpus australis, Benth.)}

This timber is not often seen in the market, although it has certain qualities that recommend it for acceptance in the cabinet line. It has a nice figure, is a warm pink in colour, comparatively soft, easily worked and dressed, and takes a good polish. It could be used for motor-car work on account of its extreme lightness, and is a good wood generally, being suitable for joinery and ornamental purposes, also for planking for small boats.

Description of Tree.-A common tree of the northern and southern brushes of the coast of New South Wales and Queensland respectively, where it attains a height of Ioo feet, and 2 feet or more in diameter. The bark is flat but not smooth. Leaves ovate, acuminate, or obovate, oblong, up to a foot long, paler on the underside, sinuate toothed, narrowed towards the base, but rounded or slightly cordate, coriaceous. Flowers in fairly large axillary or terminal panicles, cernuous, on long slender peduncles. Petals nearly an inch long. Sepals hoary. Capsule thick, woody, echinate, opening into three or four valves about is inch long.

Geographical Range.-Coast district from Queensland to Kiama, New South Wales. 


\section{Blue Fig.}

(Elcoocarpus grandis, F.v.M.)

The vernacular name has been unfortunately chosen, as the tree has no connection with the true figs (Ficus), as shown by the systematic name, the timber of figs being notoriously worthless. In this instance we have a splendid pale coloured, light timber, which shows a sheen on planing. It is open in the grain, dresses well, takes a good polish, is much used in the trade, and can by different stains made to imitate various other timbers. It is used for almost any kind of cabinet and joinery work, also interior fittings of carriages, ships' cabins, \&c. The pale yellow colour would look well in contrast with any of our dark Acacia timbers.

Description of the Tree.-An average tree of the coast brushes, attaining a height of roo feet or more, and a corresponding diameter, having a smooth, yellowish tinted bark, and glabrous in all its parts. Leaves oblong or lanceolate, up to 6 inches long, petiole slightly winged, obtuse or acuminate, shining above, domatia often present, crenulate. Flowers large, in short axillary racemes, sepals about $\frac{1}{2}$ inch long, including the subulate points. Petals of equal length having about five fringed lobes, silky pubescent on the margin towards the base. Anthers pointed. Fruit a drupe, globular, I inch in diameter, of a bluish colour. Inner portion or putamen very hard and wrinkled.

NotE. - It is from the form of fruit that the tree has received its common name.

Geographical Range.-Coast district of Queensland, from Pine River to Northern New South Wales. 


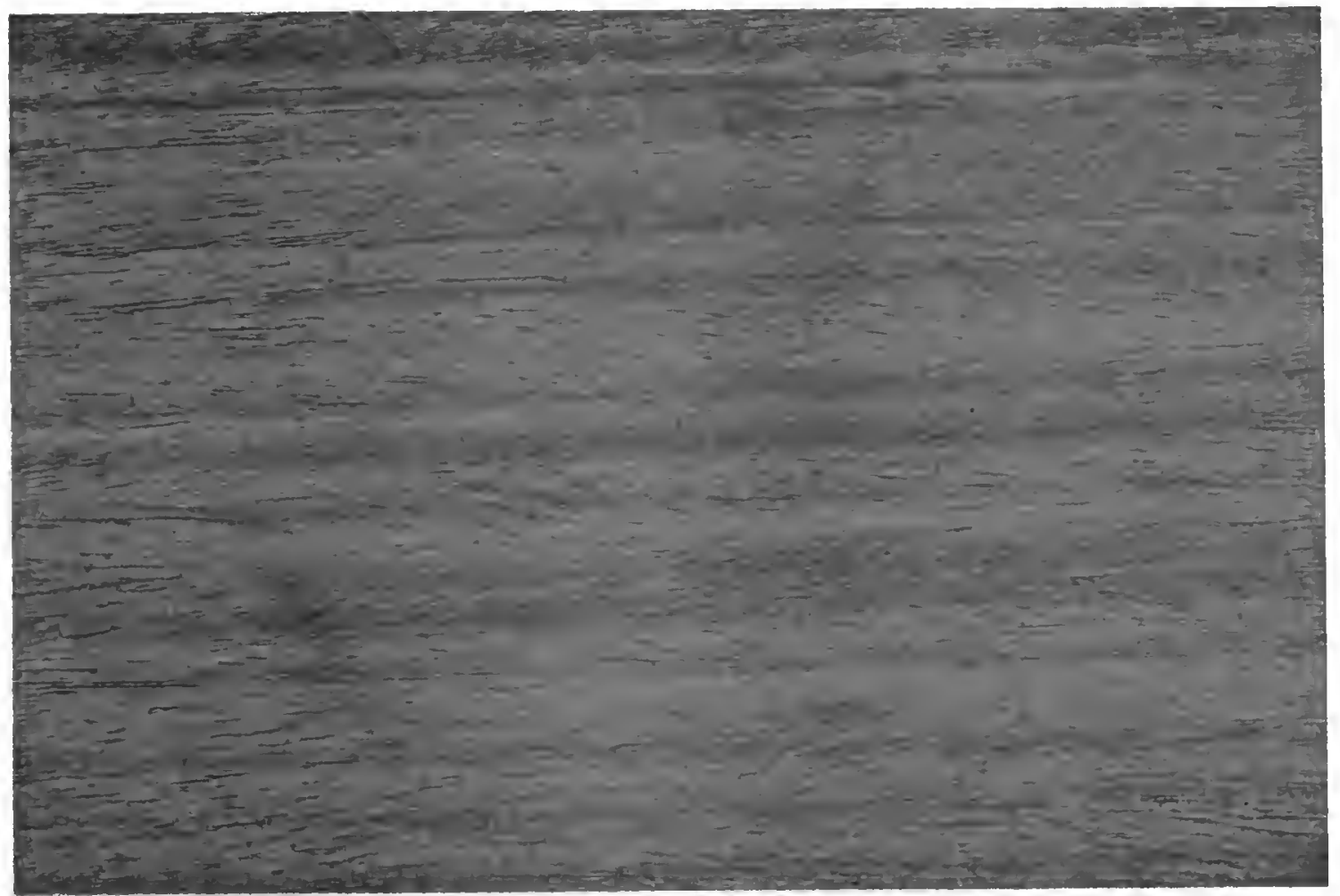

BLUE FIG.

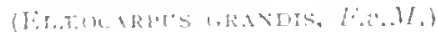



NATURAL ORDER.

\section{RUTACE E. \\ * $x$}

THIs natural Order is quite southern in its distribution, and as a timber yielder is not famous out of Australia. The material obtained from our Rutacere is deserving of far more attention than has yet been given it. The genera Bosistoa, Melicope, Pentaceras, Evodia, and Zanthoxylum produce beautiful pale yellow-coloured or even whitish timbers. It is to be regretted that groups of such fine woods should be so near extinction. Two are photographed here, as the others are now less frequently found on the market. These particular illustrations will give the index to the rest of the Rutaceæ timbers, which are generally of medium weight, close grained, polish and dress well. and would be an acquisition in many branches of cabinet work.

Species Illustrated in Colovr:-

Thorny Yellow Wood (Zanthoxylum brachyacanthum, F.v.M.).

Scrub Hickory (Pentaceras australis, J. Hook.). 


\section{Thorny Yellow Wood.}

(Zanthoxylum brachyacanthum, F.v.M.)

This is a species that is not usually found in the market owing to its rarity, but deserves. attention amongst foresters as a forest tree for propagation. The timber has a canary yellow colour, is hard, close grained, dresses and seasons well, is fairly heavy, and takes a good polish. It is strong and durable, with an attractive colour, and would be useful for any small article of furniture or ornamental work where these qualities are required. It could also be used for fancy and ornamental articles such as ladies' jewellery caskets, \&c.

Description of the Tree.-A brush tree of average dimensions, the bark on the trunk and branches being covered with short conical thorns. Leaves alternate pinnate, the common petiole being sometimes a foot long, leaflets nine to thirteen, opposite petiolate, shining, almost membraneous, sometimes serrulate or crenate, shining, 2 to 3 inches long, ovate to oblong elliptical, glabrous. Flowers in short axillary panicles, the male flowers nearly 3 lines long, the female ones shorter. Fruit, one to five distinct cells, dry or drupaceous, usually two-valved.

Geographical Range.-Brush forests, Southern Ranges, Queensland to Clarence River, New South Wales. 


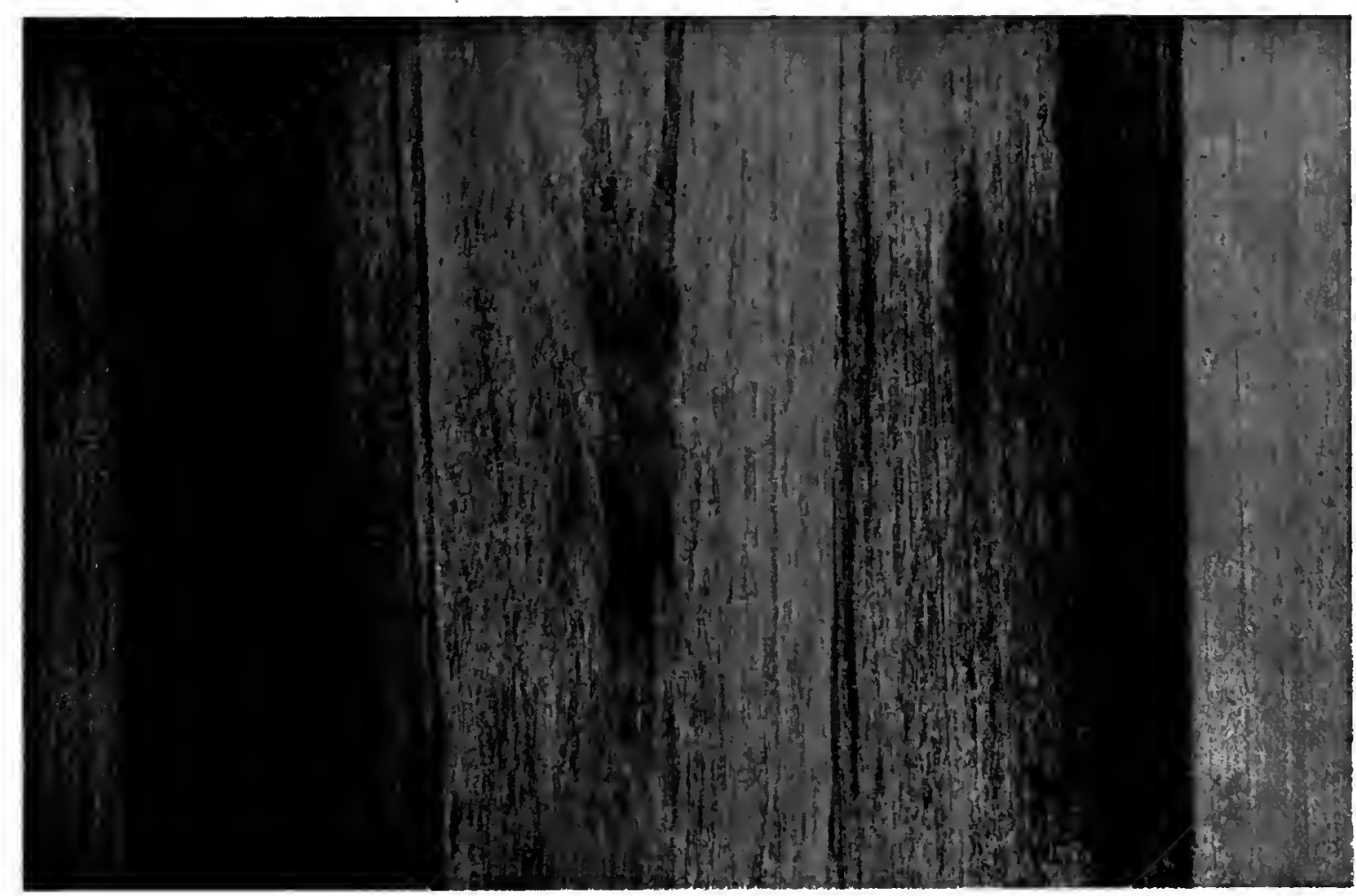

THORNY YELLOW WOOD.

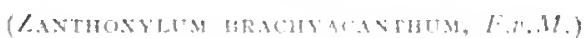




\section{$-$}




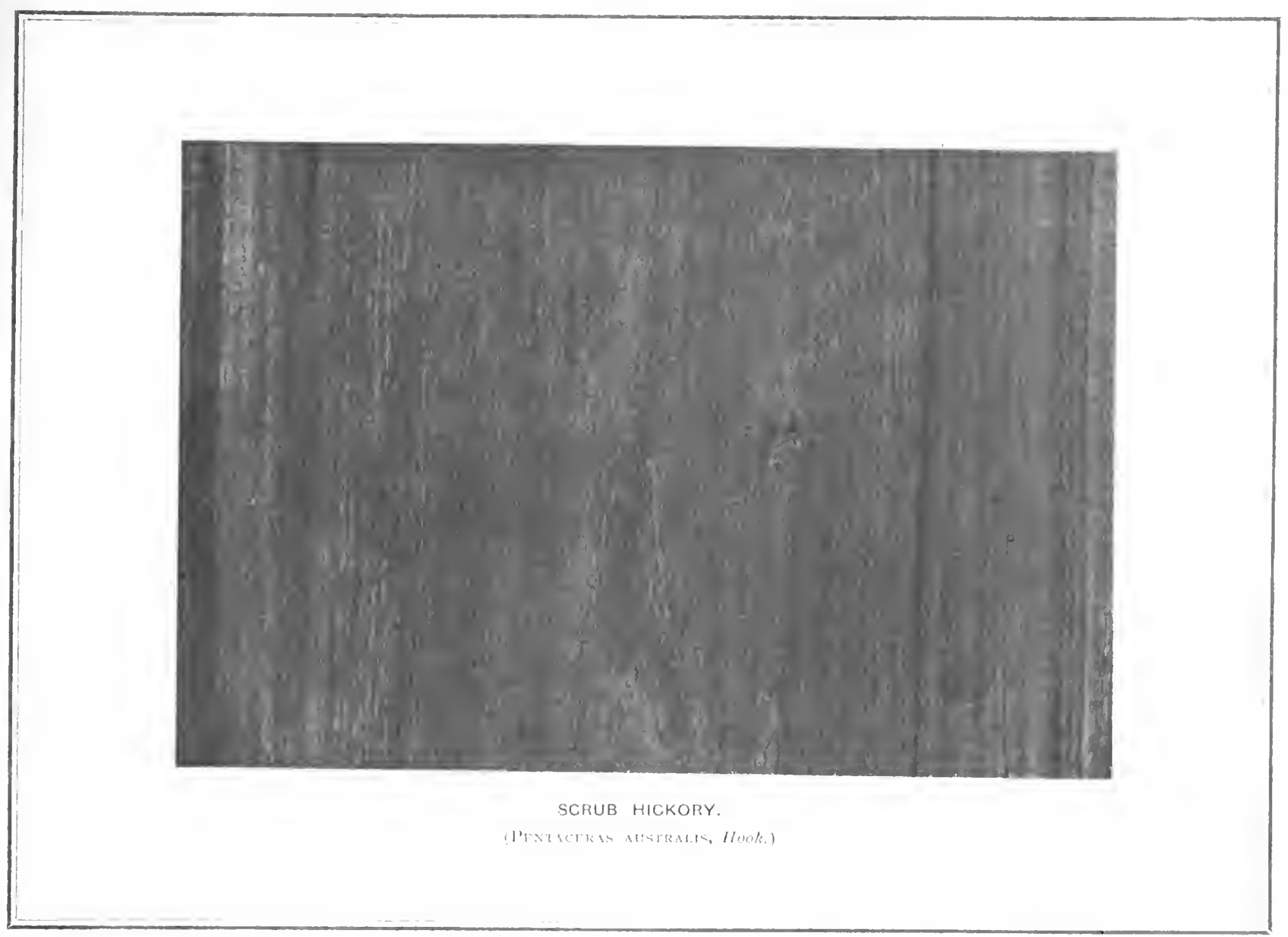





\section{Scrub Hickory.}

(Pentaceras australis, J. Hooker.)

In some respects this might be regarded as a good substitute for English Hornbeam, both in colour and texture, although it has a better figure. The tree grows to a fair average size, and so produces a timber of sufficient dimensions for cabinet work. It is hard, close grained, pale yellowish in colour, dresses well and takes a fine polish, which brings out a natural sheen not shown by planing. It would make elegant furniture in light coloured suites, and look well in panelling. It is in fact suitable for any class of cabinet work where strength and durability are required combined with an attractive appearance. It is strongly recommended for forest culture.

Description of the Tree.-A medium-sized tree of the scrub of the middle eastern coast districts of the continent. Leaves pale on the underside, pinnate, with a petiole ranging in length up to a foot; leaflets from six to twelve, in opposite pairs, and a teiminal one, ovate to lanceolate. obtuse or acuminate, up to 6 inches long, edges entire, rarely finely crenate, sometimes decurrent on the lower edge. Flowers in large panicles on the ultimate branches. often exceding the leaves. Petals and stamens very small. Fruit a samara, I to 2 inches long, up to 3 inch broad.

Geographical Range.-Brush forests, Brisbane River, Queensland to Richmond - River, New South Wales. 
NATURAL ORDER.

\section{MELIACE $\nRightarrow$.}

$x \quad x$

This Order is fairly well distributed in the tropical and sub-tropical regions of the world, and commercially might be called the Mahogany order, for from it the famous Mahoganies of commerce are derived, and in this connection one has only to mention Honduras Mahogany, Honduras Cedar, Indian Satin-wood and Red Cedar of Austraiia, to bring to mind some of its contributions to the cabinet timbers in general. Its principal Australian cabinet timbers are :-

White Cedar (Melia Azelarach, Linn.).

Rosewood (Dysoxylon Fraseriantm, F.v.M.).

Red Bean (D. Muelleri, F.v.M.).

A Pencil Cedar (D. rufum, Benth.).

A " Rosewood" (Synoum glandulosum, A. Juss.).

Grewia (Orenia acidula, F.v.M.).
Onion Wood (Owenia cepiodora, F.v.M.).

(Carafa moluccensis, Lam.).

Red Cedar (Cedrela Toona, Roxb.).

Long Jack (Flindersia Oxleyana, F.v.Ml.).

Queensland Maple ( $F$. Chatawaiana, Bail.).

(Flindersia, spl.).

SPECies Illustrated in Colour:-

White Cedar (Melia Azedarach, Linn).

Rosewood (Dysoxylon Fraserianum, F.v.M.).

Red Bean (D. Muelleri, F.v.M.).
Red Cedar (Cedrela Toona, Roxb.).

Long Jack (Flindersia Oxleyana, F.v..H.).

Queensland Maple (F. Chatawaiana, Bail.). 


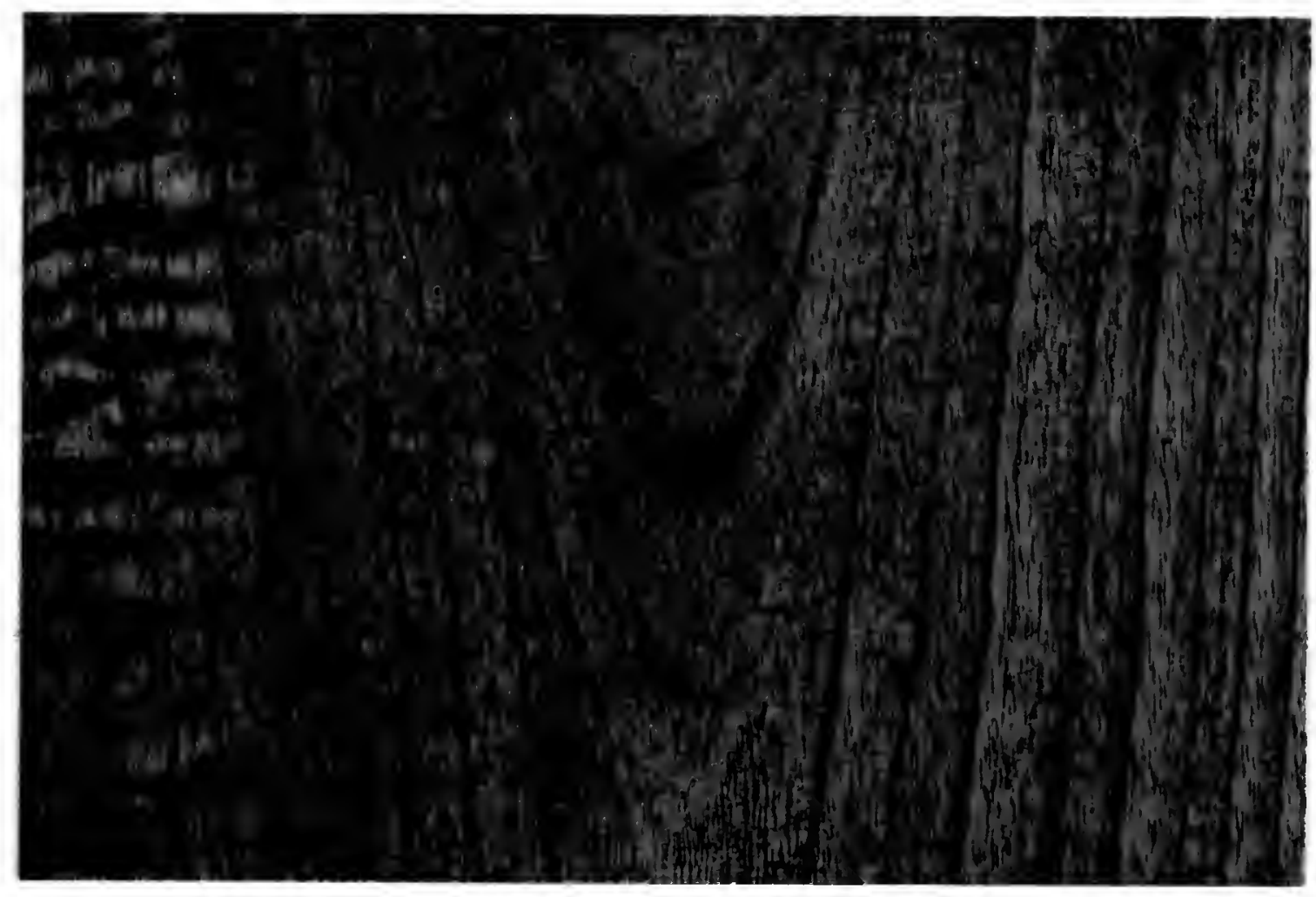

WHITE CEDAR.

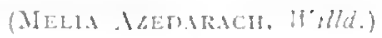




\title{
White Cedar.
}

\author{
(Melia Azedarach, Lim.)
}

This wood is light in colour and weight, and has a figure and texture not at all unlike English "Elm" (Ulmus campestris). It is open in the grain, has large annual rings, is very easy to work, and known in the trade as Golden Cedar as well as White Cedar. It is useci for cabinet work, veneering, turnery, \&c., and any kind of inside joinery, but is not suitable where it is exposed to climatic changes.

Description of the Tree.-A large forest tree of the coast brush lands, and now found in cultivation, as the long pendulons pinnate leaves (decichous) give it quite an ornamental appearance. Bark hard, compact, distinctly ridged or checkered. I-caflets opposite, mostly coarsely lobed or toothed, ovate to lanceolate, I to 2 inclies long. Flowers lilac-coloured, in fairly large. loose panicles, but shorter than the leaves, covered with a mealy tomentum. Scpals small, petals nearly $\frac{1}{2}$ inch long. Staminal tube hirsute inside belnind the anthers, ten to twelve-teeth. Fruit a white drupe, ovoid o" nearly globular.

Geographical Range.-Lik: most of our cabinet timbers it is found in the middle area of the East Coast districts of the continent in the brushes. 


\title{
Rosewood.
}

\author{
Dysoxylon Fraserianum, Bentham.)
}

This tree, like its other congeners, flourishes in the brushes, and is still fairly plentiful. The wood has been extensively employed in furniture manufacture, and is so to an extent now, although it has a serious drawback in some specimens in that it " sweats," to use a trade expression. It would be a distinct gain if this objection could be removed, for it would add an otherwise most valuable addition to our cabinet timbers. It has a pleasing rech colour, although too light for some tastes, but is often considerably dark stained when made into furniture.' It p'anes well, is easily worked, light in weight, and fairly hard. The texture is closer than Red Bean or Cedar, and in this character more approaches the Queensland Iaple.

Description of the Tree.-One of the tallest trees of the Cuast brush lands, attaining a height of 200 feet, with a thin, yellowish, flaky-or tessellated bark. Leaflets five to nine, oblong, lanceolate or ulliptical, acuminate, 3 to 6 inches long, narrowed and equal at the base. Domatia often present on the underside. Flowers in short panicles in the upper axils, hose, divaricately branched, slightly pulescent. Calyx cupular, very small, shortly and broadly four-lobed. Petals four, abont it inch long; staminal tube eighttoothed, glabrous. Fruit a globular or pear-shaped cajsule, opening loculicidally in three to five thickly coriaceous raties.

Grographical Range.-This is essentially a brush timber of the North Coast of New South Wales and the South Coast of Queenstand. 


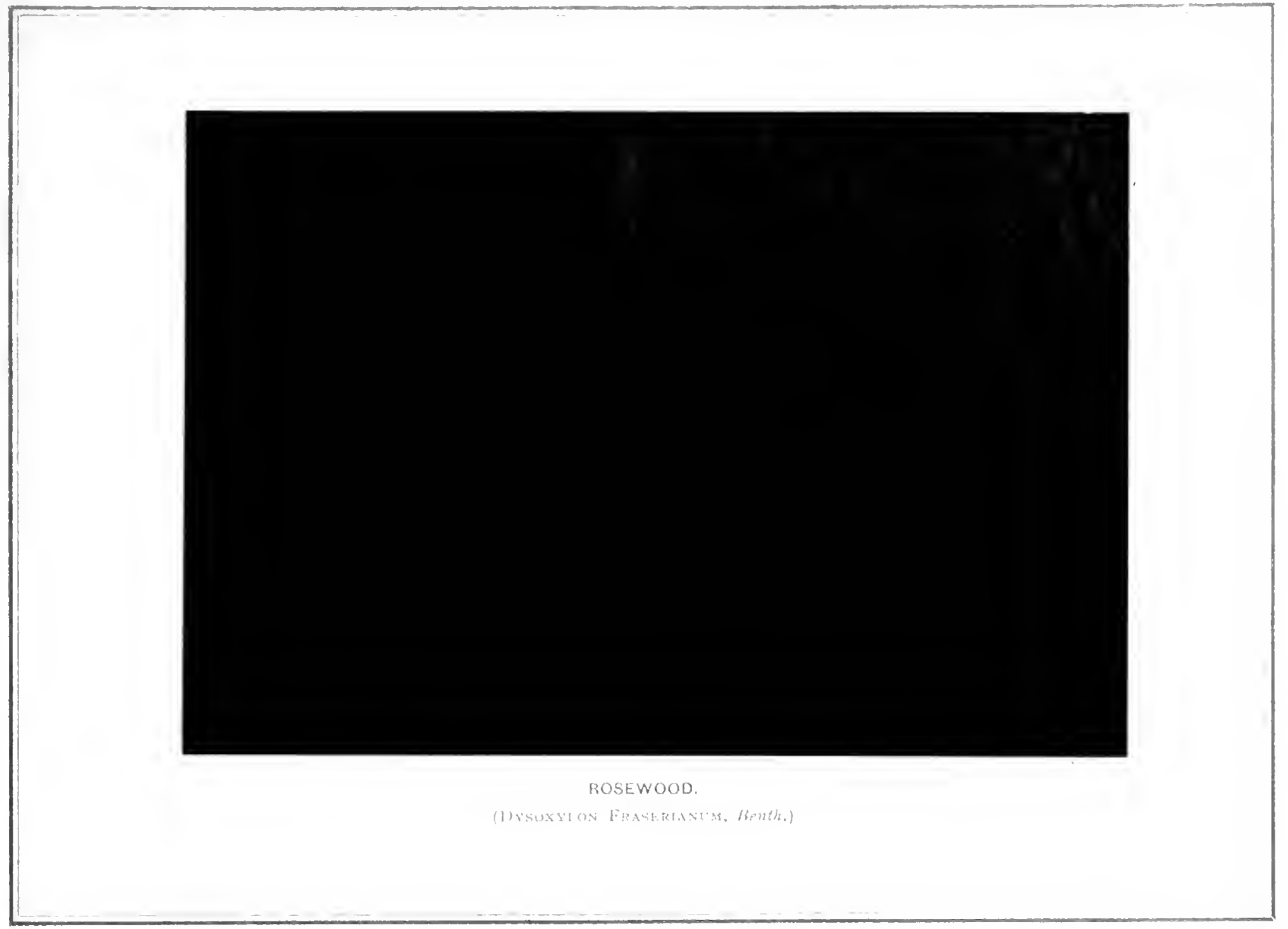


$\frac{116804}{11}$ 


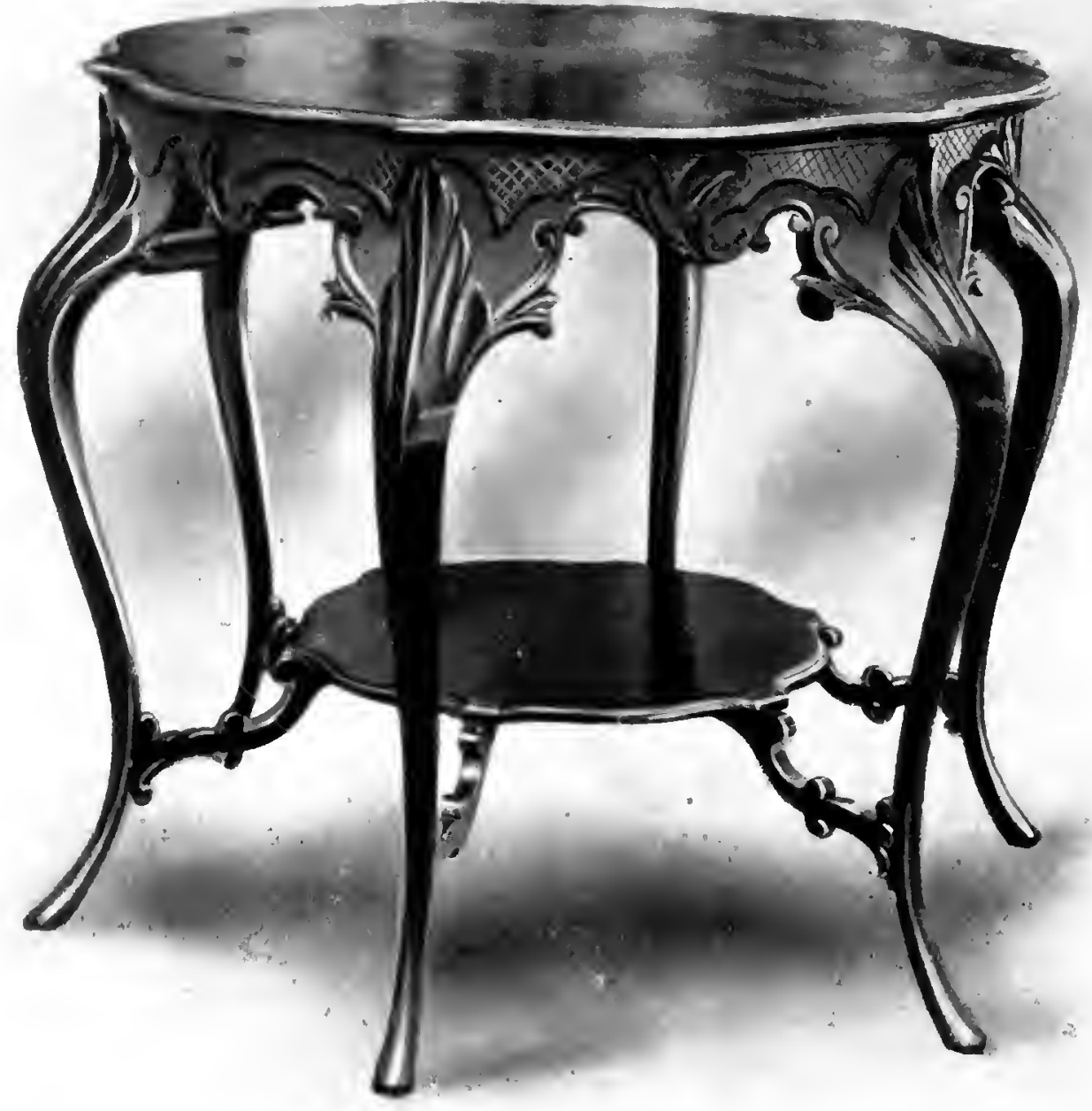

Rosewood. 


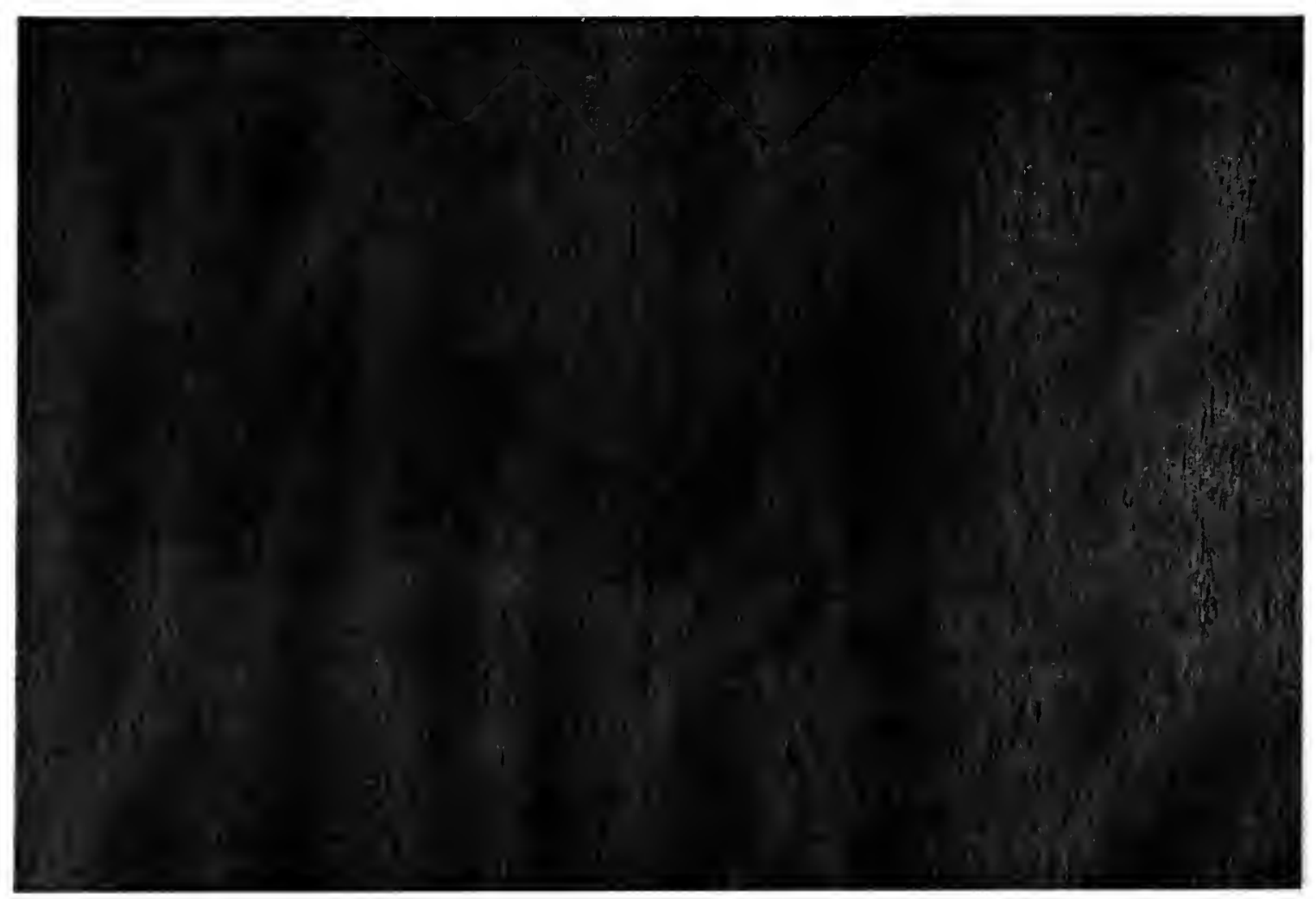

FED BEAN. (L gheer shado

Juw 


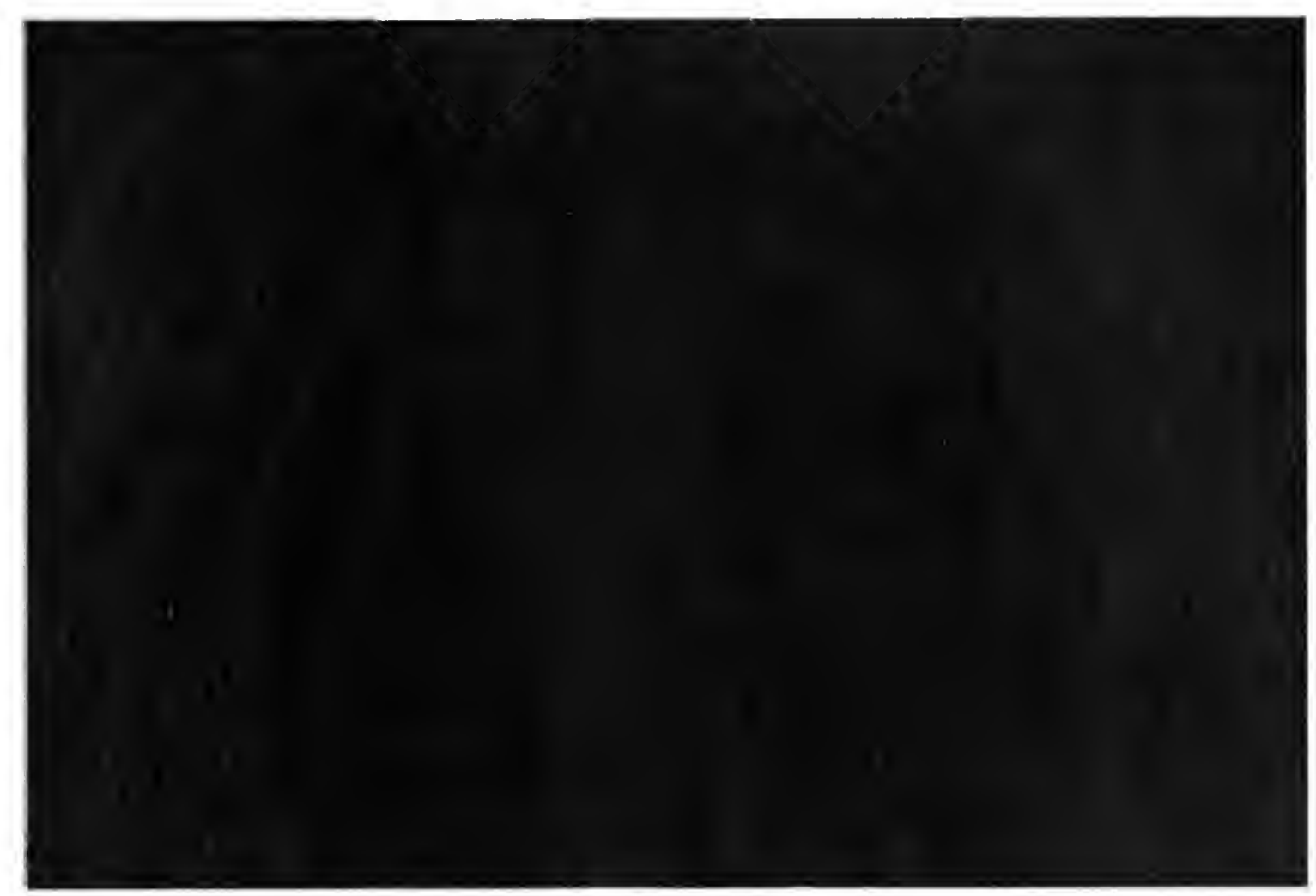

BED EEAN. Very dark.

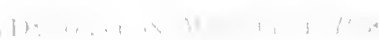




\section{Red Bean.}

\section{(Dysoxylon Muclleri, Benth.)}

It is not now one of the best known or most used timbers in the cabinet trade, although possessing many qualities obtaining in this branch of commerce, and was much more appreciated a decade or two ago than it is to-day. The colour is very attractive, being of a warm red character when freshly cut, but becomes lighter in season'ng, and takes a splendid polish. It is casy to work, slightly open in the grain and often has a decorative figure, which places it well in the front rank of red timbers for cabinet work, for which it is most suitable. It is heavier and stronger than cedar, and could be utilised for almost any purpose for which cedar is used.

Description of the Tree.-like its congener, D. Fraserianum (Rosewood), it is one of the grants of the Coast brush lands, and probably measures 200 feet in height, with a proportionate diameter, and a thin, dark yellow flaky bark. It is, however, larger in all its parts than that tree. Leaves $I$ to 2 feet long; leaflets eleven to twenty-one, from ovate to almost lanceolate, shortly acuminate, 3 to 6 inches long, very oblique at the base. Flowers numerous, in much branched pyramidal panicles, 9 inches to I foot long. Sepals and petals similar to D. Froserianum. Tubular disk long and slender.

Geographical Range.-This tree occurs in the northern brushes of New South Wales and the southern brushes of Queensland. 


\section{Onion Wood.}

(Orenia cepiodora, F.v.ll.)

A good all romd cabinet timber such as this, certainly deserves a better common name, for of all the specimens that have come under my notice, in no instance has an alliaceous odour been detected when seasoned. It has the general facies of the Meliaccous timbers, being reddish in colour, soft, easily worked and dressed, and takes a good polish. It is suitable for all kinds of cabinet work, such as counters, wainscotting, furniture, doors, panelling, in fact, anything in the cabinet line. It is very similar to Red Cedar, but slightly heavier and closer in the grain.

Deseription of the Tree.-A large brush tree with large pinnate leaves. Leaves sometimes measuring 2 feet in length, oblique, thin, shining. with oblong-lanceolate leaflets 5 to 6 inches long. numbering up to twenty. Flowers small, in broad axillary panicles, about a foot long. Fruit a globular drupe with a rugose putamen, rose coloured, under I inch in diameter.

Geographical Range.-Sonthern Coast districts of Queensland to Richmond River, New South Wales. 


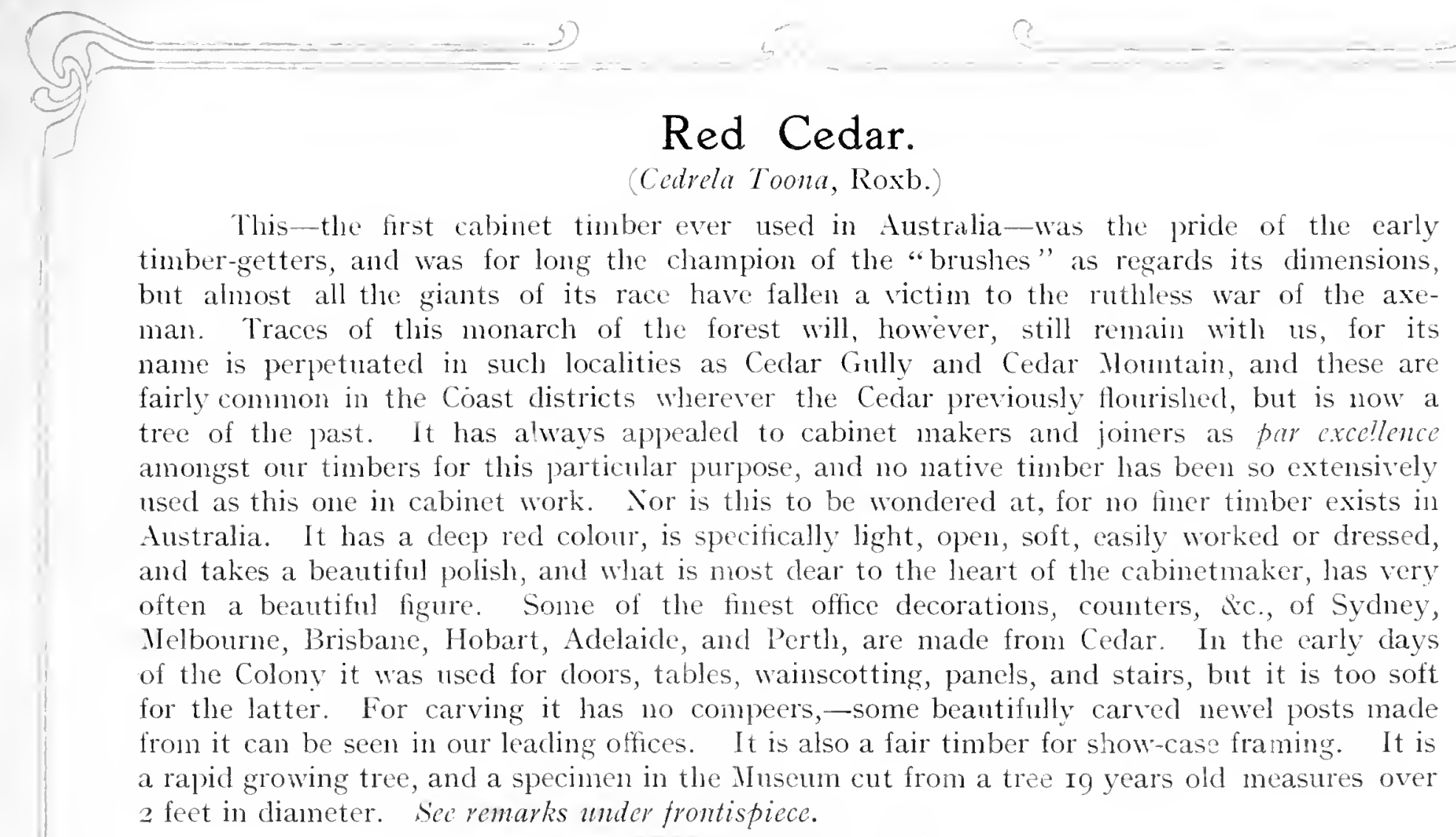

Description of the Tree.-A giant, if not the giant, tree of the Australian lrushes. It is essentially a brush and gully tree. Leaves pinnate, large, deciduous: leaflets eleven to seventeen, opposite, irregularly alternate, lanceolate oblique, up to 5 inches long, pale underneath, thin. Flowers in a large, many-flowered pyramidal panicle, glabrous. Sepals orbicular, ciliate, very small. Petals white or pinkish, under inch long. Fruit a capsule, glabrous, oblong, I to $I_{2}^{\frac{1}{2}}$ inches long.

Geographical Range.-It occurs in the brushes of the east Coast of Australia, ahmost as far south as the Victorian border. 

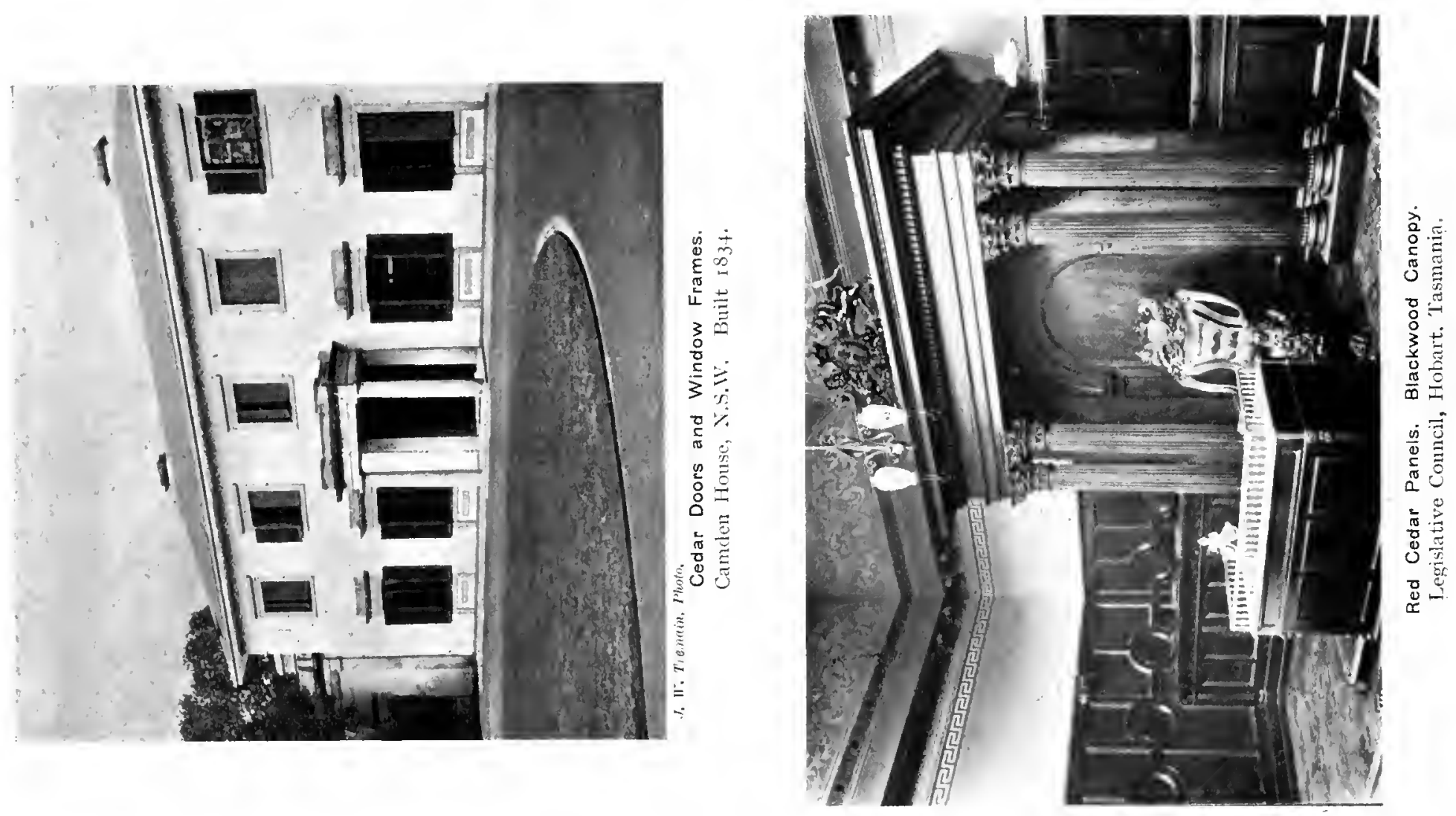


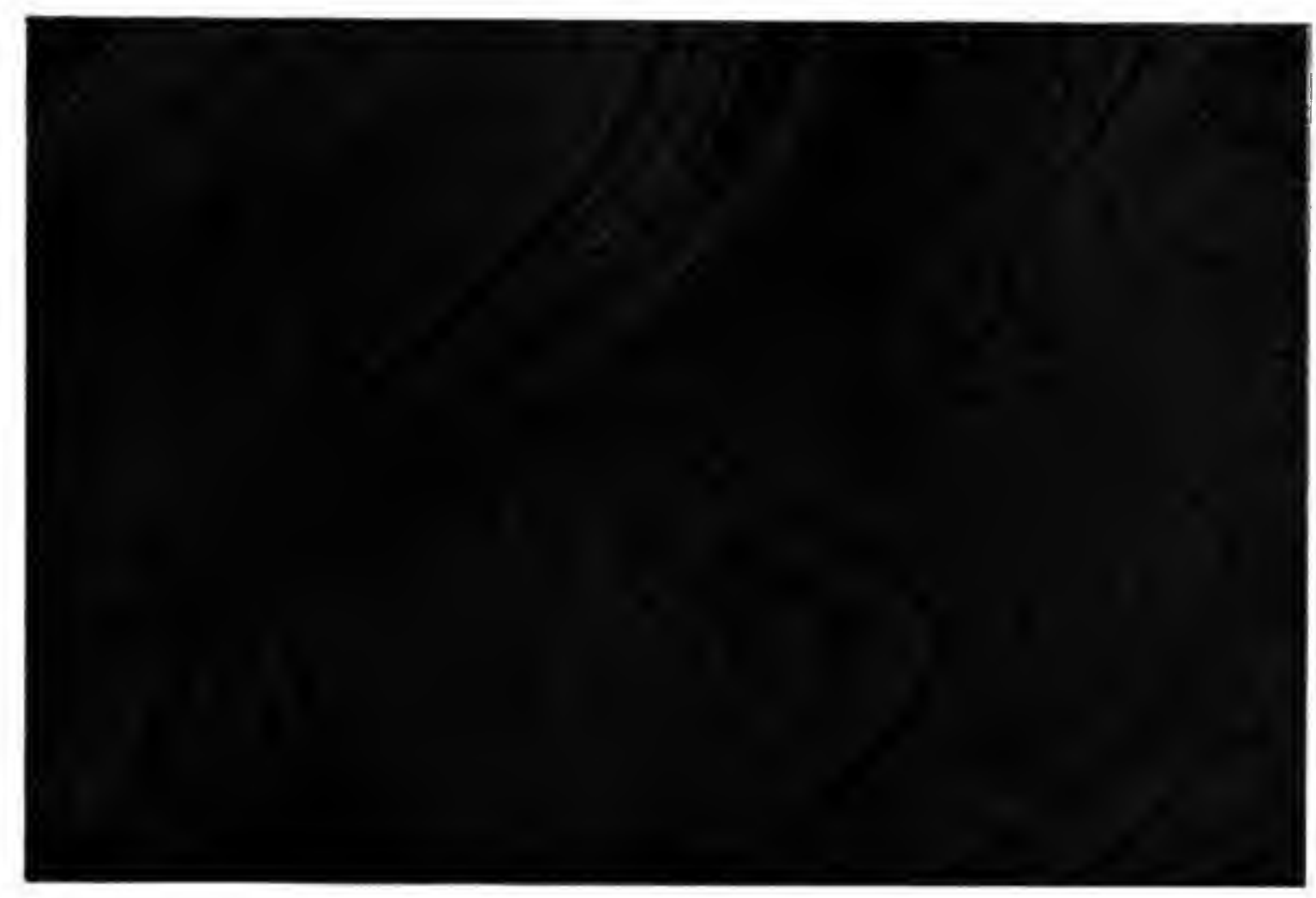




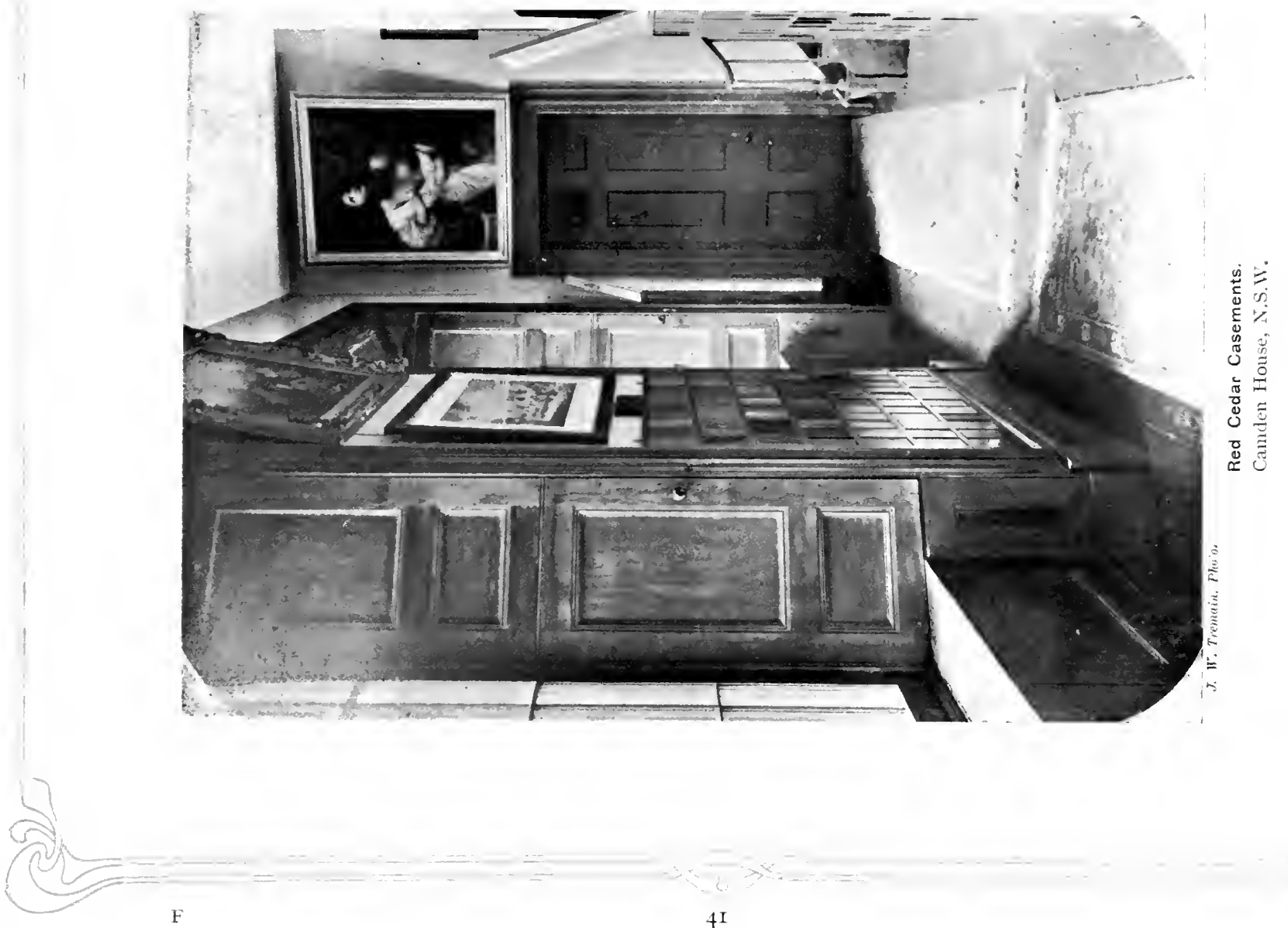


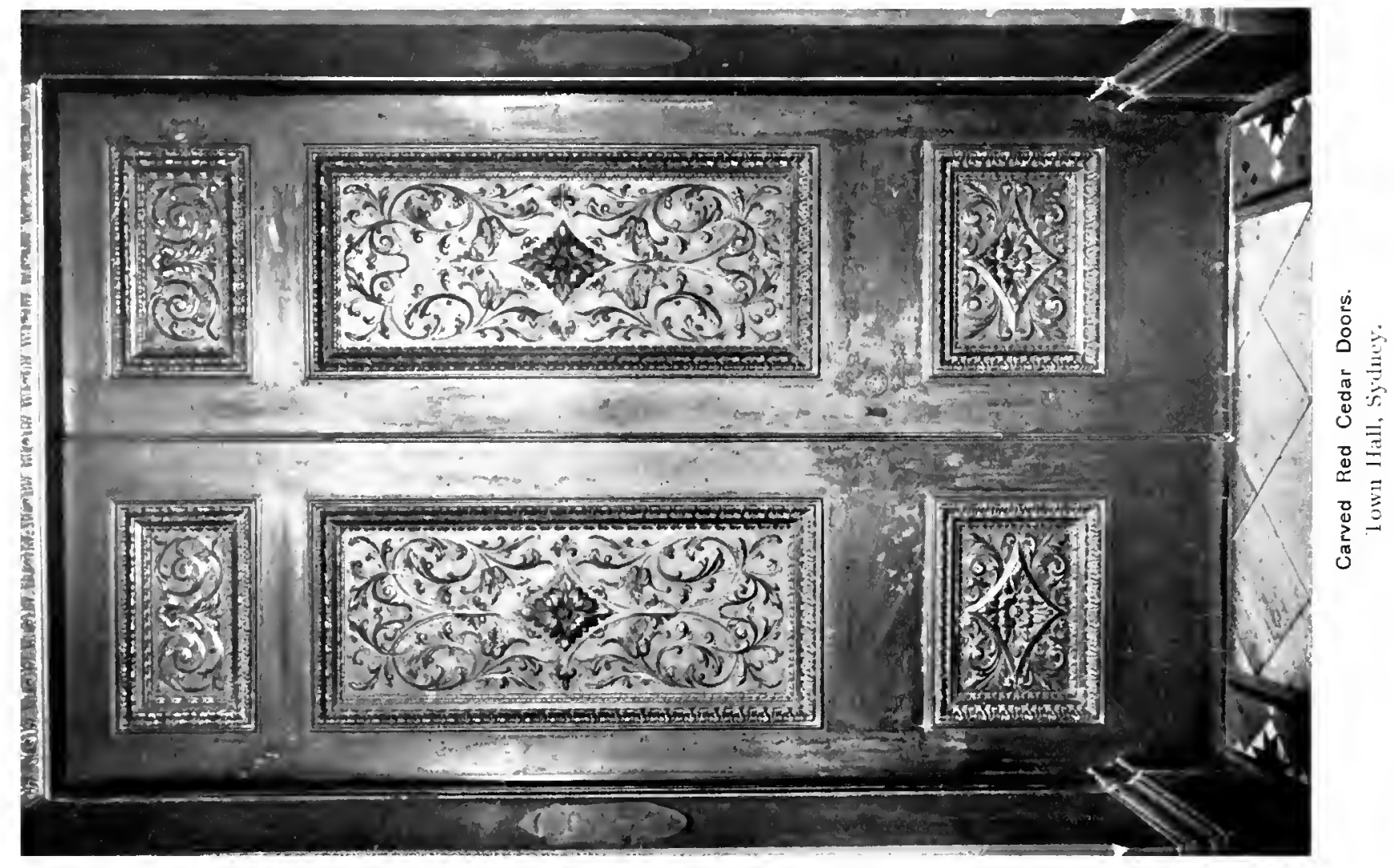




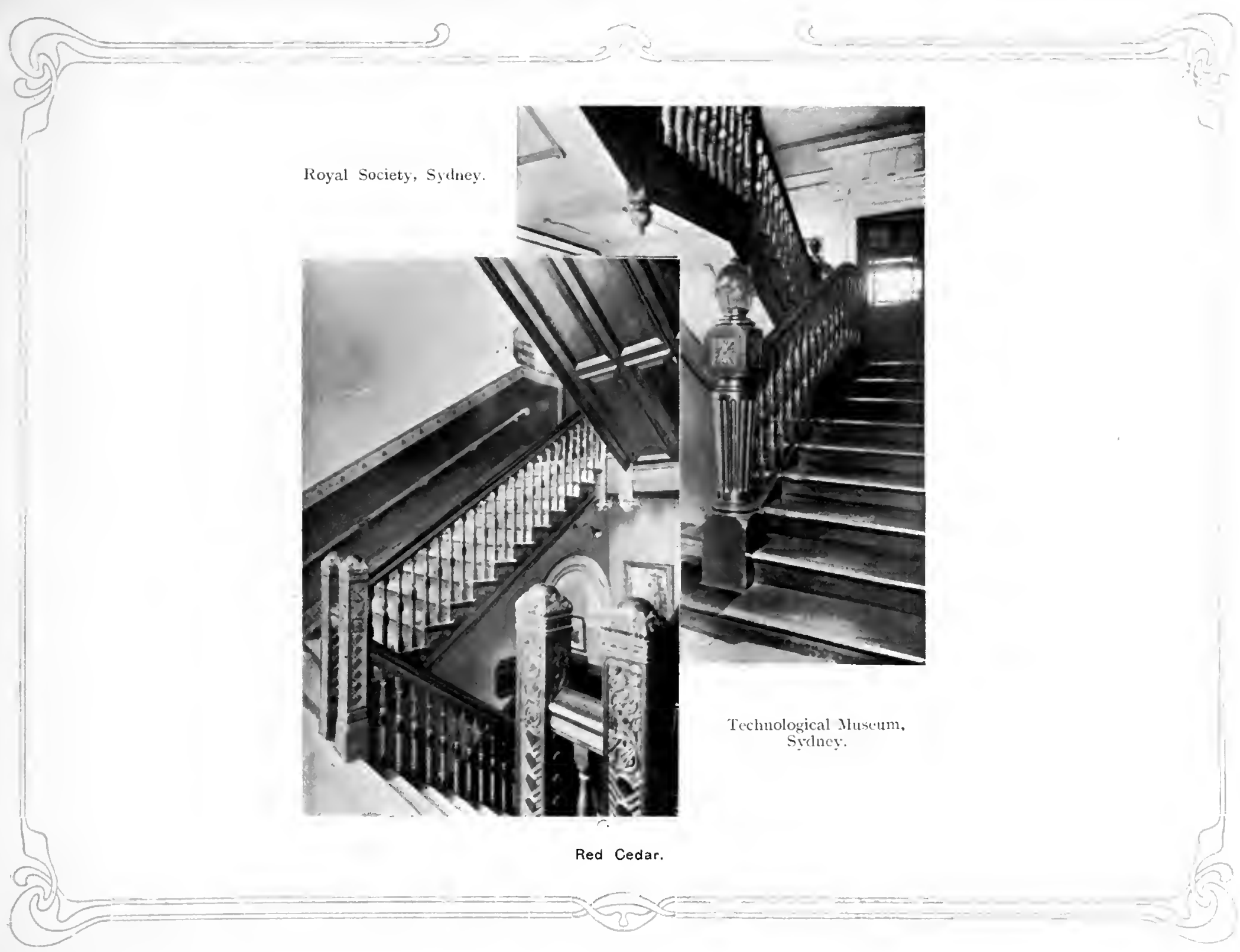




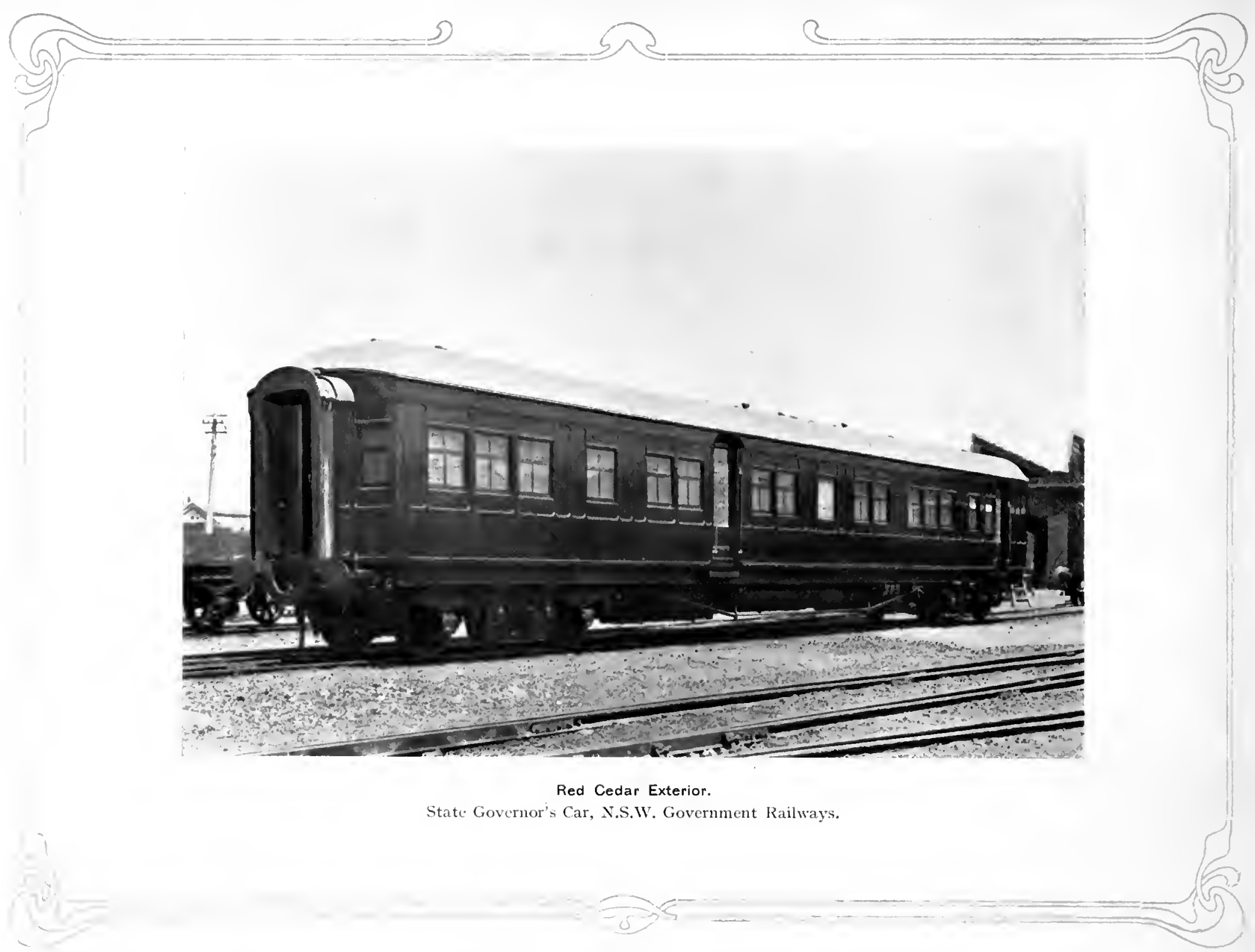




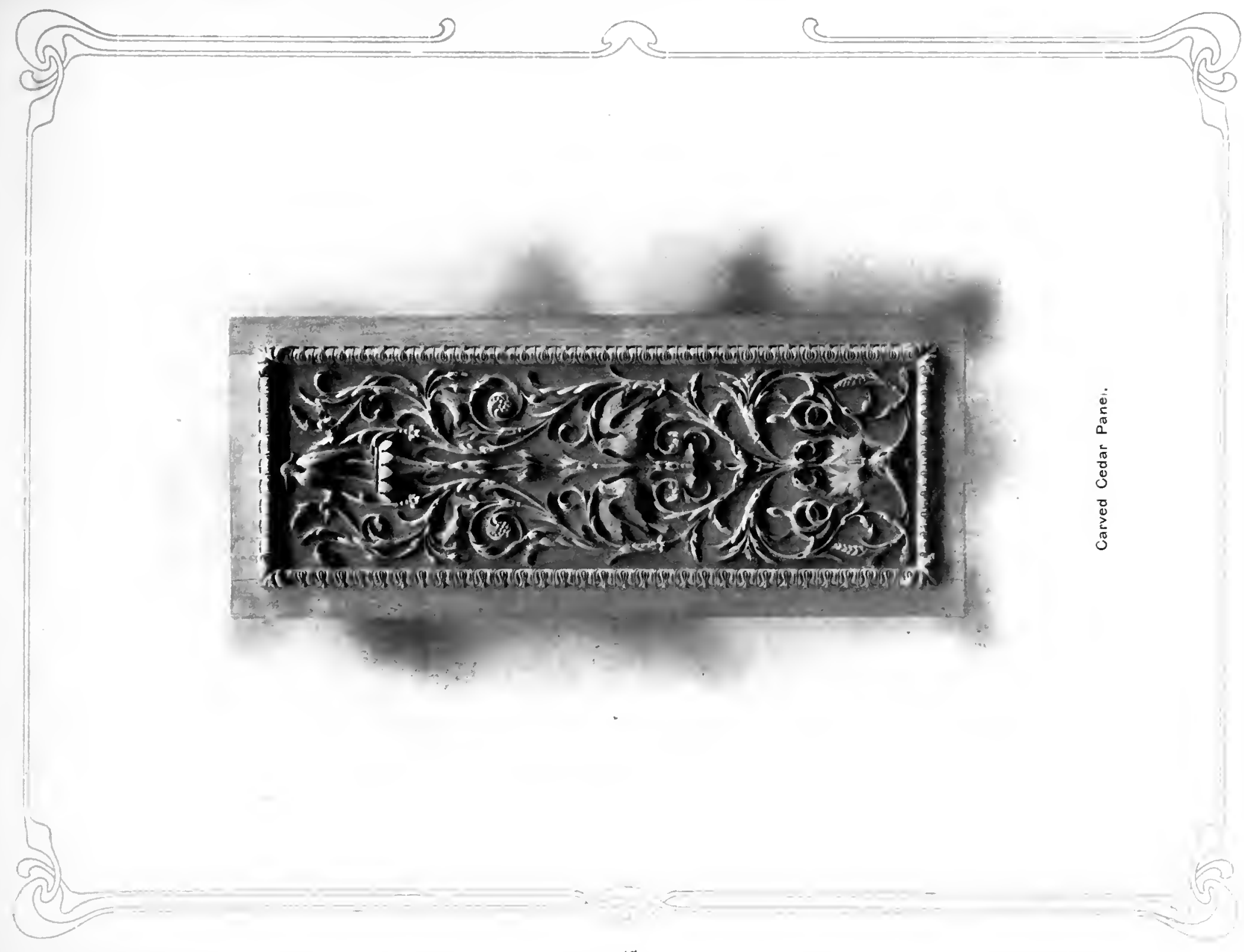




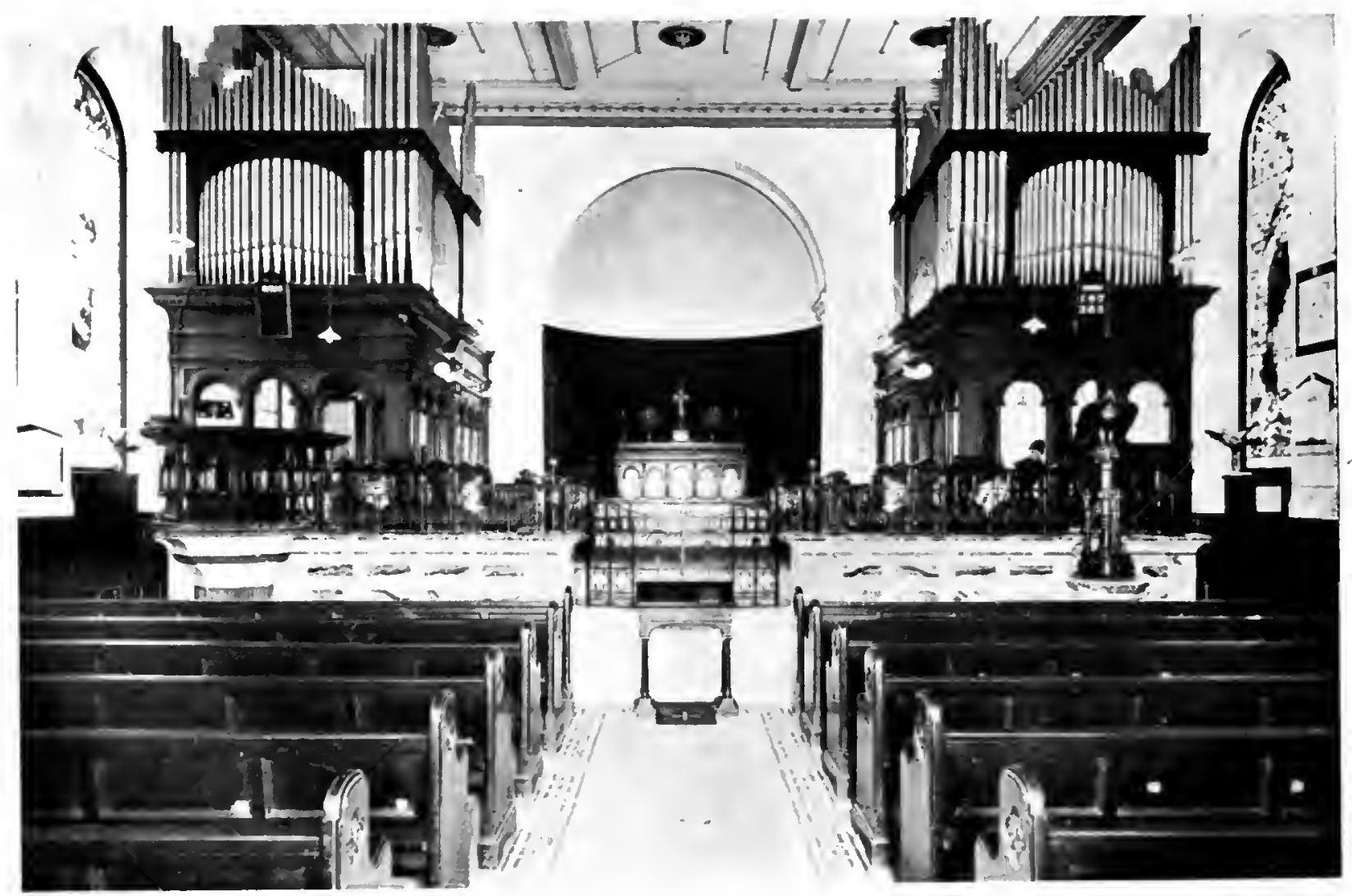

Red Cedar Seats and Organ.

St. James' Church, Sydney. 


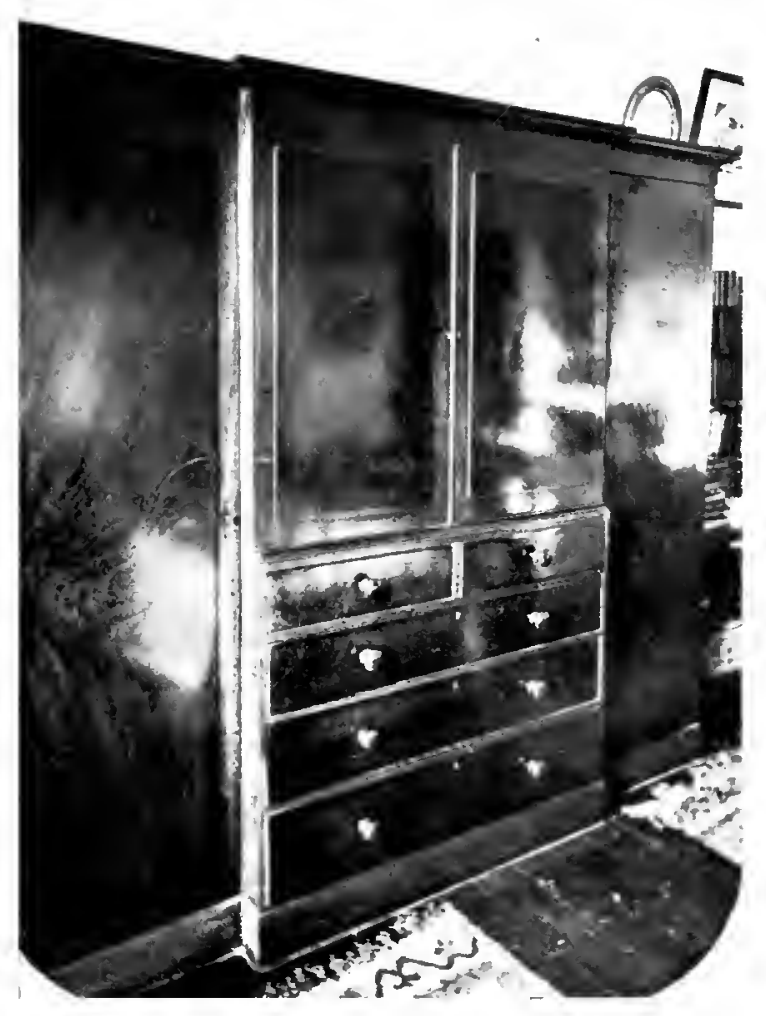

Red Cedar Wardrobe.

Camilen House, N.S.W. 1834 .

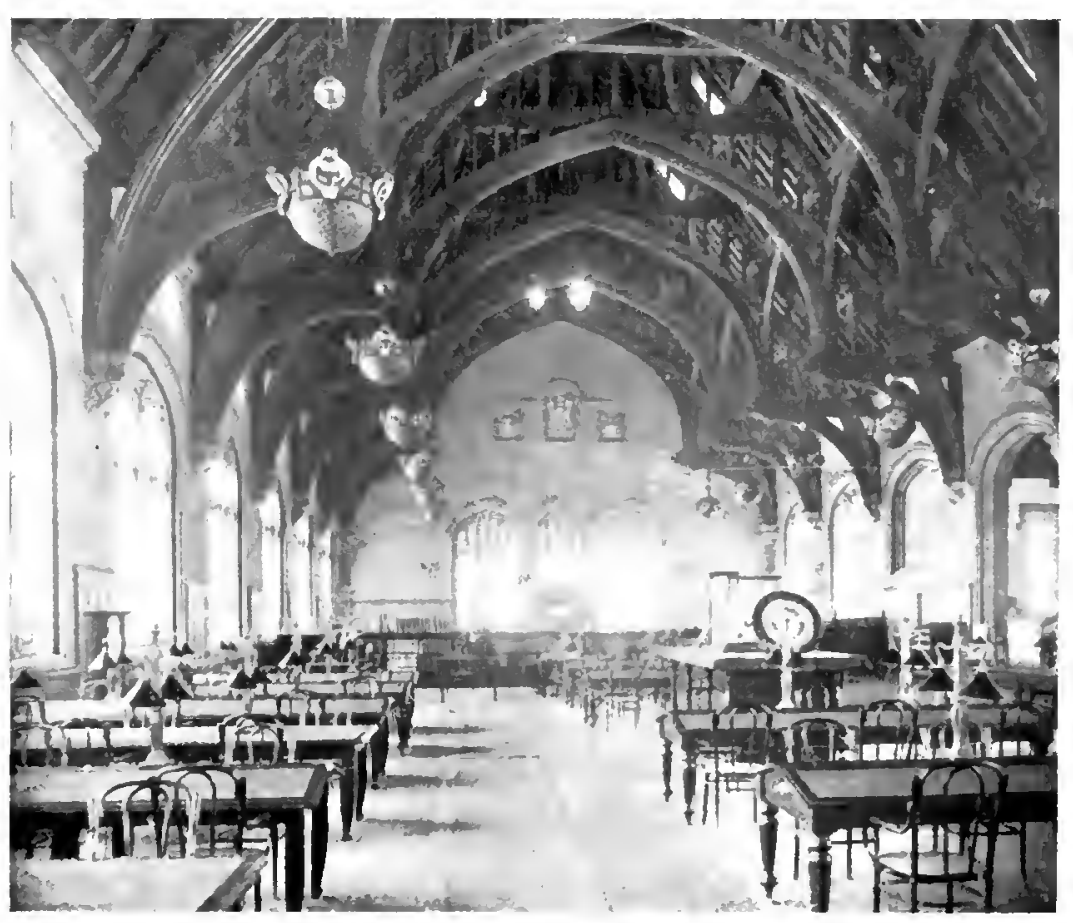

Red Cedar Roof and Blackwood "Furniture.

Fisher Library. University. Syclney. 


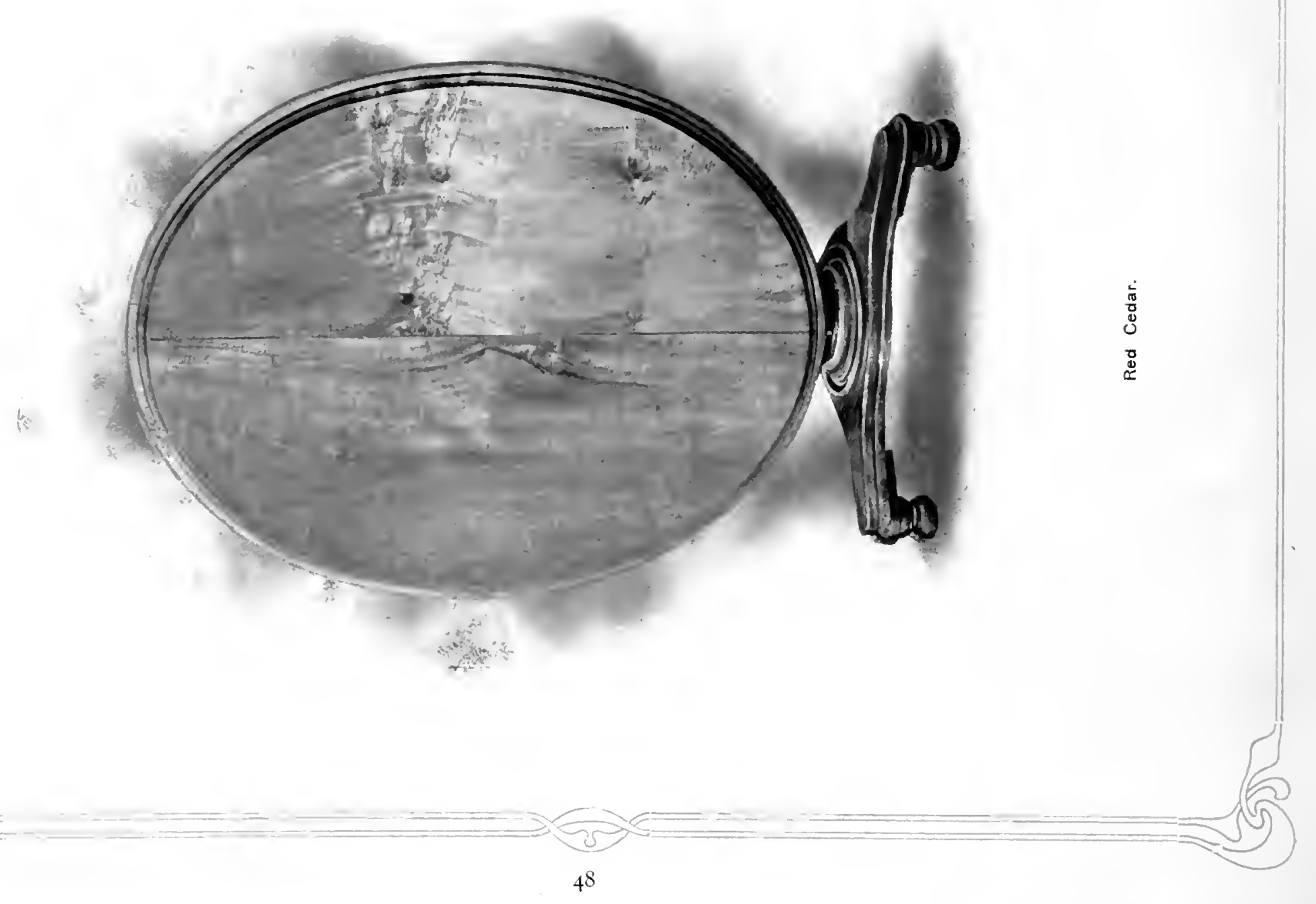




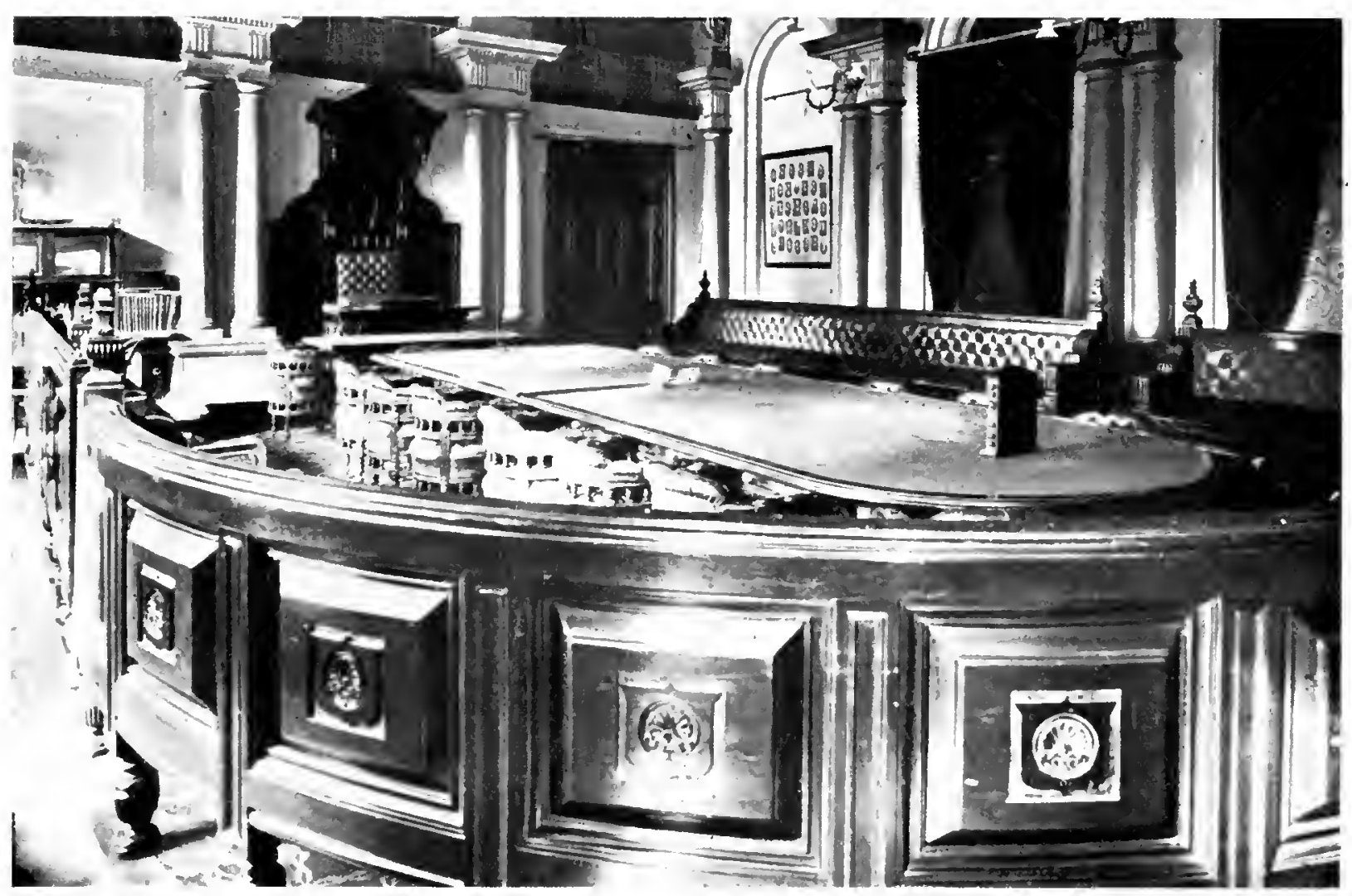

Red Cedar Fittings.

Council Chamber, Town Hall, Syclney. 


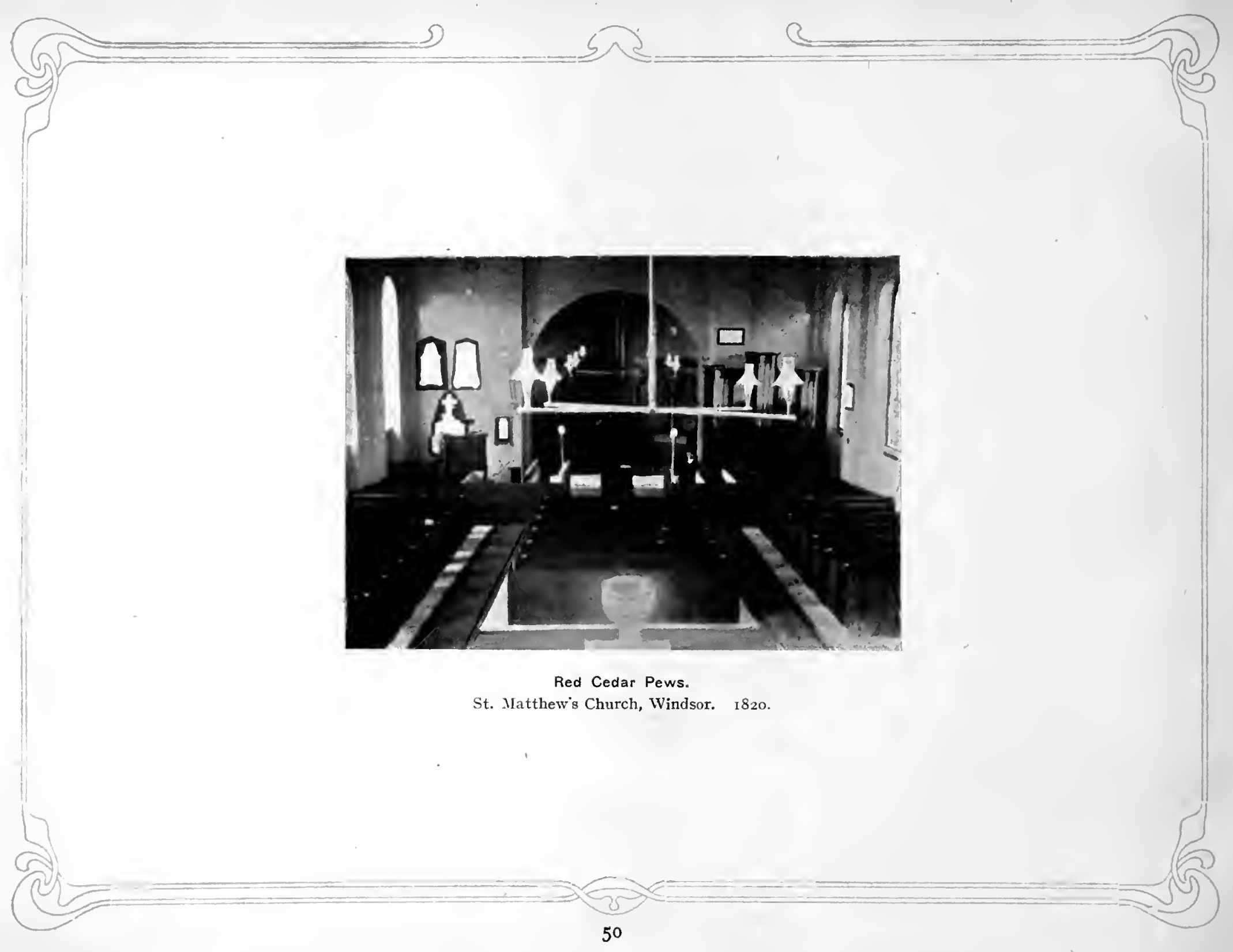




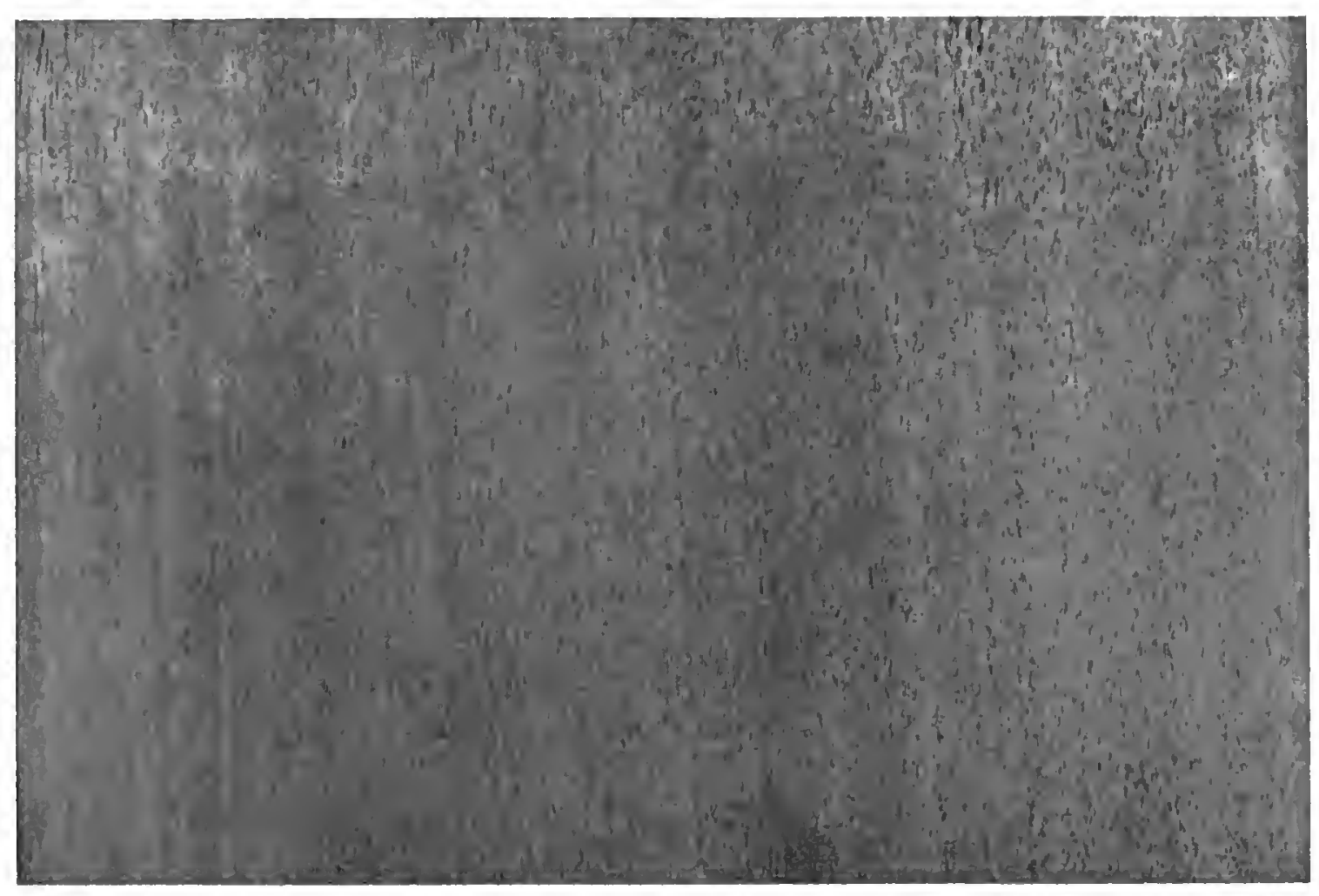

LONG JACK.

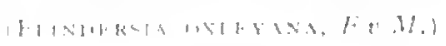




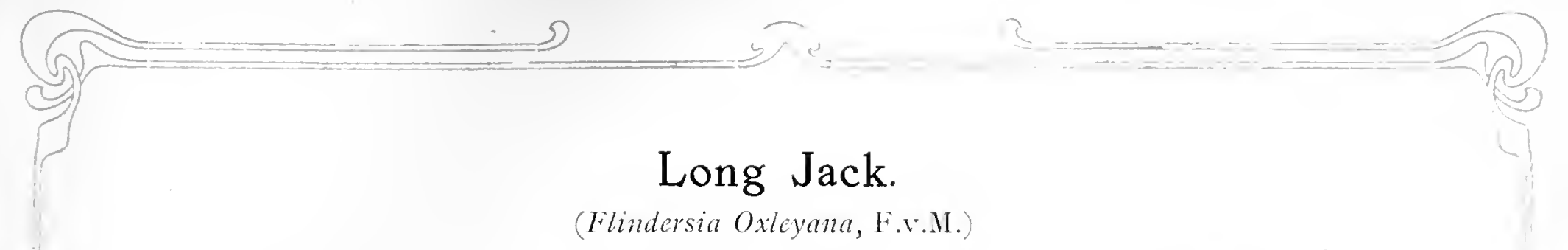

This timber is also known vernacularly as Mountain Ash and Iellow Mood, but these are only recorded here for identification of the wood and not to be perpetuated, as it is a distinct advantage for a timber to have only one commercial name, and that, if possible, a descriptive one of the wood, or at least one that shall give some index to its qualities. In this case the adjective evidently has been given by timber-getters in reference to the long straight stem, for the tree attains an average height of I2o feet, with an average diameter of 3 feet. The name Mountain Ash is retained for the Eucalypts going under that appellation, and Yellow Wood for Rhodosphaera rhodanthema, so that it is as well now to keep Long Jack for $F$. Oxleyana. It is a light yellowish coloured timber, fairly hard, strong, durable, heavy, and close grained, especially the latter in a transverse section. There is no sapwood, so that it cuts out to advantage. It is suitable for bedroom suites, coachwork, panelling, picture frames, and other joinery and cabinet work. The timber is sold in the markets under its several common names.

Description of the Tree.-A large forest tree of the Coastal brush land, attaining a height of over Ioo feet, with a thin, lightish coloured, compact, fairly smooth bark. Leaves opposite, crowded under the flowering panicles; leaflets four to ten, with or without a terminal odd one, broadly lanceolate, oblique, inclining to falcate, narrowed into a clistinct petiolule, sometimes with minute stellate hairs underneath. Flowers in a loose many flowered panicle, shorter than the leaves. Sepals very small. Petals a little larger, glabrous, obovate, oblong. Fruit an oblong hard capsule, muricate, opening septicidally into five boat-shaped valves or cocci, without any persistent axis.

Geographical Range.-The tree is fairly plentiful in the brushes of the North Coast of New South Wales and South Coast of Queensland. 


\section{Queensland Maple.}

(Flindersia Chatawaiana, Bail.)

The common name might conjure up in one's mind a replica of the familiar maple of Canada; but, if so, one would err, for there is very little resemblance between these two timbers. In this instance the colour is slightly darker than the Canadian timber, and the figure, which is different, being less " bird's eye," is obtained by the waving lines caused by the interlocking texture, and is very effective. It is fairly hard, takes a beautiful polish, and is eminently suited for all kinds of cabinet work. It is being extensively employed in the trade for furniture, piano panels, and interior decoration. There is no timber on the Sydney market at the present time used for such a variety of joinery purposes and cabinet work, as it can be stained to imitate Walnut or Mahogany, or used in its natural state.

Description of the Tree.-A large tree with a trunk diameter from 4 to 8 feet. I.eaves opposite, petioles and rhachis more or less sharply angular: leaflets usually seven, oblong falcate, obtuse, or with a more or less acuminate obtuse point, sometimes very oblique at the base, 3 to $4 \frac{1}{2}$ inches long. $I_{2}^{\frac{1}{2}}$ to $2 \frac{1}{2}$ inches broad, underside somewhat pale. Panicles rather large and spreading. Flowers not known. Fruit 3 inches or more long, oblong, but tapering at each end, pentagonal, prominently marked with dark musselsha ped scars, which gives to the fruit somewhat the apfearance of a fir cone. (F. M. Bailey, Queensland Flora, Part I, p. 240.)

Geographical Range.-Cardwell to Herberton, Queensland. 


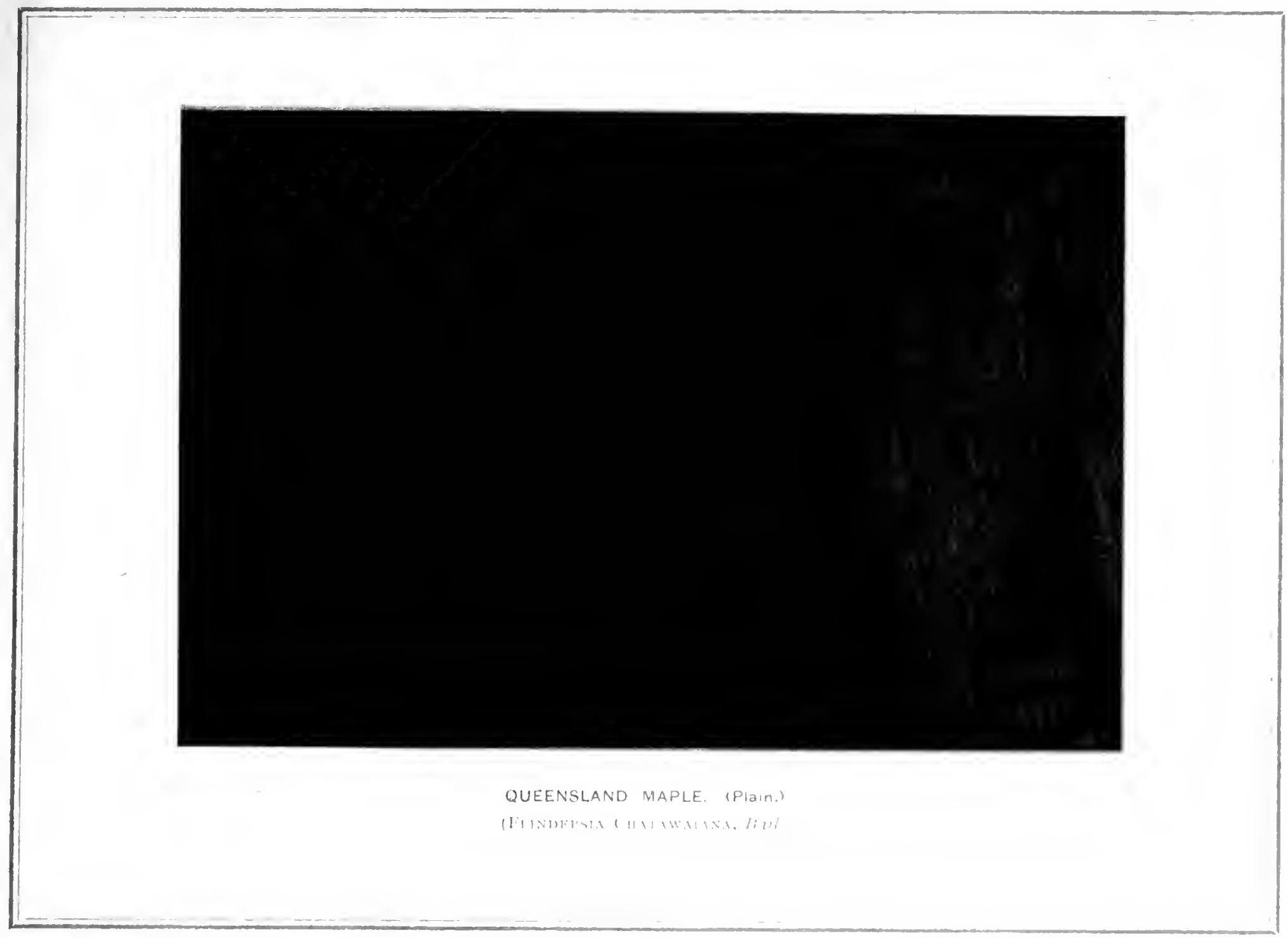




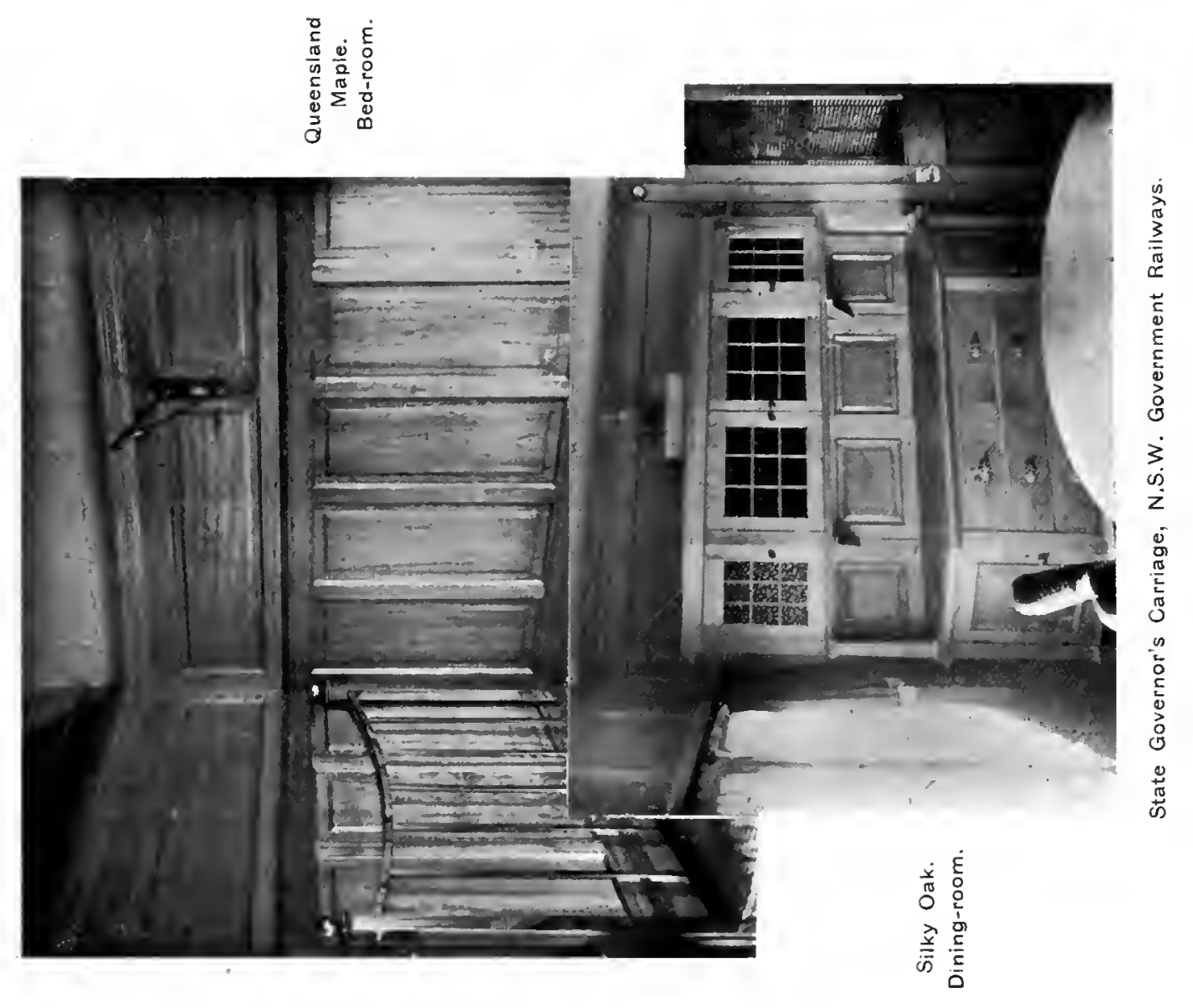




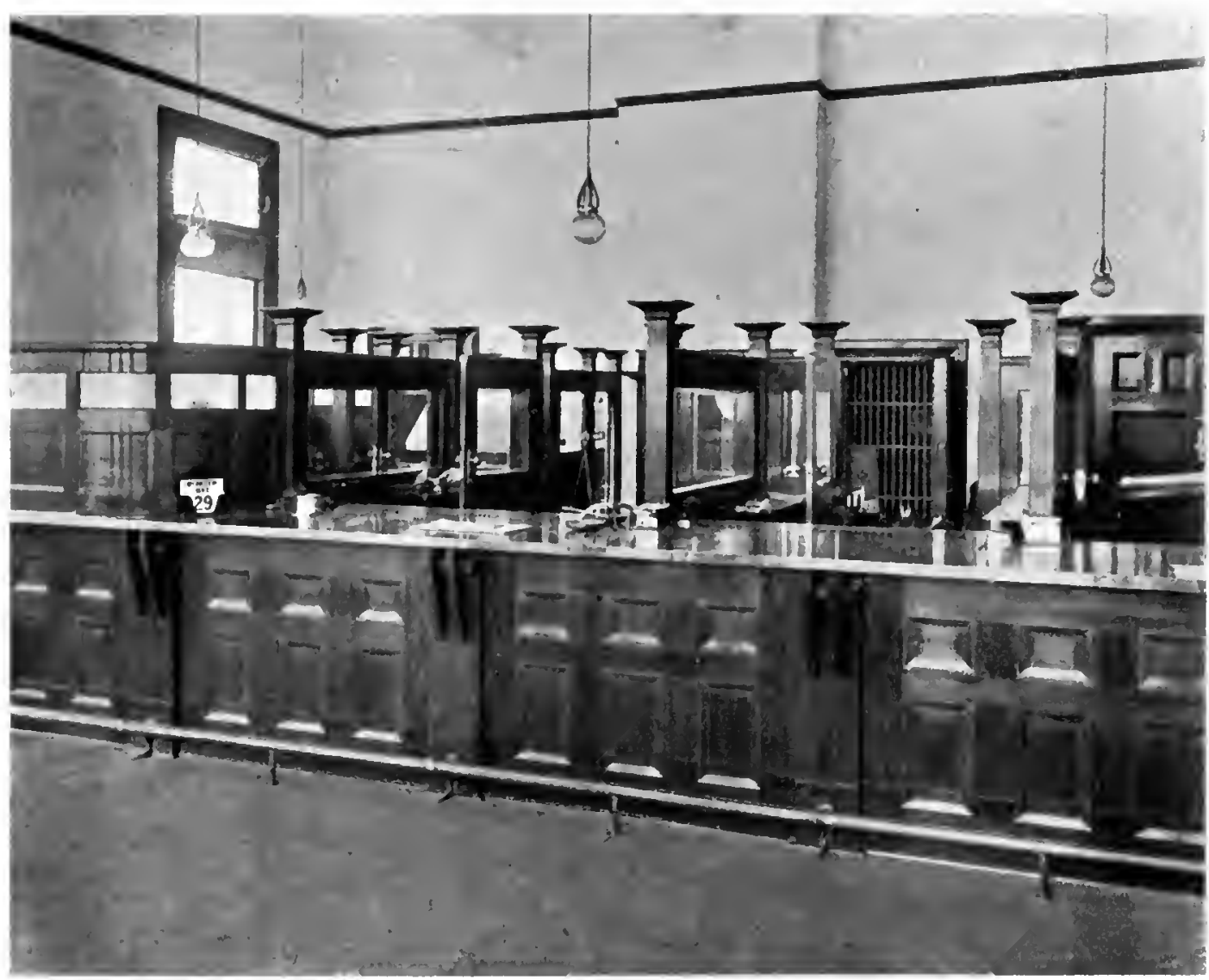

Queensland Maple.

Bank N.S.W., Melbourne. 


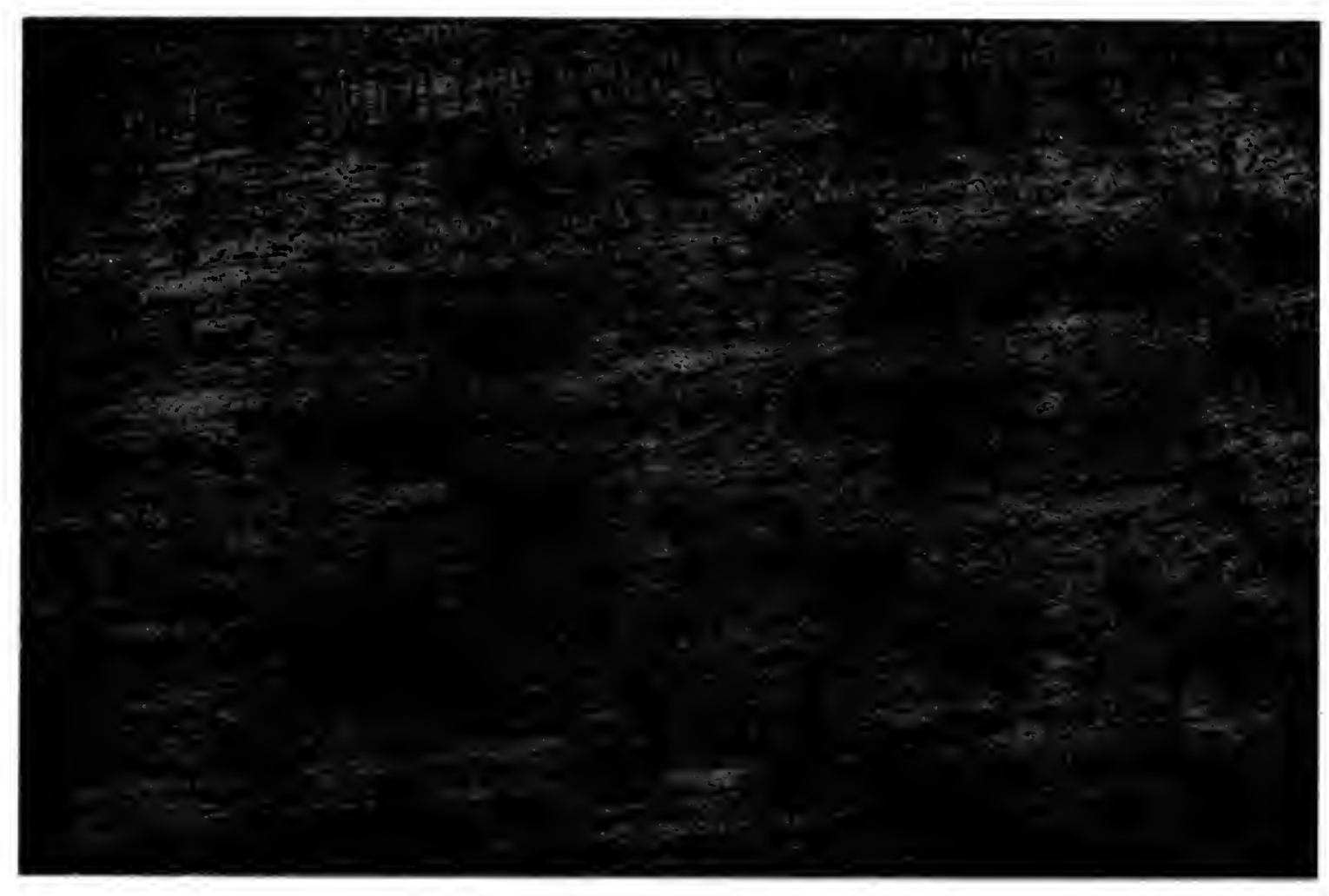

OUEENSLAND MAPLE. (Figurea.

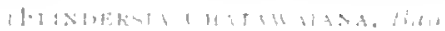



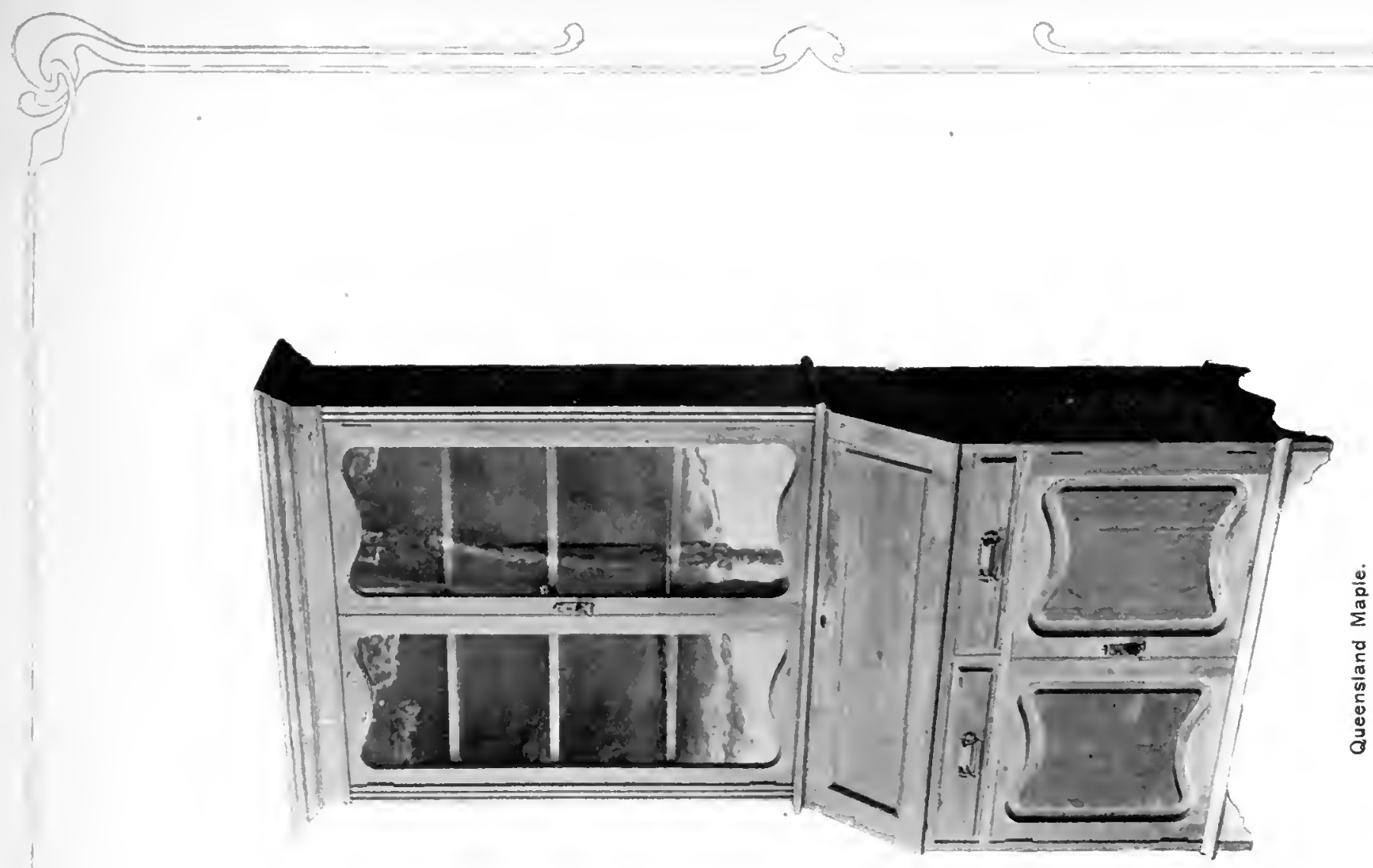
NATURAL ORDER.

\section{OLACINE $\nRightarrow$.}

$x^{2} \times$

Unfortunately, not many representatives of this Order are found in Australia, for it is from this family that the timbers of the common Ashes (Fraxinus excelsior and kindred species) of other countries are derived. The species occurring in New South Wrales is commonly known as "Maple," a not well chosen term, as it has not the lacies of any of the other timbers passing under that name. In figure it more nearly approaches the North American Sycamore, and, perhaps, some Oaks (Quercus).

Species Illustrated ix Colotr :-

Maple ('illaresia Moorei, F.v.M.). 



\title{
New South Wales Maple.
}

\author{
(Villaresia Moorei, F.v.M.)
}

Our local names are not always expressive of a distinctiveness of some well-known characters, and this is an instance. One generally associates Maple with Canada, and expects in this connection to find a timber that possesses some of the well-known features of that class of wood, but those are just what are not found in this case. It certainly is somewhat light in colour, but that is about all that obtains in the connection. The figure more nearly approaches that of English Beech, and the same may be said of the texture, hardness, and colour. It could be used for all purposes to which English Beech is applied, and would make very pretty panels or whole bedroom suites when the tout ensemble is white, or pale.coloured.

Description of the Tree.-A tall, handsome tree, found in the brush lands of the coast, with a pale, comparatively thin, yellowish corrugated bark. Leaves ovate, lanceolate or oval, acuminate, varying in size up to 3 inches broad, and 6 inches long; petiole short, coriaceous and shining, pale on underside. Flowers in lateral raceme-like panicles 2 to 4 inches long. Fruit a drupe, globular, $\frac{1}{2}$ inch diameter, the putamen hard, rugose outside.

Geographical Range.--Brush forests, Bunya Mountains, Queensland, to Bulli, New South Wales. 
NATURAL ORDER

\section{RHAMNE E.

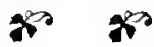

This Order is fairly well distributed over the earth, and Australia has one or two good representatives of its timbers. Red Ash is a particularly fine timber for cabinet use, the texture, weight, and colour being suitable for this special class of work. It is rarely found in the market and so is not in ordinary use.

Species Illustrated in Colour:-

Red Ash (Alphitona excelsa, Reiss). 


\section{Supple Jack.}

(Ventilago viminalis, Hook.)

This is a timber that is little known outside its geographical area. It is hard, heavy, dark coloured, and so would only be useful for special cabinet work; it much resembles in some respects the dark hearted Acacia timbers, and amongst these features may be mentioned its difficulty to dress. It is suitable for any kind of ornamental turnery, brush backs, fancy boxes, \&c.

Description of the Tree.-A small glabrous tree occurring in the interior of New South Wales and Queensland and Northern Territory. Leaves alternate, narrow lanceolate to lanceolate up to 5 inches long, entire, lateral veins very oblique and sometimes parallel with the edge, rather thin. Flowers small, clustered in the branches of axillary or terminal panicles. Fruit globular at the base, produced in to an oblong or linear coriaceous wing, one cell, one seed, about $\mathrm{x}$ inch long.

Geographical Range.-Interior of Queensland and New Sonth Wales. 


\section{Red Ash.}

(Alphitona excelsa, Reiss.)

This is a little known timber, and rarely found on the market, but it is, nevertheless, one of our finest native cabinet woods. It is close-grained, hard, fairly heavy, but with practically no figure-its special recommendation for this particular work being the bright red colour of the duramen. When first planed only a tinge of red is seen, but on exposure the colour deepens to a bright cardinal. It could be used for panelling, decorative tables, carving, and turning.

Description of the Tree.-A tall tree, found near water or ridges overlooking water, open country or brush forests, the young branches with a rusty tomentum. Bark hard, compact, often with a whitish coating. Leaves characteristic, alternate, ovate to lanceolate, large, entire, subcoriaceous, glabrous above, white or hoary underneath with a close tomentum, veins prominent. Flowers in small umbel-like cymes arranged in dichotomous cymes in the upper axils or in a terminal corymbose panicle. Fruit globular or broadly ovoid, separating into two or three hard carpels. Seeds shining, enclosed in a red-brown arillus.

Geographical Range.-Curtis Island, Queensland, to Mount Dromedary, New South Wales. 


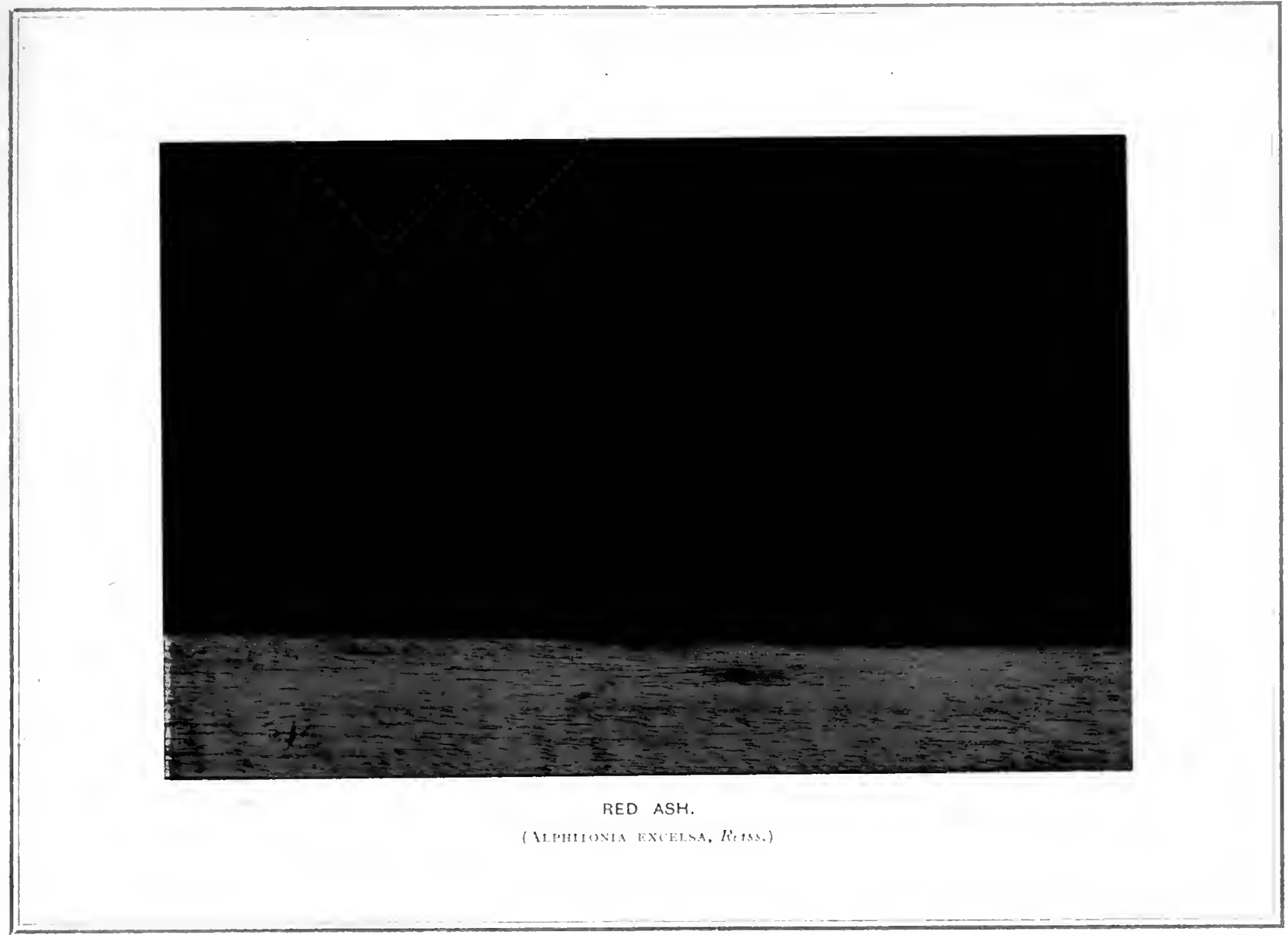


NATURAL ORDER.

\section{SAPINDACE $Æ$.}

is $x \leqslant$ is

As a timber-yielder outside Australia this Order does not seem to rank very high. In Australia the timbers are fairly numerous, hard, close-grained, tough and strong, but lacking in figure except in the case of Tulip Wood, Harpullia pendula, and perhaps Nephelium semiglaucum, which, although suitable timbers for many purposes, yet are rarely found on the market.

Species Illustrated in Colour :-

Tulip Wood (Harpullia pendula, Planch.). 


\section{Tulip Wood}

\section{(Harpullia pendula, Planch.)}

A list of the cabinet timbers would not be complete, perhaps, without a few remarks on this one, and if the tree were only more numerous the timber would be much in request. At present it only finds its way into the market in very limited supplies, so is not often now found in the cabinet-makers' workshops. That it was a regular article of commerce in the past is proved by the following quotation taken from a Toy and Fancy article advertisement in a Sydney Directory of 1848 :-

". . also Ebony, Austratian Tulip IVood, . . *Henry Parkes, Ivory and Bone Toy llanufacturer, No. 20 Hunter-street."

The wood is close-grained, hard and heavy, yet works easily, and has a pretty figure produced by a dark brown or almost black colouring, with whitish streaks. It is very suitable for turning, and has been used for small legs of ornamental drawing-room tables, and is specially suited for small mallets, and cases for medical and other scientific instruments. Apart from its cabinet qualities, the tree itself makes a very ornamental park addition, and is well worthy of cultivation. The wood looks well in ornamental boxes, picture-frames, salvers, $\& c$., ornamented with silver, when a contrast is produced between the white metal and the dark streaked colours.

$$
\text { *Afterwards Sir Henry Parkes, K.C.M.G., Premier of New South Wales. }
$$

Description of the Tree.-A tall tree of the northern brush. Leaves pinnate, leaflets usually three to six, ovate to elliptical oblong, obtusely acuminate, 3 to 5 inches long, thin or membraneous, veins prominent undemeath. Flowers in loose, slender terminal, little-branched panicles, small. Sepals under $\frac{1}{8}$ of an inch long. Petais ovate, slightly larger. Stamens five to seven, much longer than the calyx, with slender filaments in the males, small and short in the females. Fruit a glabrous capsule, $\mathrm{I}$ to $\mathrm{I}_{2} \mathrm{z}_{2}$ inch broad, the lobes inflated. Seeds without any arillus.

Geographical Range.-In the brushes of the North Coast district of New South Wales and Queensland. 


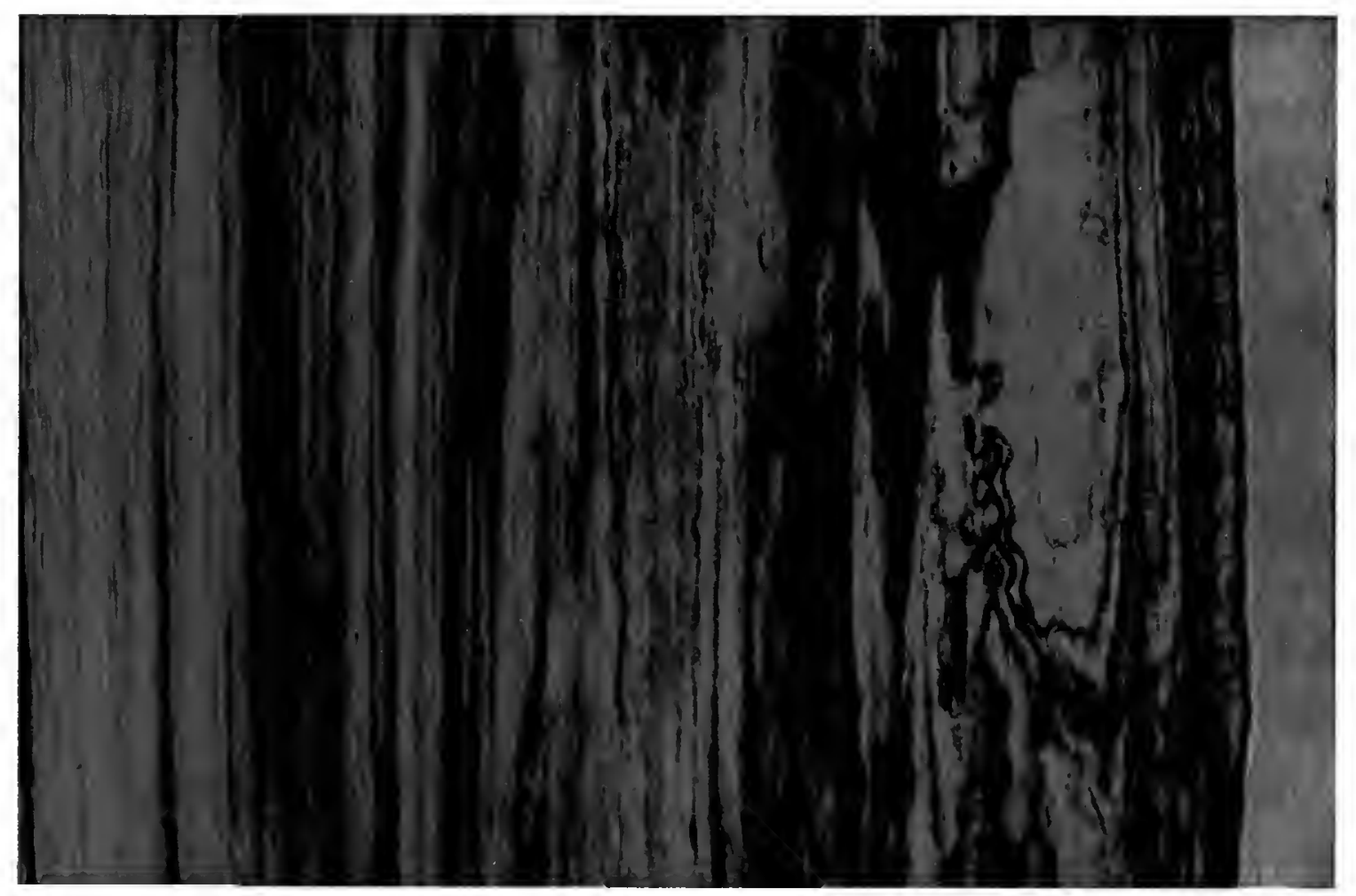

TULIP WOOD.

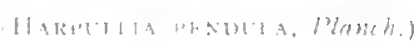


NATURAL ORDER.

\section{ANACARDIACE $F$. \\ x $x$}

ThIs is an Order with a fairly extensive distribution in the tropics and sub-tropics, and is famous for many of its economics, but the timber is, perhaps, the least known of them. The Yellow Cedar (Rhodosphara rhodanthema, Engl.) is a beautiful timber, and might be used by cabinet makers in greater quantity.

SPECIES Illustrated in Colour :-

Yellow Cedar (Rhodosphcera hodanthema, Engl.). 


\section{Yellow Cedar.}

\section{(Rhodosphara rhodanthema, Engl.)}

Rarely found on the market, but the pale yellow colour of its wood should create for it something of a demand, as it could be utilised in various ways in cabinet-work, being hárd, fairly heavy, close-grained, as well as taking a good polish, and dresses easily. It should be suitable for any cabinet-work or turnery, or any kind of ornamental cases or caskets requiring a special. colour.

Description of the Tree.-An average forest tree of the coastal (eastern) brushes, less than roo feet in height generally, having a smoothish, flaky brown bark. Leaves pinnate, with a round common petiole or stalk; leaflets from seven to nine, oblong, obtusely acuminate, entire shortly petiolate, venation distinct on the underside, where also occur domatia. Flowers large, red-coloured, in dense panicles, diœecious, very shortly pedicellate. Sepals very small, broadly ovate, very obtuse. Petals very small, recurved, ovate. Stamens ten, styles three, short, thick, diverging with capitate stigmas. Fruit a globular drupe, shining, under an inch in diameter. Seeds orbicular, flat.

Geographical Range.--A brush tree of the central Coast districts of the continent. 


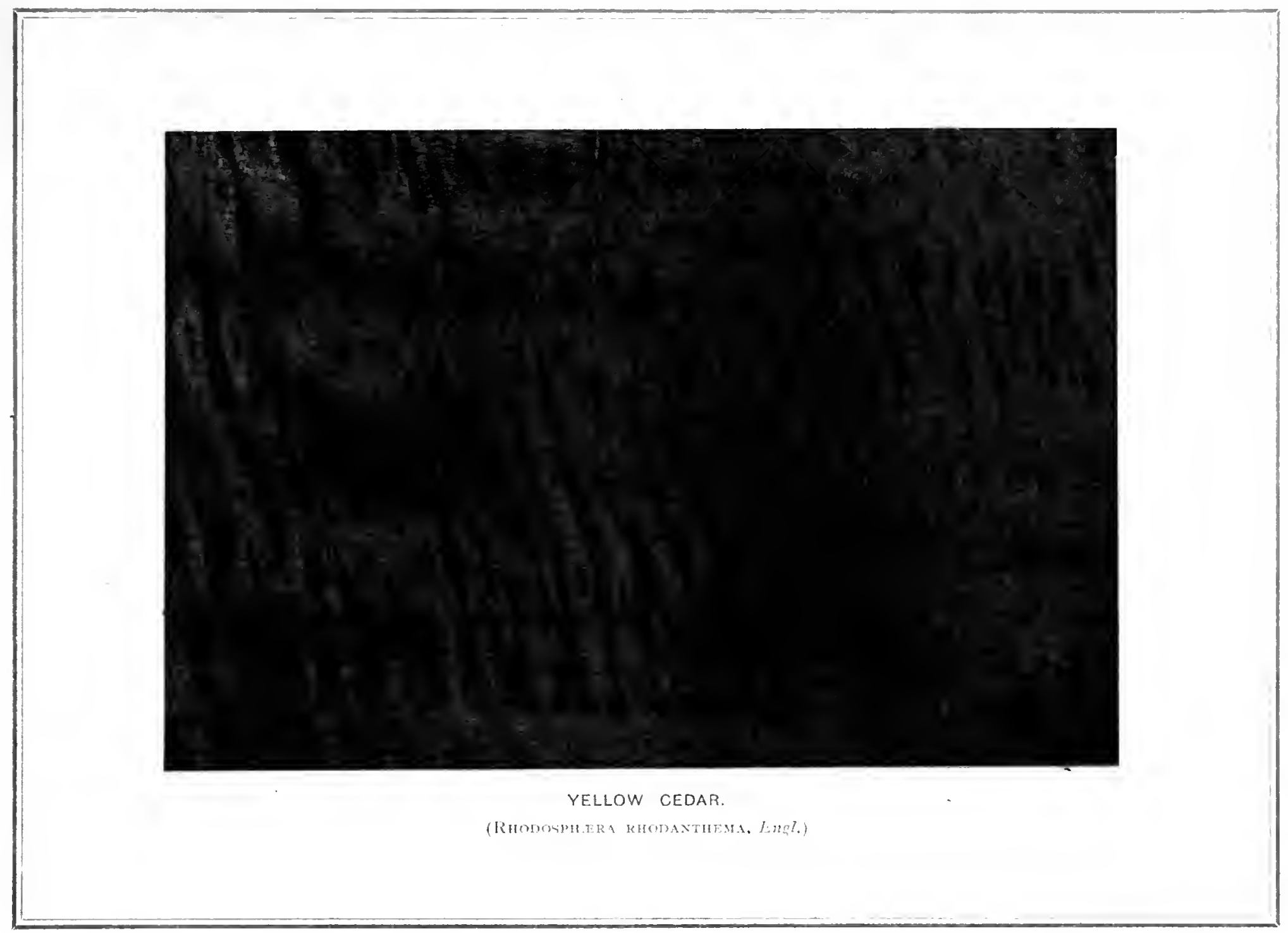


NATURAL ORDER.

\section{LEGUMINOS $Æ$. \\ *}

THIS is a very extensive Order, and has representatives in almost all parts of the world, the number of species numbering some tlousands, the Australian specimens even running into hundreds. Many of these are very ornamental and eminently fitted for cabinet-work, such timbers as Black Bean, Tortoise-shell Tulip, Myall, Eumung, Blackwood, and other Acacias form a varied selection of fine cabinet woods, and occupy no mean space in the collections in this Museum.

\section{Species Illustrated in Colour :-}

Black Bean (Castanospermum australe, A. Cunn.)

Eumung (Acacia salicina, Lindi.).

Sally (A. Maideni, F.v.M.).

Blackwood (A. melanoxylon, R.Br.).
Myall (A. pendula, A. Cunn.).

Brigalow (A. harpo phylla, A. Cunn.).

Gidgea (A. Cambagei, R. T. Baker).

Tortoise-shell Tulip (Pithecolobinm Hendersoni, F.V.M.). 


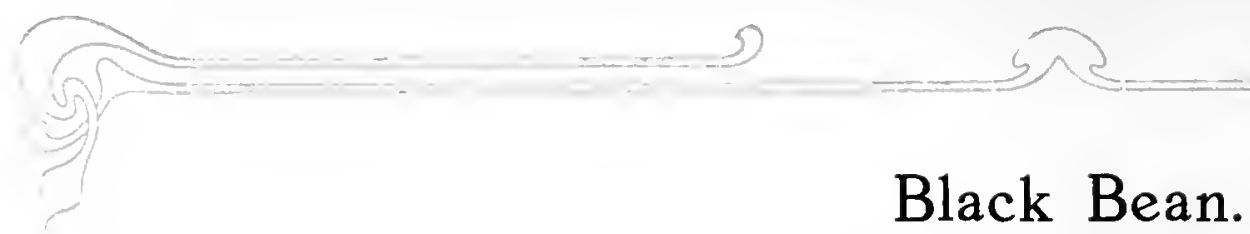

(Castanospermum australe, A. Cunn.)

Timber-getters of the two neighbouring States have given distinctive names to this wood, the northern men having bestowed the appellation of Moreton Bay Chestnut, evidently from the big seed of the pod resembling the Horse chestnut of Europe, whilst the Walesian has derived his designation of it from the pod, prefixed by an adjective suggestive of the colour of the timber. It is really remarkable how vernacular names are applied, as for instance, Red Bean, where the fruit is not a bean, but the timber has much the same character as this, although not the colour, and hence the family (sic) name. It is an "attractive wood, much resembling English and American Walnut in colour and often in figure, being dark or almost black, with a pronounced grain. In some specimens exhibited in the Museum the figure is most beautiful, excelling anything seen in exotic Walnut woods. The texture is close, and a good surface is easily produced by planing. It is fairly heavy, and is a good carving timber. It requires careful seasoning, otherwise it readily warps and twists. For doors, desks, panels, particular kinds of furniture, it is well suited, and may be regarded as a good all-round heavy cabinet timber. The tree is a fairly quick grower.

Deseription of the Tree.-One of the large trees of the coastal brush lands, distinguished by its large pinnate leaves and big pod. Bark thin, compact, pale-coloured, smooth. Leaves from I to nearly 2 feet long; leaflets eleven to fifteen, ovate, elliptical or broadly oblong, shortly acuminate, up to 6 inches long, shortly petiolulate. Flowers large, orangecoloured, in loose axillary or lateral racemes, under 6 inches long, occurring sometimes on the trunks and branches removed from the leaves. Standard about I inch in diameter. Pod 8 or 9 inches long, about 2 inches broad, three to five cells, each containing a large chestnut-like seed.

Geographical Range.-A native of the brushes of the North Coast district of New South Wales and Southern Queensland. 


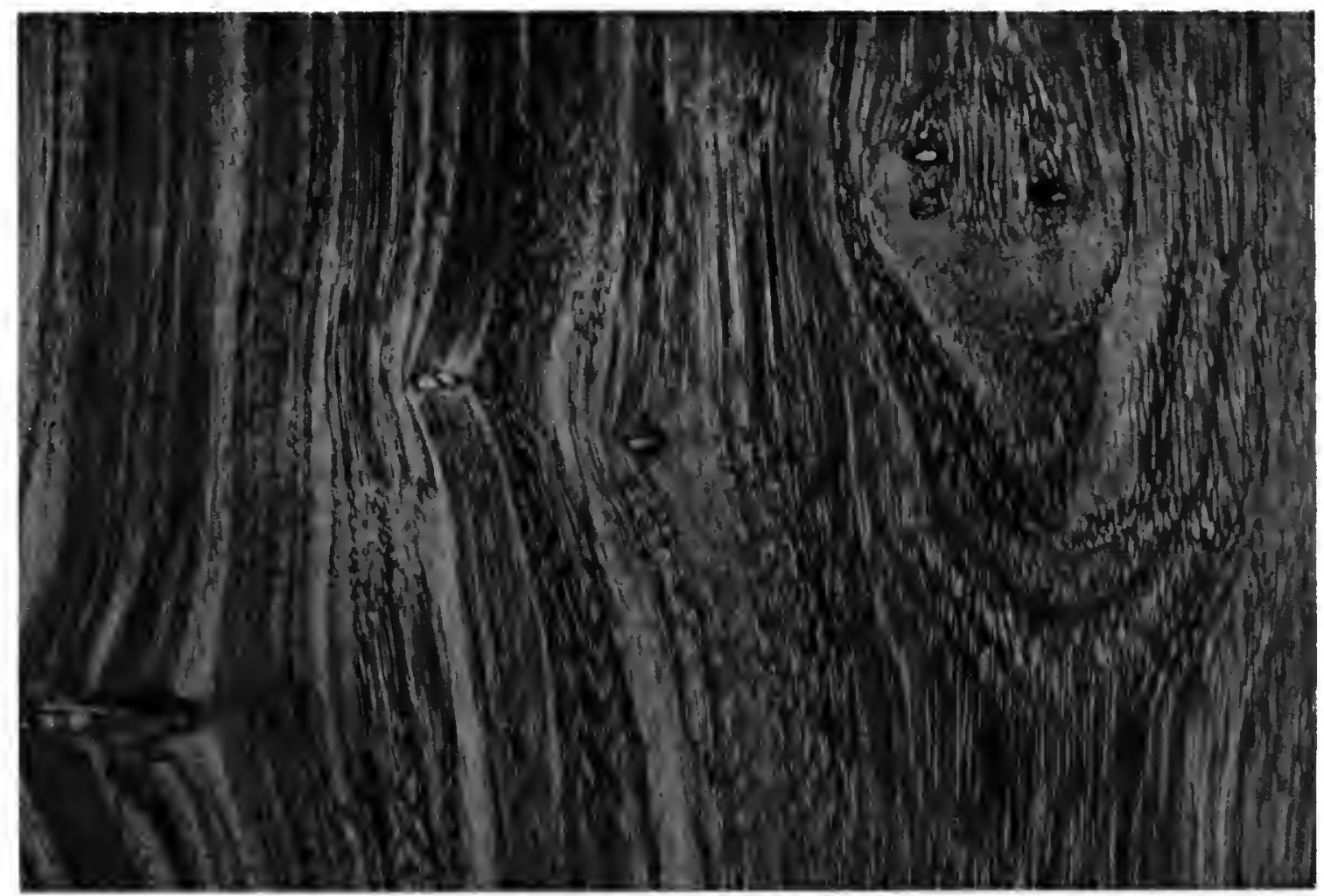

b3LArin $\quad \therefore N$ 


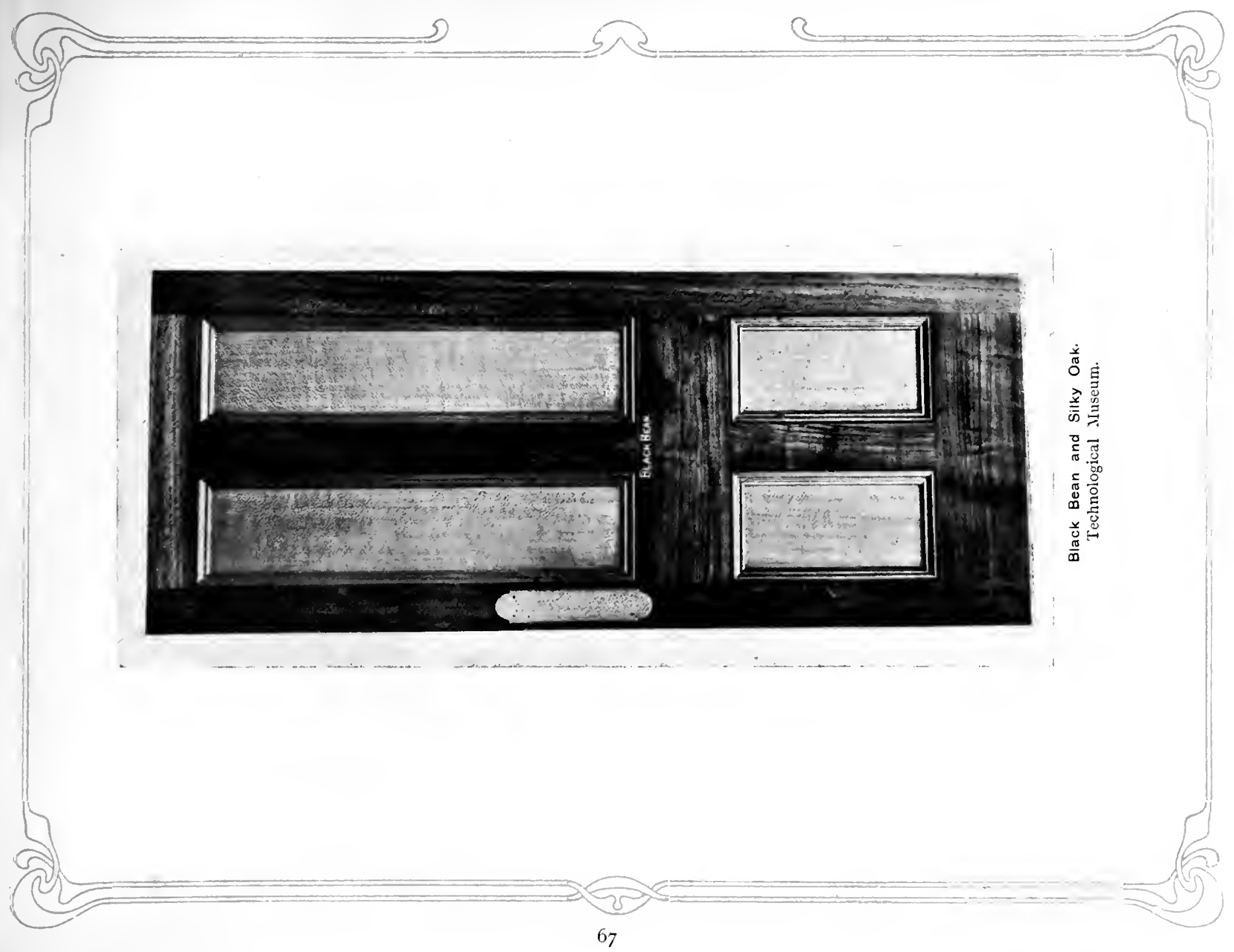




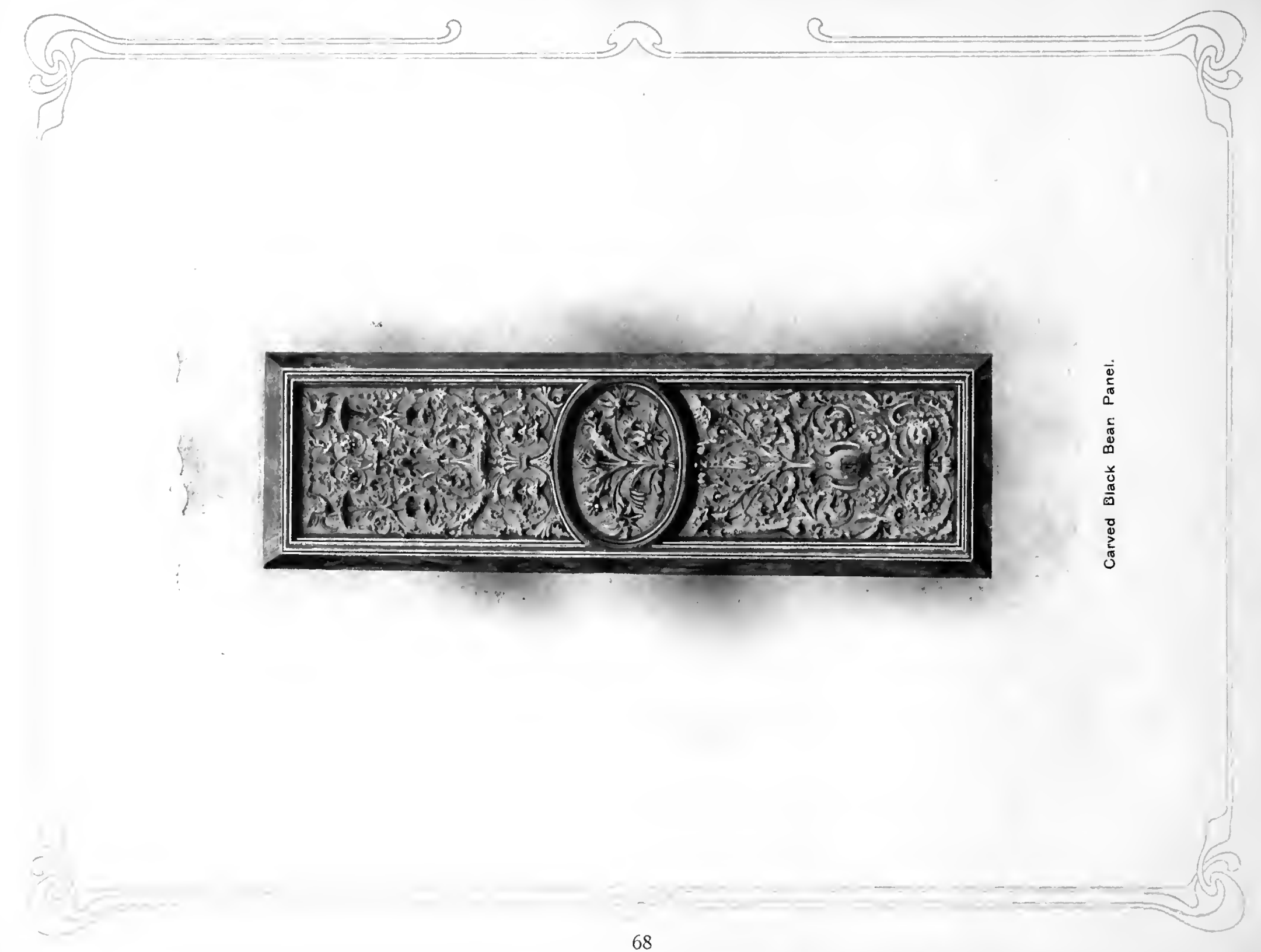




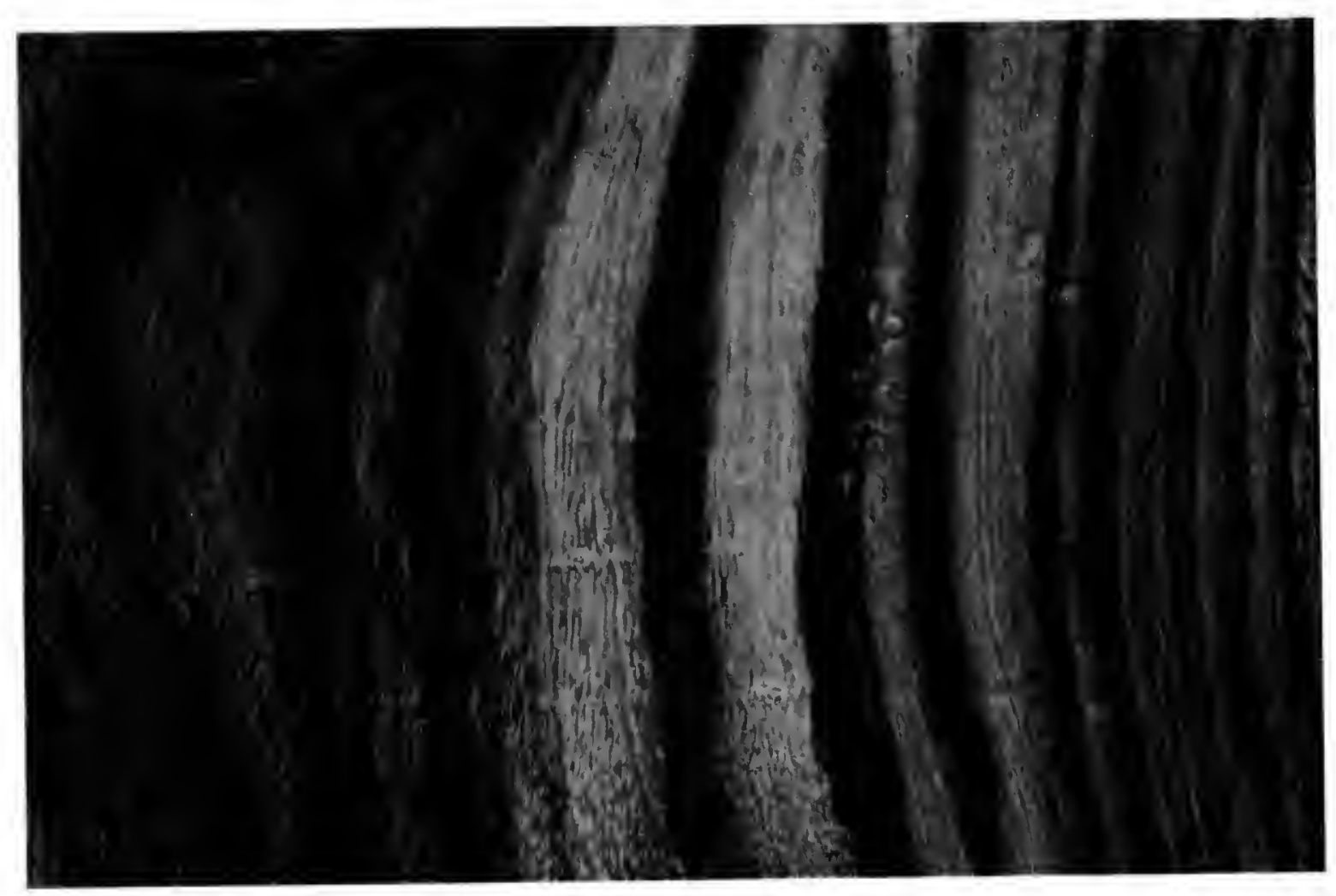

BLACK BEAN. Figured. 
西 


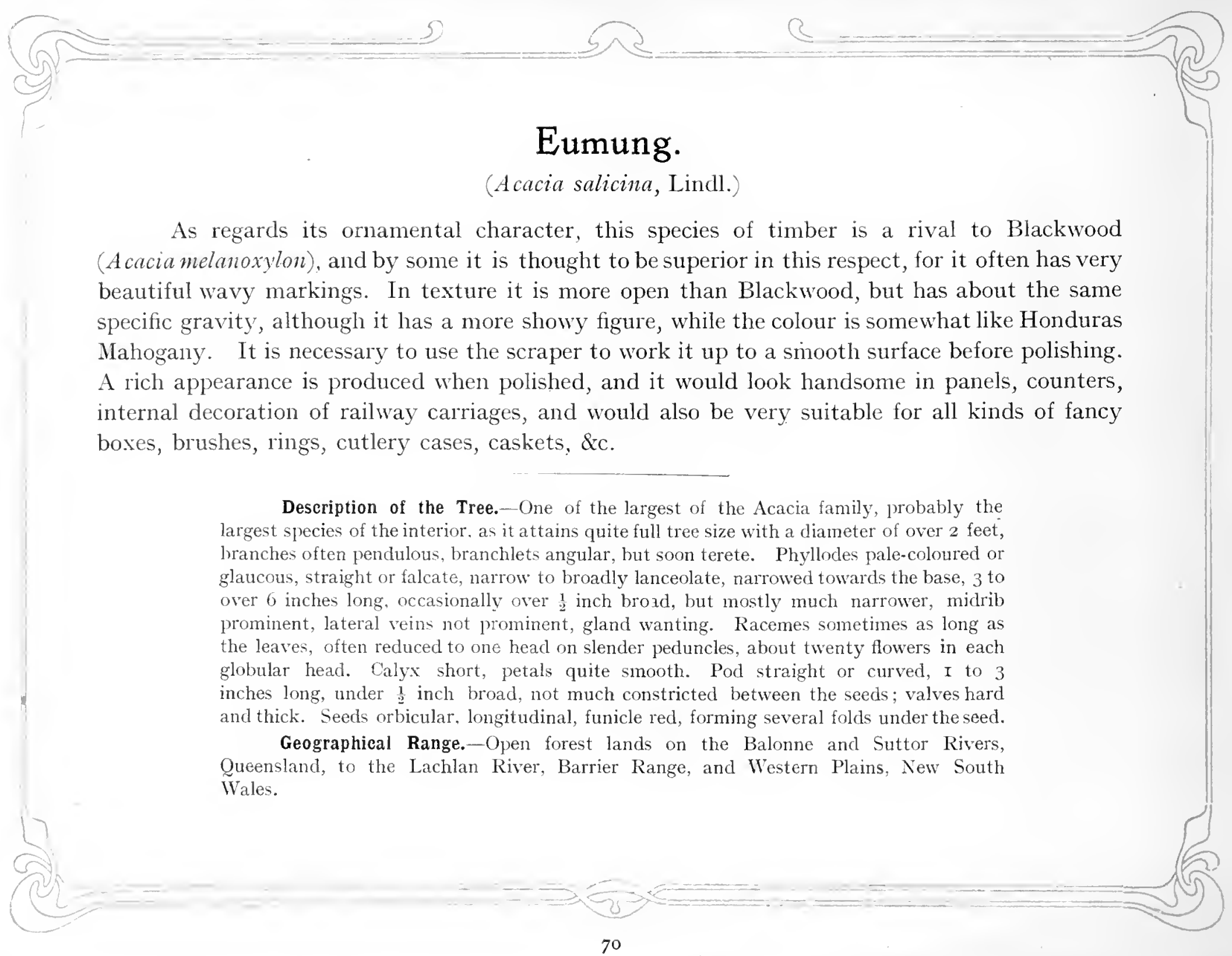




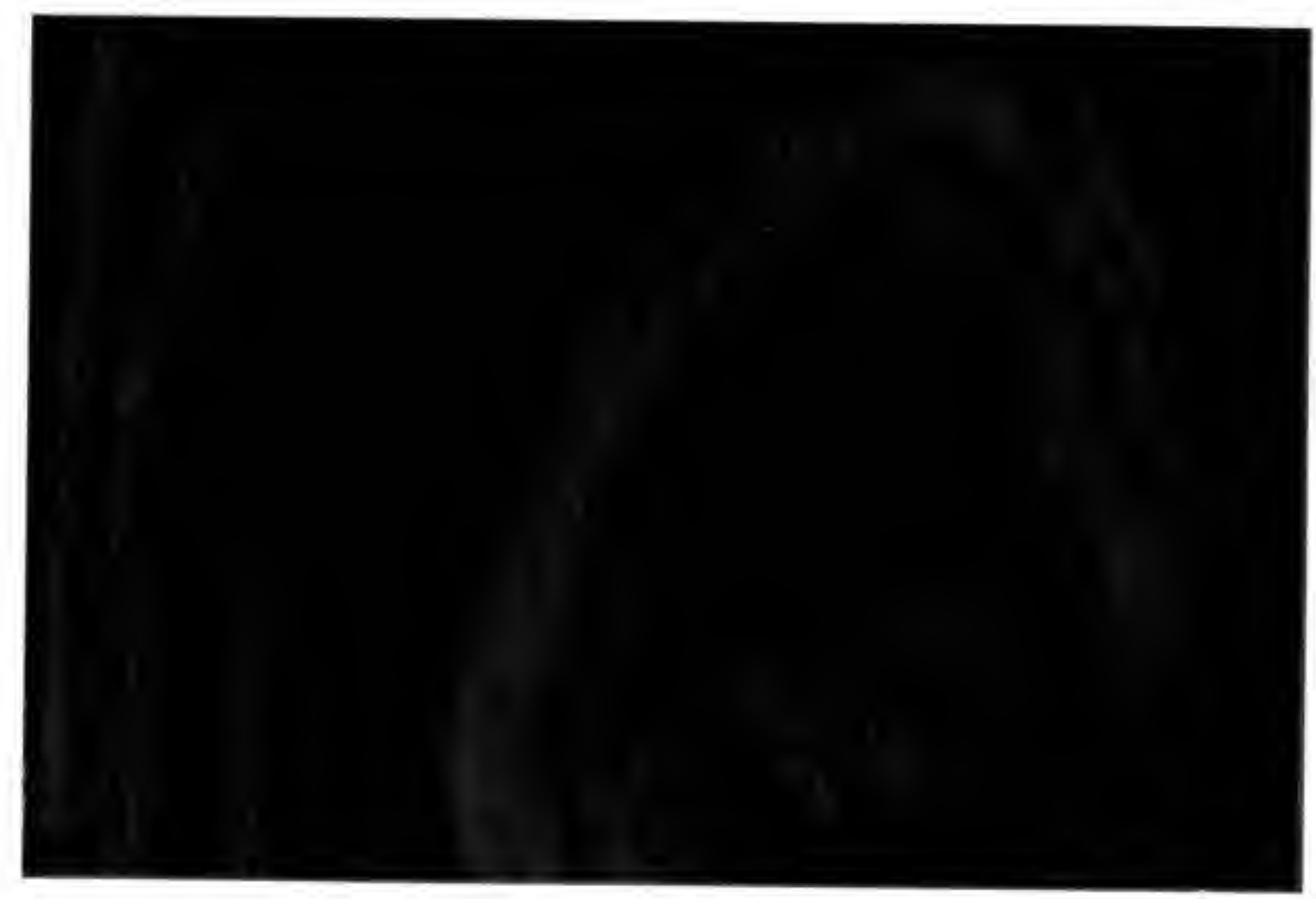

EUMUNG.

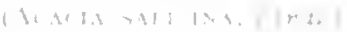




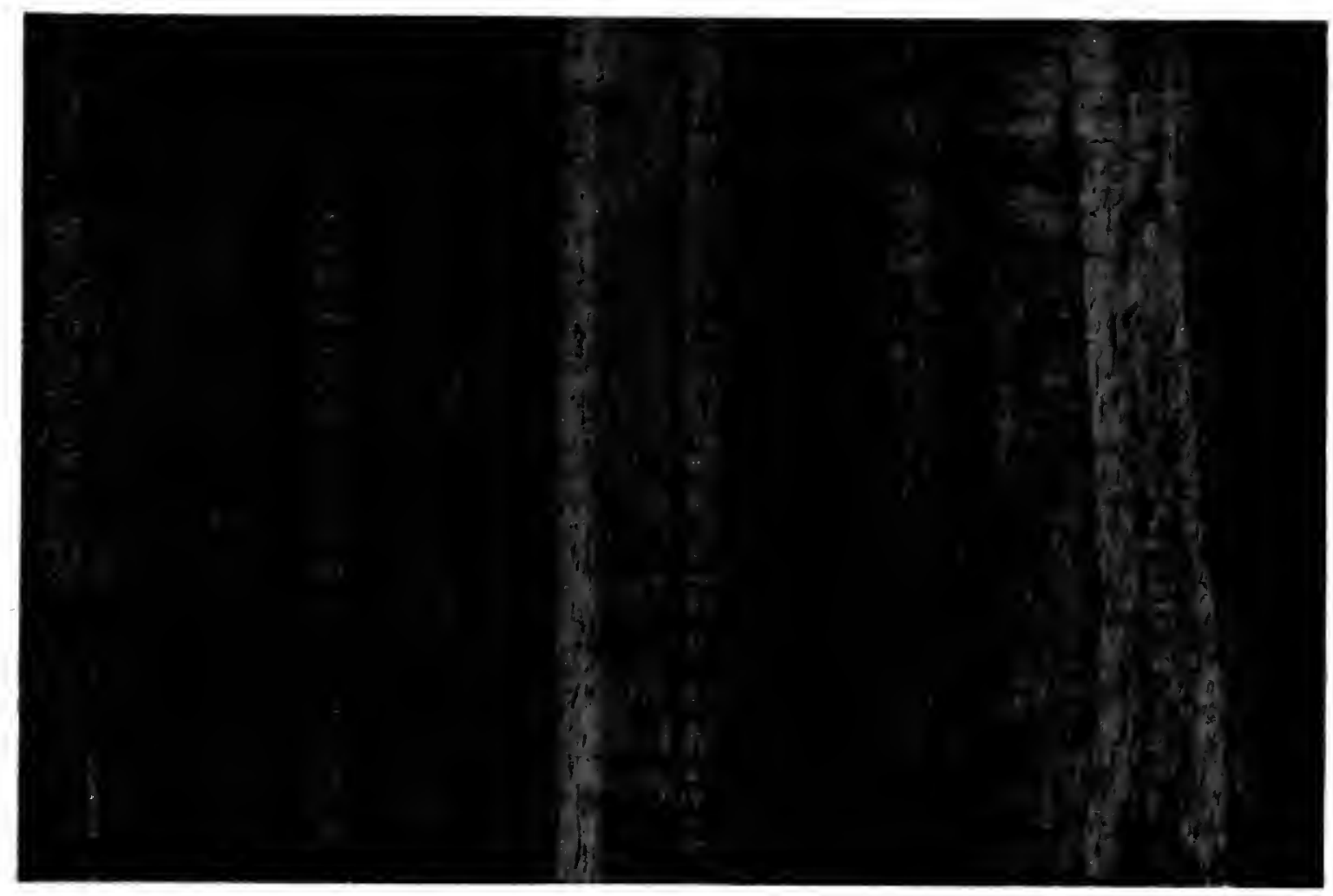

SALLY.

(Heact, MAHBS, H. U.H.) 


\section{Sally.}

(Acacia Maideni, F.v.M.)

This timber is illustrated here as it is one of the group of Acacias that differ in co'our and texture from the type or main group, such as Myall, Gidgea, Brigalow, \&c. It is palecoloured, fairly hard and light in weight, and being a rapid grower the annual rings are prominent, and when cut tangentially give a big figure. Suitable for chair-making, carriage-work, or any purpose where medium strength is required.

Description of the Tree.-A tree about 50 feet high, occurring in the brush lands of the Coast. Phyllodia large, falcate lanceolate, or oblanceolate, many veined, thin. Flowers in almost sessile spikes, the spikes solitary or two or three together, their rachis tomentose. Pod narrow, compressed, much twisted. Seeds longitudinal, shining, funicle pale-reddish, almost encircling the seed in a double fold. Wales.

Geographical Range.-Southern parts of Queensland to near Sydney, New South 


\section{Blackwood.}

(Acacia melanoxylon, R.Br.)

As a cabinet timber for all-round usefulness this one might, perhaps, be placed next to Red Cedar (Cedrela Toona), and its utilisation in this connection dates probably almost as far back in the State's history. It can be made into beautiful furniture, as it takes a good polish, which gives it a satiny sheen, thus enhancing its often ornamental figure. It is fairly close-grained, strong, comparatively light in weight, and dresses with a beautiful finish and is frequently found with a ringed figure. Apart from its utilisation for furniture and cabinet-work, it has also been tried for gun-stocks and given satisfaction. It is extensively used in the construction of railway passenger cars, office, bank, and shop fittings, also interior joinery work of passenger boats, in fact almost every purpose to which good cabinet timber can be utilised. The Central Railway Booking Office fittings, Sydney, are made from it.

Description of the Tree.-This probably is the giant of Acacias, as it attains a height of 80 or Ioo feet with a good diameter. Bark hard, rough, furrowed, and of a compact texture. Phyllodia straight, lanceolate or falcate, up to 6 inches in length and $\frac{1}{2}$ to I inch broad, much narrowed towards the base, with several longitudinal nerves and numerous anastomosing veins. Inflorescence either on a solitary peduncle or a short raceme. Flowers in head of forty or fifty. Pods flat, much curved, about $\frac{1}{4}$ inch broad with thickened margins. Seeds orbicular, funicle red, encircling the seed in a double fold.

Geographieal Range.-One of the widest distributed of our cabinet timbers, as it is found in Tasmania, Victoria, New South Wales, and Queensland. 


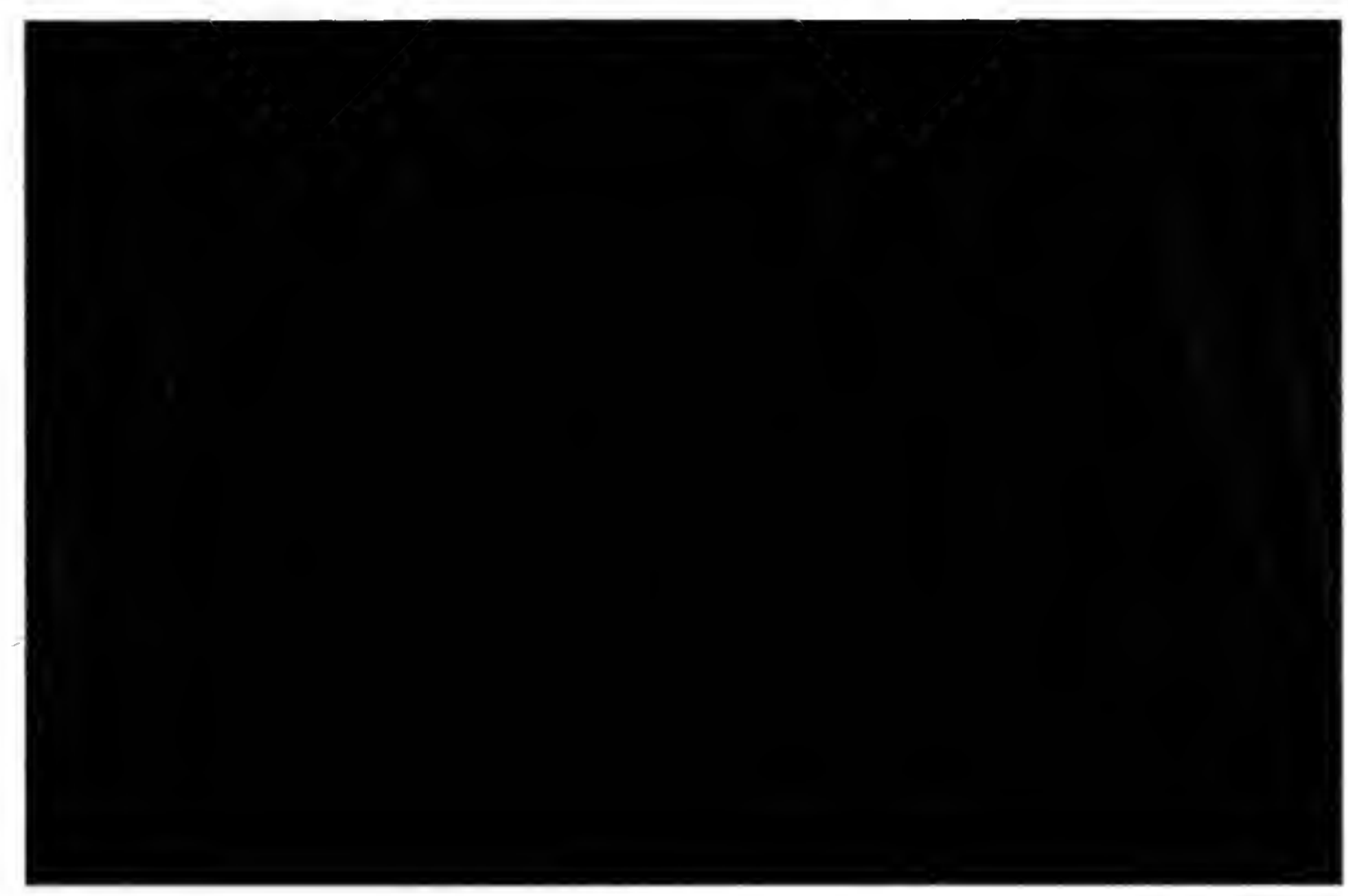

BLACKWOOD

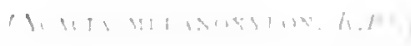




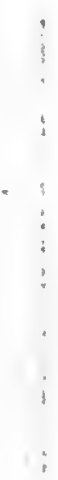



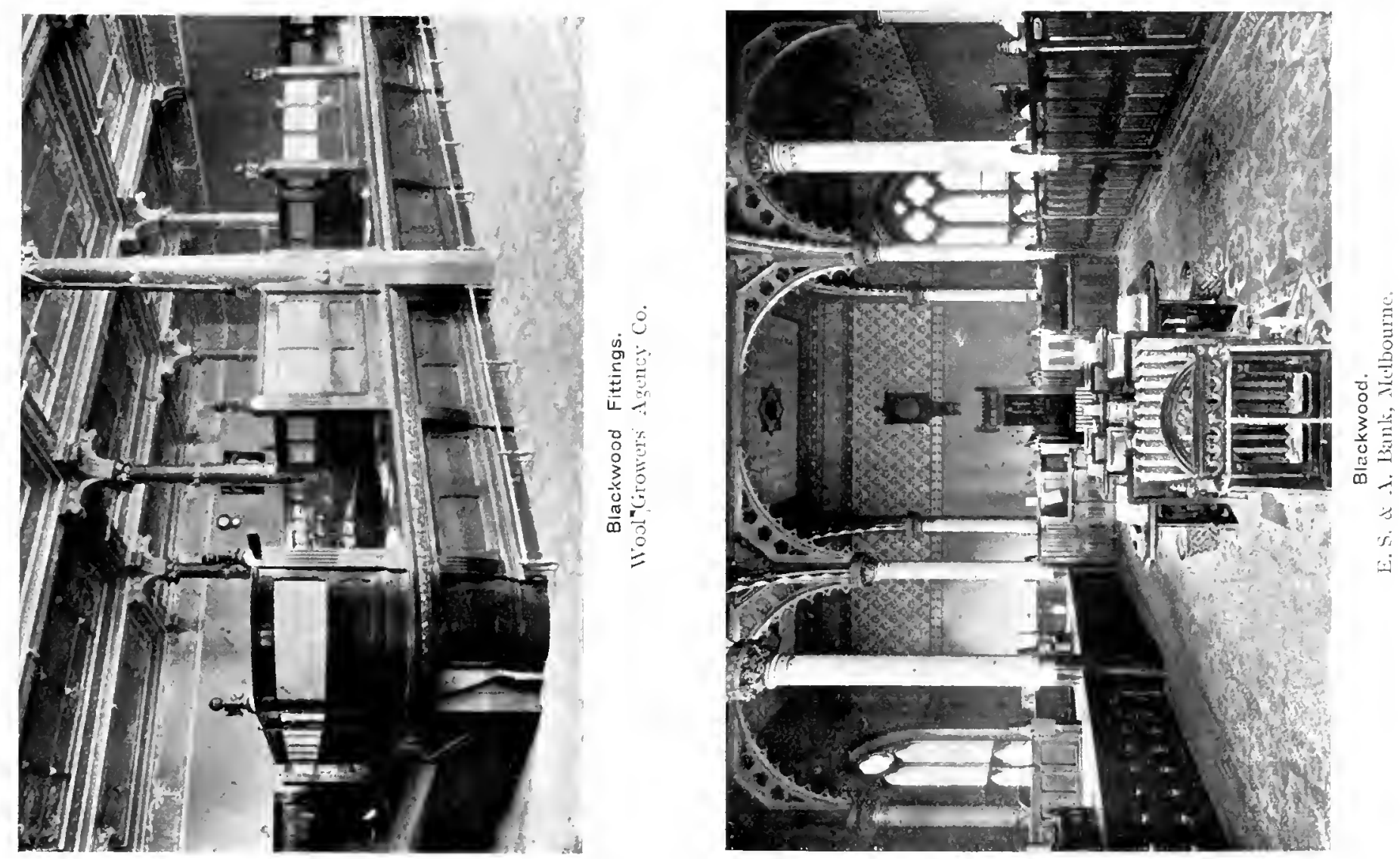


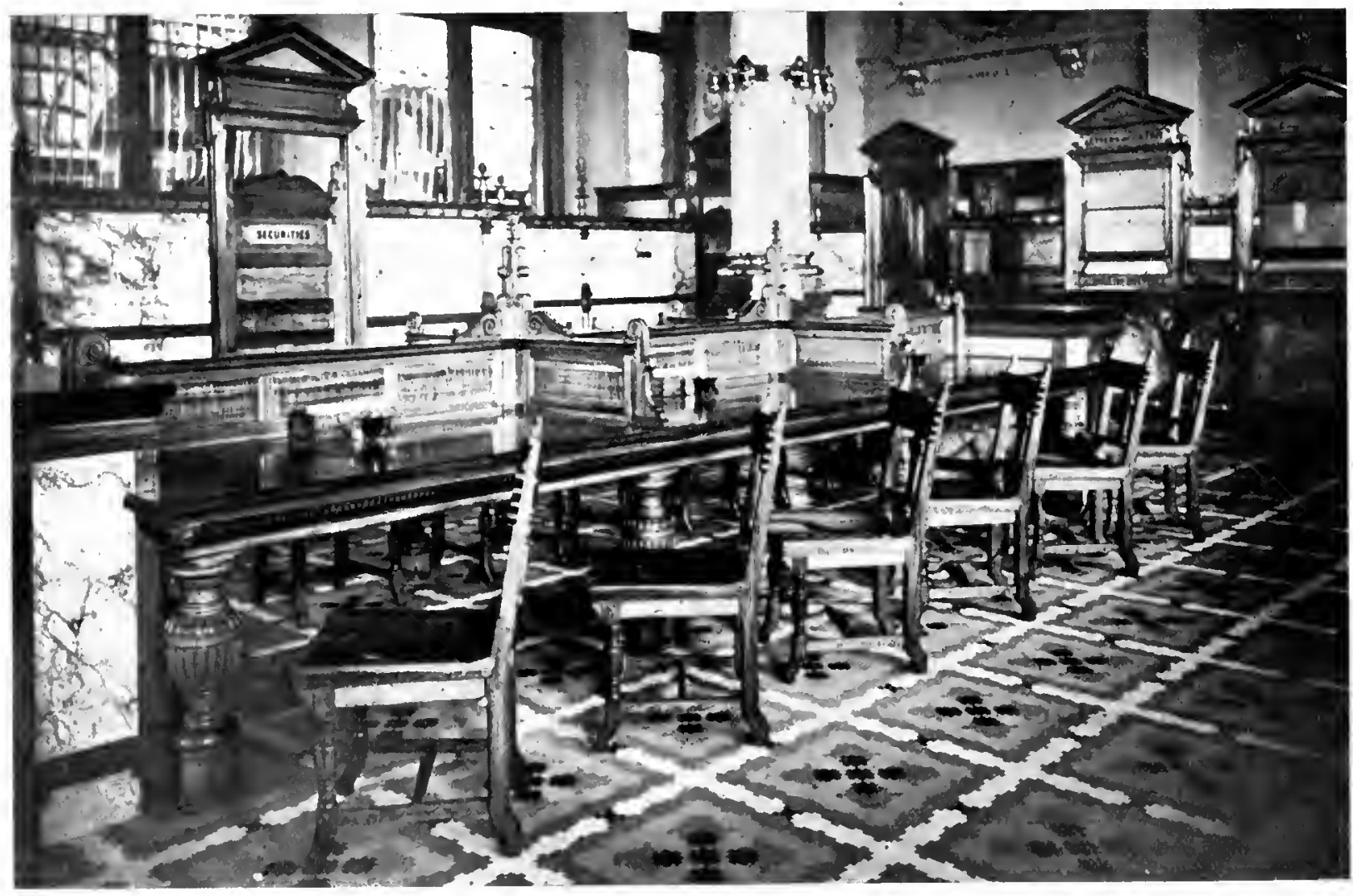

Blackwood Tables and Chairs.

Bank of Australasia, Sydney. 


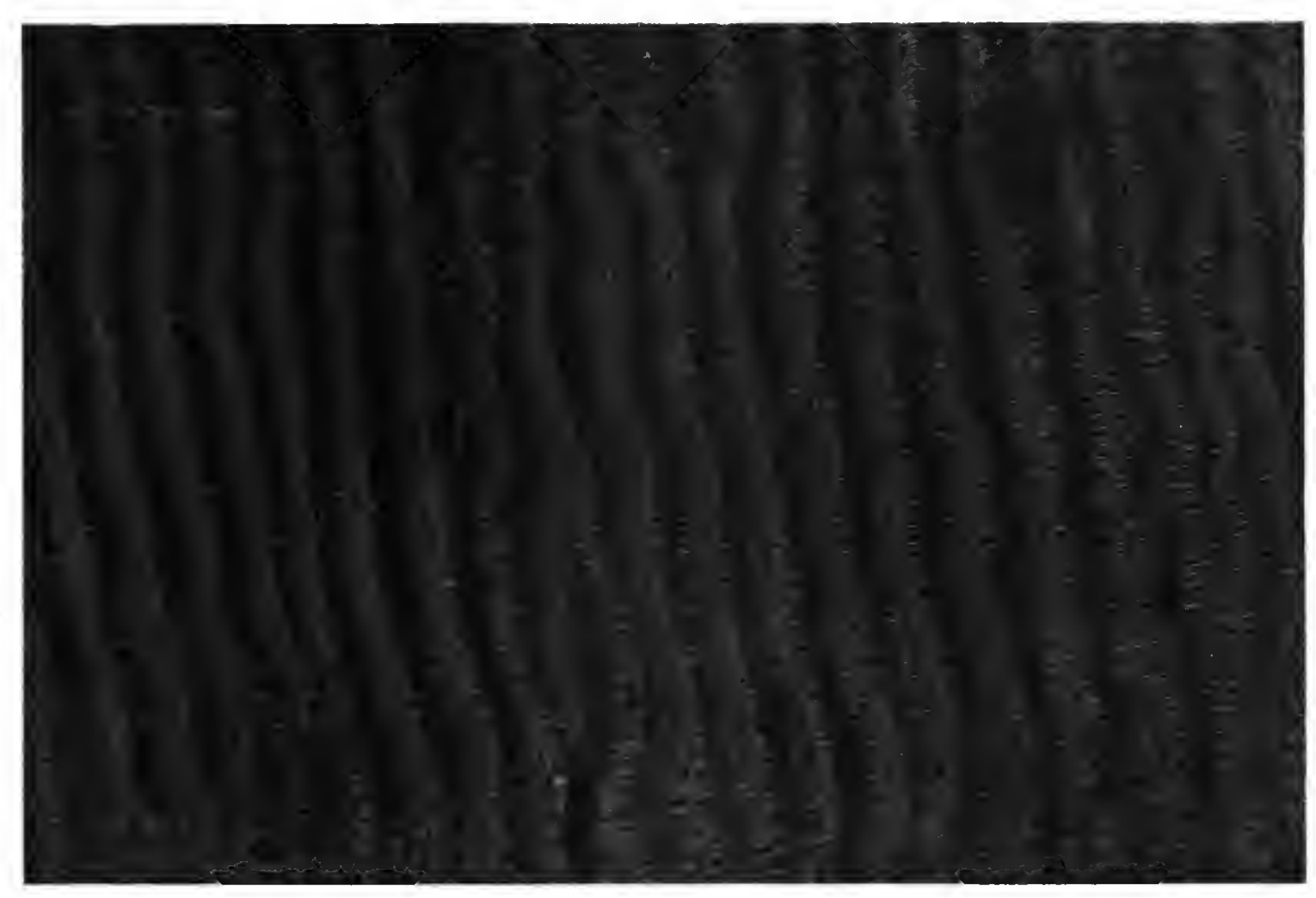

BLACKWOOD. (Ringed.)

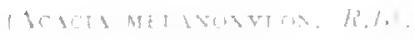




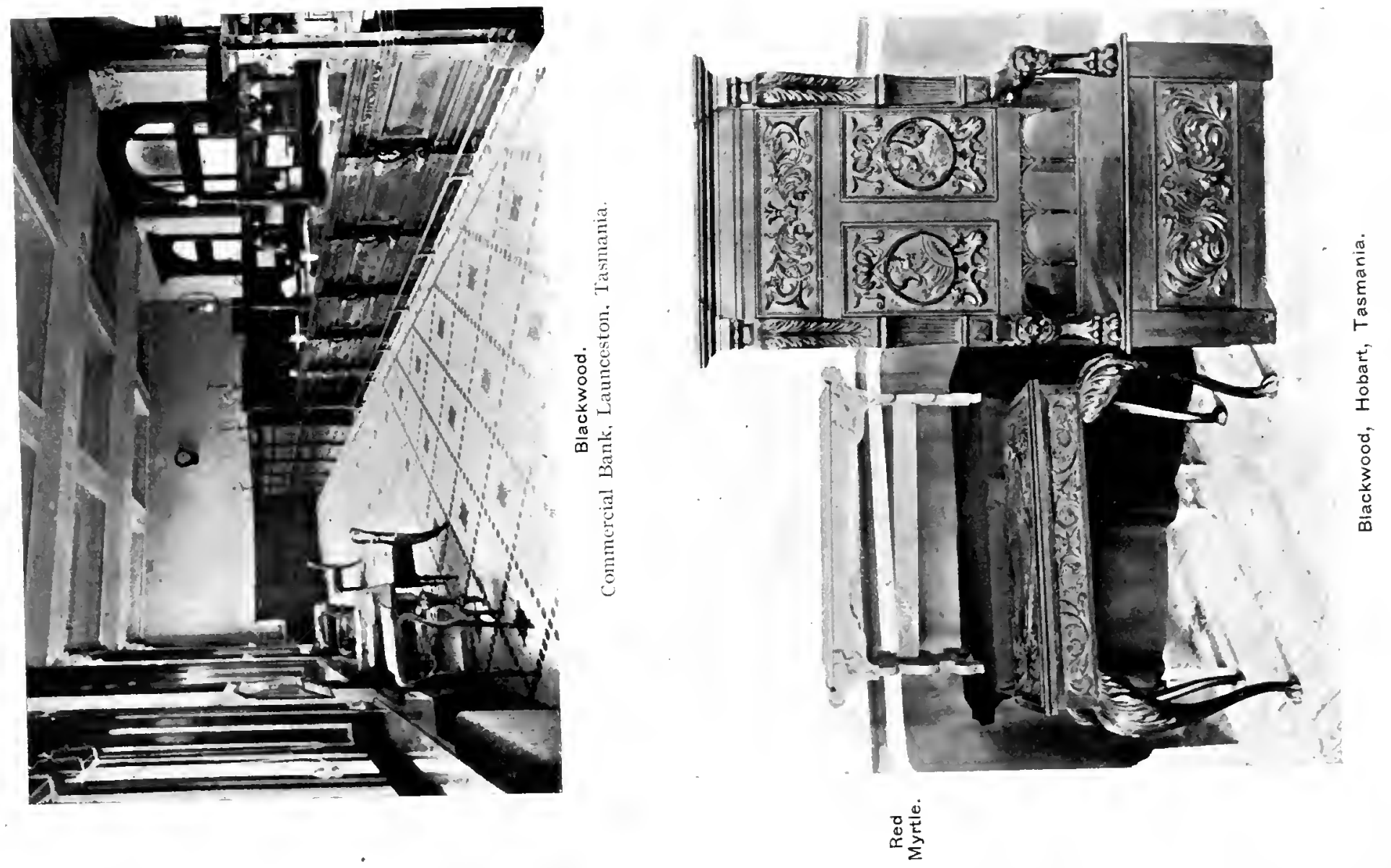


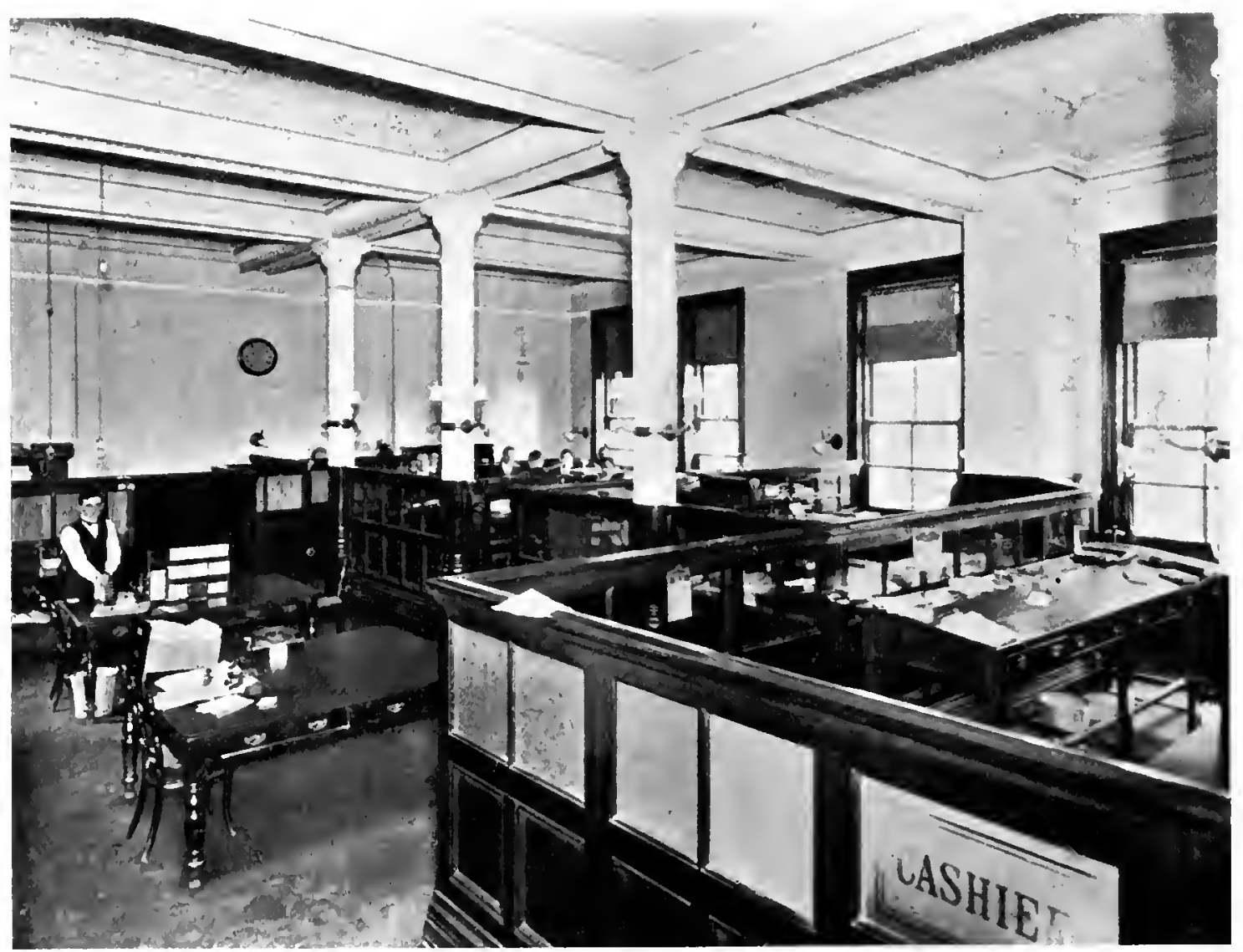

Blackwood Fittings 


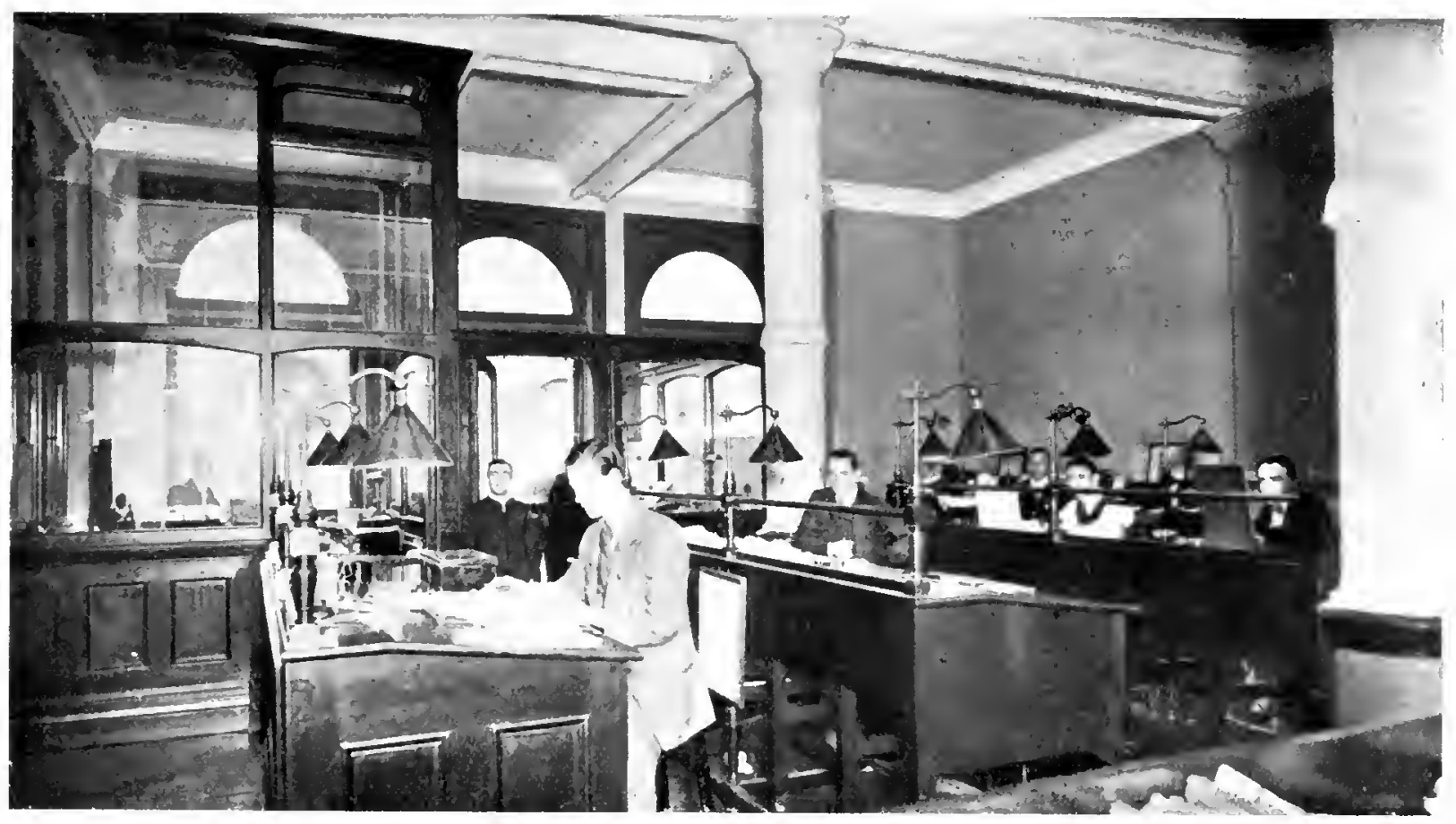

Blackwood Fittings.

C.S.R. Co., Sydney. 


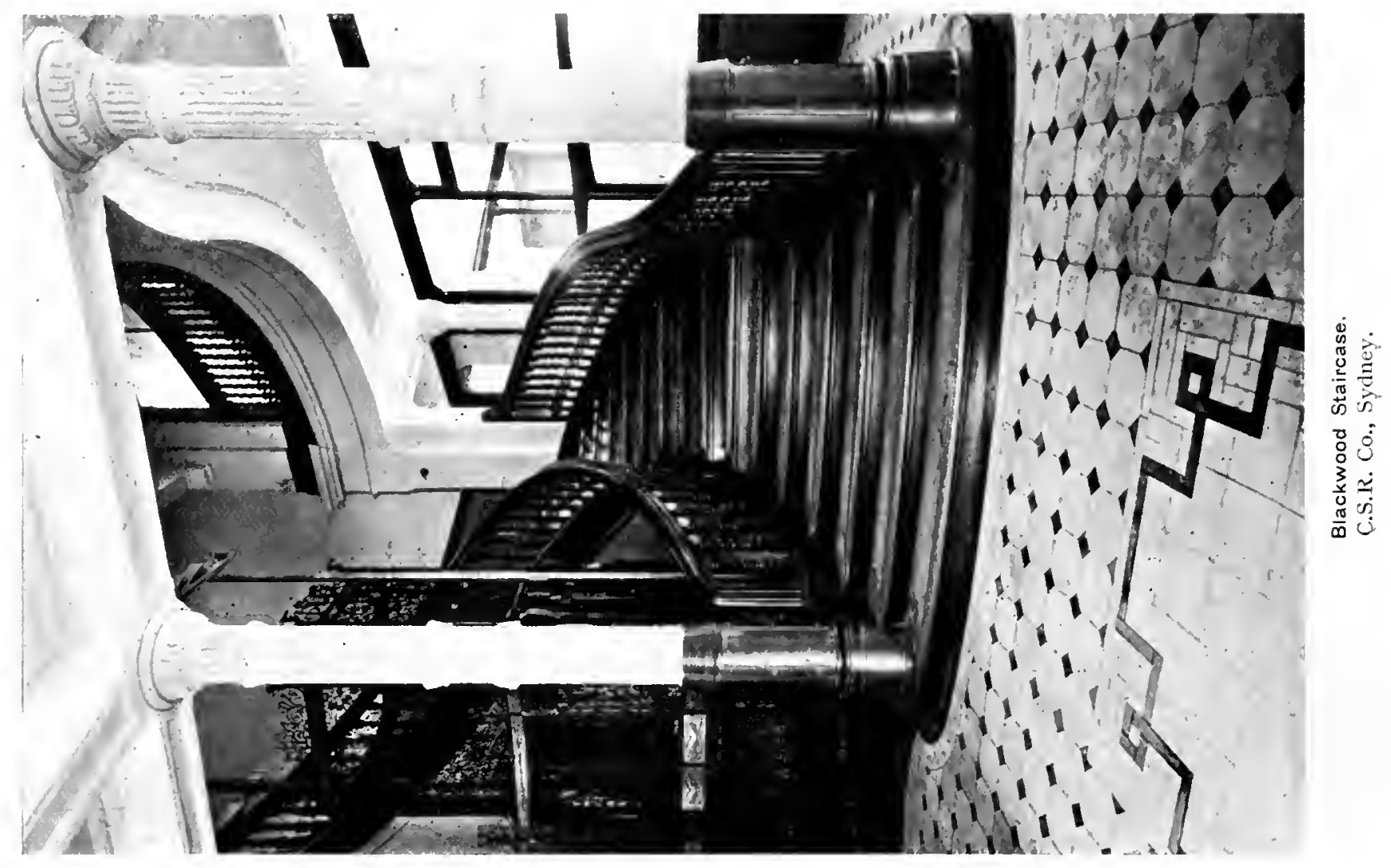




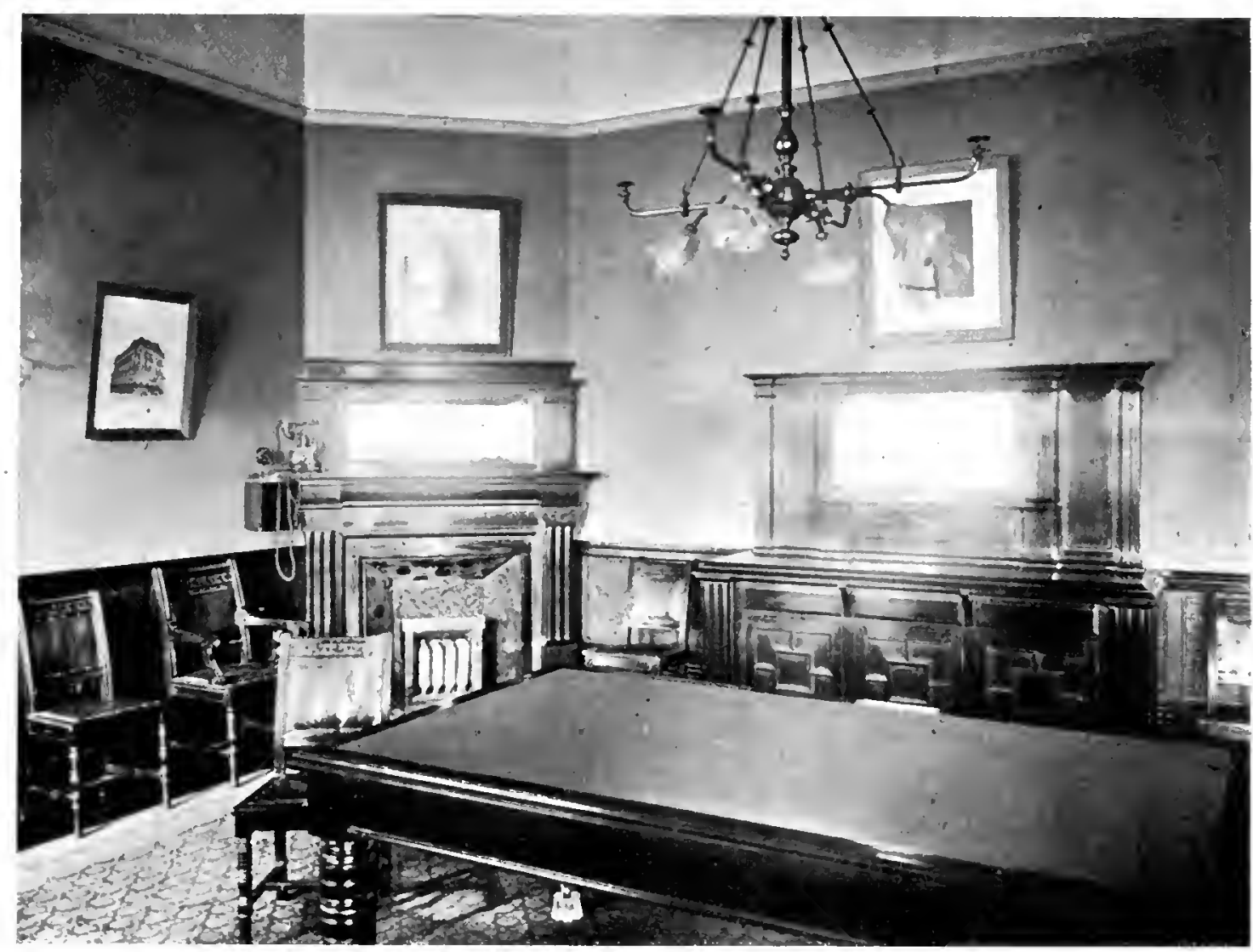

Blackwood Fittings.

Board Room, Dalgety's, Syelney. 


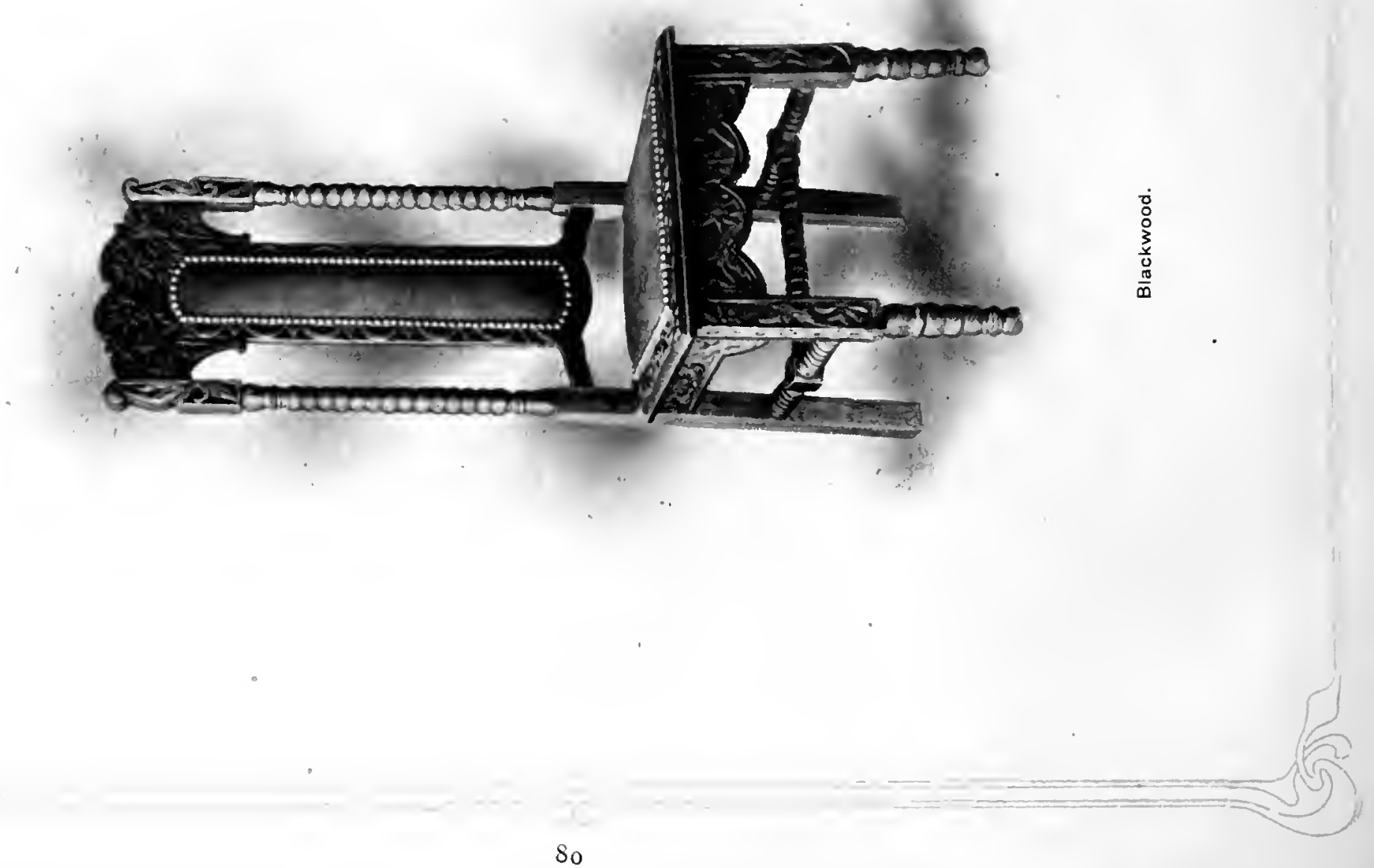




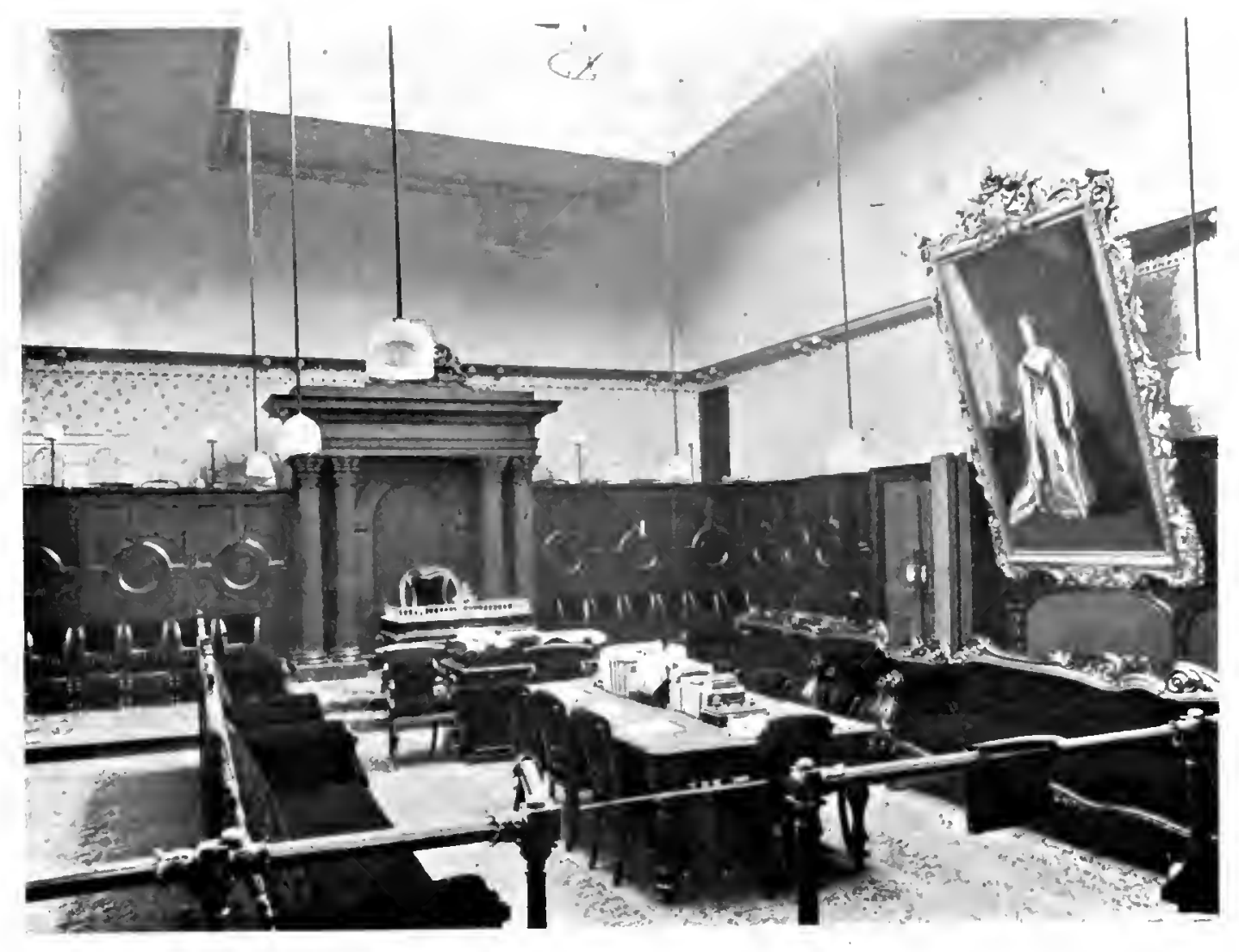

Blackwood and Cedar.

Legislative Council Chambers, Hobart, Tasmania. 


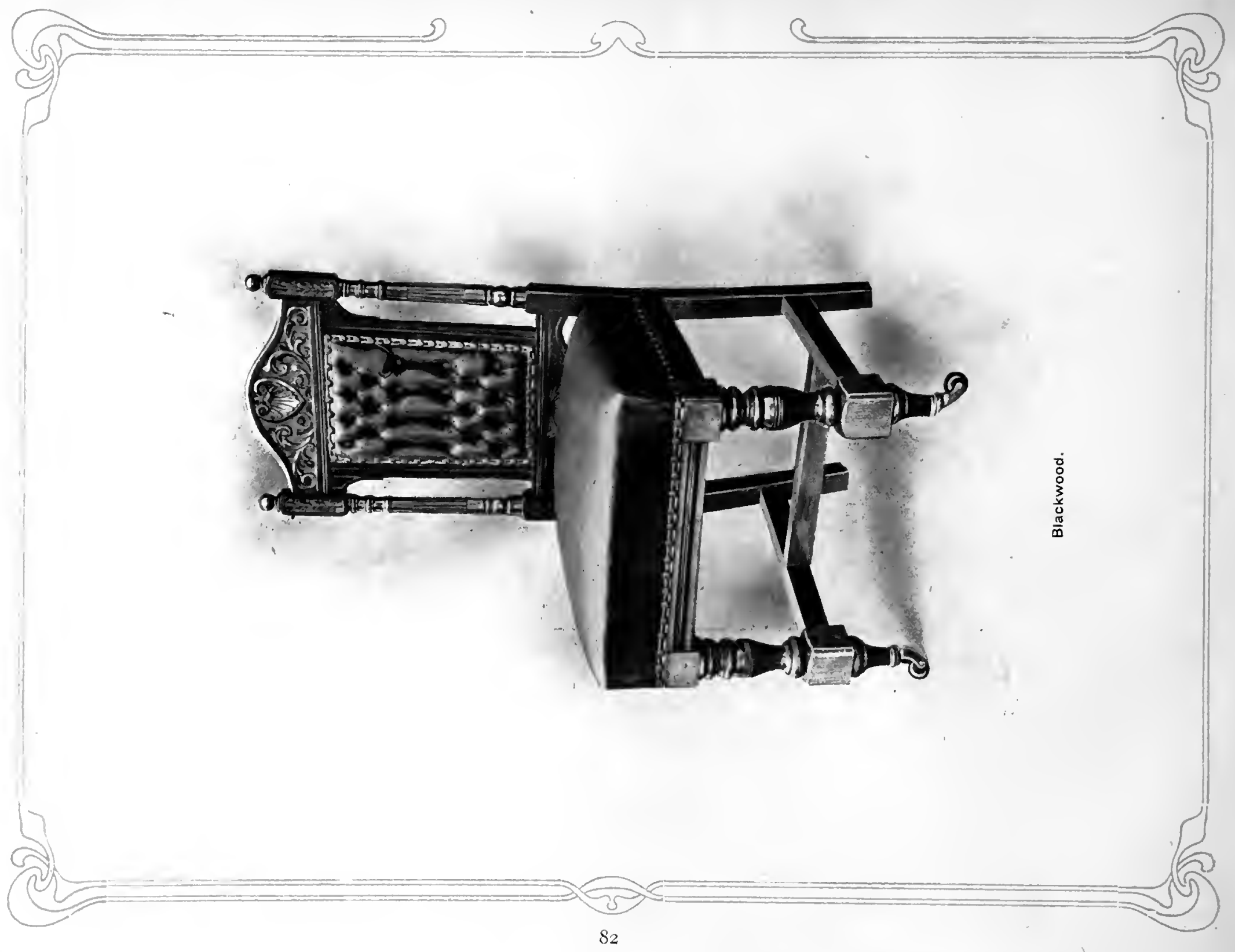



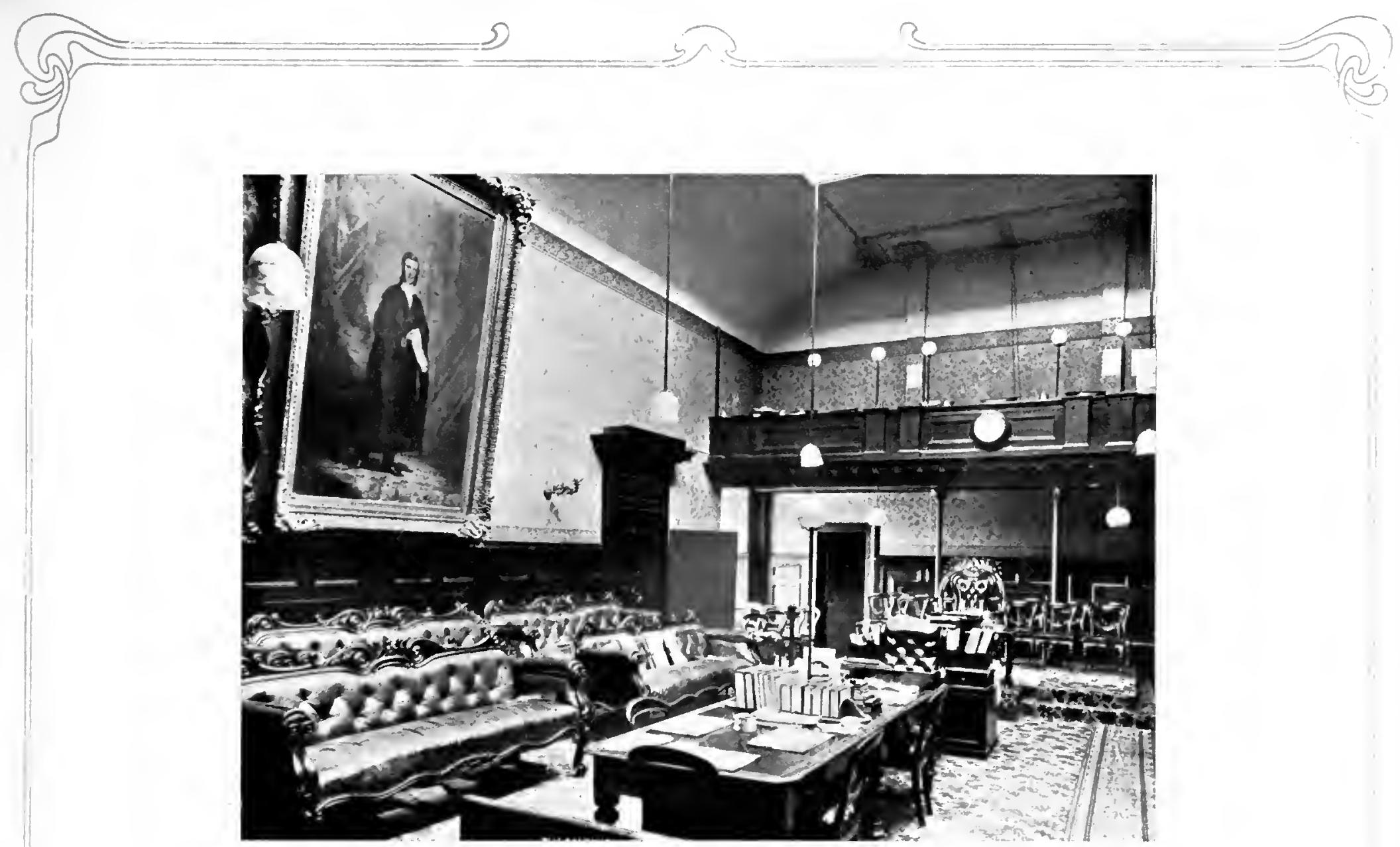

Blackwood and Cedar.

House of Assembly, Hobart. 


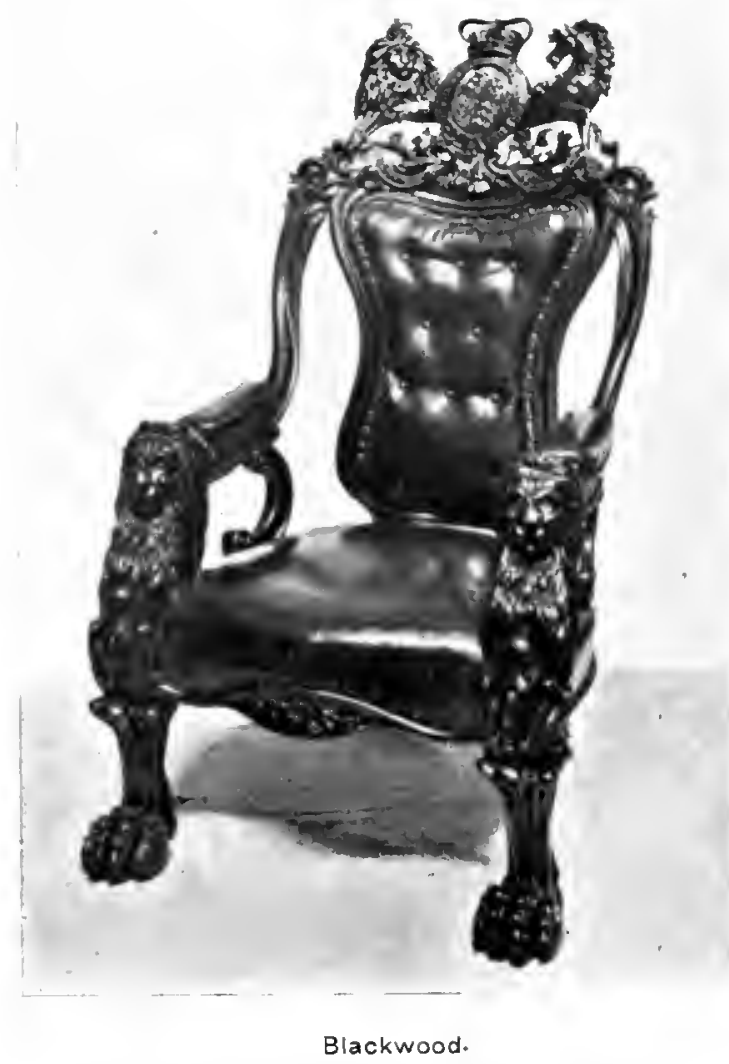

President's Chair, Legislative Council, Tasmania.

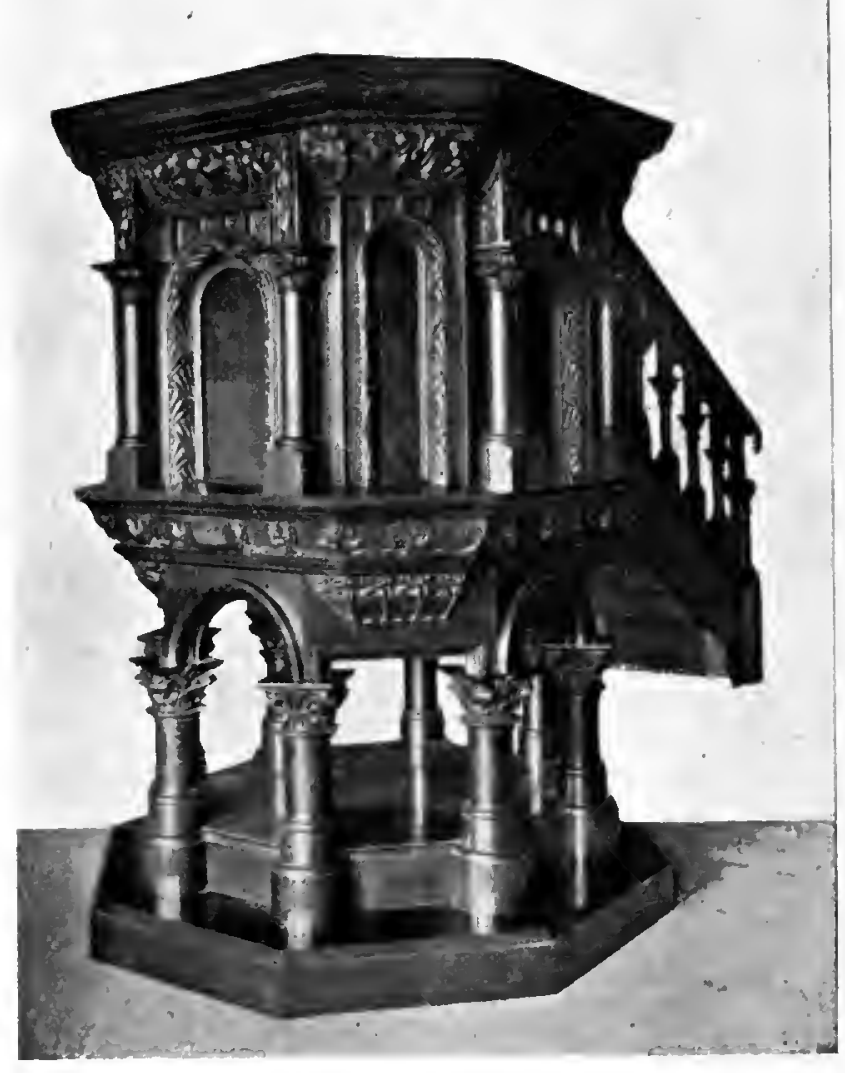

Blackwood Pulpit.

R.C. Church, Malvern, Melbourne. 


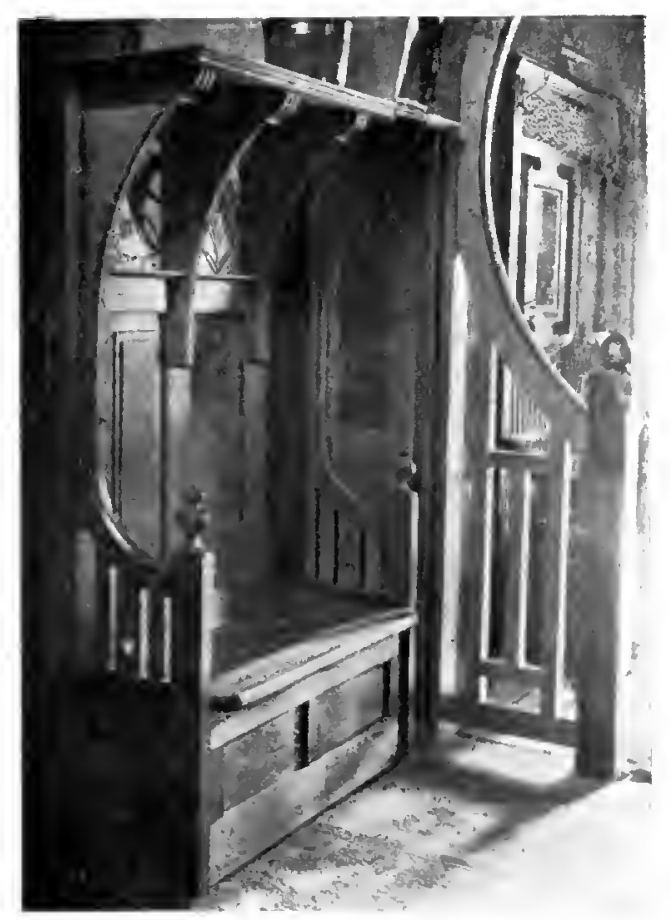

Blackwood Settee.

C. B. Brady's Residence, Launceston.

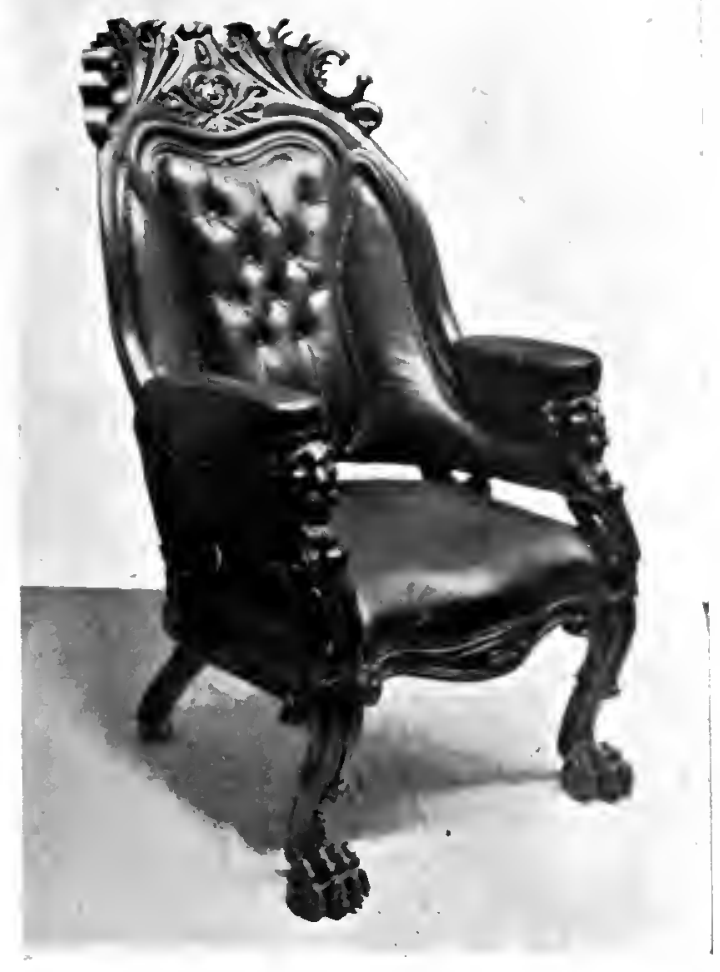

Blackwood.

Speaker's Chair, Tasmanian Assembly. 


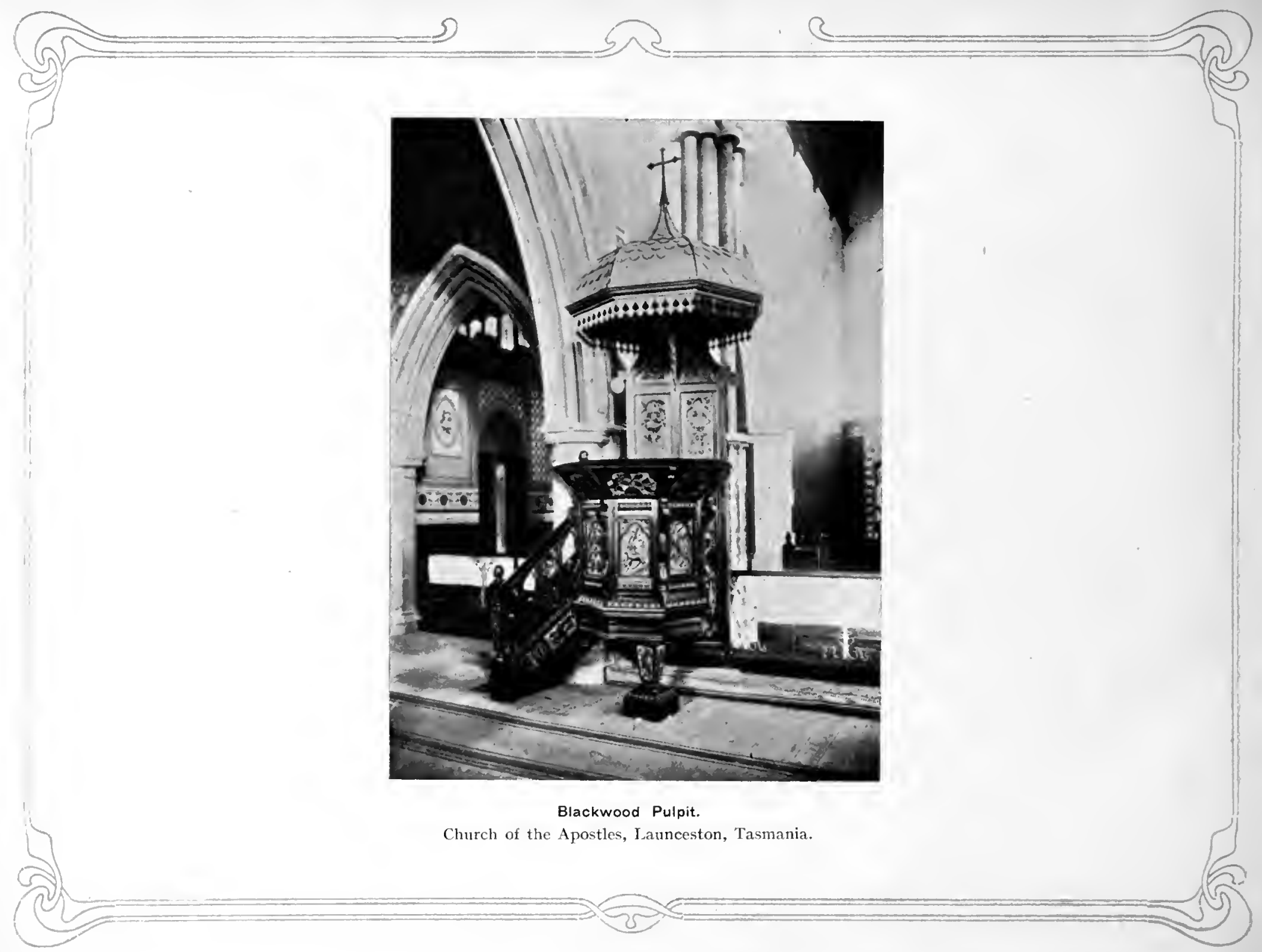




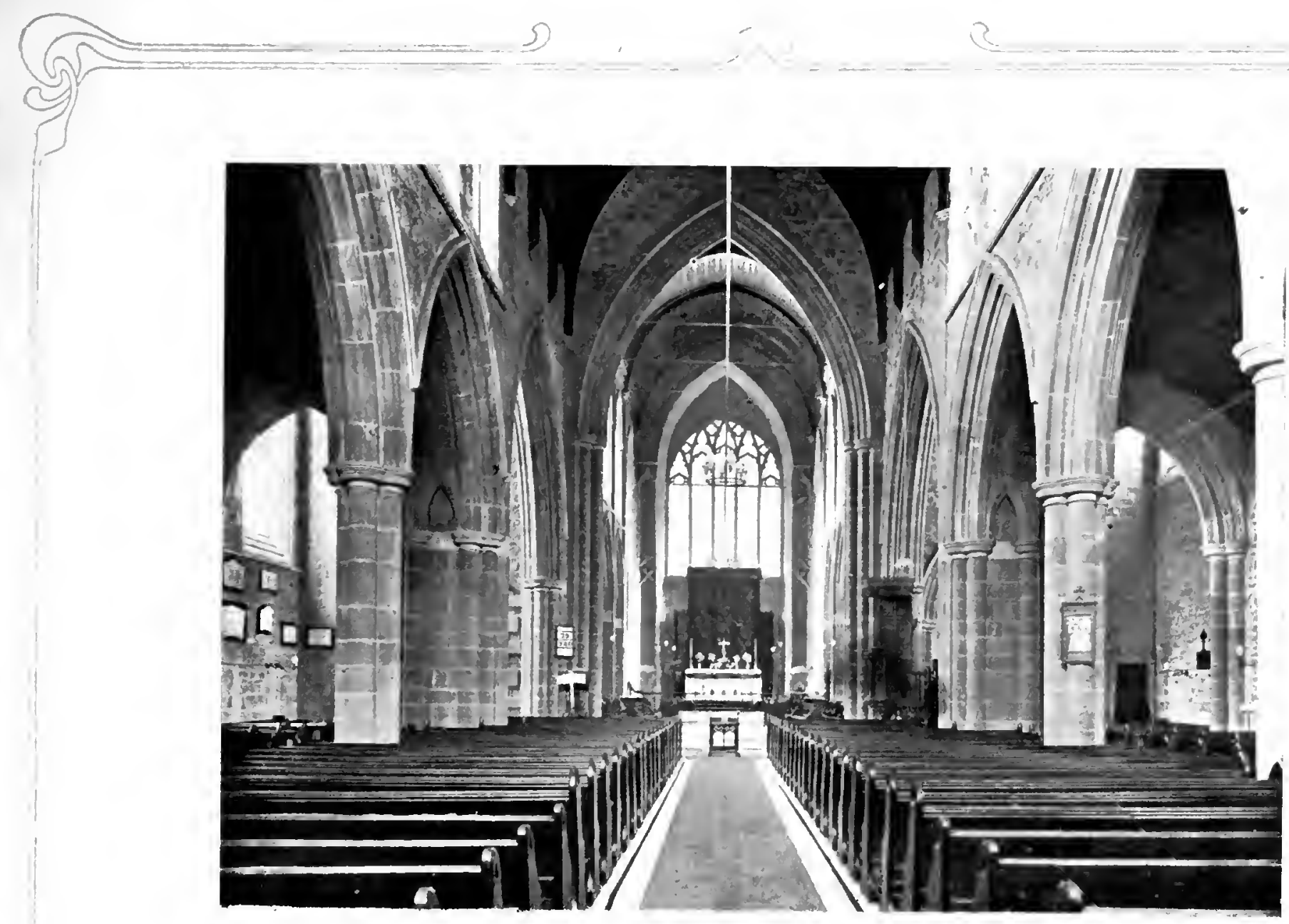

Blackwood Pews.

St. David's Cathedral, Hobart.
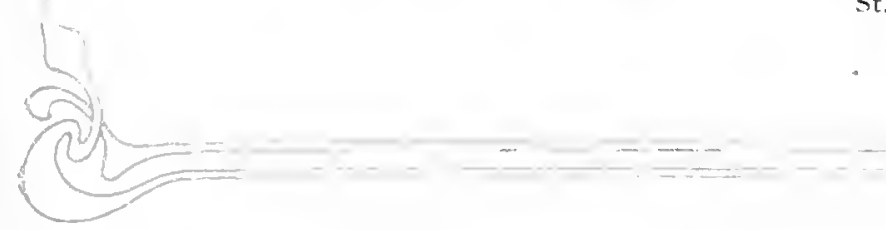


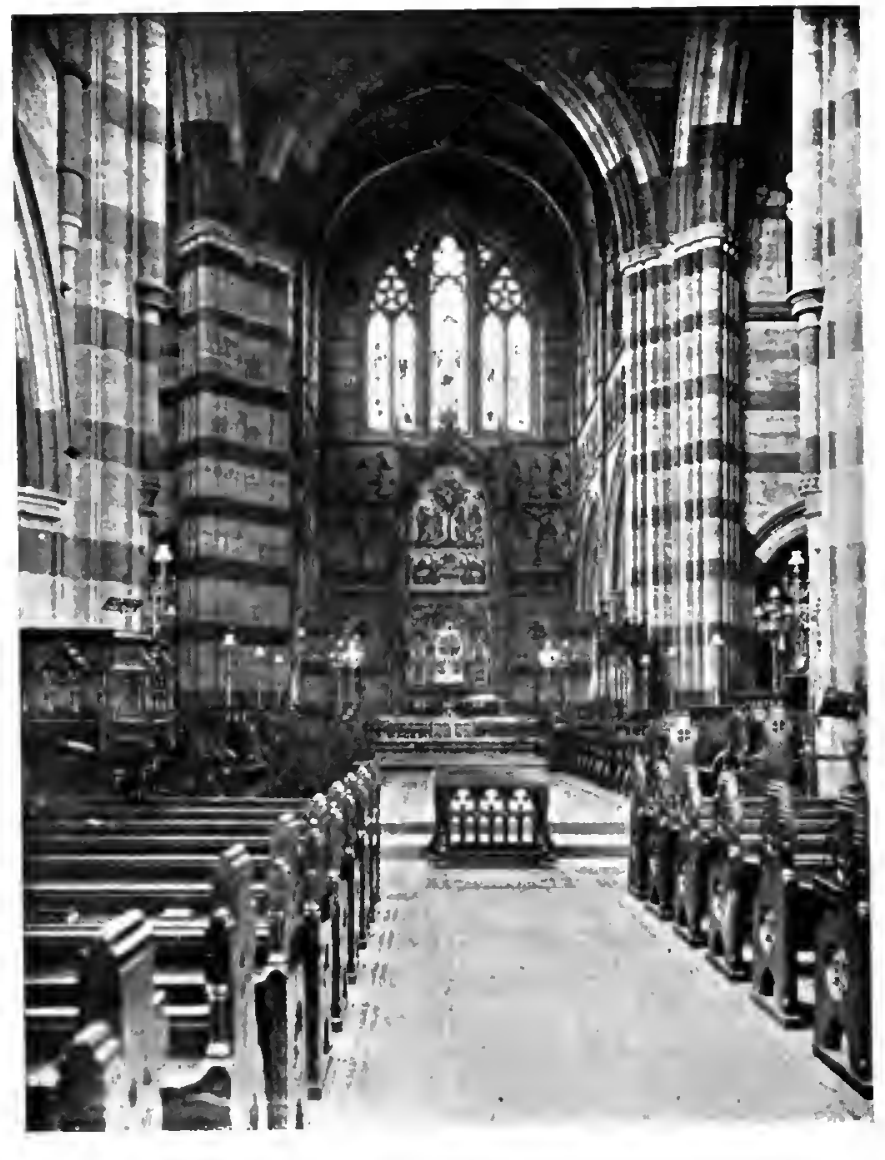

Blackwood.

st. Paunl's cathexlral, AteHbonrmo.

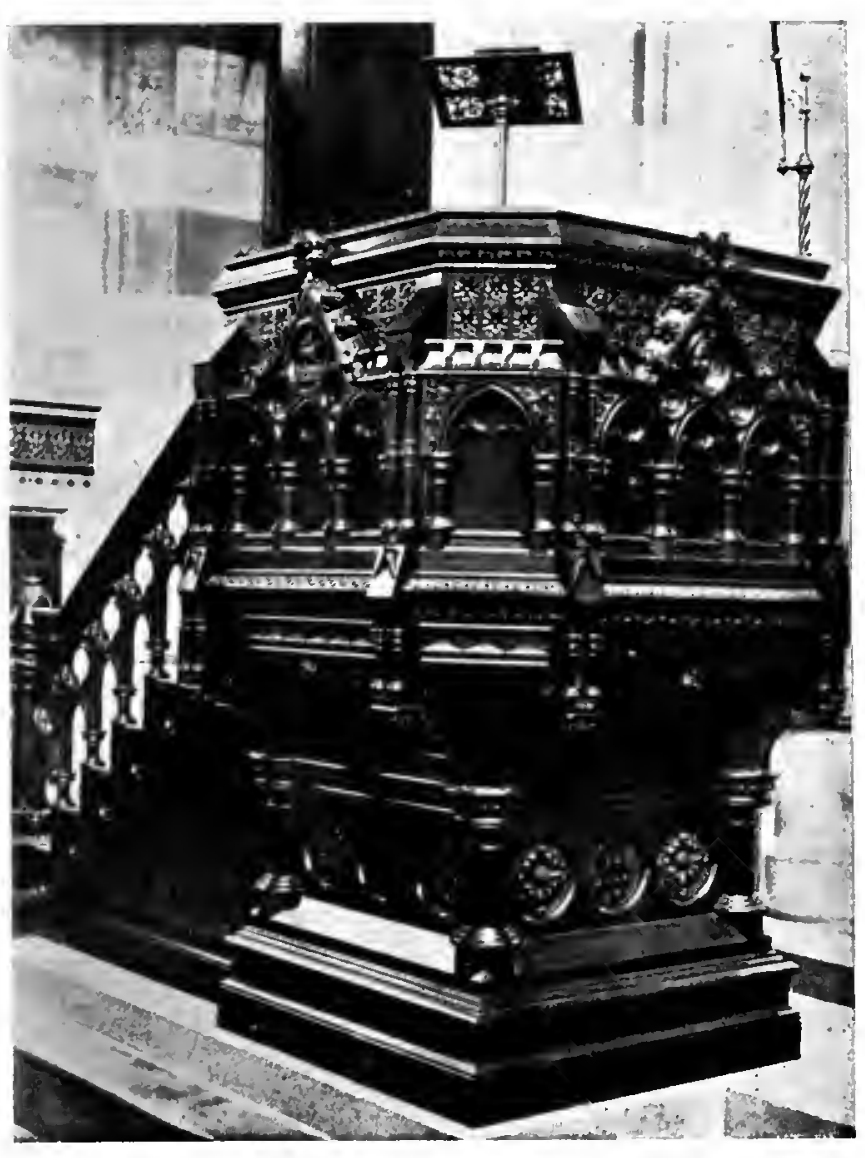

Blackwood Pulpit.

St. Paul's Cathelral, Melbourne. 


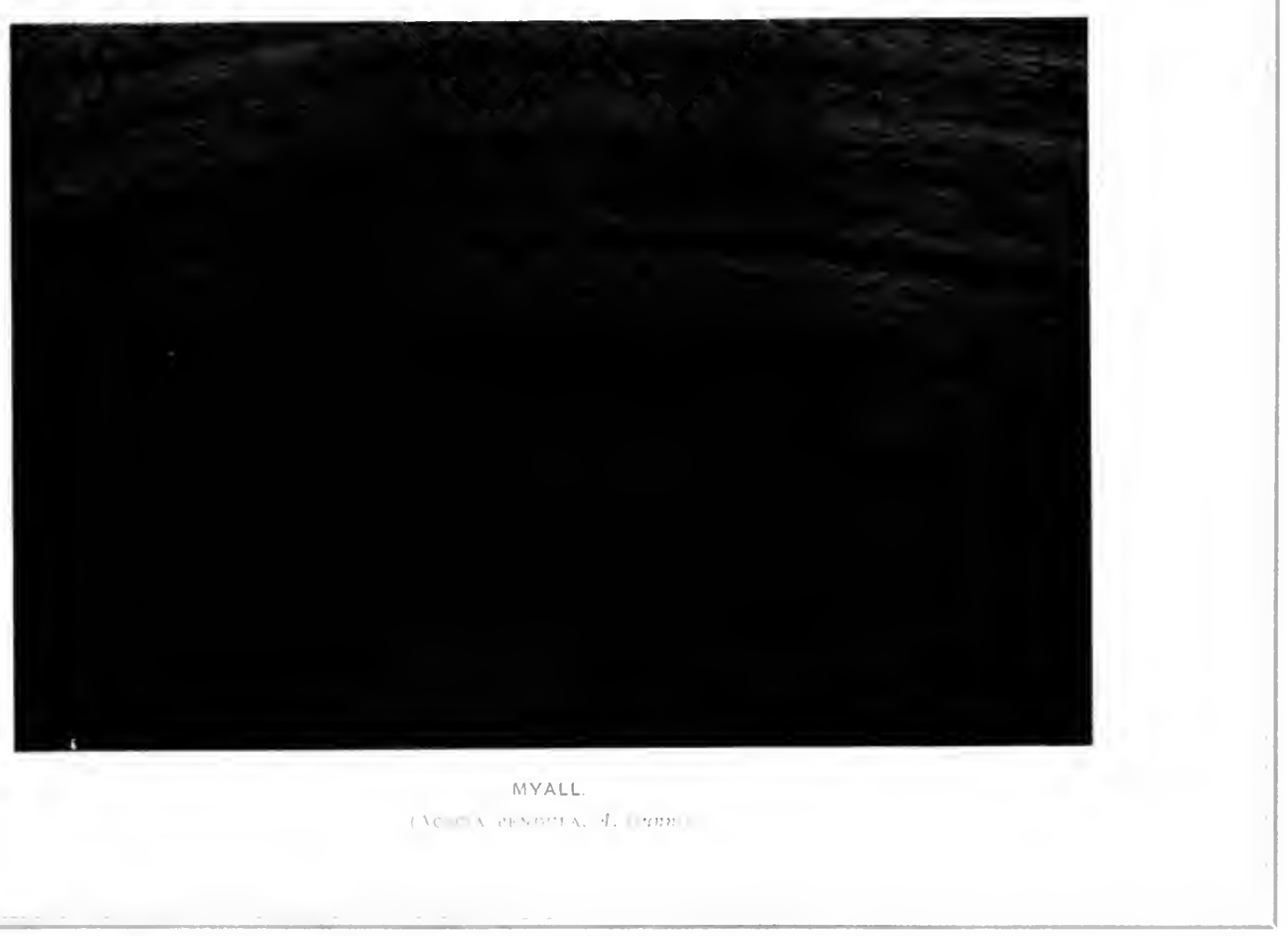




\section{Myall.}

(Acacia pendula, A. Cunn.)

This is one of the hardest and heaviest of the Acacia timbers, and is only suitable for dark heavy furniture, being in this feature a rival to the famous black Oak of the Old Country, so much in vogue in the $I_{5}$ th and I6th centuries, and even later. It is close in texture, not too distinctly figured, polishes and turns well; it could also be utilised for all kinds of small ornamental articles, such as cutlery cases, \&c., and would have a very rich appearance if mounted with silver.

Description of the Tree.-An Acacia which attains tree size and is easily distinguished by its willowy character, which gives it an attractive appearance; branchlets slightly angular, soon terete. Phyllodia of a glaucous hue, linear lanceolate, falcate, acuminate, narrowed towards the base, 2 to 3 inches long, coriaceous, indistinctly finely striate, often with a recurved point. Inflorescence in short axillary racemes, each head containing from twelve to twenty flowers. Pod linear, very flat, nearly 3 inches long and 3 inch broad, the valves reticulate, the sutures bordered by a very narrow wing. Seeds oval, placed obliquely; arillus with three or four short folds near the hilum.

Geographical Range.-From the Maranoa River, Queensland, to morasses of the Lachlan and Western Plains New South Wales. 


\section{Brigalow. (Acacia harpo}

Brigalow trees differ in one respect from many of their congeners, as they are gregarious, and the term Brigalow scrub is common over a fair area of the States of New South Wales and Queensland. The timber is dark-coloured, hard, heavy, and suitable for heavy work of a smaller size, as only on rare occasions does it reach large dimensions. The remarks concerning Myall are also applicable to this timber.

Description of the Tree.-A fair-sized tree found well to the west of the Eastern Coast Range, with a hard, compact, furrowed bark. Phyllodia pale or glaucous, varying in length from 3 to 9 inches, narrowed at both ends, coriaceous, pale or glaucous, with several veins fairly well marked. Inflorescence in axillary clusters with slender peduncles under I inch long, the globular head of flowers containing about twelve to fifteen flowers. Pods narrow, under 6 inches long, constricted between the seeds, oval ; arillus short and straight.

Geographical Range.-Abundant on the barren heaths of the interior from the Lachlan River to the Barrier Range ; also in Victoria. 


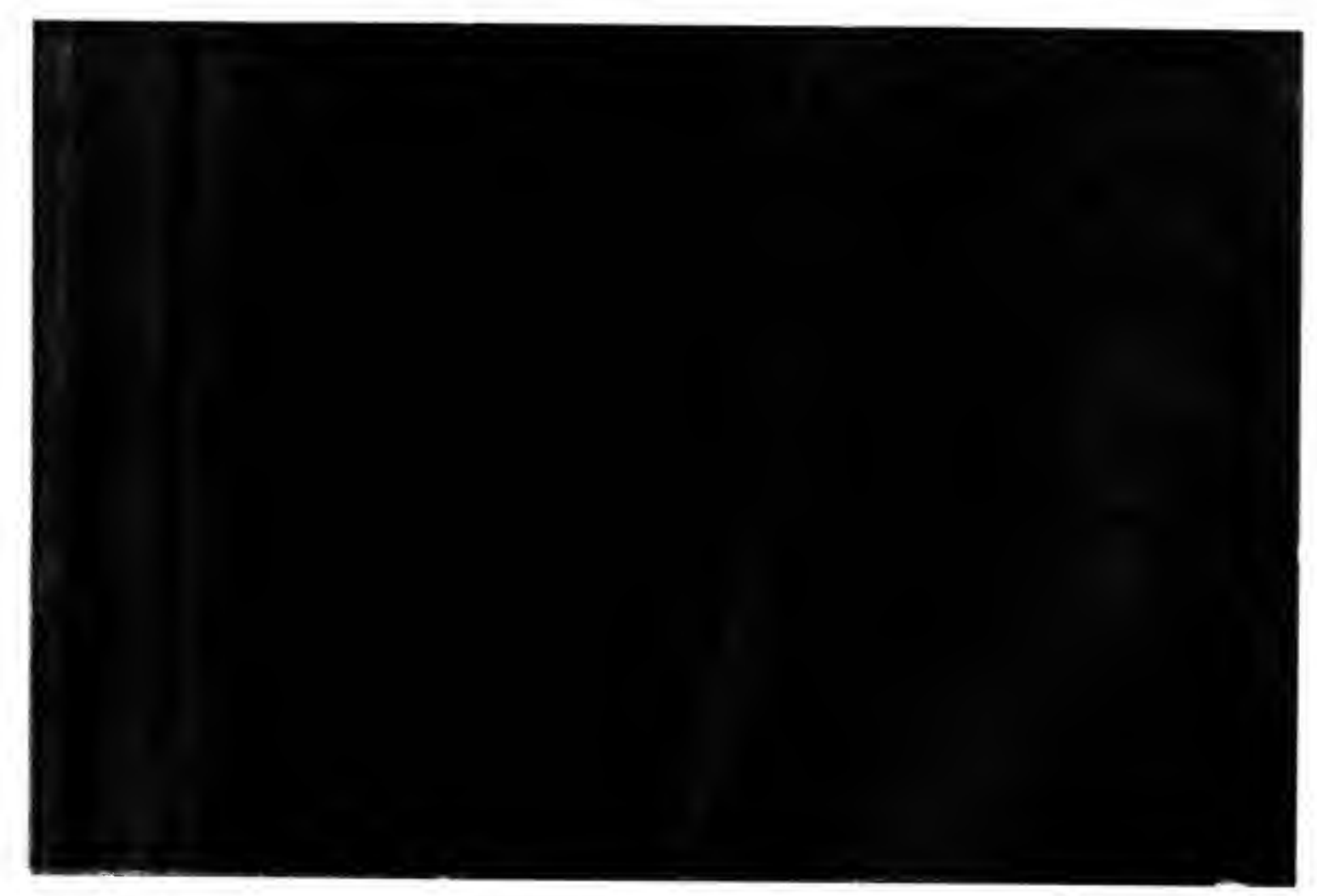

BRIGALOW.

hareó 


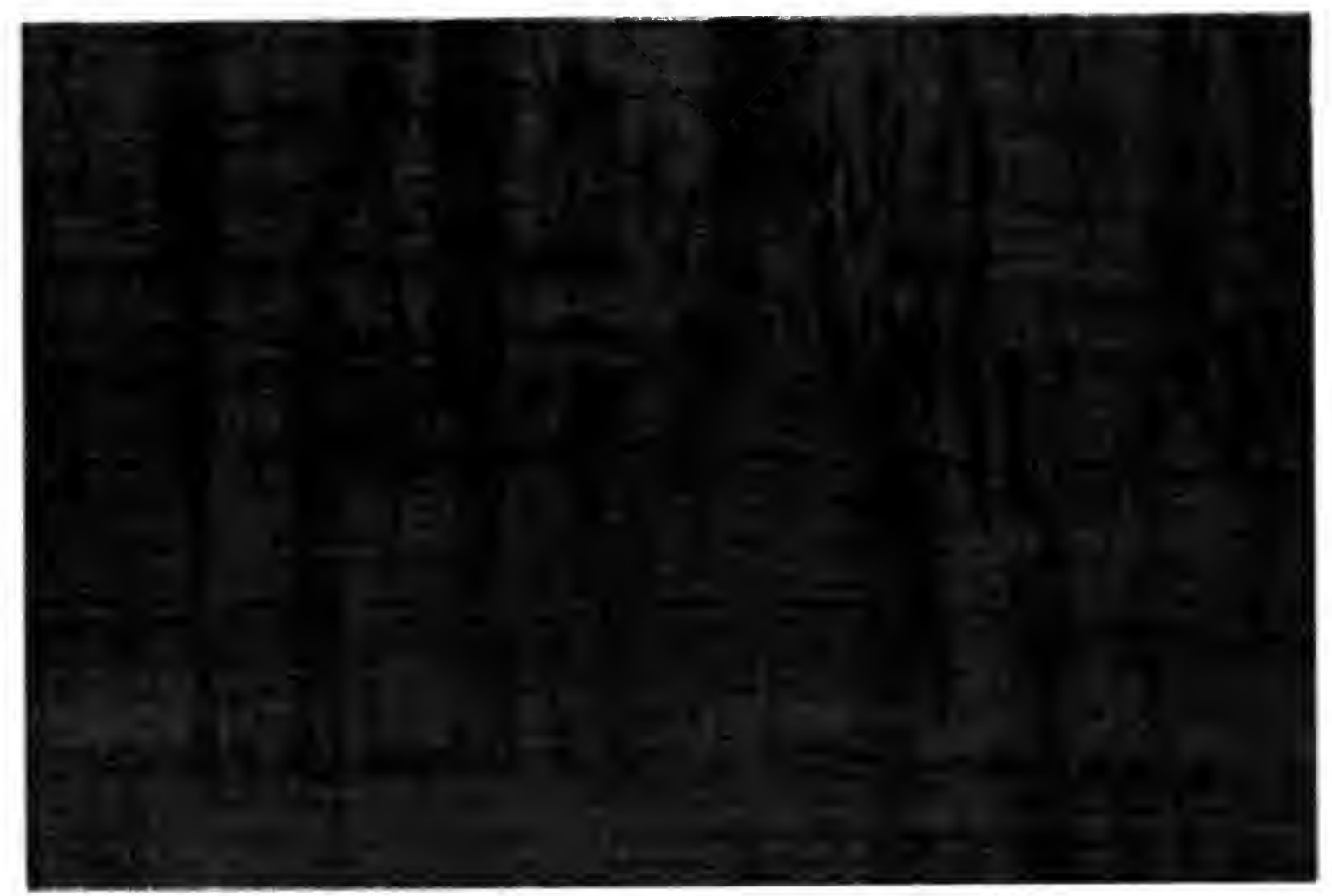

RING GIDGEA.

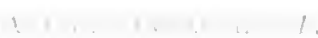




\section{Gidgea.}

\section{(Acacia Cambagei, R.T.B.)}

Like most Acacias of the interior, the timber is very dark coloured, close grained, and heavy. When the fibres are interlocked or cross grained, it is then known as "ringed Gidgea," and this is in great request for turnery, for then the wavy appearance of the wood produces a pretty figure, the undulations of light and shade being very effective. For this reason it is much in request for walking sticks, table legs, balusters, newel posts, \&c. When the late Sir George Dibbs was in "durance vile," for conscience' sake, he turned a walking stick, and presented it to King Edward VII, who graciously accepted it. The result of this little exchange of courtesy was that the Museum was inundated with letters from Home from walking-stick makers desiring to be supplied with timber of Ring Gidgea. This ring character is found to obtain in other Australian woods. The straight grained timber would be very suitable for heavy cabinet work, and other solid specimens of Applied Art. In the Western area of New South Wales, especially at Bourke and beyond, it is fairly plentiful, and forms the principal fuel where coal is scarce.

Description of the Tree.-A medium-sized tree with pendulous branchlets, the foliage of a pale or glaucous hue; branchlets angular; phyllodia falcate, lanceolate, obtuse or slightly acuminate, up to 5 inches long, and from 5 to 9 lines broad, with numerous fine parallel veins, two or three more prominent than the rest, thin or membraneous. Peduncles about 3 lines long, slender in axillary clusters of about six, each bearing a globular head of about twelve flowers. Sepals broad, spathulate, ciliate on the upper edge, free, and less than half as long as the petals. Petals glabrous. Pod flat, straight, about 3 lines long and 4 lines broad, veined, valves thin, not contracted between the seeds. Seeds ovate, longitudinal, or slightly oblique, funicle short, filiform, not folded nor dilated.

Geographical Range.-Interior of New South Wales and Queensland. 


\section{Tortoise Shell Tulip.}

(Pithecolobium Hendersoni, F.v.M.)

The greatest recommendation in this timber is the fine figure and colour of its grain, the latter being a mixture of pink and yellow, and these are further enhanced by polishing. It is a light, soft timber, with a sap wood which must be removed, as it is liable to the attacks of borers, therefore only the duramen can be used for cabinet work. It planes well, and has a free and open grain, and looks handsome polished. It is suitable for any kind of internal decoration, such as railway and elevator cars, fancy ornamental boxes, cabinets, trays, \&c.

Description of the Tree.-A fair-sized tree of the brush lands of the Coast, with a thin, comparatively smooth, bark. Leaves consisting of pinnæ from one to two; leaflets, four to six, oblique, sessile, without any gland but one at the junction of the pinnæ. Flowers large, sessile, in globular heads. Corolla about $\frac{3}{4}$ inch long. Stamens about I $\frac{1}{2}$ inches long, greenish-white. Pods curved, $\frac{1}{2}$. to $\mathrm{I}$ inch broad, outer margin undulate, deep red inside. Seeds black, shining. districts.

Geographical Range.-Southern Queensland and Northern New South Wales Coast 


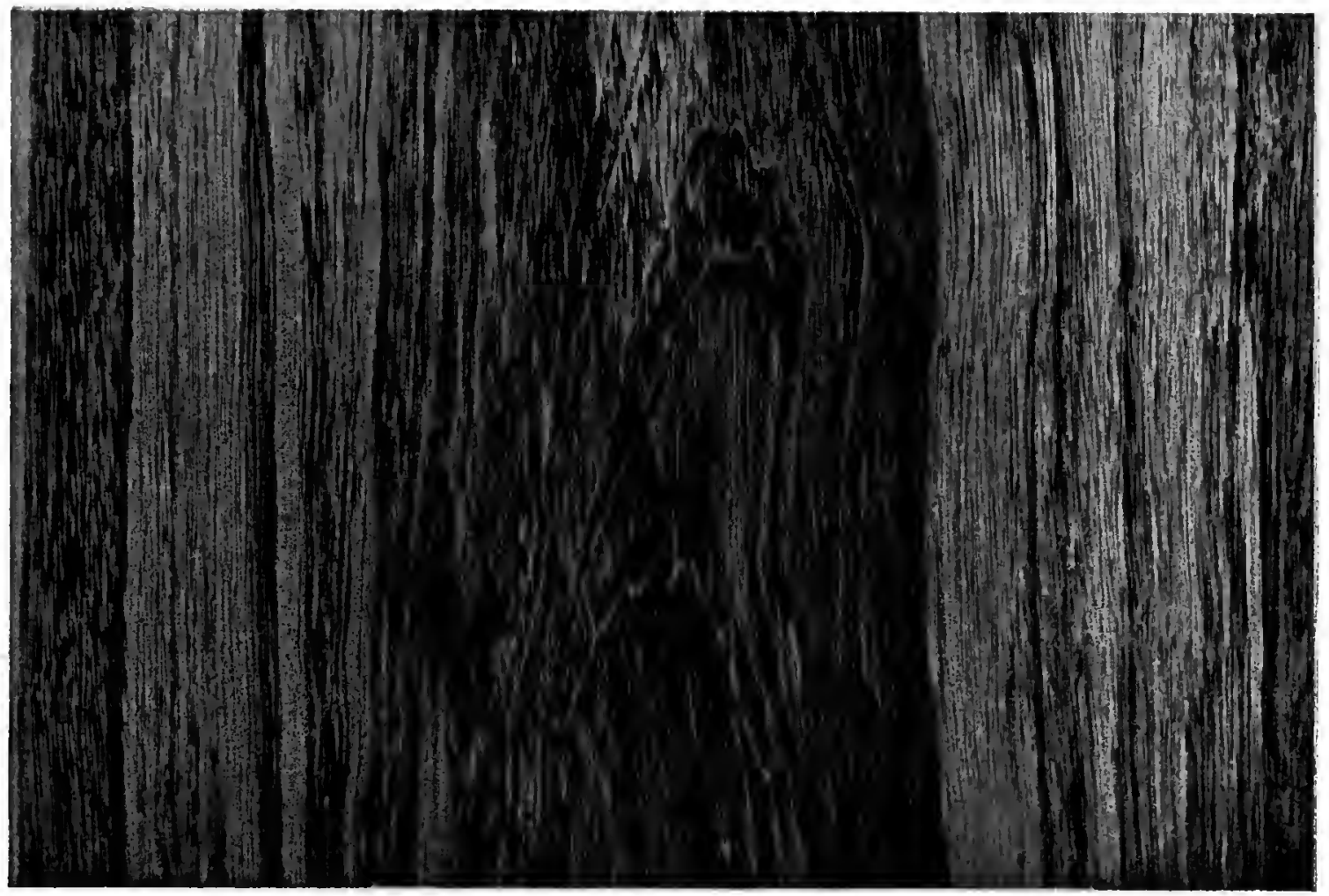

TORTOISE SHELL TULIP.

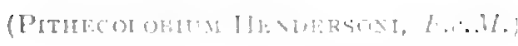


$\cdot$ 
NATURAL ORDEF.

\section{SAXIFRAGE $Æ$.}

* $x$

THE representatives of this world-wide Order occur in almost every State of the Commonwealth, and range in size from a small herbaceous annual to a fair-sized forest tree. The principal Australian timbers in this connection are :-

Coachwood (Ceratopetalum apetalum, D. Don).

Corkwood (Ackama Muelleri, Benth.).

(Weinmannia rubifolia, F.v.M.).

Plumwood (Eucryphia Moorei, F.v.Ml.).

Coachwood is a first-class timber, and the supply is plentiful, but the wood is not appreciated so much to-day as previously. Coachwood's day will yet come in Australian cabinet work.

Species Illustrated in Colour :-

Coachwood (Ceratopetalum apetalum, D. Don).

Corkwood (Ackama Muelleri, Benth.). 


\section{Coachwood.}

(Ceratopetalum apetalum, D. Don.)

This timber, often known also as "Leatherjacket," was one of the earliest used in coachbuilding, but is not much employed now, although the reason for its being discarded is not obvious. It is a timber that is readily differentiated from others, being characterised by a sweet perfume, named by chemists as Courmarin. This feature should be known by the trade, as other timbers are sometimes sold for Coachwood, but the odour test is an infallible one. It is fairly light in weight, and has a colour inclining to pale pink. The figure is marked, and sometimes ornamental. It takes a splendid polish, is easily worked, and strong, and it is difficult to explain how its utilisation in the cabinet trade is neglected. It has been used for gun stocks, broom heads, bodies of buggies, and can be bent to any shape required. It should be very useful for chair-making, or for any purpose where a light, tough timber is required. Some regard it as a good substitute for English Ash, and not very inferior to American Hickory. The late Sir William Macarthur exhibited in the London Exhibition, I85I, a table of it, made in Paris from wood taken home by himself. This piece of furniture is now at Camden Park, and demonstrates what a splendid timber it is for this purpose.

Description of the Tree.-A beautiful, fragrant tree, found in the Mountains and East Coast district, having a smooth, whitish, hard bark, attaining a height of about 60 feet or more. Leaflets usually solitary, only occasionally found in threes in early growth, up to 12 inches long, but commonly under 6 inches, ovate, lanceolate, obtusely serrate, sometimes shining, reticulations well marked on under side, articulate on a petiole of $\frac{1}{2}$ to $I$ inch long. Flowers numerous in terminal dense corymbose cymes or panicles, usually shorter than the last leaves. Petals, none. Calyx-lobes acute, about $\frac{1}{8}$ inch in flower and $\frac{1}{4}$ inch long in fruit.

Geographical Range.-Common in all the brushes of the East Coast. 


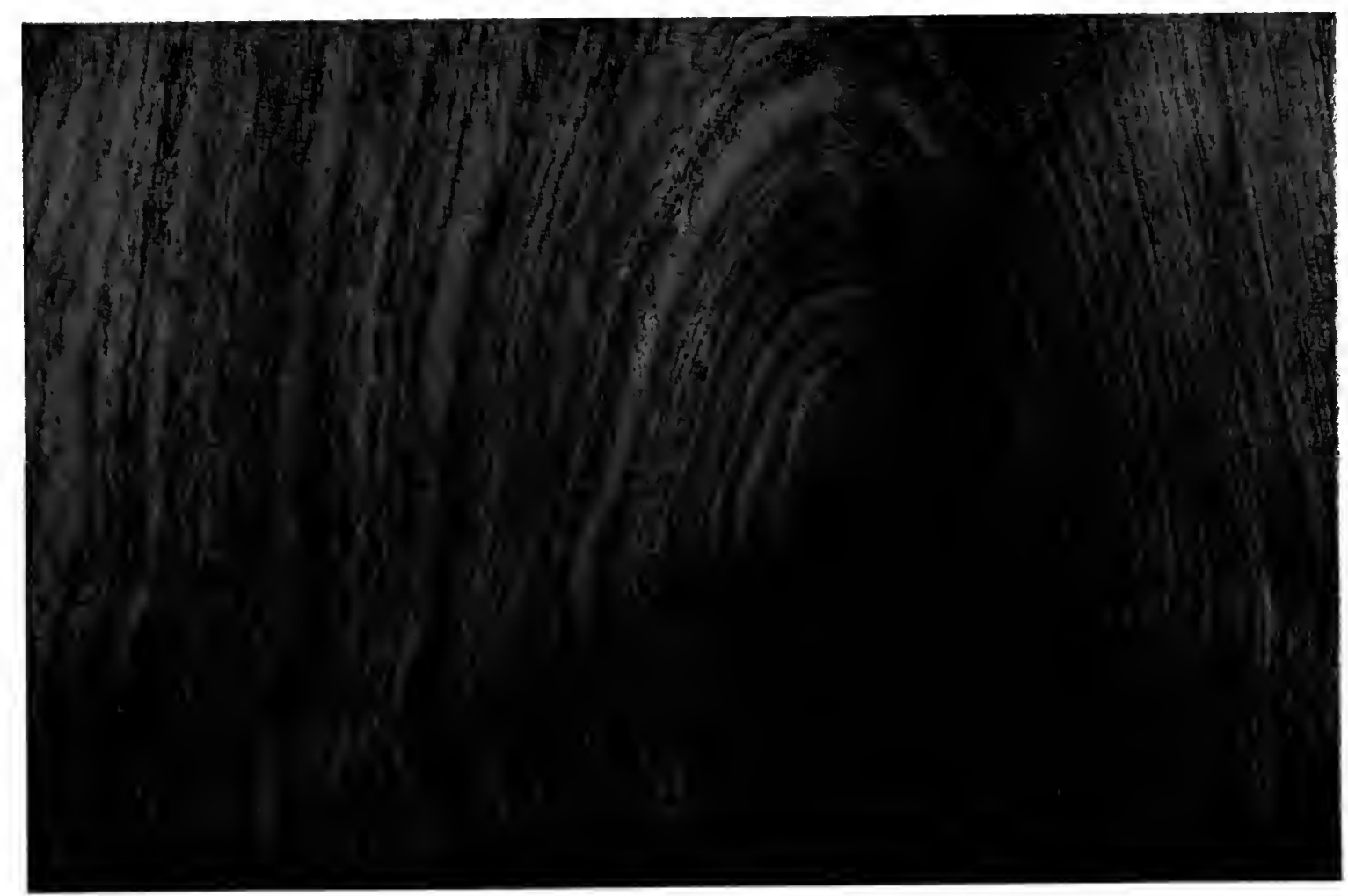

COACHWOOD.

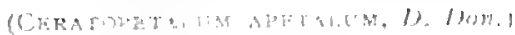




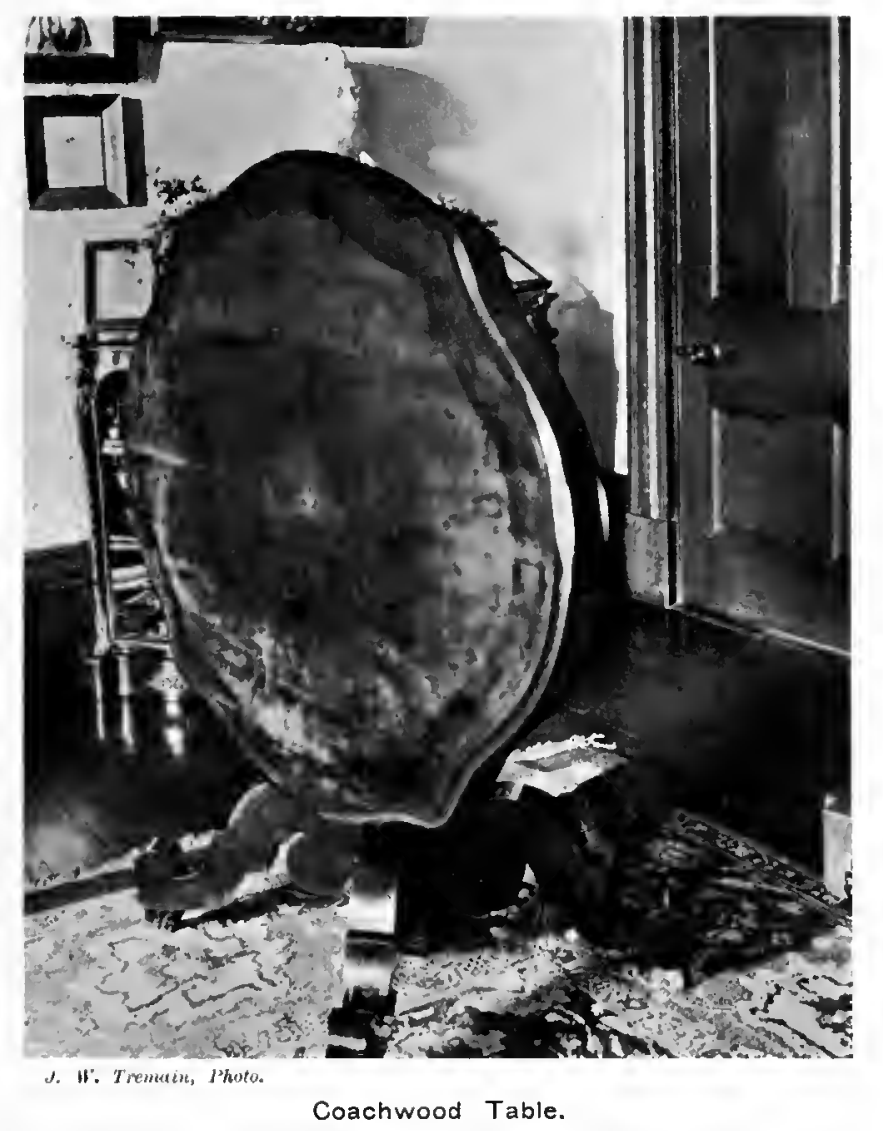

Camden House, N.S.W. (Exhibited at the International Exhibition, I851.) 


\section{Corkwood.}

\section{(Ackama Muelleri, Benth.)}

It is only occasionally that this timber finds its way into the Sydney market. It is specifically light, very easy to plane, soft, with a close grain, having a small neat figure when cut on the quarter. The colour is a warm chocolate. It is only suitable for indoor work, and even then only when little strength is required. It could be used for the interior decoration of aeroplane taxi-cabs, owing to its lightness and rich red colour, and also for skirtings, mouldings, sashes, and flooring.

Description of the Tree.-An average brush tree, with a slightly corky bark. Leaves opposite, pinnate; leaflets usually five, rarely seven, ovate elliptical, or ovate lanceolate, acuminate, obtusely and very shortly serrate, varying in length up to 9 inches, penniveined, venation well marked on the underside. Domatia present in the axils of the primary veins. Flowers very small, very numerous, in compound panicles in terminal pairs, becoming axillary by the elongation of the central shoot. Fruit a small capsule, turgid, septicidally dehiscent.

Geographical Range.-Scrubs along North Coast Raikway, Queensland, and south to brush forests, Gosford, New South Wales. 
XX.

CORKWOOD.

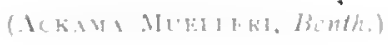


NATURAL ORDER.

\section{MYRTACE $Æ$.}

¿

AN Order fairly well distributed over the world, more particularly in the tropics and warmer parts of the temp, arate zones, and strongly represented in the Australian Flora, especially in the Eucalyptus. Although one of, if not the most prolific producer of timher in Australia. yet as cabinet woods they have not been much in demand, principally owing, in some cases, to the heavy specific gravity. The Jarrah of Western Australia is a cabinet wond of the first class, especially in counters and fittings in commercial houses and offices, and there are many other red woods that conld be used for similar purposes. Amongst pale coloured timbers, (E. Delegatensis) a Mlountain Ash of N.S.II. and (E. obliqua) the Stringybark of Tasmania are now being largely manufactured into furniture, bank, house and office fittings of all kinds, and these make a splenlid substitute for English Oak. Other Stringybarks are worthy of attention in this direction. Besides the Genus Eucalyptus there are other genera suitable for this particular industry, such as Tea Trees (Melaleucu leucudendron and otler species). Lilly Pilly (Eugenia Smithii), and Apple Tree (Angophora sppo).

\section{Species Illustrated in Cololr:-}

Mountain Ash or Tasmanian Oak (Encalyptus Delegatensis, R.T.B.).

Stringybark ( $E$. obliqua, L'Her.).

Red Mahogany (E. resinifera, Sm.).

Jarrah (E. marginata, Sm.).
Red Box (E. Rudderi, J.H.M.).

Spotted Gum (E. maculata, Hook.).

Sydney Blue Gum (E. suligna, Sm.).

Slaty Gum (E. Daresoni, R.T.B.). 


\section{A Mountain Ash or Tasmanian Oak.}

(Eucalyptus Delegatensis, R.T.B.)

A straight-grained, fissile timber with the general facies of English Ash when first cut, but tones down in colour, when it acquires quite an Oak appearance. It planes well, and is specifically on the light side, is strong, with a good resilience; a first class bending timber, and does not warp if carefully seasoned.

The tree is a quick grower, and so is one of the best for forest cultivation.

It is a splendid furniture timber, and is extensively manufactured into various articles in this connection in Tasmania, where it is also used for Church decoration such as carved screens, office fittings, panelling, \&c.

The original common name of Ash is now being superseded by that of Oak, as manufactured articles have a great resemblance to that timber, and are exported under the name of "Tasmanian Oak."

Description of the Tree. - lt is a very fine specimen of the forest giant, with a stringybark stem and smooth branches, and glaucous branchlets. The leaves are fairly large in size. of the usual lanceolate. oblique shape pertaining to the Genus. often glaucous, with a well marked venation-the lateral veins forming an acute angle with the midrib. They are quite aromatic when kept in a closed box. The buds are numerous in axillary peduncles, operculum hemispherical, depressed. The frnits are variable in shape, ranging from hemispherical in some Tasmanian forms to oval-pyriform in the New South Wales species; rim truncate, slightly domed or countersunk, under $\frac{1}{2}$ inch lung.

Geographical Range.-South-east highlands of New South Wales and Victoria, and the highlands of Tasmania, where it is known in the field as "Gum-topped Stringybark." 
$\mathrm{XXX}$

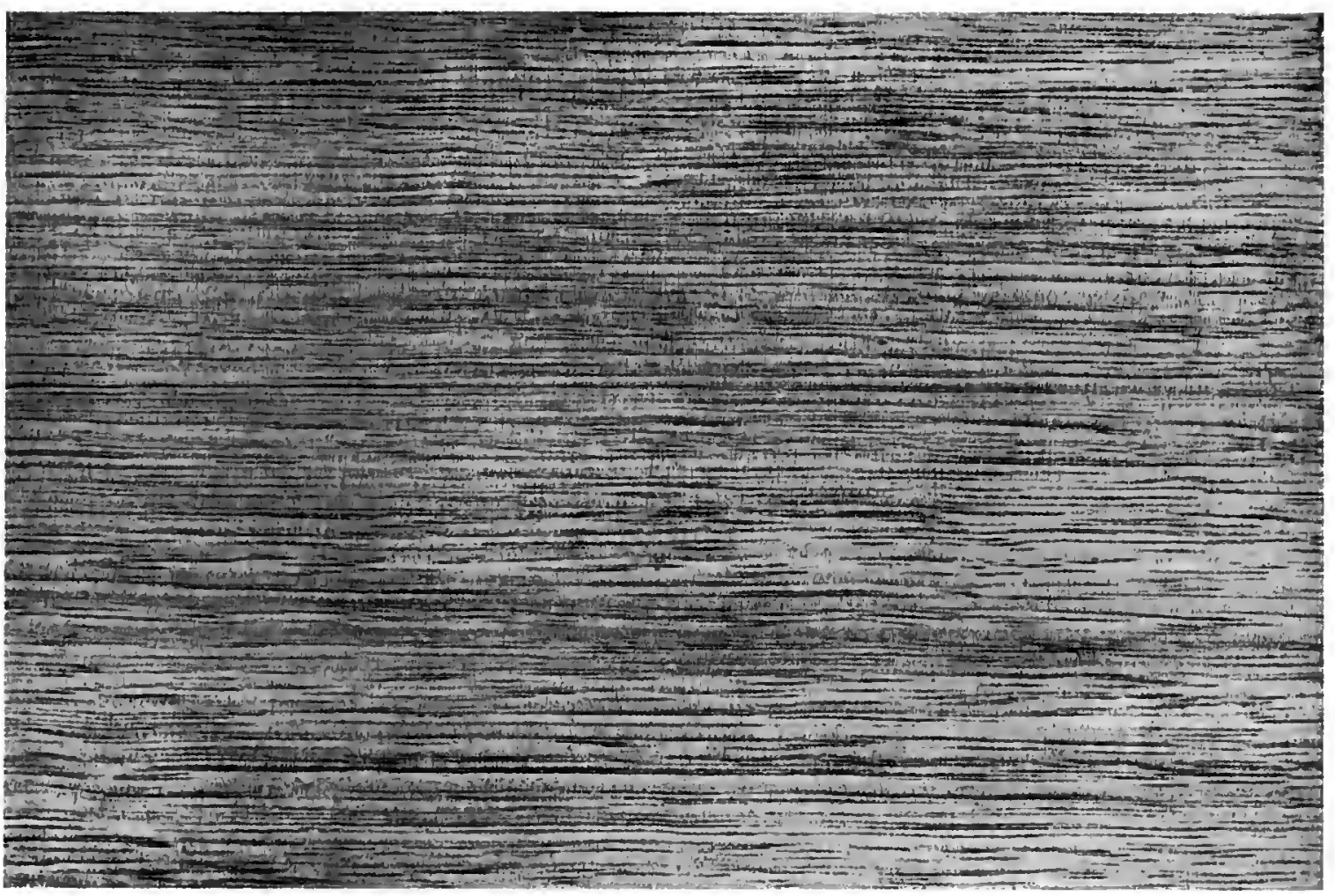

A N.S.W. MOUNTAIN ASH OR TASMANIAN OAK

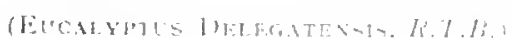




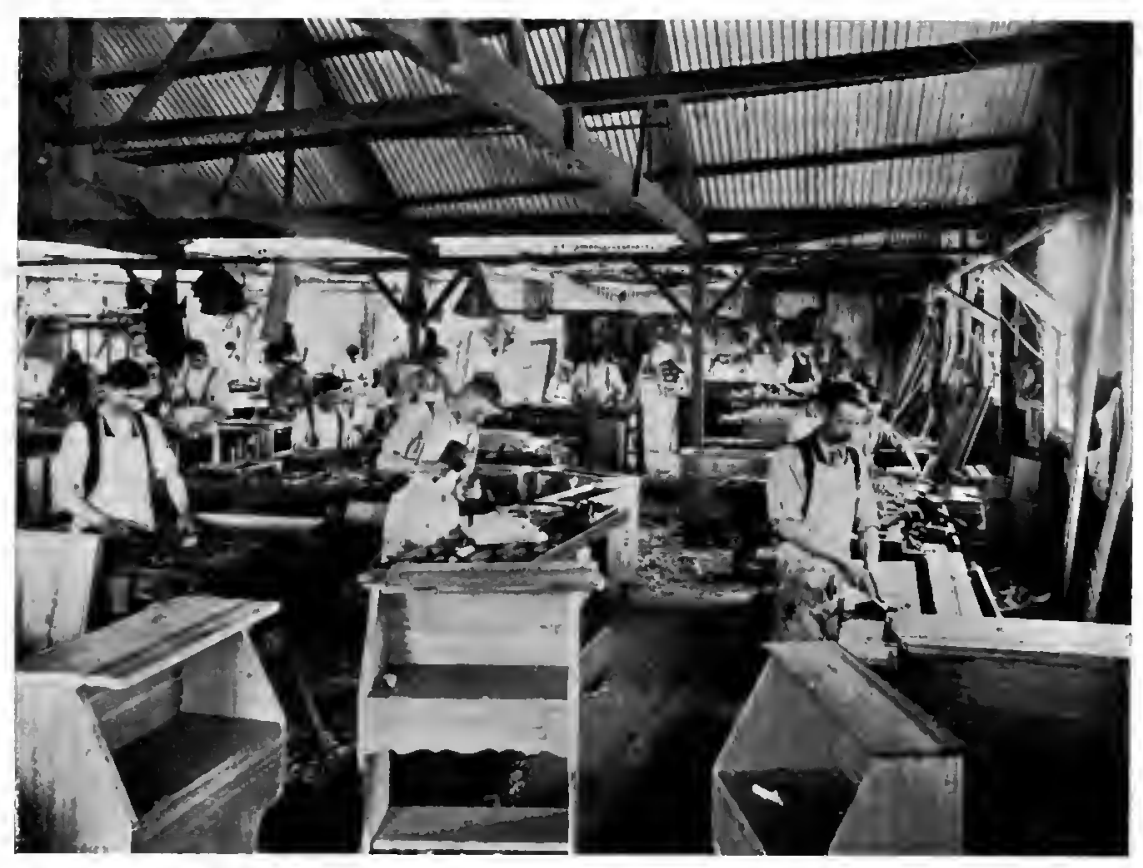

Manufacturing Furniture from Tasmanian Oak and Stringybark, Launceston. 


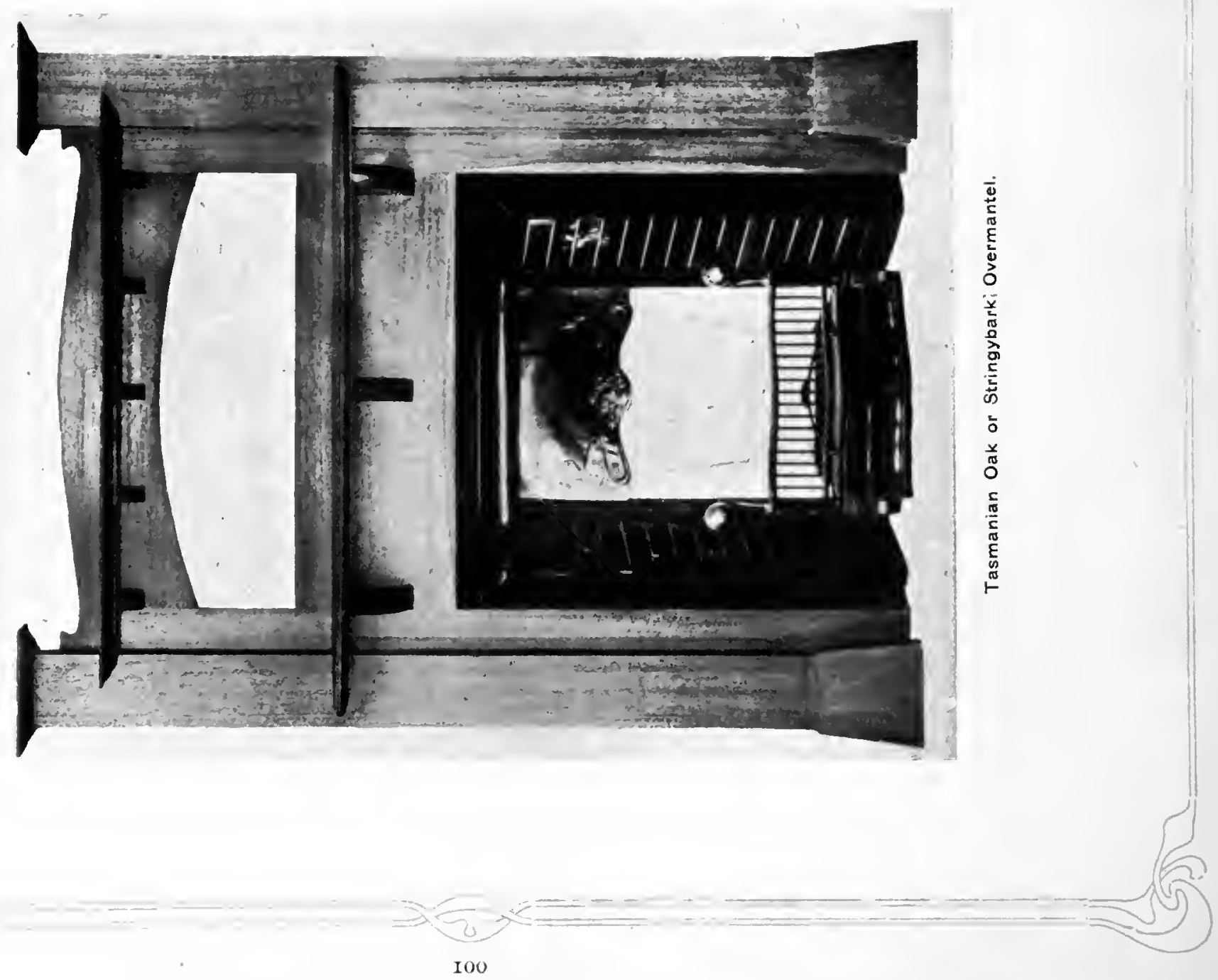




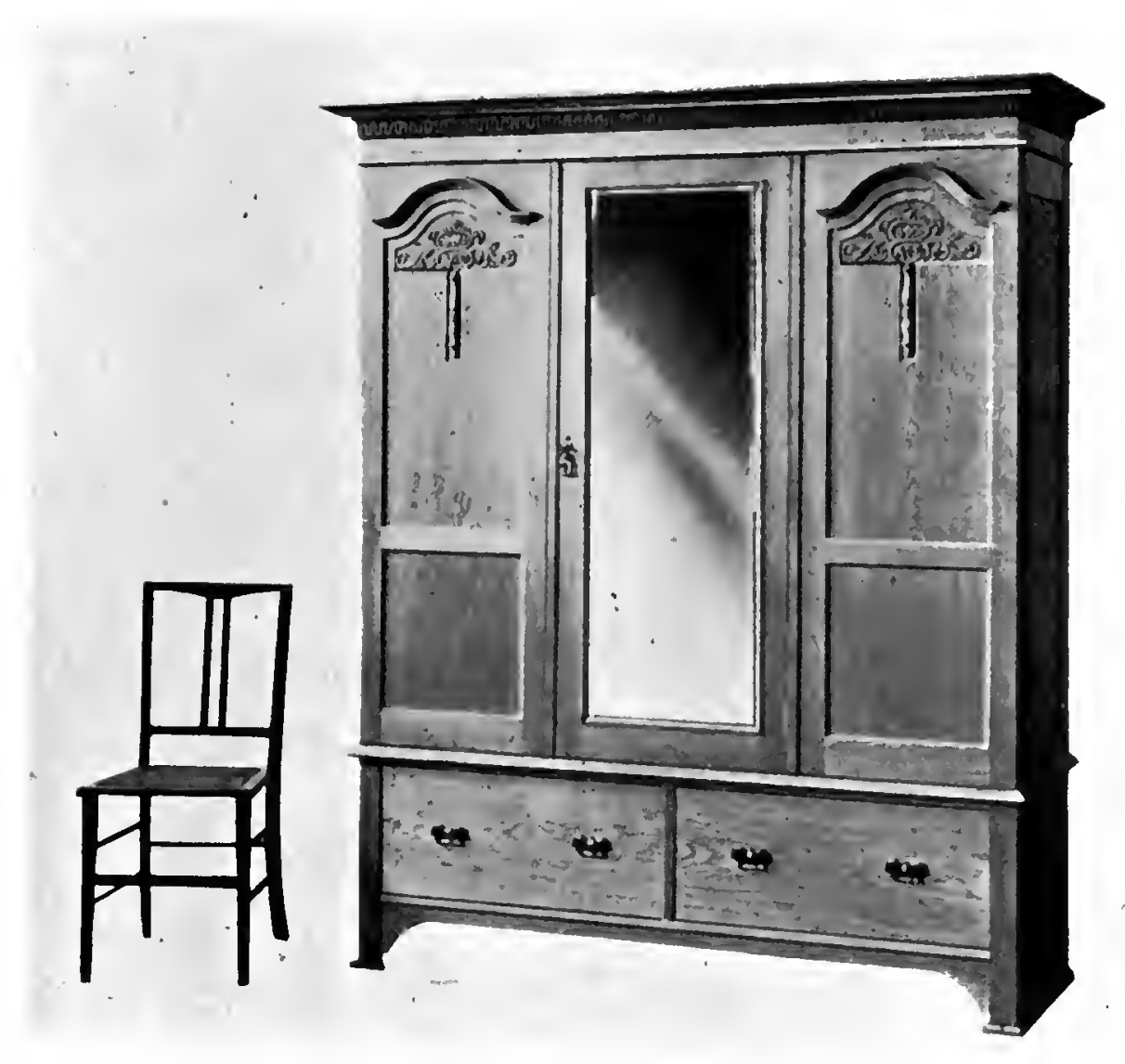

A N.S.W. Mountain Ash Wardrobe. 

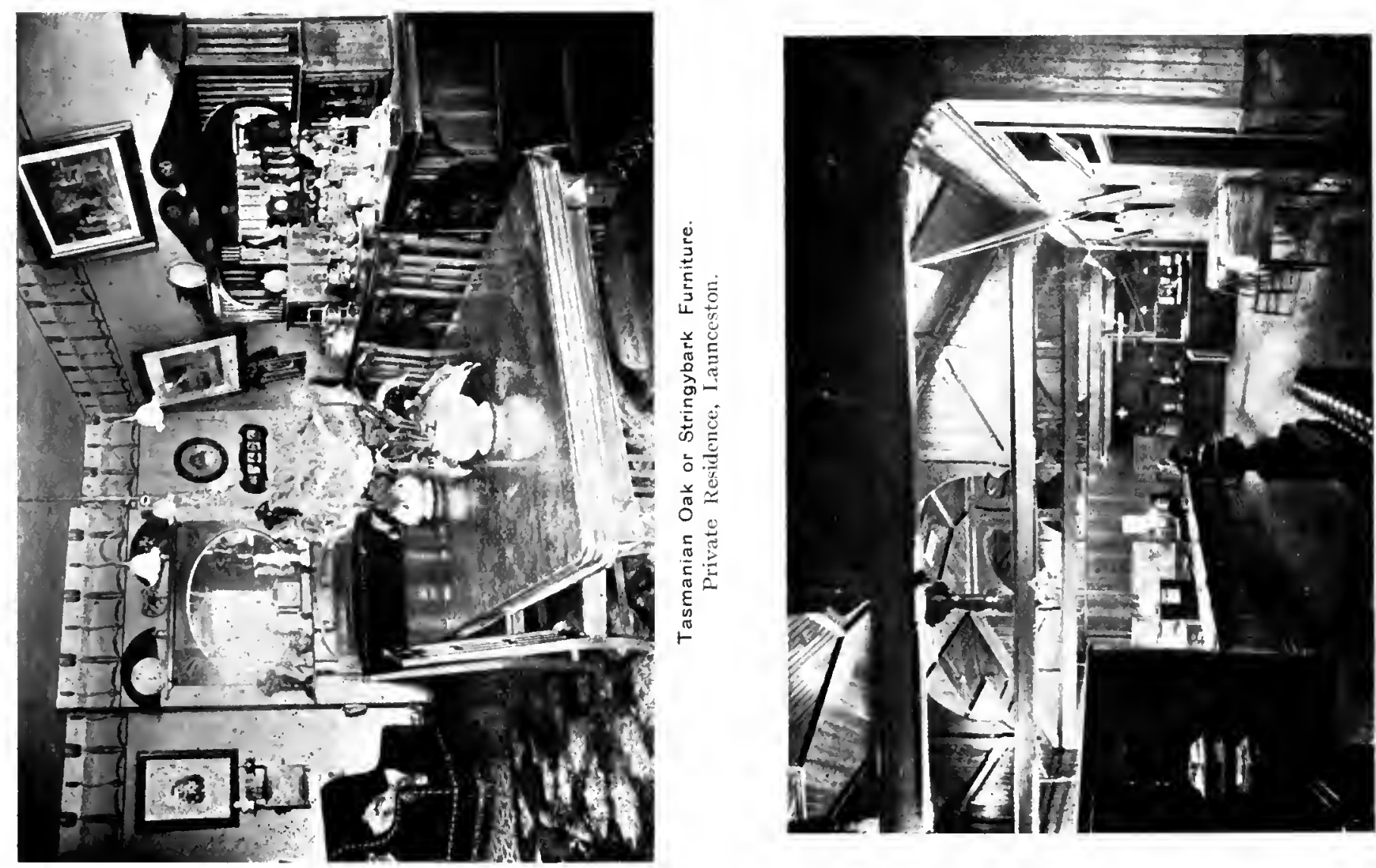

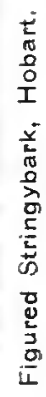



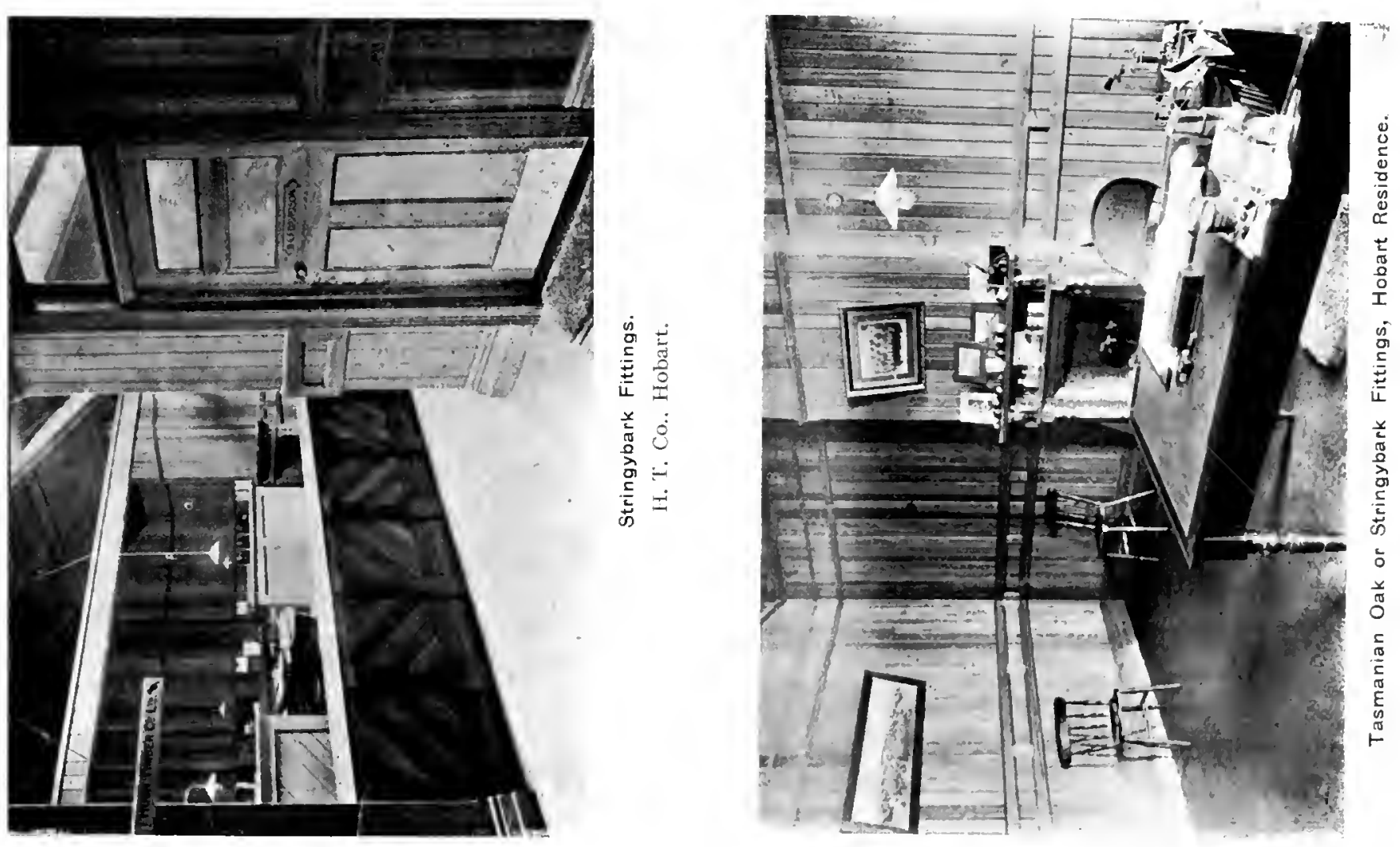

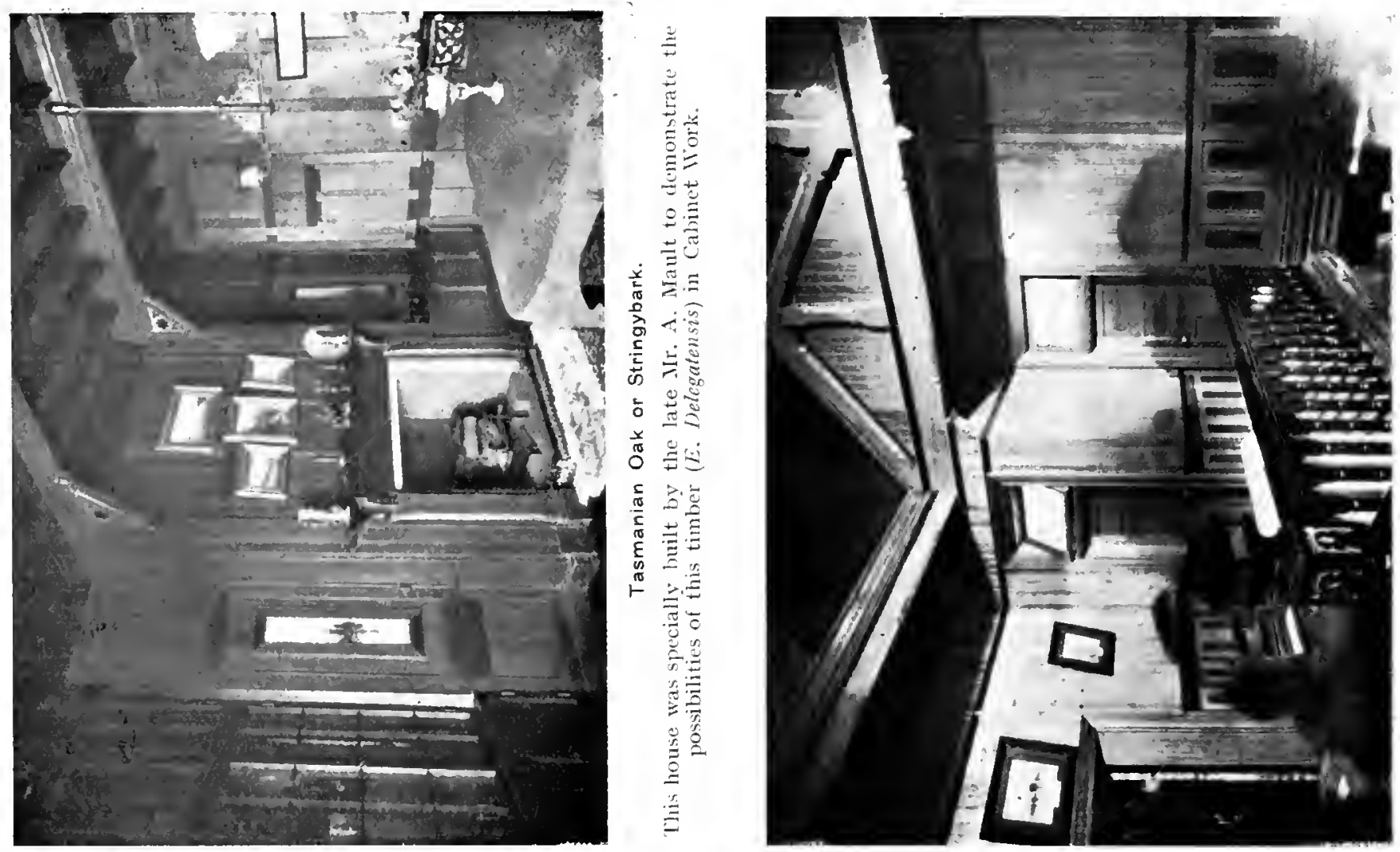


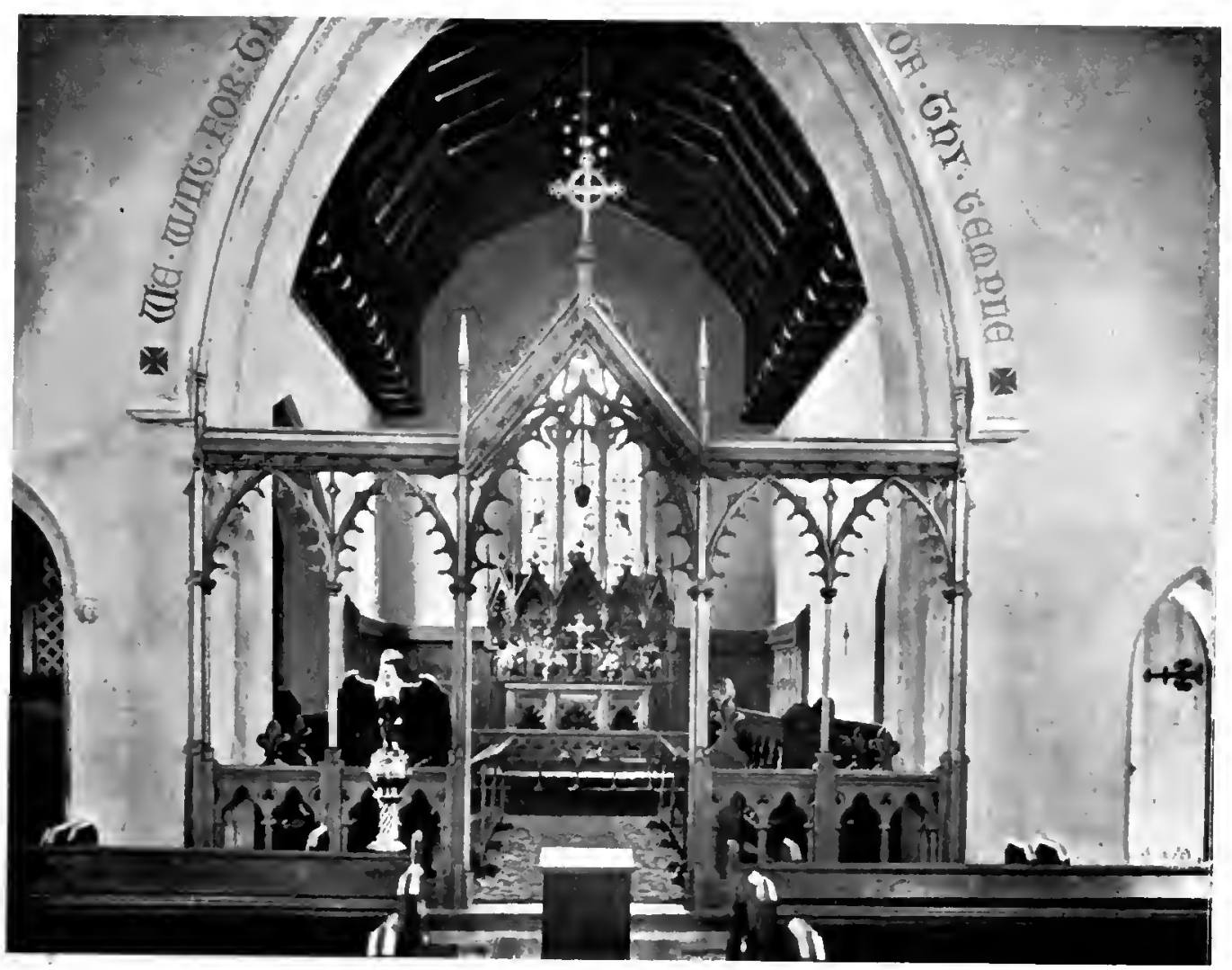

Tasmanian Oak or Stringybark Carved Screen.

All Saints' Church, Hoburt. 

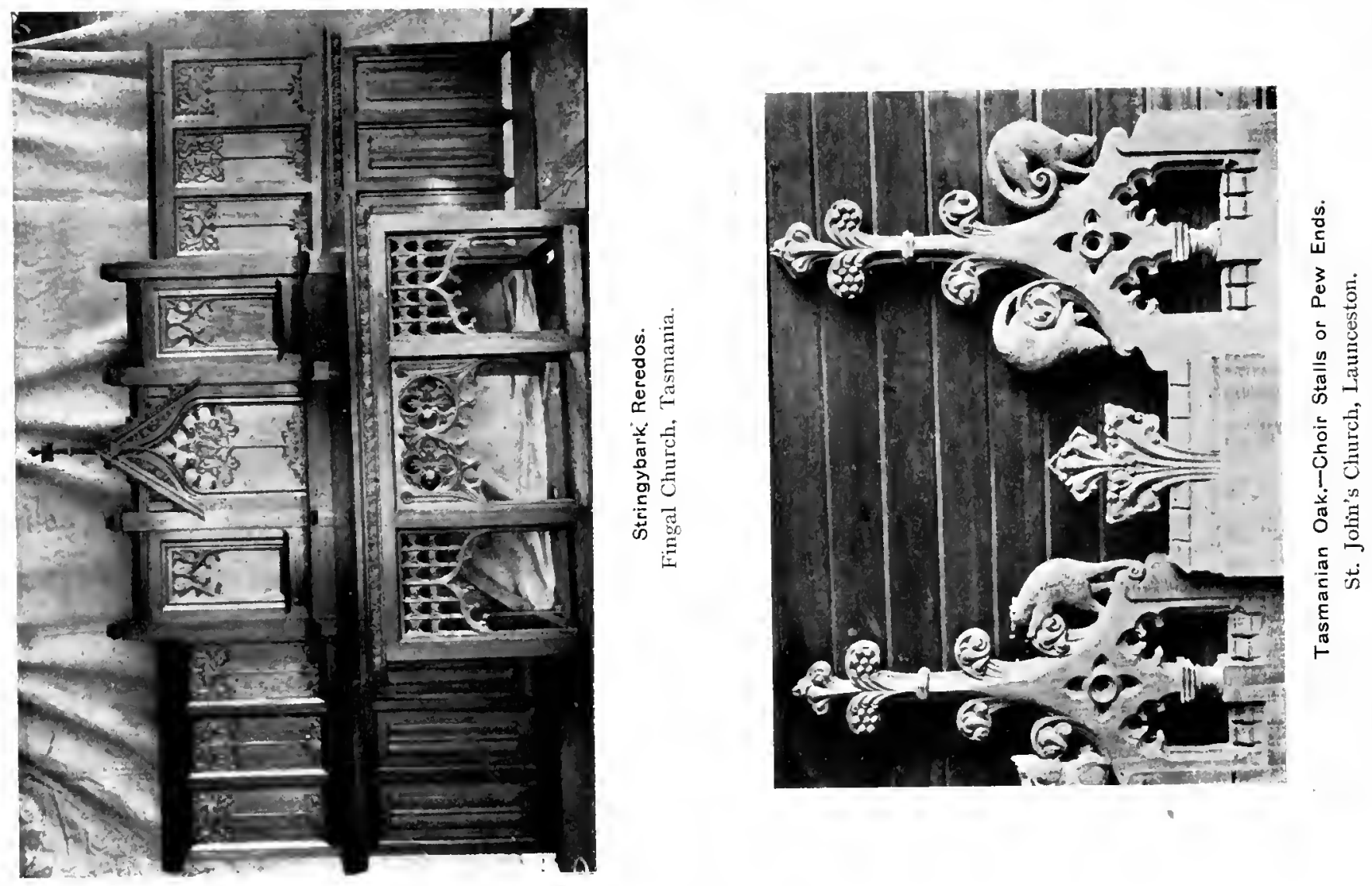

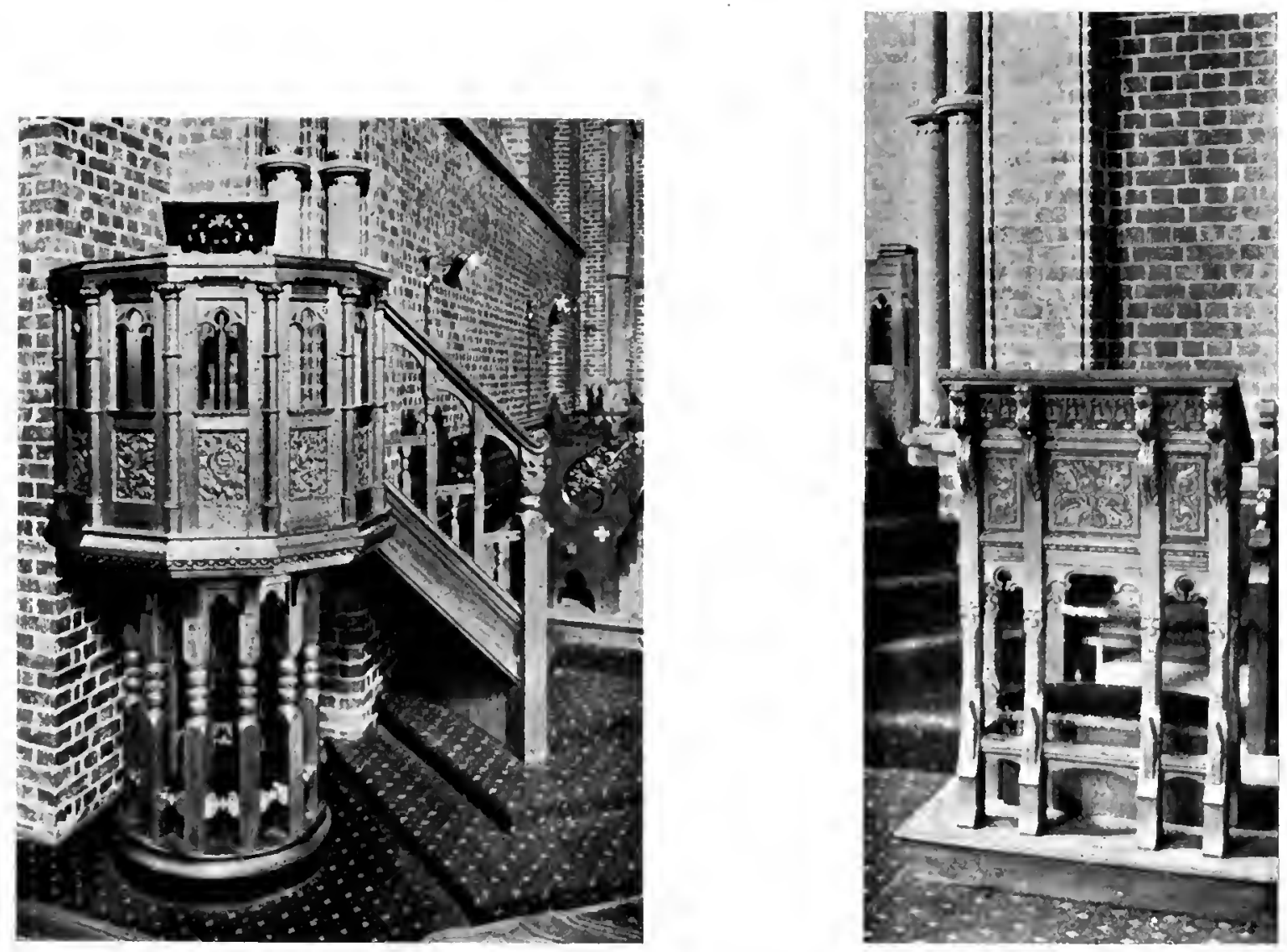

Tasmanian Oak or Stringybark Pulpit and Reading Desk.

Trinity Churcl, Launceston. 


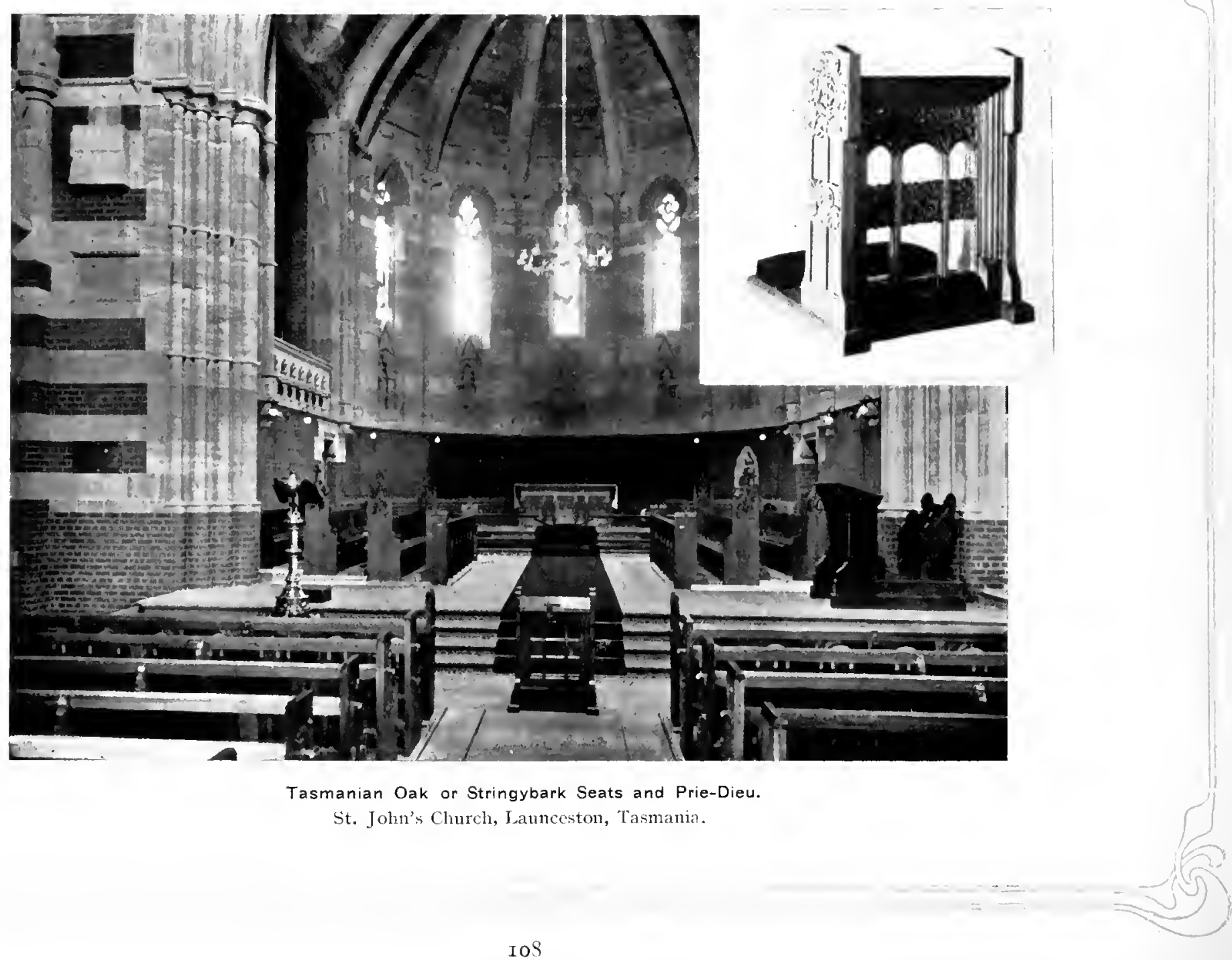




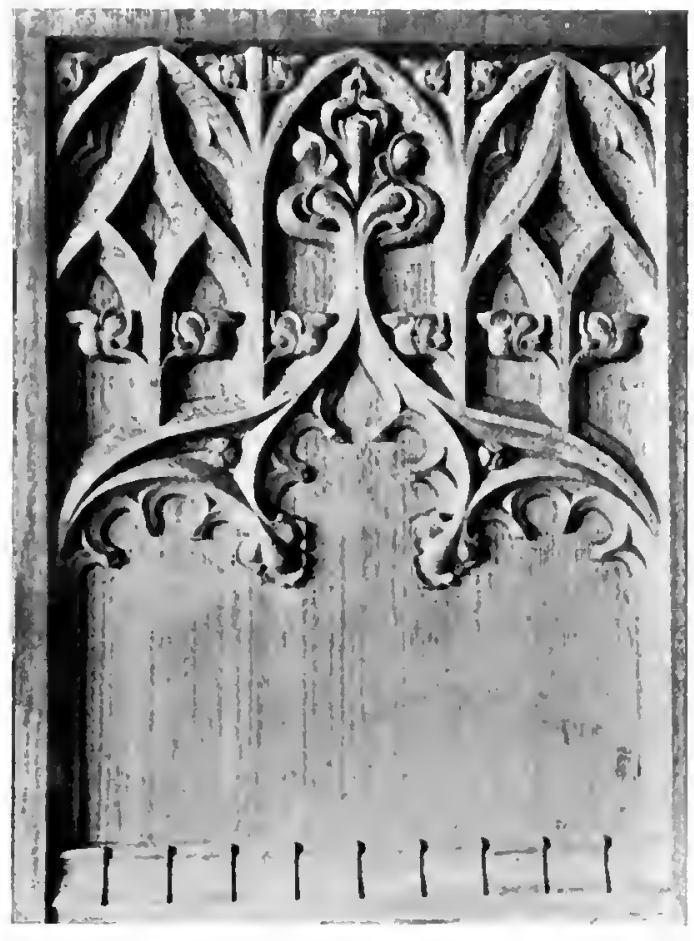

Tasmanian Oak Carved Altar Panel.

St. John's Church, Launceston.

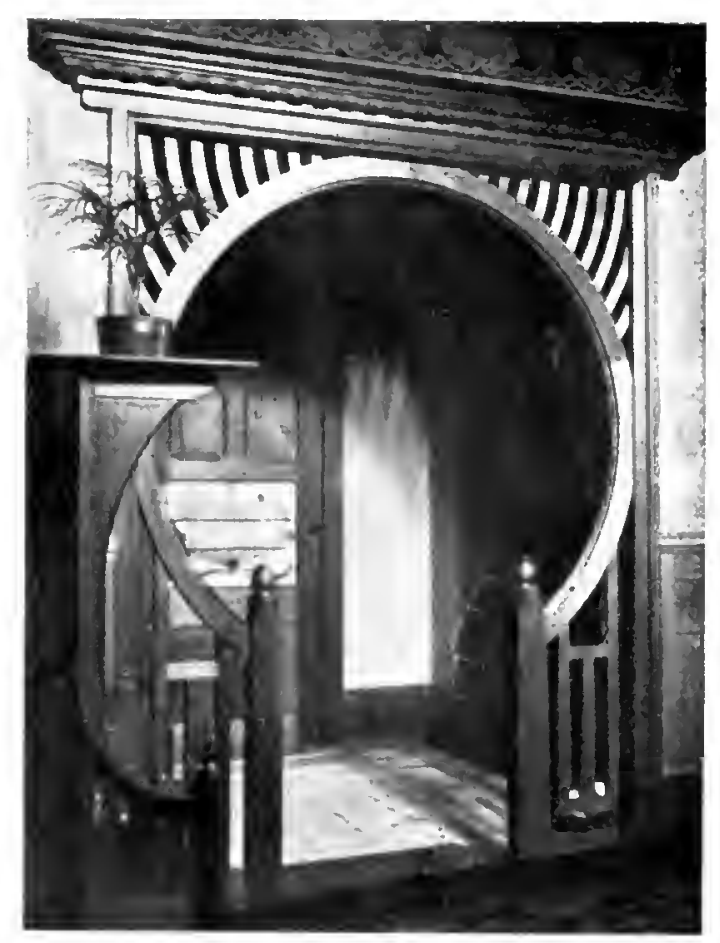

Hall Grille of Tasmanian Oak.

C. B. Bracly's Residence, Iaunceston. 


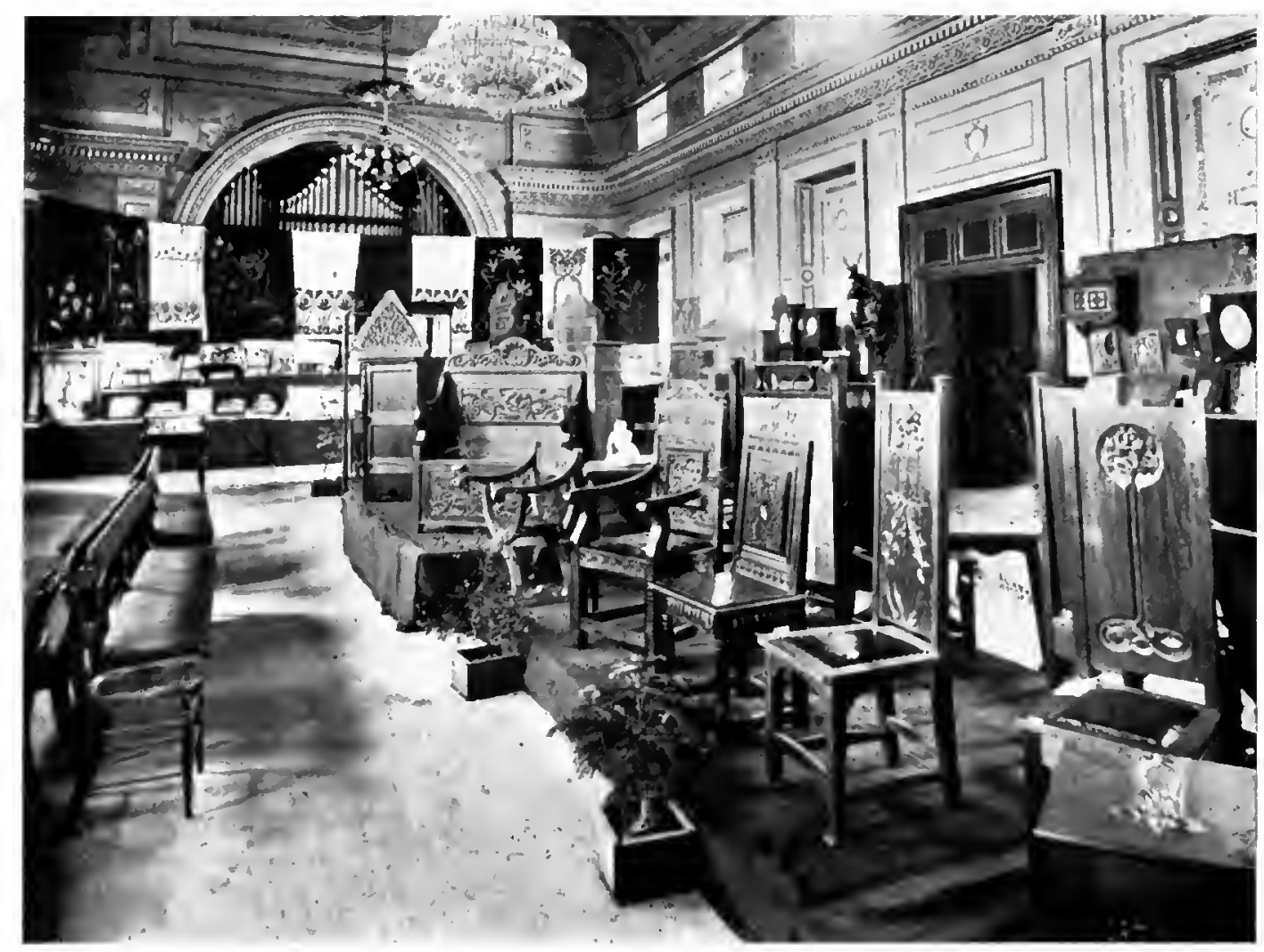

Specimens of Carved Tasmanian Timbers. 


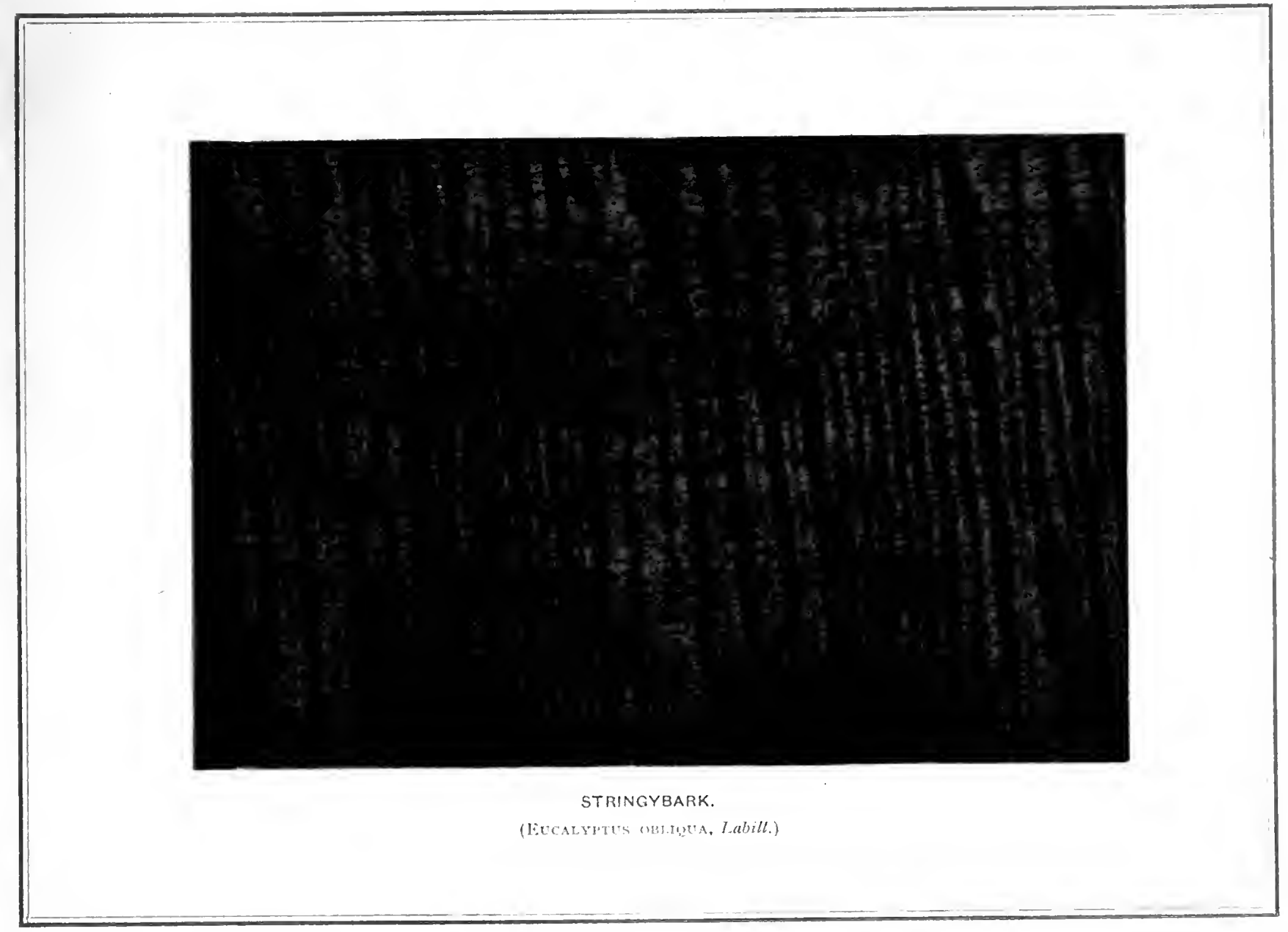


$4=$

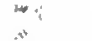

, 


\section{A Stringybark.}

\section{(Eucalyptus obliqua, L'Her.)}

This wood is not quite so straight-grained as that of E. Delegatensis, a circumstance that rather enhances its value than otherwise, as a cabinet timber.

It is light medium in weight, pale brown in colour, planes and dresses well, and is a good serviceable cabinet timber, but care must be taken to remove the sapwood, which is subject to the attack of borers. It is easily seasoned. In Tasmania, quantities of furniture are made from it, and it could be used for general interior fittings. Occasionally found with a ringed figure.

Deseription of the Tree. - It is one of our largest forest trees, with a stringybark right out to branchlets. Leaves lanceolate, oblique, varying in size up to 7 inches long and 2 or 3 inches wide. Venation distinct, lateral veins oblique, forming an acute angle with mid-rib. Buds numerous, in lateral peduncles, tapering into the peduncles, operculum domed. Fruits oval up to $\frac{1}{2}$ inch long and $\frac{1}{4}$ inch broad, rim countersunk.

Geographical Range.--On the Coast Range from Queensland to Victoria and all over Tasmania, except the highlands. 


\section{Red Mahogany.}

(Eucalyptus resinifera, Sm.)

Only rarely now is this timber found in cabinet work, and it requires careful selection before use, as it is subject to borers, which of course detracts considerably from its value. If obtained free of these it looks very well when worked up into various articles of cabinet work, especially if the choice rest with a red coloured timber. It is hard, heavy, close grained, darkred in colour, dresses well and takes a good polish, and is in many respects very similar to Jarrah, and could be used for the same purposes.

Description of the Tree.-A tall forest tree extending nearly throughout the whole range of the Coast district of New South Wales to Queensland. Leaves lanceolate, rather large and broad, thick, drying a light green colour on both sides; venation faint, the lateral veins almost transverse and parallel, the intramarginal vein close to the edge. Oil glands few. Umbels axillary: stalk compressed, number of flowers varying up to twelve in an umbel. Buds pedicellate: calyx hemispherical. Operculum conical (sometimes sereral lines long) or hemispherical and acuminate. Stamens all fertile; anthers attached to a comparatively large connective parallel, broad at the top. Fruit hemispherical, usually 3 lines in diameter, rim thick, capsulesunk, valves acutely acuminate, well exserted.

Geographical Range.--From Rockingham Bay, Queensland, to Port Jackson, New South Wales. 


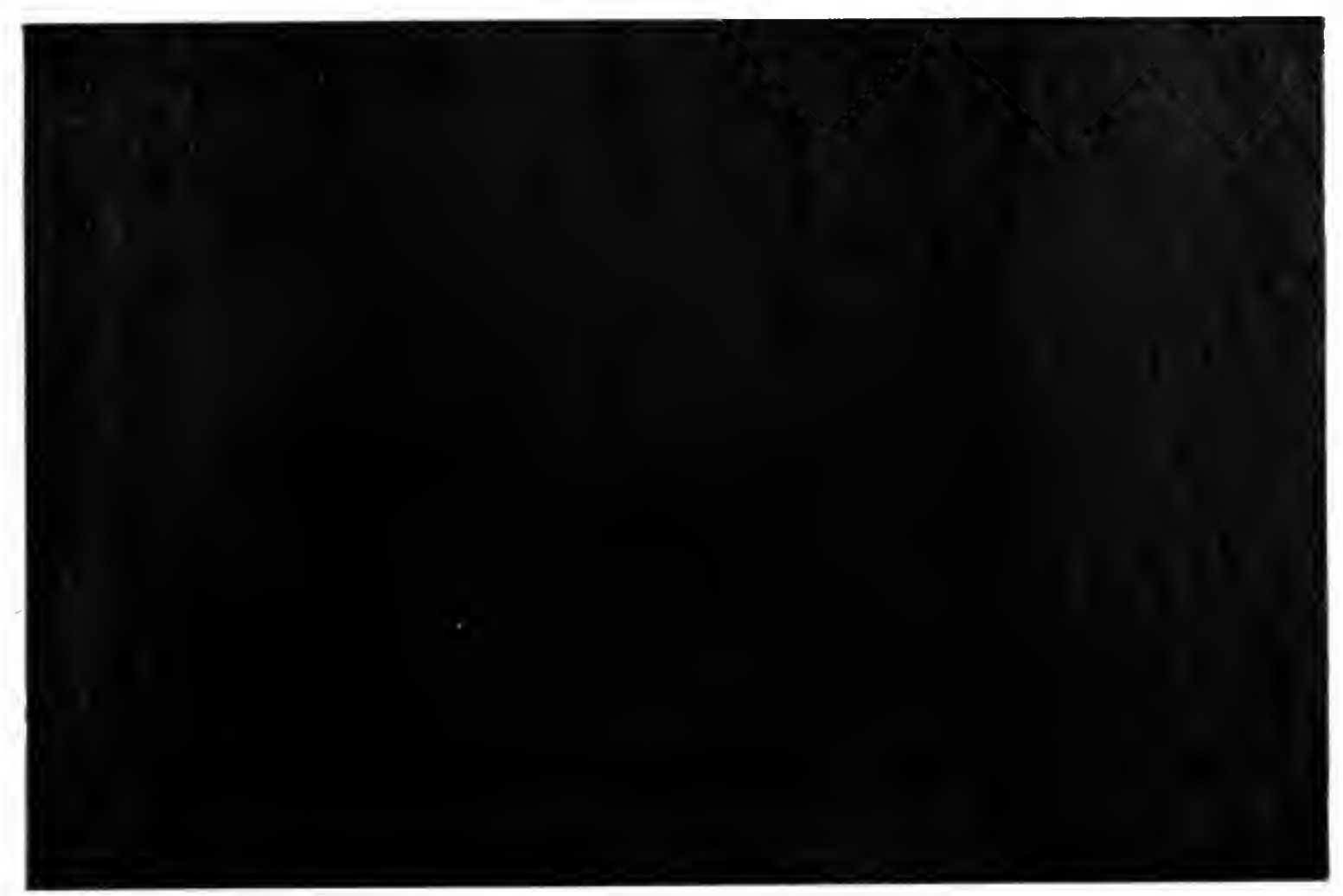




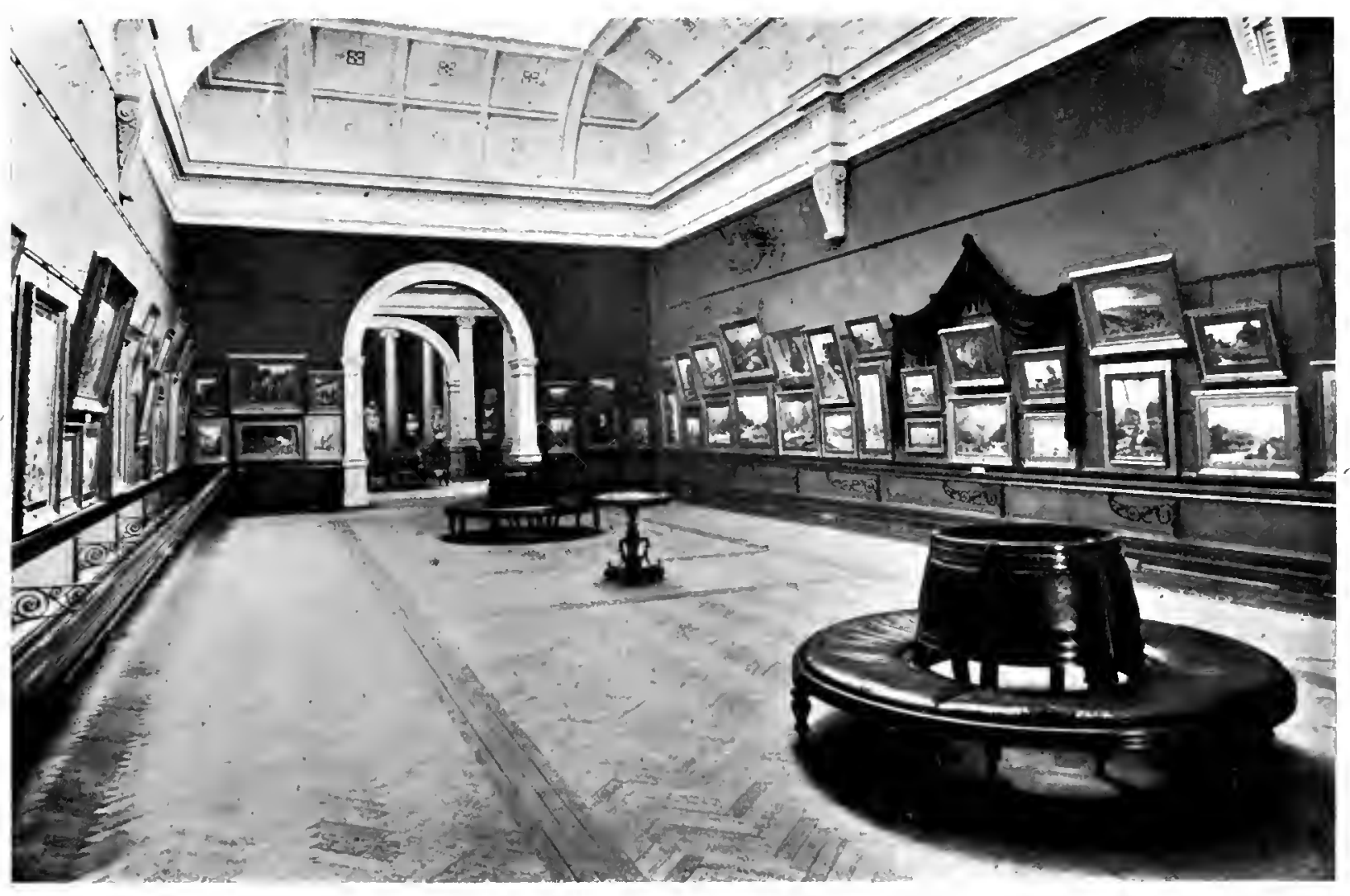

Red Mahogany and Silky Oak Parquetry Floor.

National Art Gallery, Sydney. 


\section{Jarrah. \\ (Eucalyptus marginata, Sm.)}

One might at first think that this Eucalyptus could hardly be classed as a cabinet timber, yet some excellent specimens of the tradesman's art made from it are to be seen in Australia, and this species is particularly suitable for this technical application. A very fine Jarrah suite of furniture is on view at the Imperial Institute in London. It is certainly heavy, but not more so than English Oak. The colour is a rich red, and this is one of, if not its greatest recommendation in this direction. For office fittings it looks particularly rich, and is preferred by many to Mahogany or Cedar. It is very suitable for billiard tables, wainscotting, baluster rails, railway carriage decoration, dining-room or library furniture, or for shop and office fittings, being now extensively used for these purposes.

Description of the Tree.- One of the finest forest trees of Vestern Australia, sometimes attaining a height of $\mathrm{I}_{5} \mathrm{O}$ feet, with a persistent and fibrous bark, and could be classed as a "Stringybark." Normal leaves lanceolate, curved, not long but variable, lateral veins oblique, spreading, very distinctly marked as well as the reticulations, coriaceous, pale on the underside, intramarginal vein removed from the edge. Flowers in axillary umbels or forming small terminal panicles. Calyx top shaped, surmounted by a conical operculum, the whole about $I$ inch long. Fruit about $\frac{3}{4}$ inch long, ove: $\frac{1}{2}$ inch in diameter, ovate, globular, rim truncate or contracted, valves not exserted.

Geographical Range.-Western Australia. 
$\backslash \backslash \times 11$

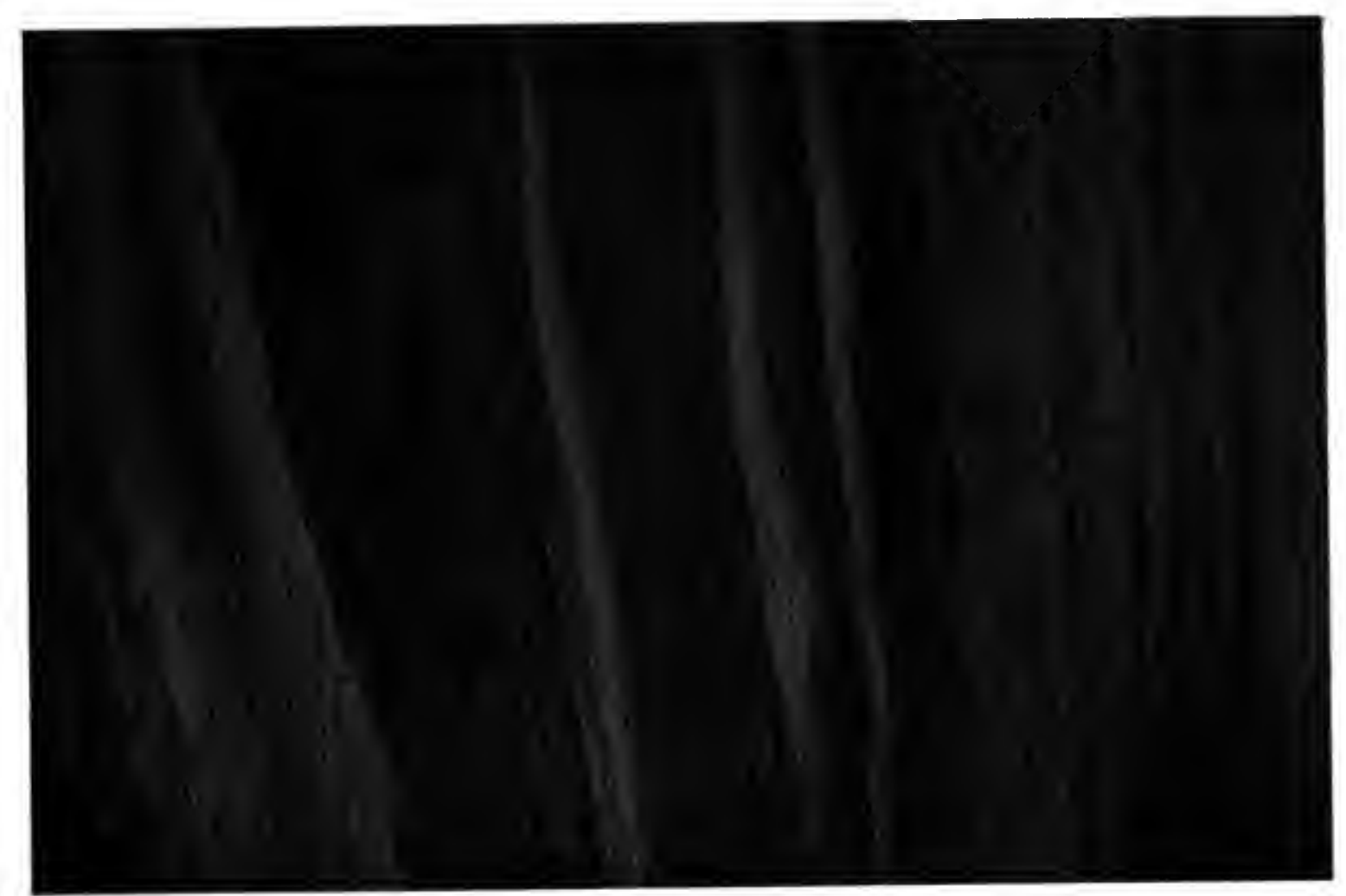




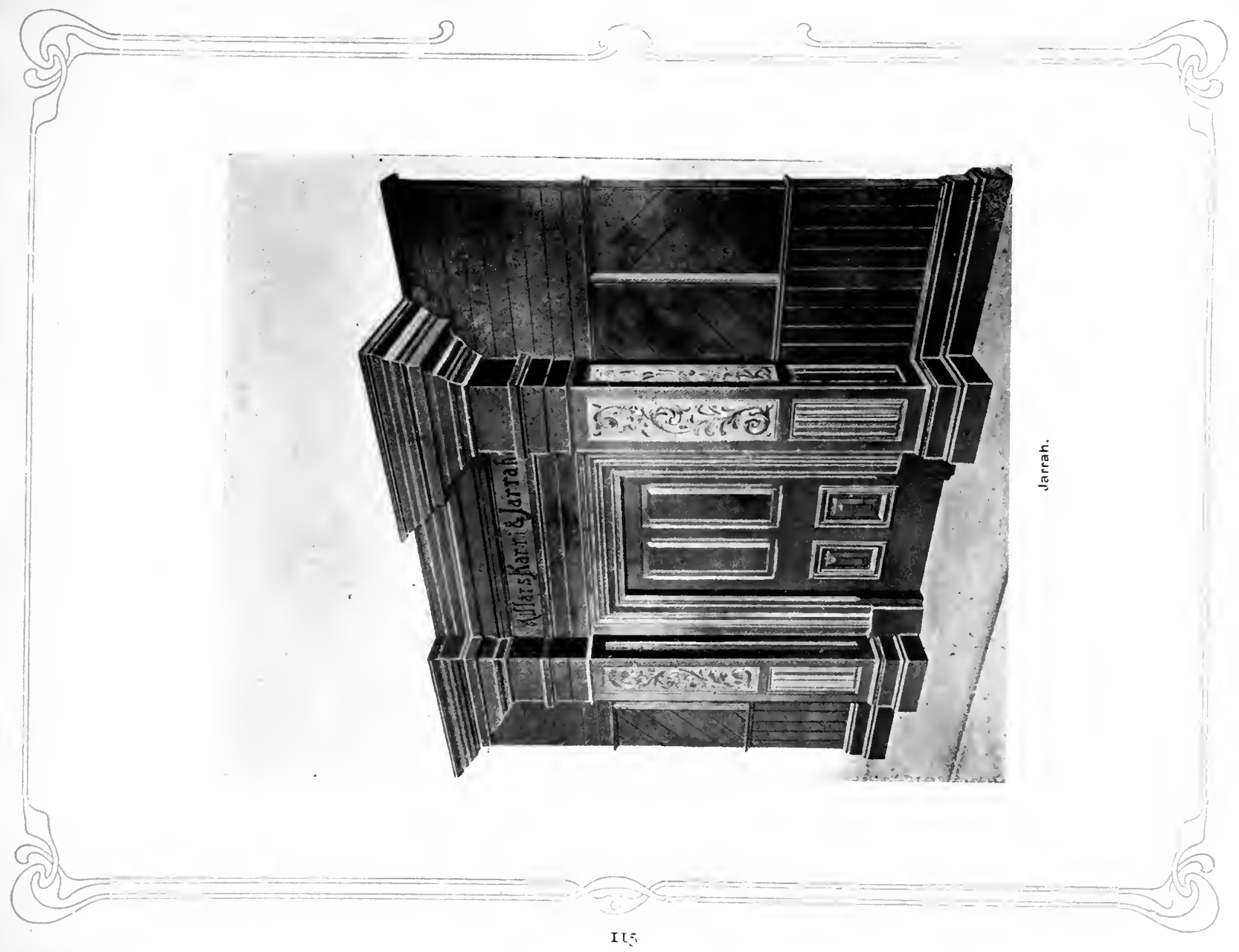




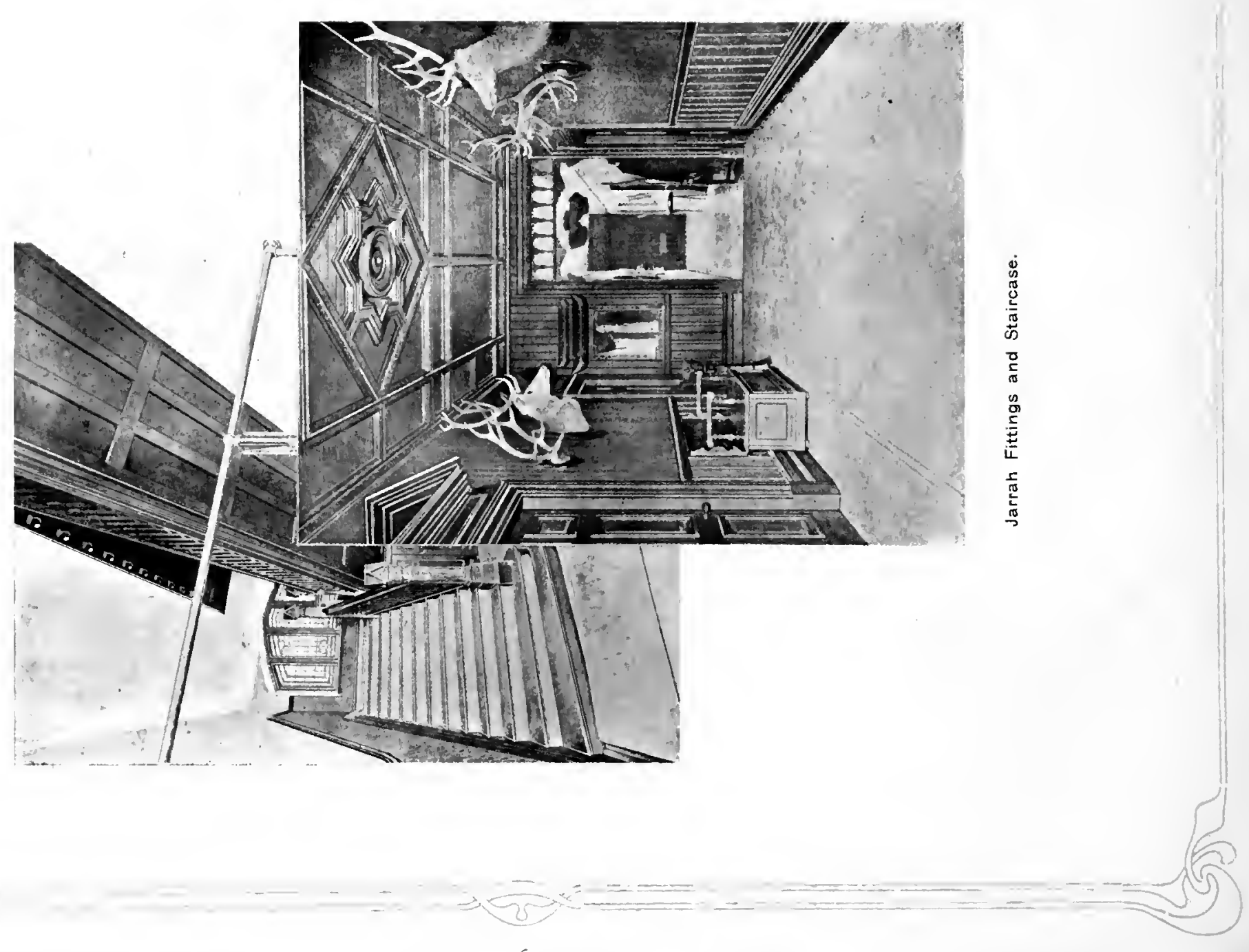




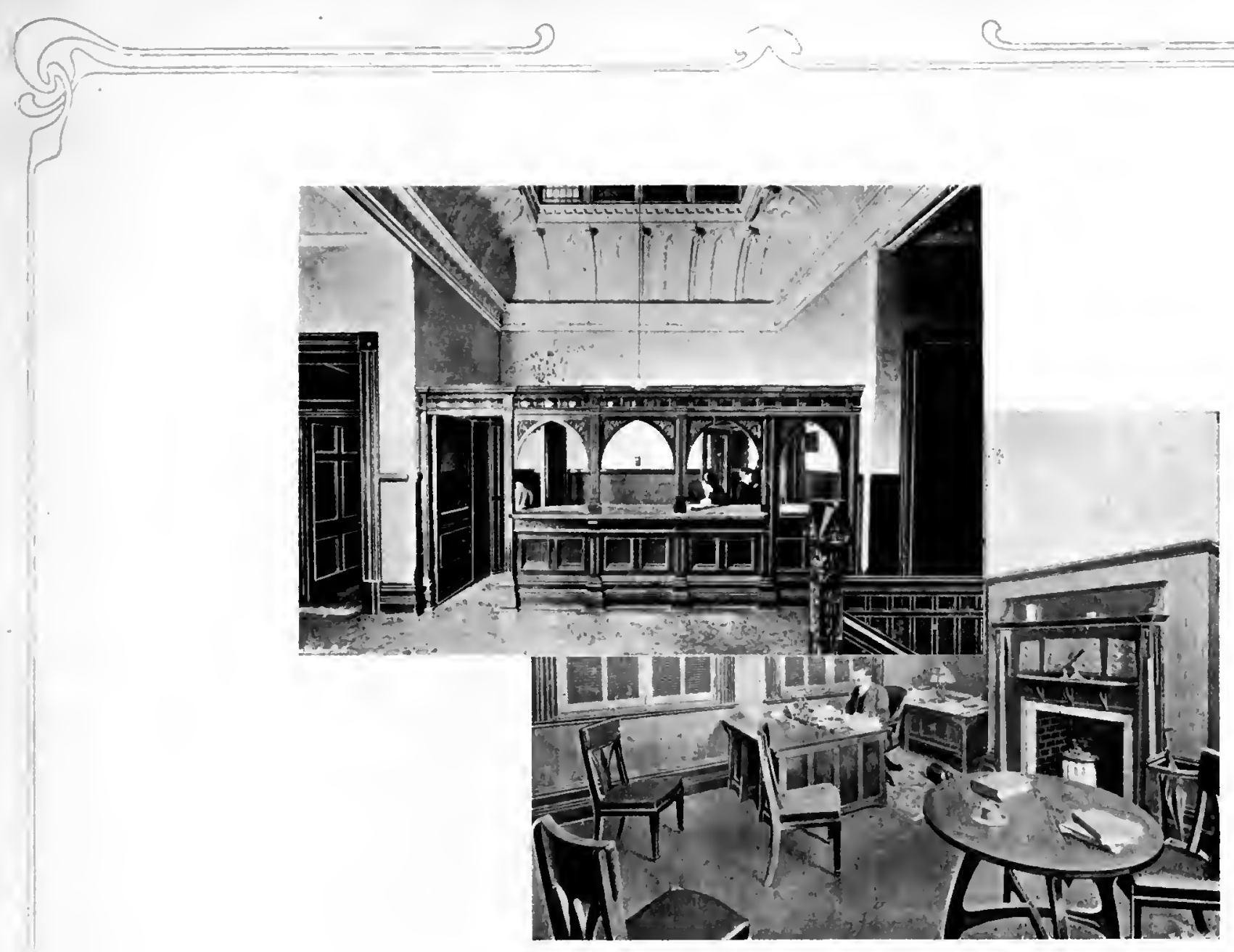

Jarrah Fittings and Furniture. 

XXX1

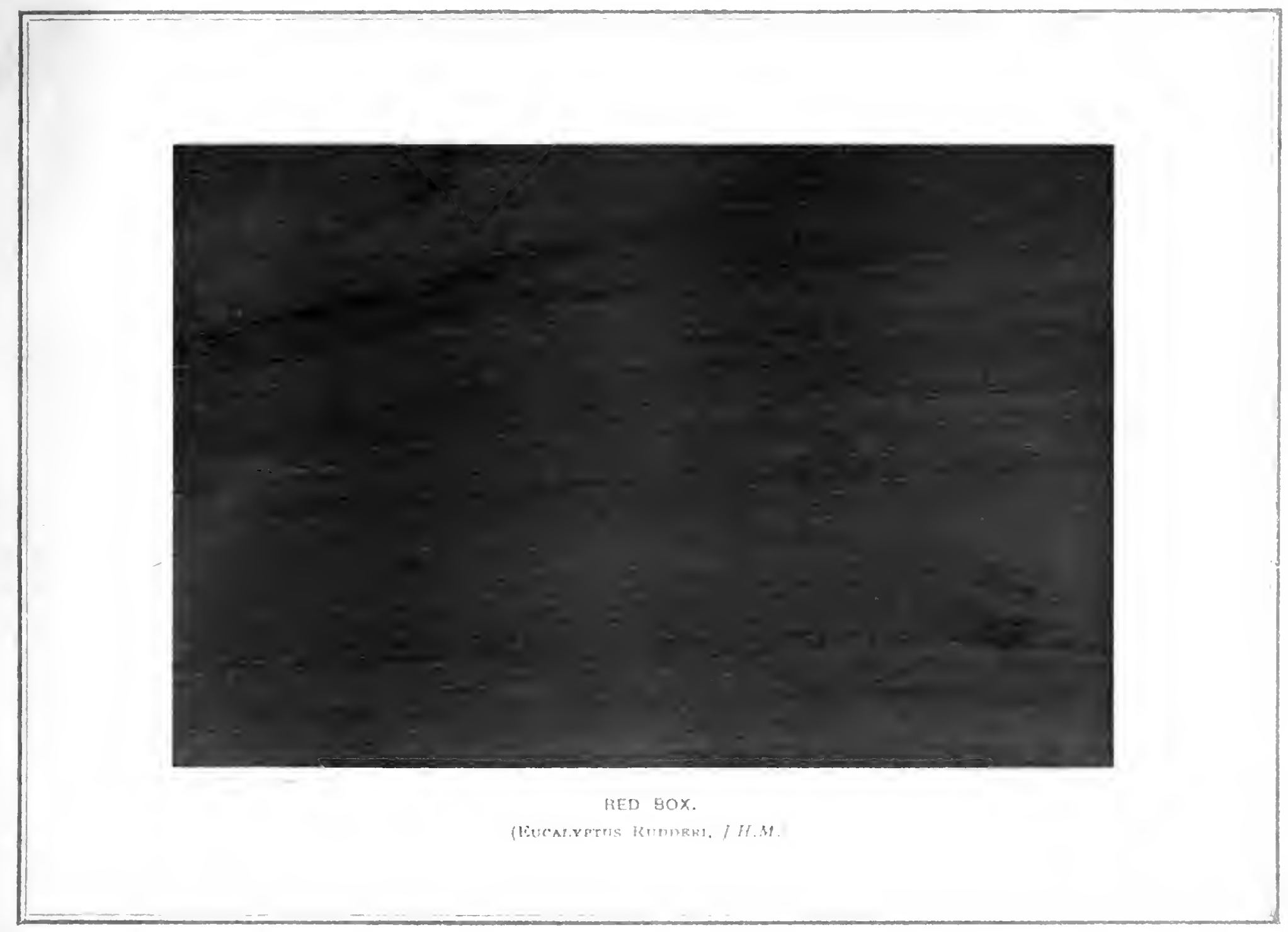




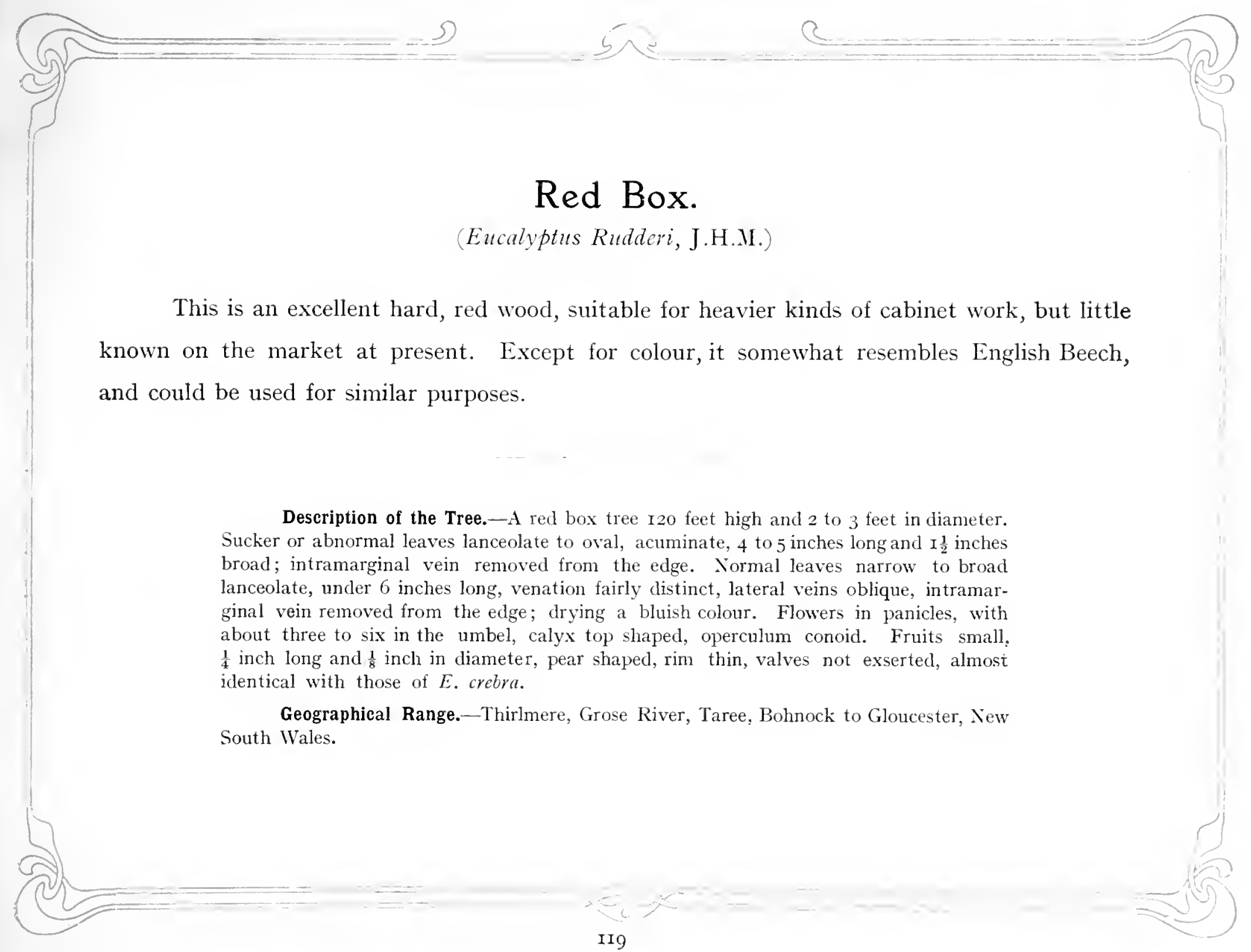




\section{Spotted Gum.}

\section{(Eucalyptus maculata, Hook.)}

Exception might be taken by some to the inclusion of this species as a cabinet timber; in fact, it was not till this work was about to go to print that specimens of its adaptation in this respect were produced. The waving of the grain is a distinct advantage in this connection, and materially assists in the decorative side of the furniture recently made locally and exhibited in Sydney. The colour somewliat resembles that of English Oak, and it is probably just as hard and of the same texture to work. It is open in the grain and is not recommended to be polished, as, like Oak, it shows to better effect in the unpolished or waxed condition. A press of this timber was exhibited in the window of a Sydney firm lately, and looked really handsome, although it was from a Eucalypt. This piece of furniture is now at the Commonwealth Offices in Melbourne. For chairs, couches, \&c., where strength is required, and the size of the timber to be used has to be limited, it ought to give every satisfaction.

Description of the Tree.-An average forest tree amongst Eucalypts; with a smooth, dull, lead-coloured bark. The sucker or abnormal leaves large, sometimes a foot long, and 3 inches broad, lanceolate, venation oblique, well marked, intramarginal vein close to edge. The normal leaves ovate-lanceolate or lanceolate, 4 to 6 inches long, lateral veins oblique and distant, the intramarginal one removed from the edge. The flowers occur in a corymb or panicle formed by three-flowered umbels with several together in short leafless branches. Buds shortly cylindrical, operculum hemispherical, or sometimes conical. The fruit ovoid-urceolate, usually about $\frac{1}{2}$ inch long and $\frac{1}{4}$ inch broad; rim narrow; capsule sunk.

Geographical Range.-From Brisbane River, Queensland, to southern Coast districts of New South Wales. 


$$
\text { , }
$$

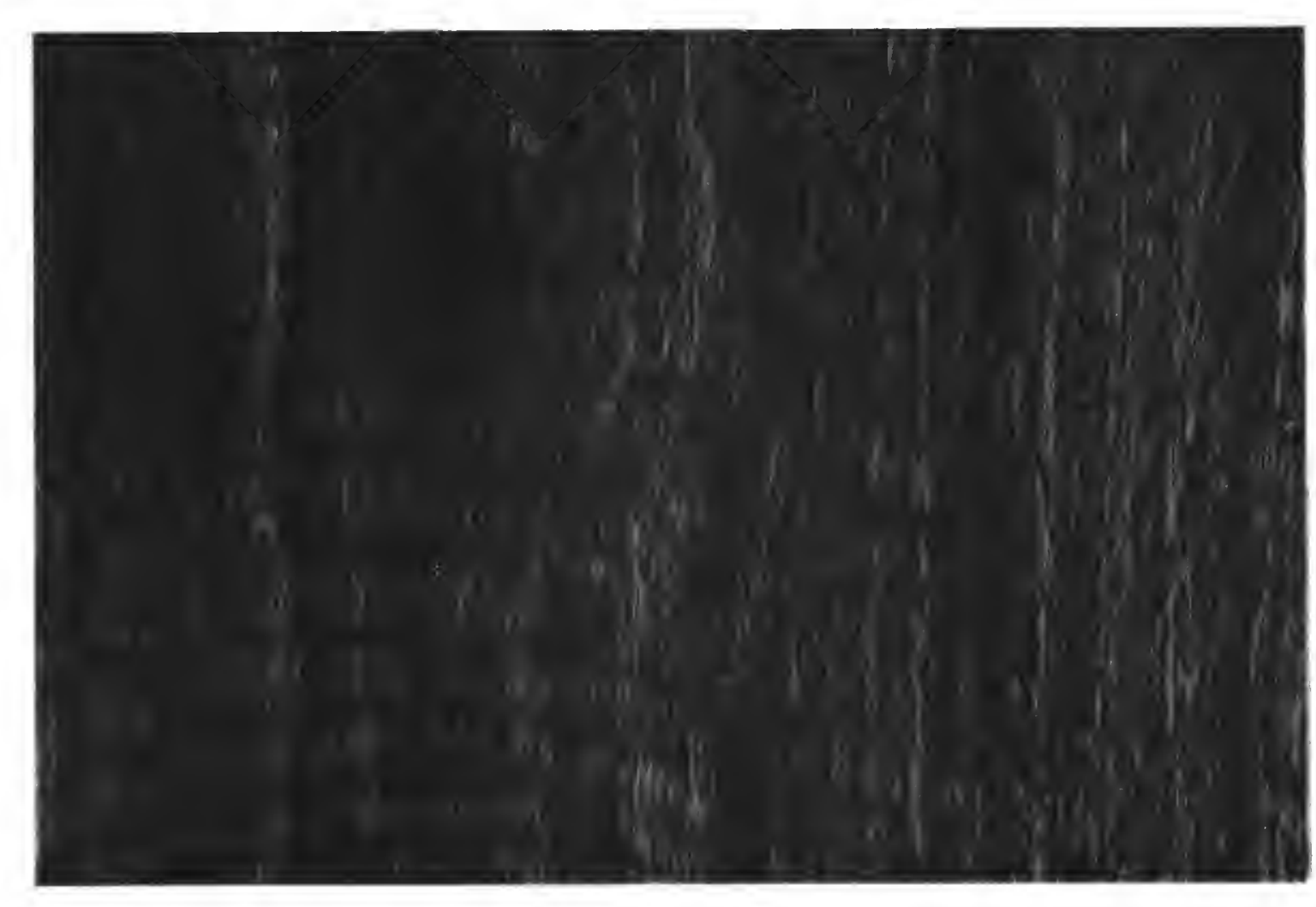

SPOTTED GUM.

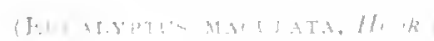




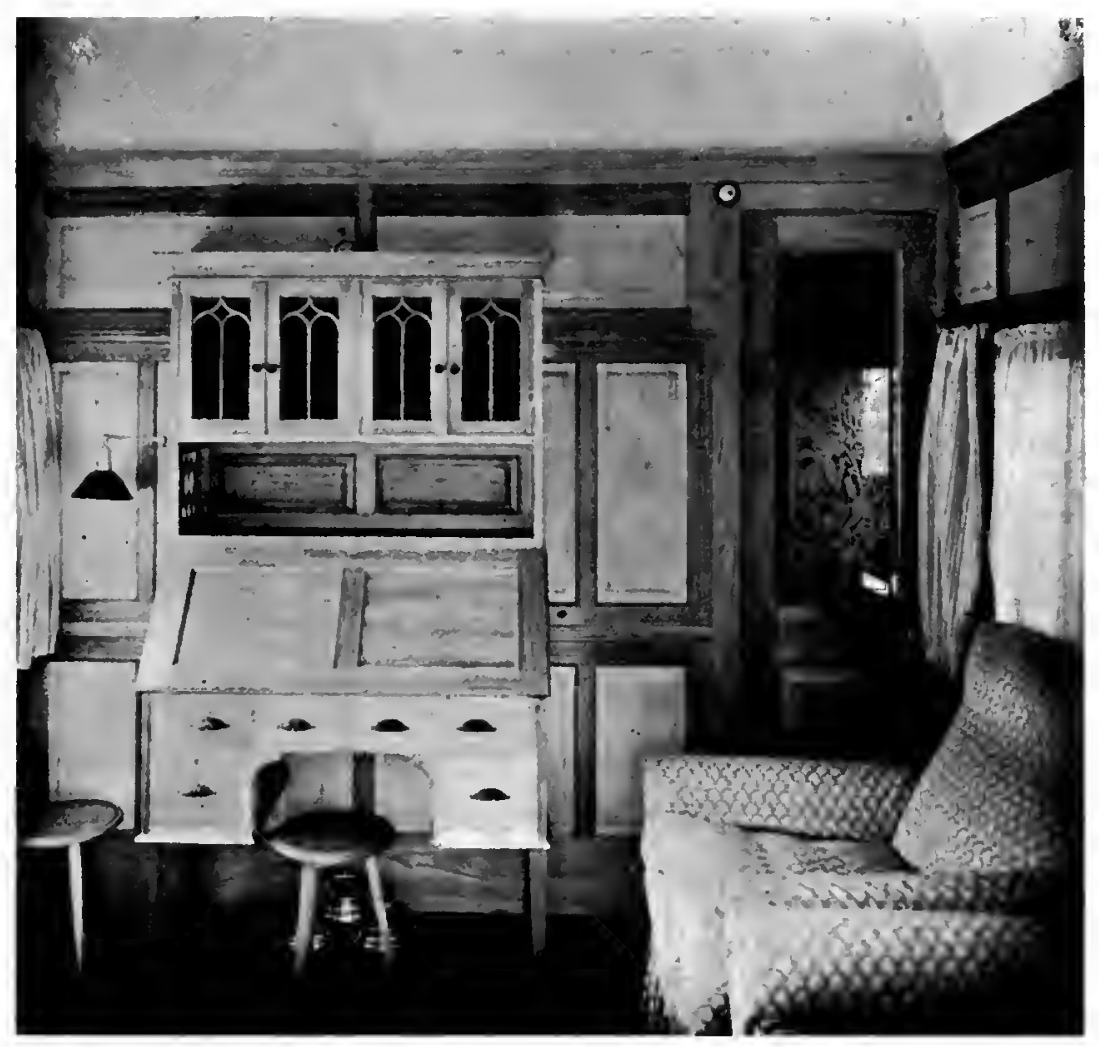

Spotted Gum Framing, Celery Top Pine Panels.

Smoking.room, State Governor's Carriage, N.S.W. Governnent Railways. 


\section{Sydney Blue Gum.}

(Eucalyptus saligna, Sm.)

The inclusion of this species amongst our cabinet timbers might also be challenged by some, as it is rarely so used, but that does not lessen its claims to rank as one, for it possesses a rich, pleasing, red colour, and looks handsome when polished. It is perhaps a shade lighter than Jarrah, and more open in the grain, but it is specifically one of the lightest of the Eucalyptus timbers, much more so than Forest Red Gum, Murray Red Gum, \&c. Its introduction in cabinet work is yet a desideratum, but juclging from polished specimens in this Museum it should rank as a first-class one for this purpose. Perhaps its non-use is due to fashion, as this is not the age of red timbers, for the king of all such-the Cedar-is discarded in this day of changing tastes; but fickle fashion will come again to its own, and may then turn to some of our red timbers. Sydney Blue Gum is a rapid grower, with an even, open-grained texture; planes, polishes, and turns well. The fact of its being used so extensively in coachbuilding is sufficient evidence of its strength, durability, and reliability, and for the heavier classes of furniture it ought to give every satisfaction.

Description of the Tree.-A tall tree, growing to its greatest height and perfection in the gullies of the coast and mountains. Bark, either smooth, blith-white with a silvery sheen, or rough at the base, similar to that of E. robusta. "Sucker" leares alternate, lanceolate. IIature leaves lanceolate, occasionally falcate, drying a bluish green, pale on the underside, intramarginal rein close to the edge; transverse veins numerous, fine and parallel, slightly ohlique. Feduncles axillary, with a few, mostly five to seven, flowers, either on a slender pedicel or almost sessile. Calyx turbinate or conical. Operculum hemispherical, shortly acuminate. Ovary flat-topped. Fruit hemispherical, about 3 lines in diameter, rim thin, valves rery slender and well exserted. Wales.

Geographical Range.-Southern parts of Queensland to Port Jackson, New South 


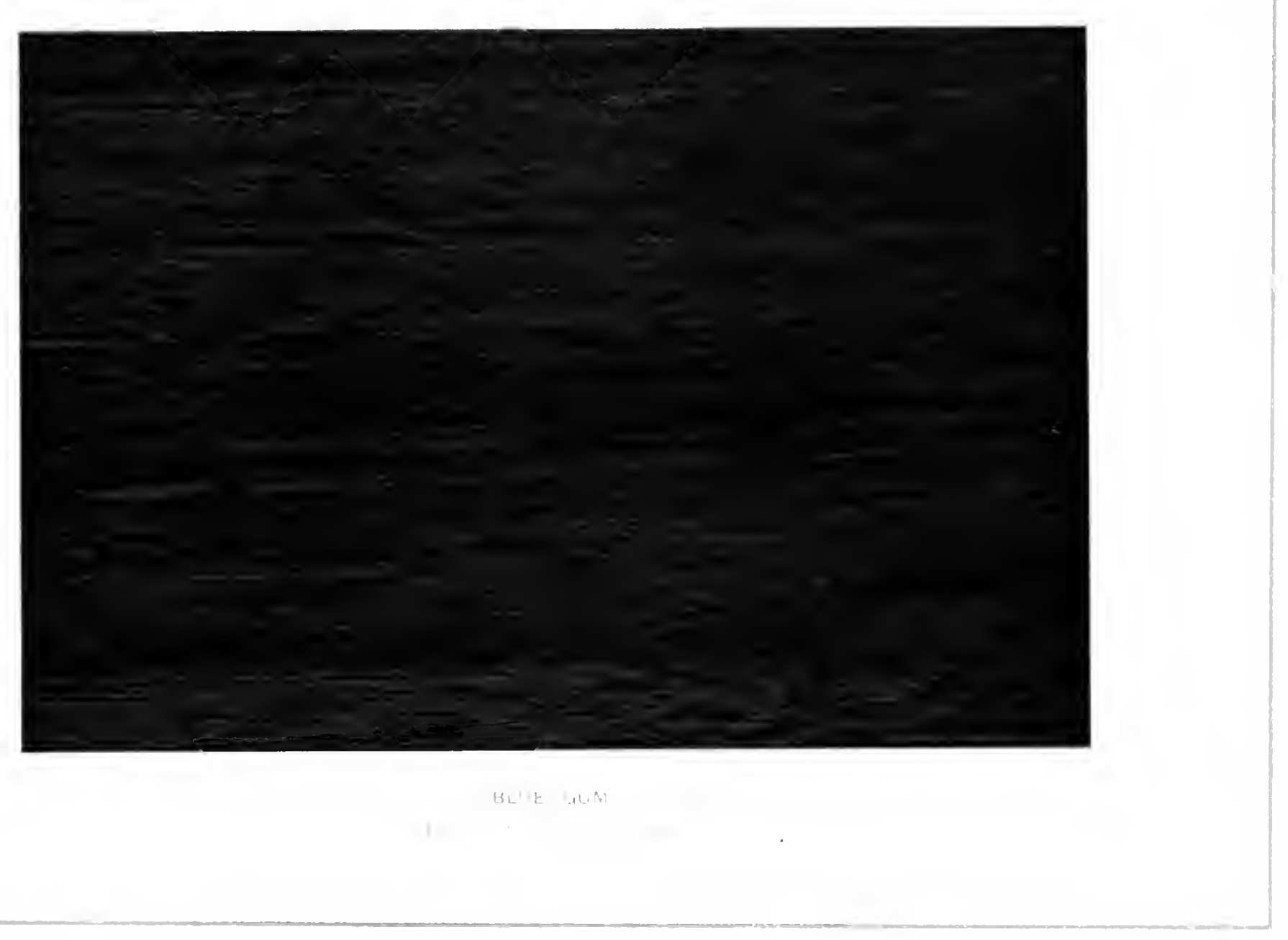




\title{
Slaty Gum.
}

\author{
(Eucalyptus Dawsoni, R.T.B.)
}

Slaty Gum has a rather comparatively restricted distribution, but, nevertheless, amongst red timbers it is one of the finest, for it is hard, heavy, close-grained, and polishes well. It could be turned to splendid use where strength, weight, and durability are required, such as billiard tables, newel posts, handrails, railway carriage parts, \&c. At present it is quite unknown on the Sydney market.

Description of the Tree.-One of the finest upstanding trees of the Australian bush, having a clean white or slaty coloured bark. It is characterised by its long, clean barrel, absence of lateral branches, and glaucous foliage and branchlets. The leaves are glaucous in both forms, but the "sucker" of the younger trees are oval, 2 to 5 inches long, or oval lanceolate 5 inches long, and petiolate; renation well marked, oblique. The normal leaves are lanceolate or narrow lanceolate, but rather small for so tall a tree generally; measuring up to 5 inches long. The venation is not too distinct, lateral veins oblique, no intramarginal vein. Flovers mostly in terminal panicles, or axillary racemes at the end of the branchlets.

Geographical Range.-Murumbo, Goulburn River, and to the north-west and ranges surrounding the Liverpool Plains. 


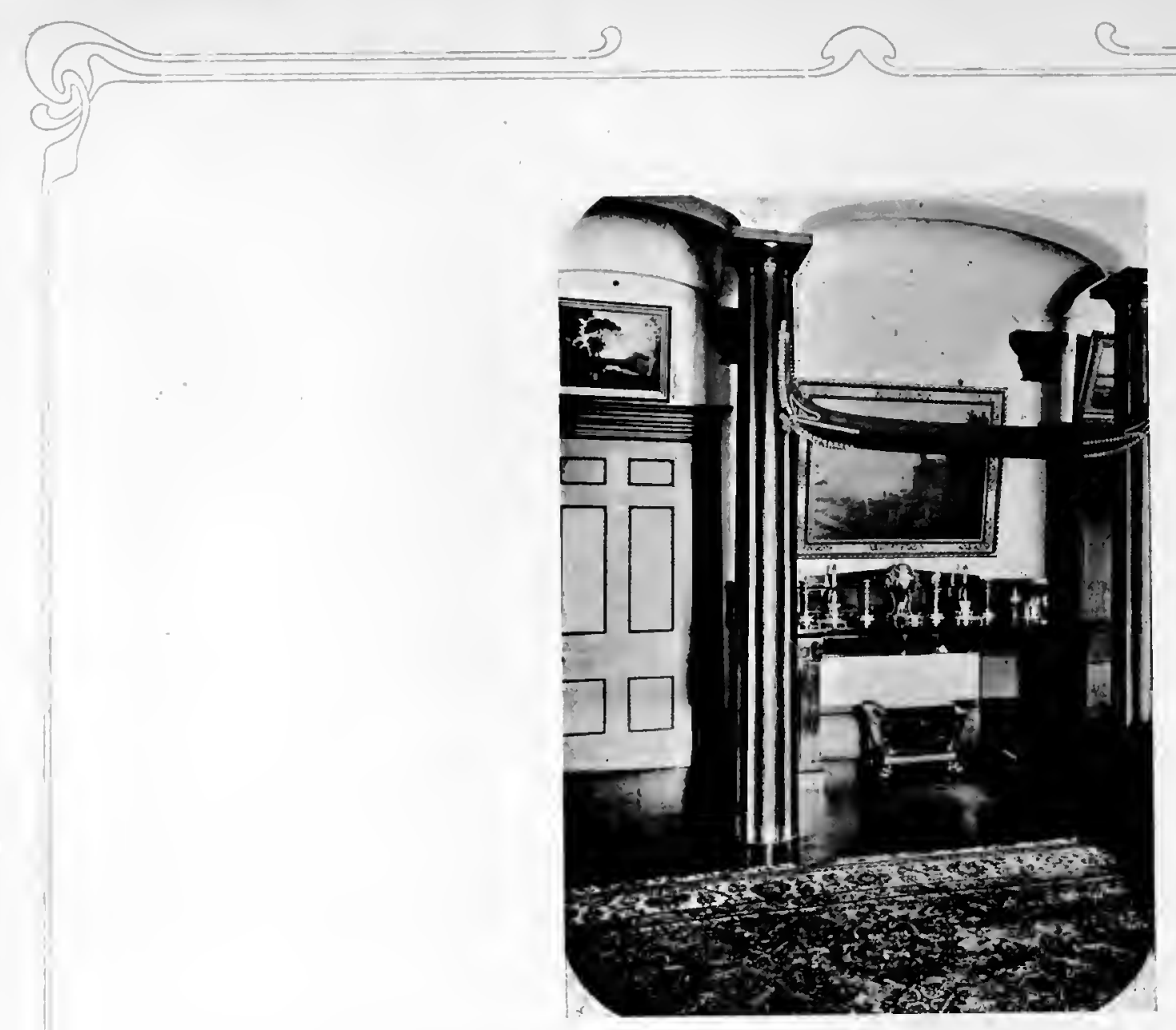

Fluted Ironbark Columns.

Camden House, N.S.W. 
NATURAL ORDER.

\section{COMPOSIT Æ.

In this class of the botanical kingdom one has the most widely distributed plants in the whole world, species being found at all altitudes and in all climes. Only rarely do they attain tree size, and, of course, Australia possesses this exception in an Olearia (Aster), viz. :-Olearia argophylla, the Musk of the Coast district. This Compositæ attains tree size, and produces an attractive timber of a fawn colour, and a very ornamental root stock. The odour from which it takes its common name is found in the leaves, but so far has not yet been isolated.

\section{Species Illustrated in Colour:-}

Musk (Olearia argophylla, F.v.M.). 


\section{Musk.}

(Olearia argophylla, F.v.M.)

This tree is a giant amongst its class, as it is quite unusual for a Compositæ to attain arboreal proportions, but still at the same time another Compositæ, the Cotton Tree or Dogwood (Senecio Bedfordii), exceeds it in height. It is recorded as having a height of 25 feet, and a diameter of 12 inches. The timber is straight-grained, not hard, of a light chocolate colour, easily dressed, takes a good polish, and should not be kept in the log, but cut into planks as soon as felled; the sapwood, as well as the bark, being removed before stacked for seasoning. The root stock is large and spreading, and sometimes two or more stems grow from it. It is beautifully figured, not unlike American Bird's Eye Naple, and so is a valuable decorative wood for veneers, being quite unique in character. The range of its usefulness would, perhaps, be limited by the quantity available. It would be very useful for many ornamental articles, especially to be used in contrast with some of the lighter coloured timbers.

Description of the Tree.-Often a fair-sized tree with a stout stem, found in the brush lands of the Coastal districts. Bark light coloured, coming off in strips. Leaves alternate, petiolate, from oval-elliptical to oblong-lanceolate, acute at both ends, more or less callous denticulate, or rarely quite entire, 3 to 5 inches long, reticulate and glabrous above, silvery silky underneath. Flowers small, numerous in large terminal corymbs. Involucre oblong-turbinate; ray florets about three to five; disk florets, six to eight.

Geographical Range.- This tree covers a rather restricted area in the brushes of the South Coast districts. 


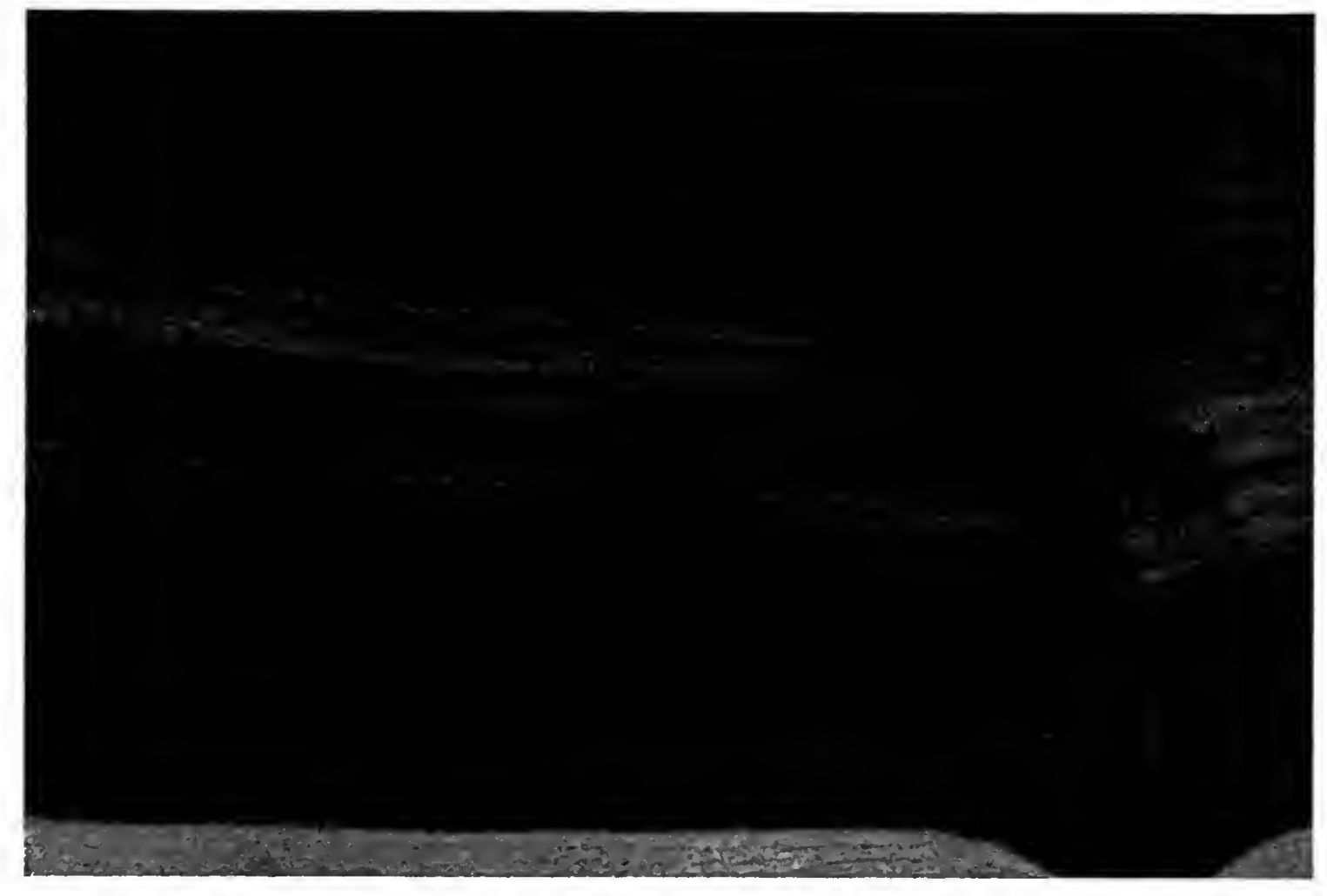

MUSK (Plain

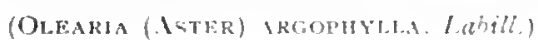


XXXX.

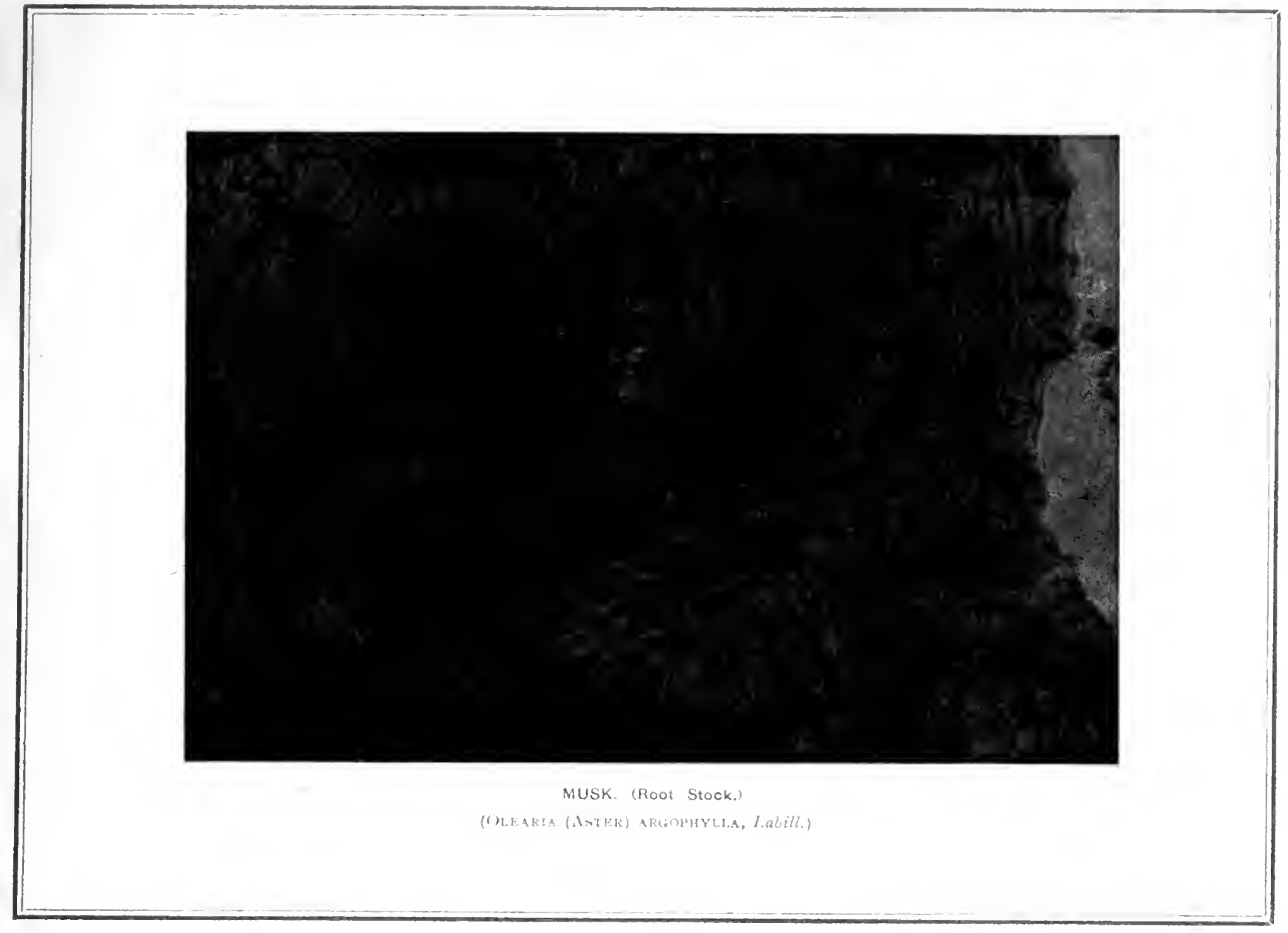




\section{MYOPORINE $Æ$.}

Tus is a Natural Order with a limited world distribution-the genus Eremophila-from which at least one specimen of cabinet timber is obtained, being endemic to Australia. "Budda," Eremophila Mitchelli, has an extensive range in the interior, and, unfortunately, has also had the name Sandalwood applied to it, which is likely to mislead timber dealers, as it is not the true Sandalwood of commerce, Santalum. However, with its characteristic features, it has a future before it.

Species Illustrated in Colour:-

Budda (Eremophila Mitchelli, Benth.). 


\title{
Budda or Sandalwood.
}

\author{
(Eremophila Mitchelli, Benth.)
}

In some parts of New South Wales and Queensland this tree is fairly plentiful. It is a comparatively hard, close-grained, sepia-coloured timber, possessing a pleasing aromatic principle, which has given it the common name of Sandalwood in some parts, an appellation that is unfortunate, for it has led to the wood being exported under that name, to the loss of the exporters. The true Australian Sandalwood occurs in Western Australia, and is Santalum acuminatum. This timber might, however, be used for veneers, boxes, brushes, and fancy or ornamental goods generally. It is rarely found on the Sydney market, as its habitat is away in the interior of the country. I

Description of the Tree.-A medium-sized tree ( 50 to 60 feet) with a rougl bark, and a strong aromatic timber. Leaves linear, lanceolate, I to 3 inches long, obtuse or with a recurved point. Flowers solitary in the axils on pedicels of about $\frac{1}{4}$ inch. Calyx segments oblong or cuneate-oblong, obtuse, membraneous veined, glabrous or pubescent, nearly $\frac{1}{2}$ inch long. Corolla white or purplish, almost $\frac{1}{2}$ inch long. Stamens shorter than the corolla. Fruit ovoid, almost acuminate, half as long as the calyx, the exocarp thin and membraneous, the endocarp separating into four nuts, each with one or with two superposed seeds.

Goographical Range.-Found in the interior of Queensland, New South Wales, and South Australia. 


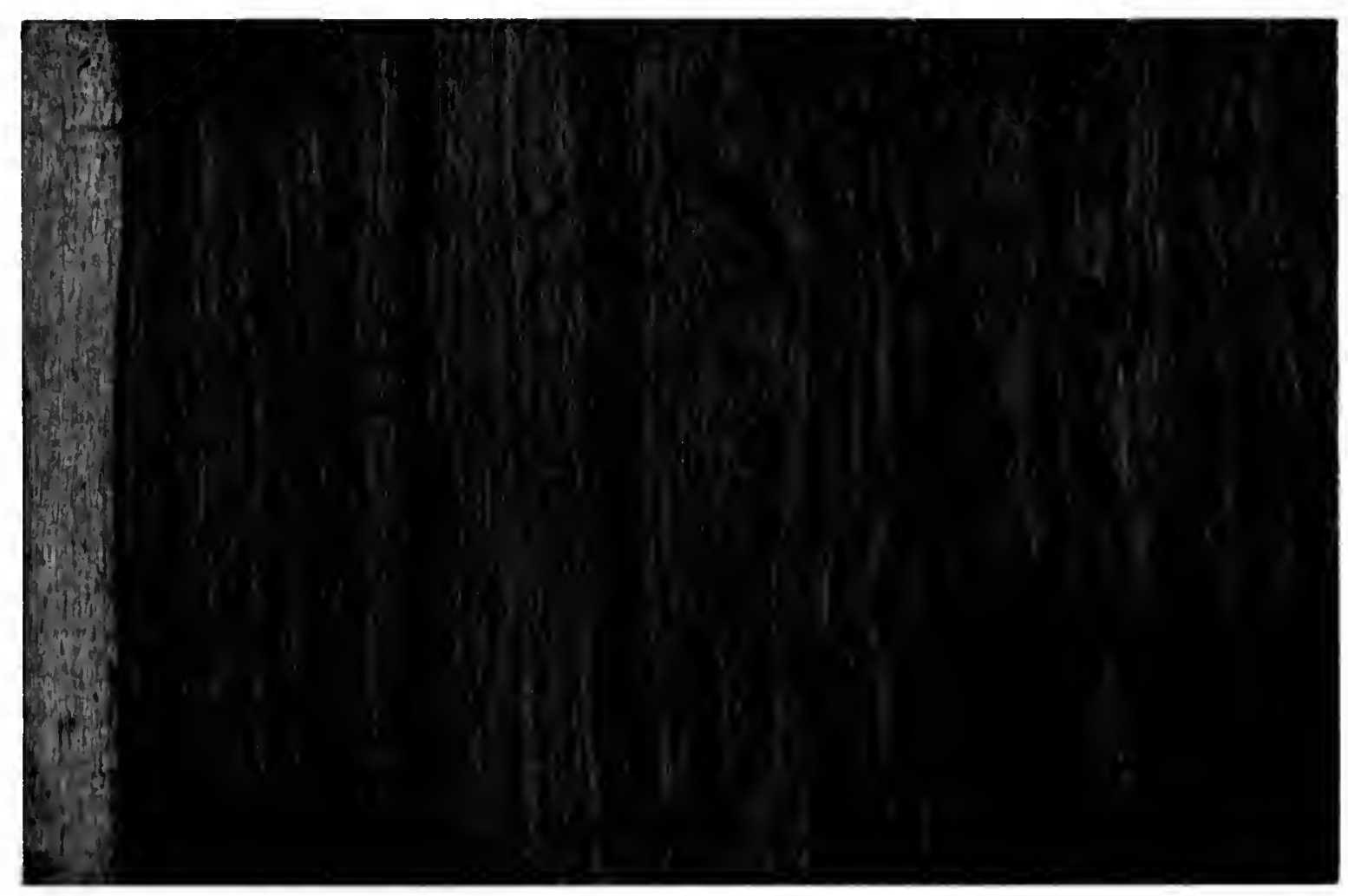

BUDDA.

(EREMOPHHA Mitchet.L, F., M. 
NATURAL ORDER.

\section{VERBENACE $Æ$. \\ $x$}

IT is from a genus of this Order that the famous Indian Teak is obtained, and its best representatives occur in the tropics, although some good specimens are found in the temperate zones. The finest trees in Australia are those going under the generic name of Gmelina, or commonly, in New South Wales at least, "Beech." Some of them are giants of the coastal brushes. The timber has been much more used in the past than at the present day, although still a favourite with wood carvers. There are several other good woods in the order, but they have not yet come to the front.

Species Illustrated in Colour :-

Beech (Gmelina Leichhardtii, F.v.M.). 


\section{Beech.}

(Gmelina Leichhardtii, F.v.M.)

The common name selected for this timber is unfortunate, as it is not a true Beech, like Negro-head Beech of New South Wales or the Red Myrtle of Tasmania. It is, however, too late to alter it now, but the warning is placed here that timber merchants abroad may not be misled. The timber, a light grey in colour, is highly prized by the trade in general, being light in weight, durable, easily worked, and strong. It is a great favourite with wood carvers, and is in general use for flooring (where exposed to weather), deck planking, and all kinds of turnery. It seasons s'owly and does not crack on the end grain.

Description of the Tree.-One of the tallest trees in the brush lands of the Eastern Coast. with a comparatively smooth, light-coloured bark. Leaves on long petioles (2 inches), ovate, large, up to and over 6 inches, glabrous above, tomentose and with raised veins underneath, subcoriaceous. Flowers white, with purple markings in opposite cymes or pyramidal terminal panicles. Calyx small, broadly-turbinate, campanulate, truncate, enlarged under the fruit. Corolla villous outside, the tube broad and dilated upwards. Fruit a succulent drupe, depressed, globular, under I incl diameter.

Geographical Range.-Southern brush forests, Queensland. and northern brush forest, New Soutl Wales. 


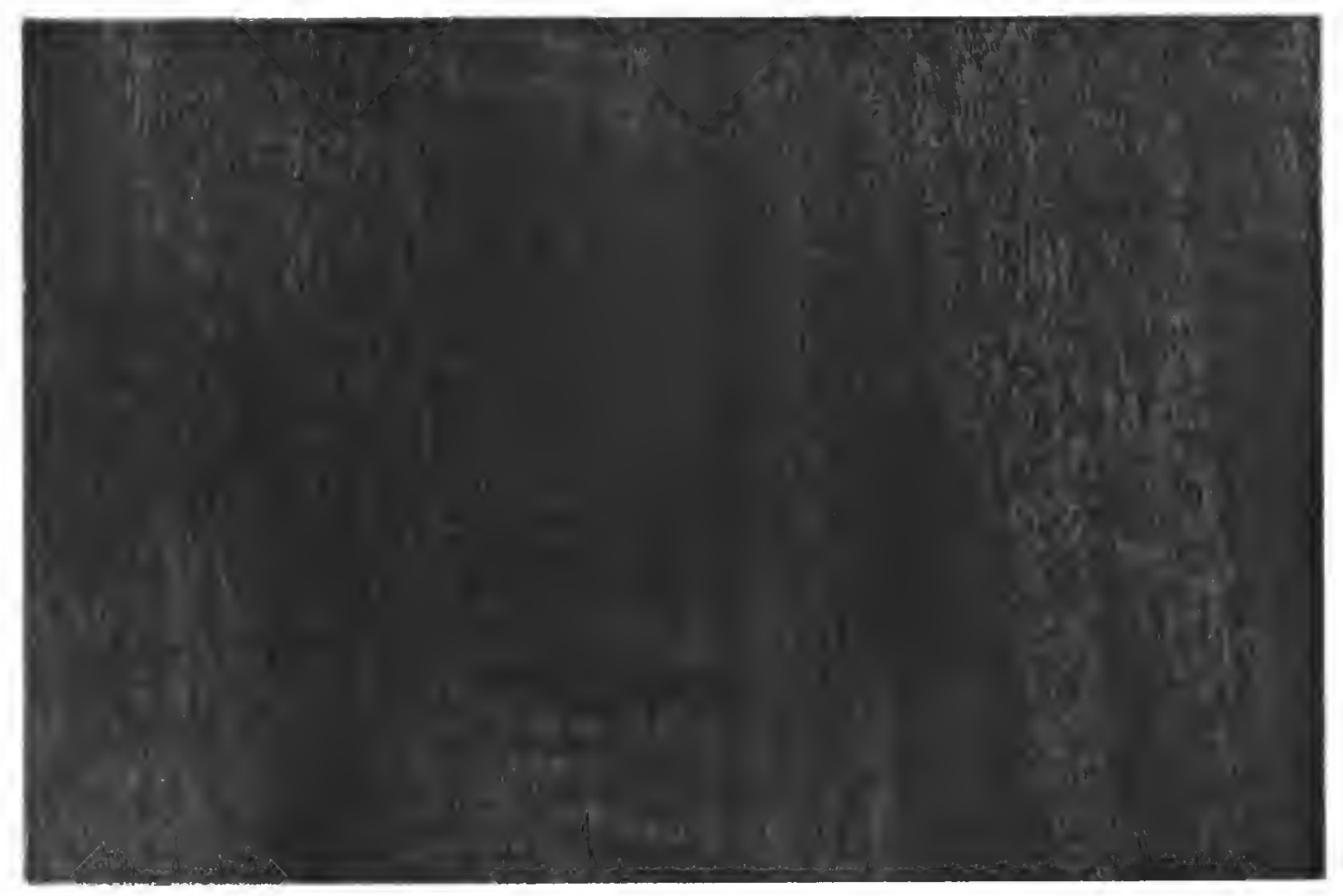

BEECH.

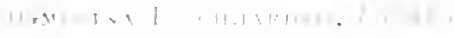


NATURAL ORDER.

\section{MONIMIACE $Æ$.}

A Rather limited Order, and found mostly in the southern continents. The two best representatives here amongst cabinet timbers are the Sassafras, Doryphora sassafras and Atherospima moschata. both fair timbers, the former teing light yellow in colour and without any particular figure, but the latter has often a very dark, irregular stain in long angular blotches, which produces a unique figure and looks well in panelling.

\section{Species Illustrated in Colour :-}

Sassafras (Doryphora sassajras, Encll.). 


\section{Sassafras.}

(Doryphora sassafras, Endl.)

This is a yellowish timber when first felled, but darkens when exposed so that it requires to be used almost as soon as cut, for it seasons quickly. Some specimens in the Museum have large black markings, which are not a figure as generally understood, but nevertheless give a very distinct feature, and should be effective if artistically employed. It is close-grained, light in weight, and dresses well. It is used for flooring, linings, mouldings, \&c., and cou'd to some extent be employed in furniture and cabinet work.

Description of the Tree.-A fairly tall tree, with a yellowish, tesselated, aromatic bark. Leaves petiolate, ovate lanceolate, acuminate, coarsely toothed, up to 6 inches long and $2 \frac{1}{2}$ inches broad, nearly smooth in upper surface, prominently reticulate on the under surface. Flowers usually three together on an axillary short peduncle, with two deciduous bracts. Perianth tube very small when in flower, enlarged and irregularly split when in fruit. Fruit, a capsule, slightly haily, the styles lengthening after fecundation into long plumose awns.

Geographical Range.-Logan River, Queensland, south to Dromedary Mountain, New South Wales. 
$\times 1.11$

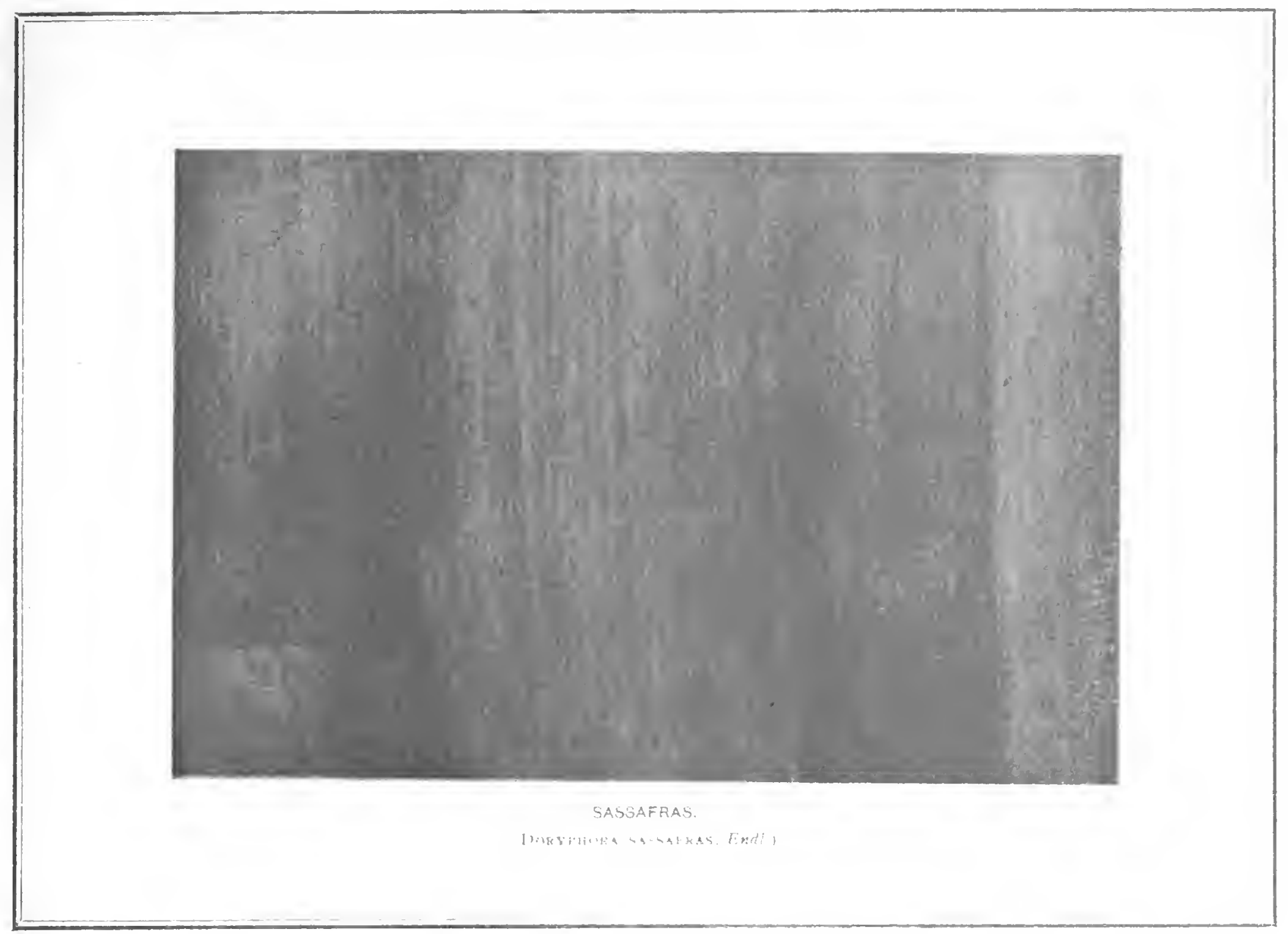


NATURAL ORDER.

\section{LAURINE E.}

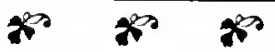

REPRESENTATIES of this Order are found in the four quarters of the globe, but they are essentially tropical trees, as there the species and genera are more numerous. The Camphor Laurel, so extensively grown in Australia, although not a native, belongs to this Order. Iost of the Australian trees yield good timbers for cabinet work, but are not used except in the case of Bolly Gum and Queensland Walnut, which often have a large, well-defined figure.

Species Illustrated in Colour:-

Queensland Walnut (Cryptocarya Palmerstoni, Bails).

Bolly Gum (Tetranthera reticulata, Meissn.). 


\section{Queensland Walnut.}

(Cryptocarya Palmerstoni, Bail.)

The botanical origin of this wood is rather in doubt at the present time. It is capable of being employed in cabinet work and artistic furniture, being very effective when so used. It is fairly heavy, of a chocolate colour near to English and American Walnut, rather open in the grain, planes and dresses up well, takes a good polish, and possesses a fine figure, and hence ranks as a first-class cabinet timber, its position in this direction being due, amongst its other qualities, to its quick seasoning. It is altogether a good useful joinery and cabinet wood.

Description of the Tree.-A tree of a large size, attaining a height of over yoo feet. Leaves alternate, oval oblong, rounded or slightly tapering at the base, 4 to 5 inches long and about 2 inches broad, upper surface glabrous and shining, with a tomentum on the lower side; primary veins prominent, secondary veins indistinct. Fruit about $2 \frac{1}{2}$ inches long and about the same in diameter, with longitudinal corrugations, pericarp hard and brittle, enclosing a round free nut of more than I inch diameter.

Geographical Range.-Russell and Barron Rivers, Queensland (Bailey). 


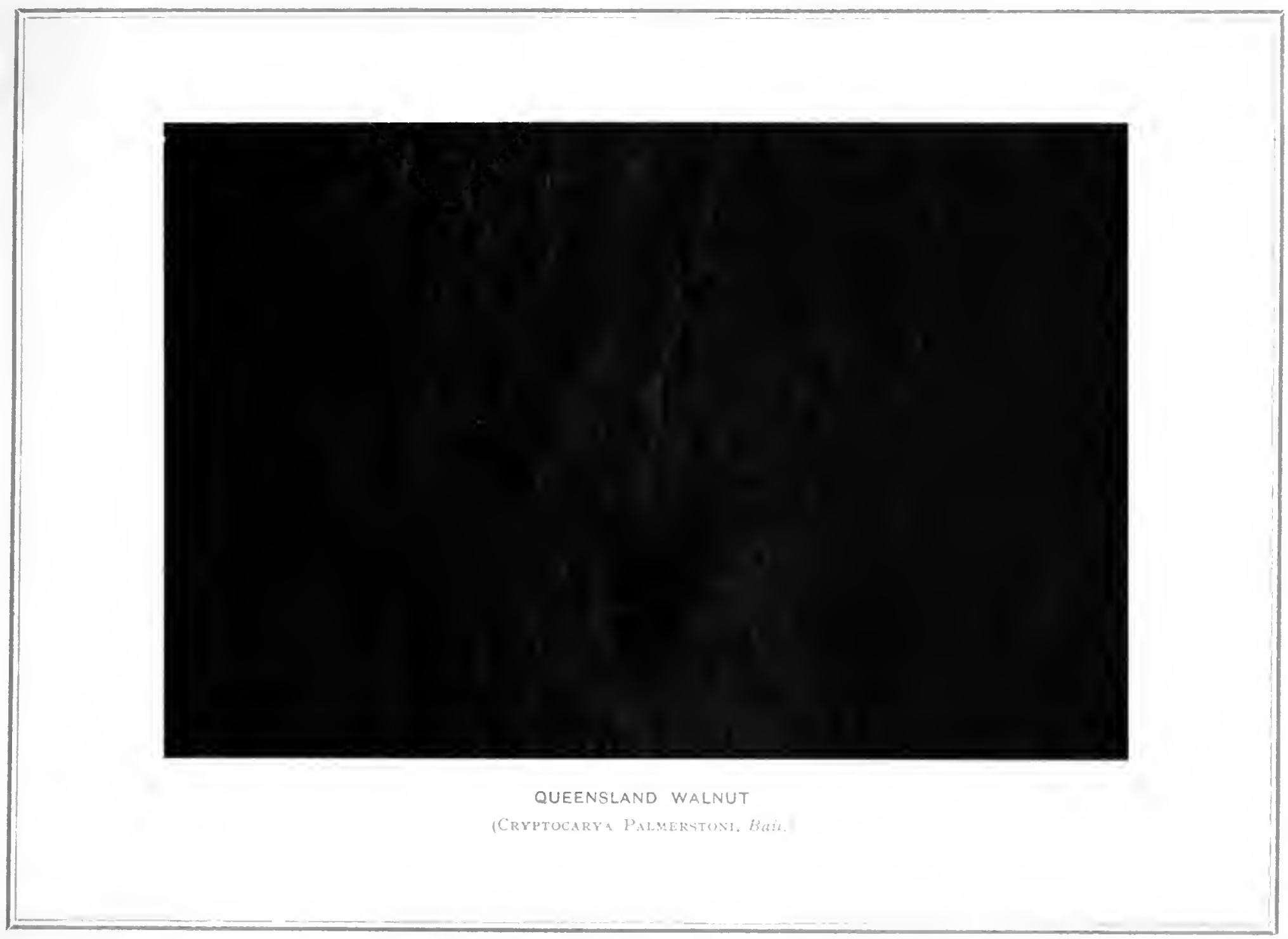




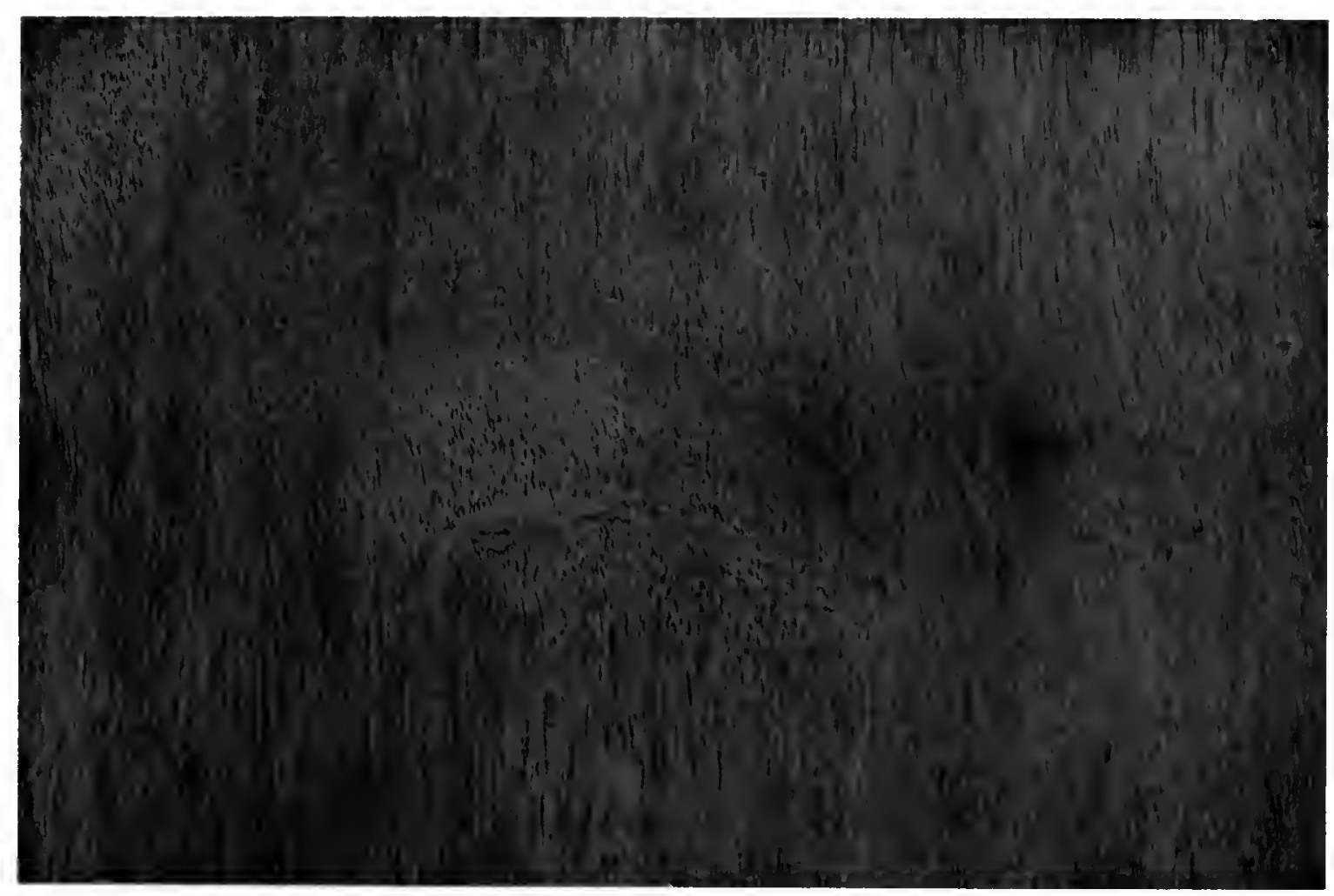

SHE BEECH OR BOLLY GUM.

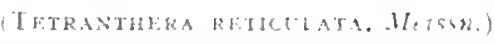


. 


\section{She Beech or Bolly Gum.}

(Tetranthera reticulata, Meissn.)

It would be difficult to explain the origin of the vernacular names, as the timber has little in common with other Beeches. The wood is rather open in texture, soft, and a pronounced figure often characterises it, when it looks very attractive under polish, which it takes very well. It is light in weight, and seasons quickly, whilst it does not warp or twist under heat. In joinery it could be used for panelling, sashes, sash frames, and fanlights, but care should be taken not to use any sapwood on account of borers.

Description of the Tree.-A full-sized tree, having a thin, smoothish, reddish-coloured bark, but sometimes rough and tesselated. Leaves obovate-oblong or oblong-elliptical, obtuse or scarcely acuminate, narrowed into the petiole, mostly 3 or 4 inches long, not thick, green on both sides; primary veins not very prominent, the reticulations much more conspicuous on the upper than on the lower surface. Flowers diccious, in cymes reduced to small umbel heads or clusters within an involucre of four concave'deciduous bracts. Fruit ovoid, resting in the enlarged, truncate, cup-shaped perianth-tube::

Geographical Range.-From Rockingham Bay, Queensland, south to Gosford, New South Wales. 
NATURAI. ORDER.

\section{PROTEACE $Æ$. \\ $x$}

In this Natural Order Australia possesses some of the finest of figured cabinet timbers, and perhaps the best known of these is "Silky Oak," as the two species going under this name have a fairly extensive gecgraphical range in New South Wales and Queensland. There are other beautiful woods to be found in it, such as:-

Silky Oak (Grevillea robusta. A. Cunn.).

Nut Tree (Macadamia ternifolia, F.v.M.).

Honeysuckle (Banksia species).

Beefwood (Stenocarpus salignus, R.Br.).
Needlewood (Hakea lecucoptera, R.Br.!.

Foley Wood ( $H$. saligna, R.Br.).

Possum Nut (Helicia praalta. F.v.1I.).

\section{Species lllustrated in Colour :-}

Silky Oak (Orites excelsa, R.Br.).

Beefwood (Grevillea striata, R.Br.).

Victorian Waratah (Telopea oreades, F.v.M.).
Tasmanian Waratah ( $T$. truncata, R.Br.).

Fire Tree (Stenocarpus sinuatus, Endi.).

White Honeysuckle (Banksia integrifolia, Linn.). 
XI.

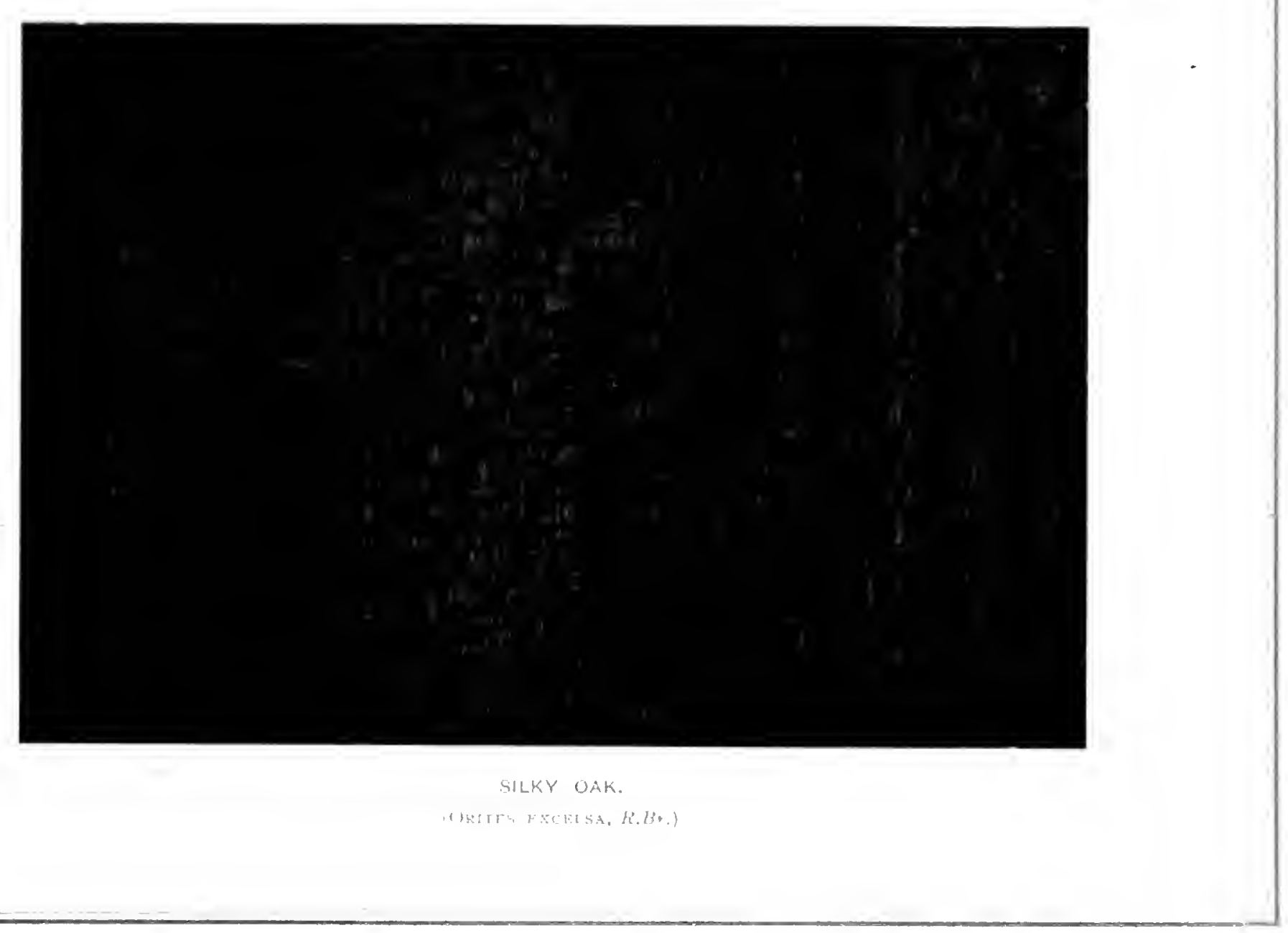




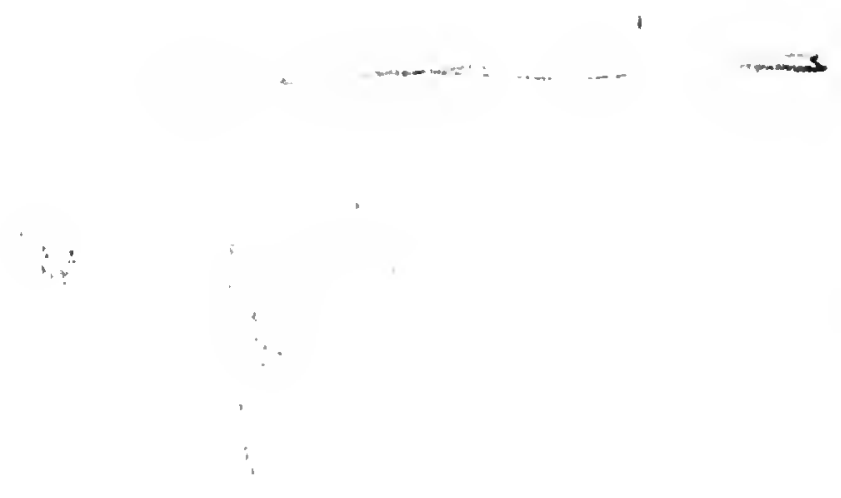




\section{Silky Oak.}

(Orites excelsa, R.Br.)

A description of the timber of "Silky Oak" (Grevillea robusta) applies equally to this timber, for macroscopically there is no difference. The wood of this species, according to the researches of Henry G. Smith, F.C.S., Assistant Curator of this Museum, contains large quantities of succinate of alumina in some instances. It is, however, more frequently placed on the market than $G$. robusta, and is extensively used in cabinet work, the figure being its chief recommendation in this connection. It is a timber much in request by coachbuilders, and also saddle makers, who assert that it has a capacity for holding nails not possessed by other timbers. It is strong and durable, with a beautiful figure, being suitable for any kind of office or shop fittings, general cabinet or joinery work. If the natural colour is not acceptable it can be stained to any shade without obscuring the grain. The timber of this species may always be distinguished from that of Grevillea robusta by the presence of large quantities of alumina in the ash of the former.

Description of the Tree.-A very tall and stout tree of the brush lands of the coast, with a thin, red, smoothish bark, having a coating of white. Leaves on the flowering branches lanceolate, obtuse or acute, tapering into a rather long petiole, entire or slightly toothed, 4 to 6 inches long, reticulate, shining above, glaucous underneath; those of the barren branches often larger, toothed or deeply divided into three or five lanceolate toothed lobes. Flowers small in axillary spikes, sessile or nearly so, in pairs within each bract, interrupted shorter than the leaves, usually glabrous, the flowers in distinct pairs. Perianth glabrous, under $\frac{1}{4}$ inch long. Fruit a follicle, acuminate, about I inch long. Seeds flat, under $\frac{1}{2}$ inch long.

Geographical Range.-This occurs in the brushes of the North Coast of New South Wales and coast of Queensland. 


$$
\text { 단 }
$$




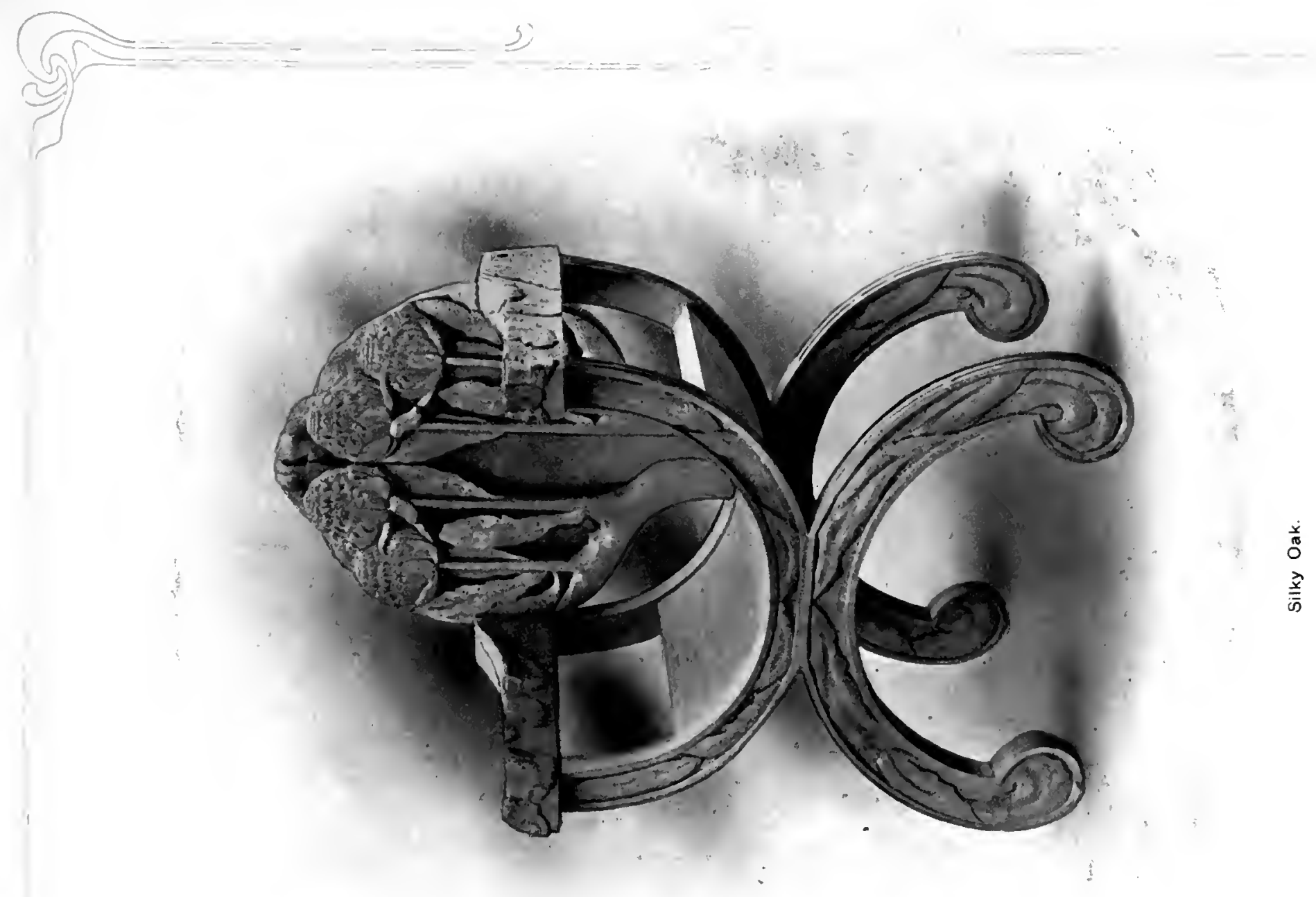




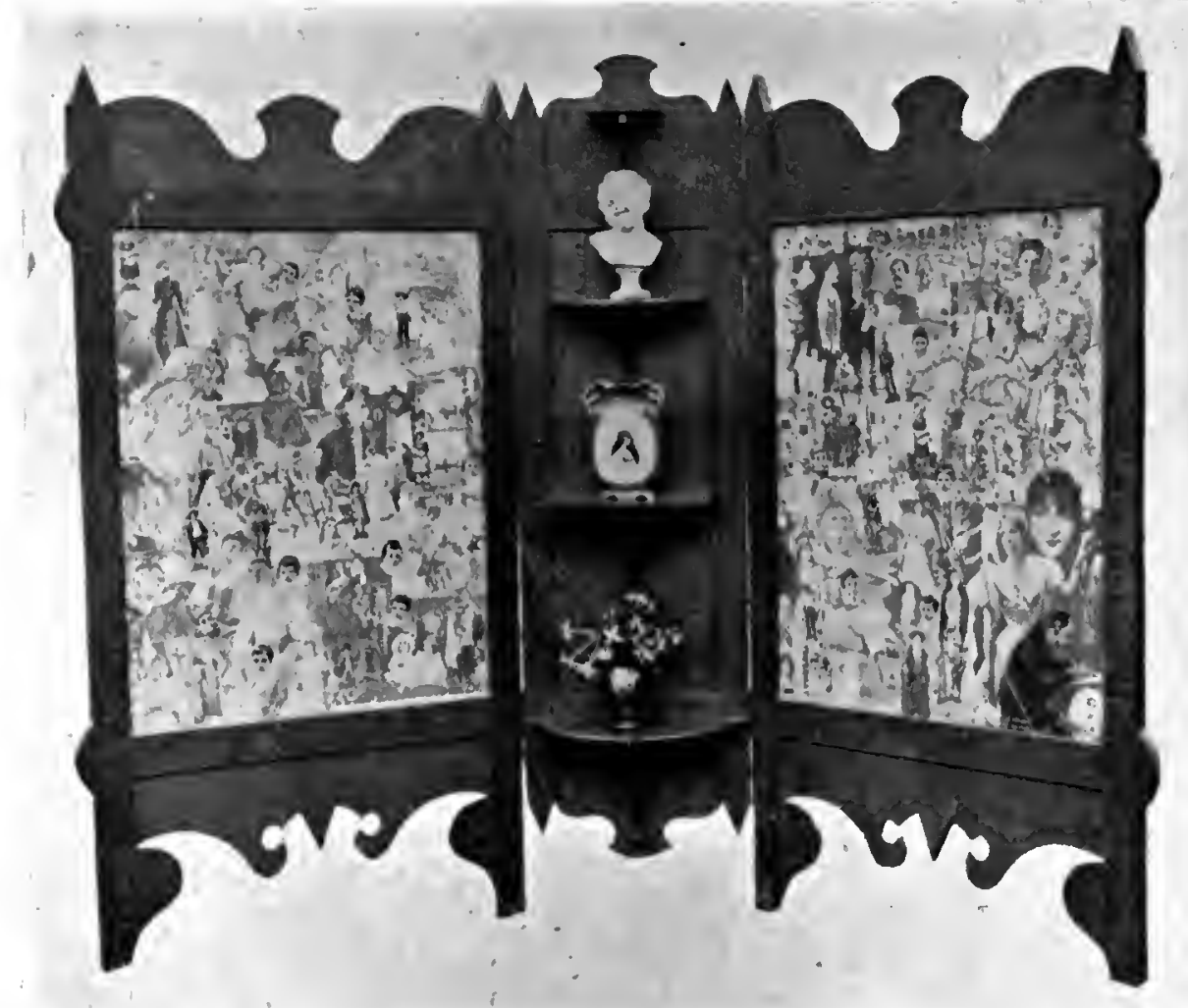

Silky Oak Screen. 


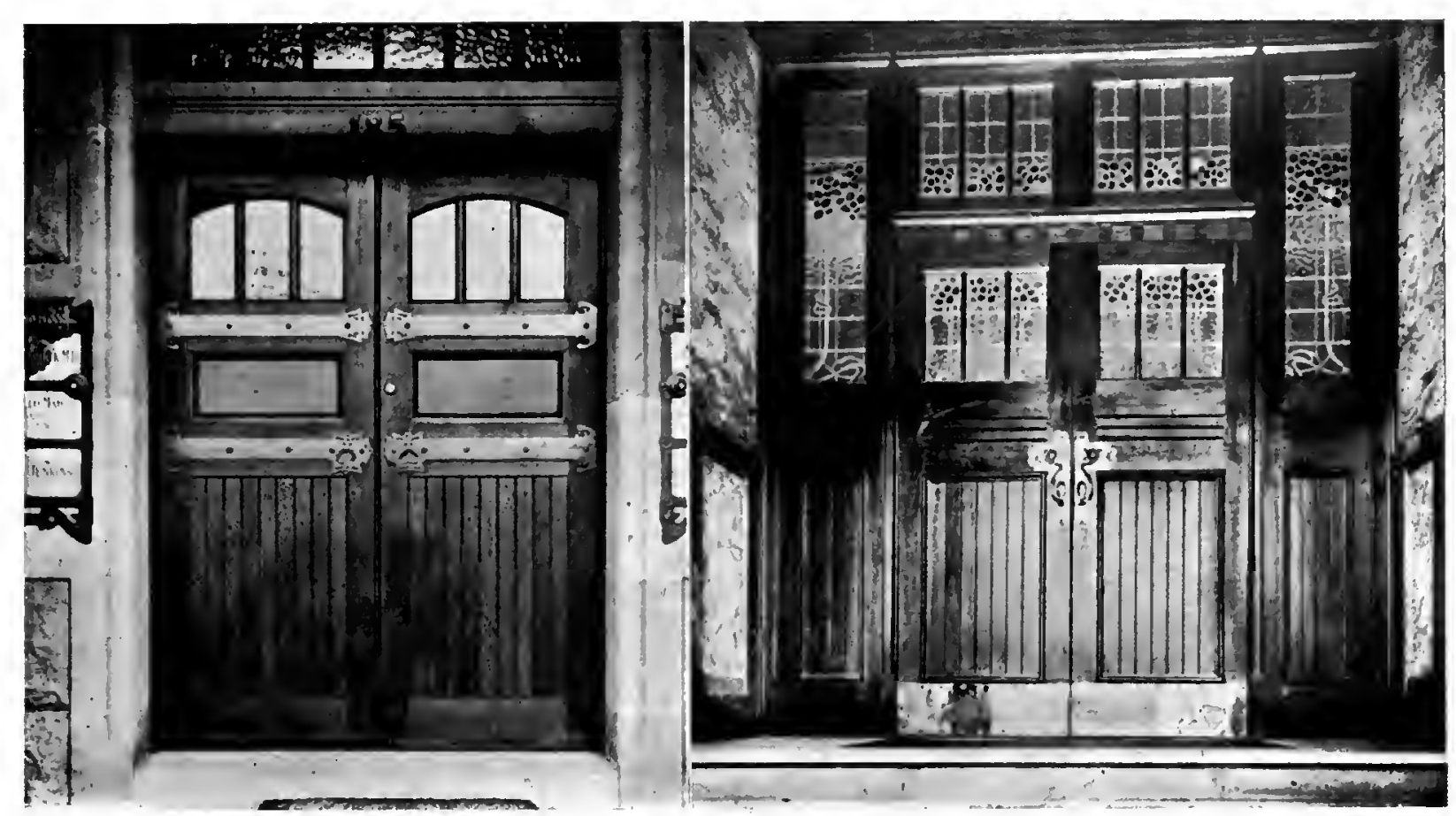

Macquarie-street, Sydney.

Silky Oak Doors.

Y.MI.C.A., Sydney, 


\section{Beefwood.}

(Grevillea striata, R.Br.)

This timber is characterised by a pronounced "Oak" figure and a deep red colour, from which it takes its vernacular name. The tree attains a fair height, so that some good flitches can be produced. It is rather open in the grain, but dresses well and takes a good polish, is fairly heavy, and for decoration in heavy cabinet work would be very suitable; but so far has not been used in the trade, as it is not a common tree, and so is seldom found in the eastern markets. It should look well in all kinds of ornamental boxes, brushes, cutlery cases, scientific instrument cases, \&c.

Description of the Tree.-A large tree with a great geographical range, found on the north and east coast and extending into the dry interior of the continent, with a rough, thick, furrowed bark. Leaves undivided, linear or linear-lanceolate, 6 to I 8 inches long, often curved, from under a quarter to over $\frac{1}{2}$ an inch broad, striate underneath, with nine to thirteen raised parallel nerves. Flowers small, in slender spike-like erect racemes of 2 or 3 inches, shortly pedunculate, and usually several together in a leafless panicle shorter than the leaves, the rachis tomentose. Pedicels very short, perianth silkypubescent outside, glabrous inside. Ovary glabrous on a slender stipe. Fruit broad, very oblique, compressed, about $\frac{3}{4}$ inch long.

Geographical Range.-All the States but Tasmania. 
1.11.

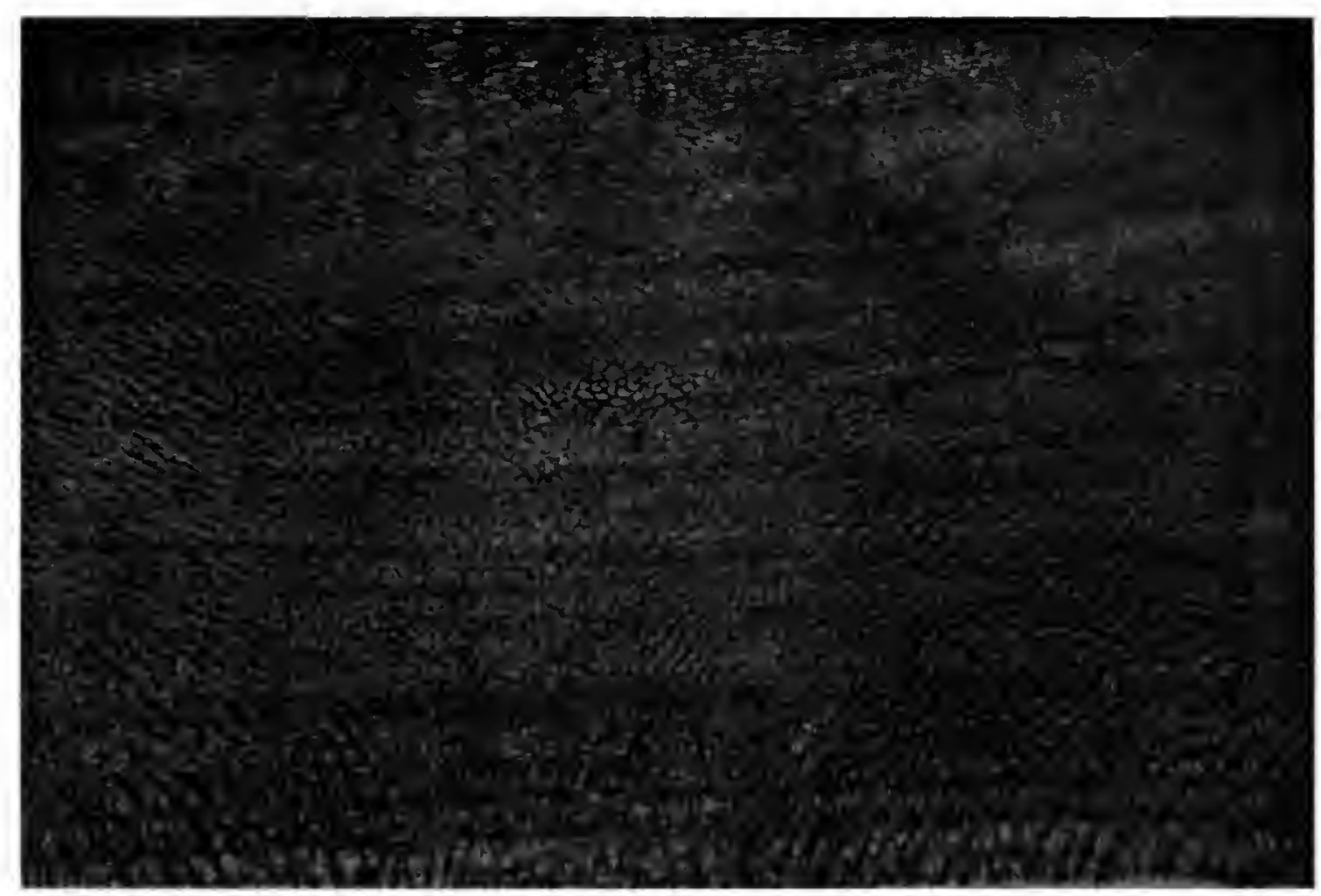

BEEFWOOD

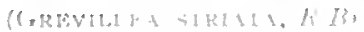


$-3$

\section{!}

s 


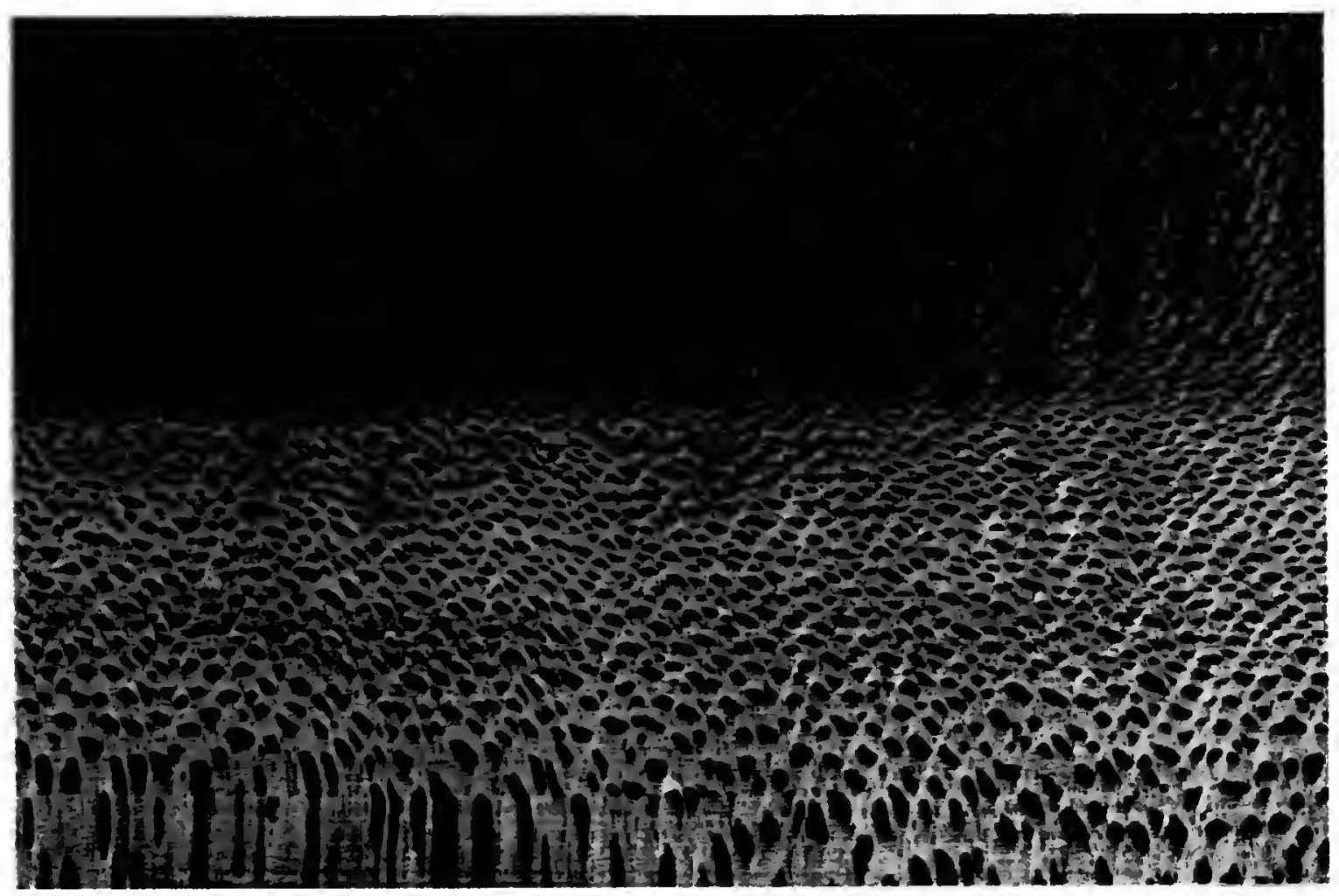

VICTORIAN WARATAH.

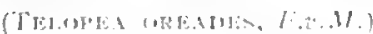




\section{-}

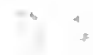




\title{
Victorian Waratah.
}

\author{
(Telopea oreades, F.v.M.)
}

Here is one of our prettiest figured Australian ornamental timbers. In figure, character, and texture it is a replica of the American Sycamore, so much admired in light-coloured suites of furniture, and so largely used in veneers for decorative work. At one time the latter timber was much in vogue for picture frames, but is not now so used. It is a close grained, medium in weight, light coloured timber, which planes and polishes well, and only requires to be better known to be appreciated in the trade.

Description of the Tree.-A fair sized tree with a very thin, fairly smooth, dark coloured bark. Leaves on the young plants large, a foot long, and nearly 3 inches wide, oblanceolate, acuminate, much narrowed towards the base. A few of the main reins prominent, glabrous pale on the under side. Normal leaves alternate, obovate-oblong, entire 4 to 8 inches long, tapering into a long petiole, glaucous underneatl. Flowers crowded in a large terminal crimson head-like raceme, surrounded by comparatively small coloured involucral bracts, under $I$ inch long. Perianth glabrous, over I inch long. Fruit a recurved coriaceous follicle about 5 inches long.

Geographical Range.-Southern Coast district, New South Wales, into Gippsland, Victoria. 


\title{
Tasmanian Waratah.
}

\author{
(Telopea truncata, R.Br.)
}

A rather small tree, with timber having a figure similar to the Victorian Waratah, but having a darker heartwood; of a pale red colour. It could be utilised in the smaller kinds of cabinet work.

Description of the Tree.-A much smaller tree than the Victorian Waratah, abont 20 feet being its maximum height, which appears to be the only distinguishing feature from that species. The leaves perhaps are a shade shorter than that species.

Geographical Range.-Tasmania, principally on the Mountains. . 


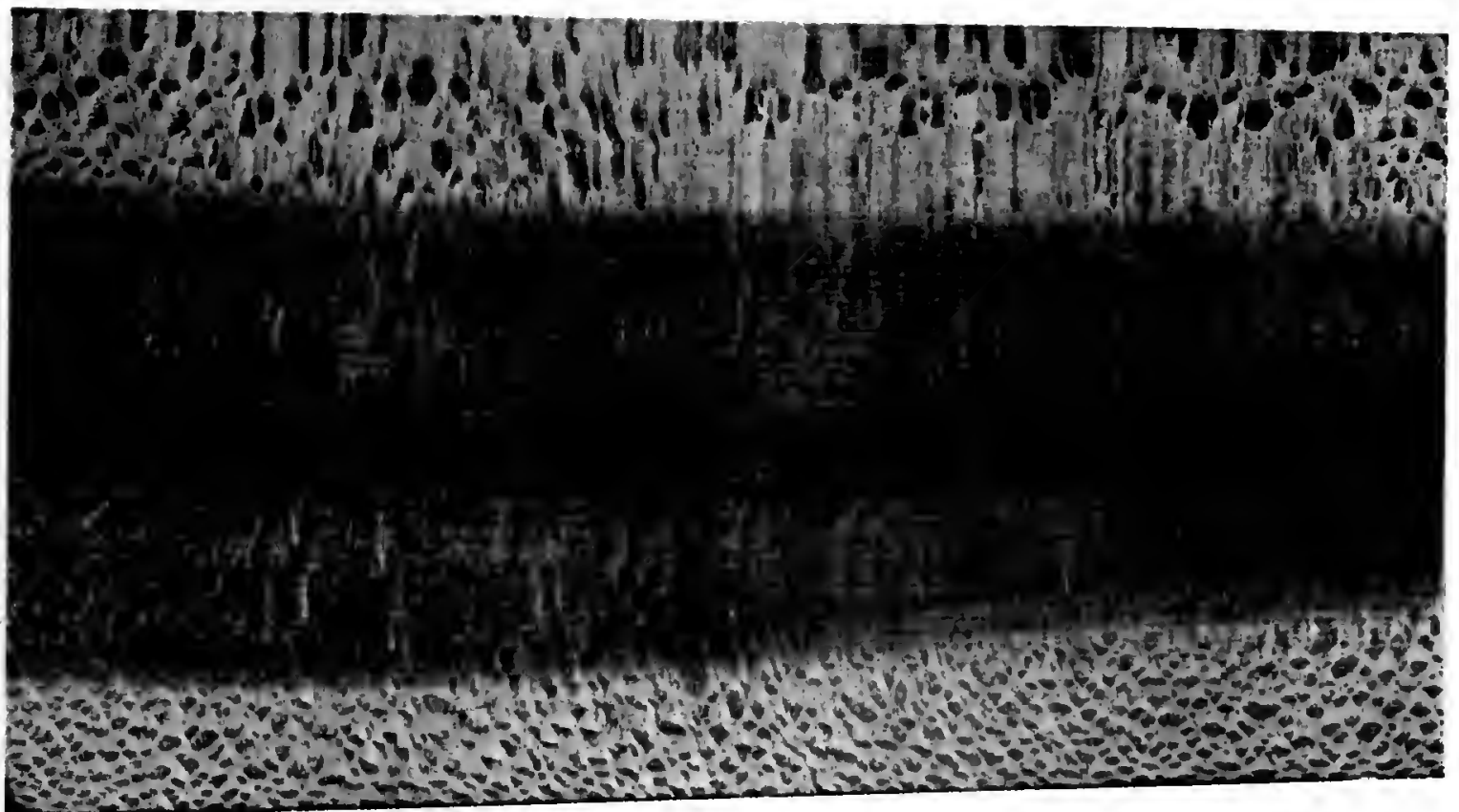

TASMANIAN WARATAH.

(TEIOPEA TRUNCATA, R.Br.) 


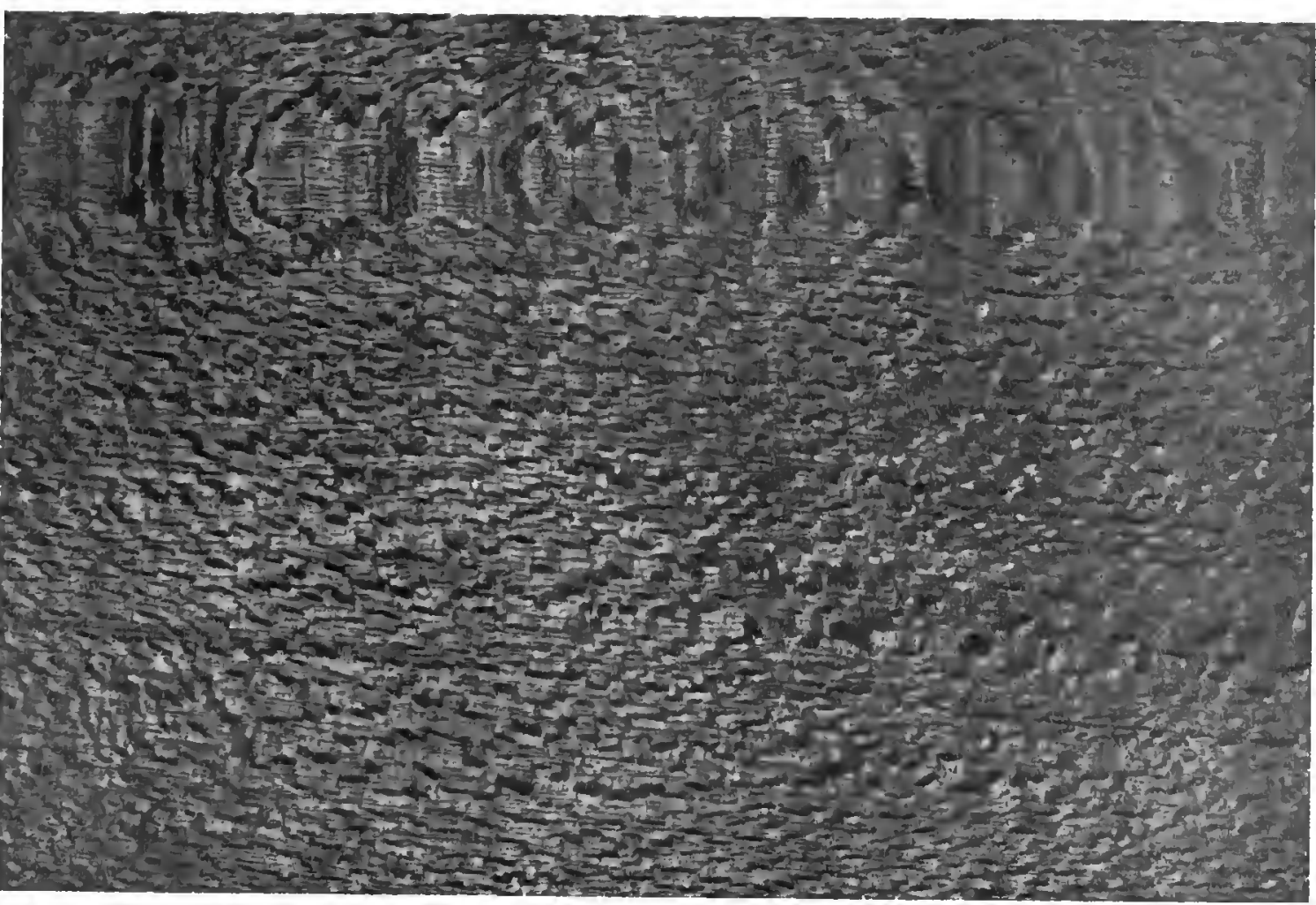

FIRE TAEE

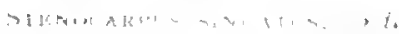




\section{Fire Tree.}

(Stenocarpus simuatus, Endl.)

A most attractive, delicate-looking wood, being light in colour, and fairly so in weight. The medullary rays are comparatively small, but showy, having a sheen, and embedded in the paler tracheids of the secondary wood, thus stand out very distinctively. It is somewhat like American Sycamore, and is not easy to distinguish from it in general facies. It dresses well and takes a good polish, and could be used for indoor decoration and furniture with most artistic effect. This timber much resembles Silky Oak (Orites excelsa), and is suitable for any purpose for which English, American or Silky Oaks are adapted.

Description of the Tree.-A large tree of the brush lands of the coast, having a fairly smooth bark. It is often found in cultivation on account of its showy and remarkable flowers. Leaves either entire and oblong-lanceolate, and 6 to 8 inches long, or pinnatifid, and above I foot long, with one to four oblong lobes on each side mostly obtuse, quite glabrous or reddish underneath, penniveined. Flowers in umbels on axillary peduncles, each peduncle 2 to 4 inches long, twelve to twenty bright red flowers in each umbel, radiating in a single row round the disc-like dilated summit of the peduncle. Perianth tube about I inch long. Fruit a follicle, narrow, coriaceous; seeds produced at the lower end into a membraneous wing.

Geographical Range.-Occurs in the brushes of the North Coast of New South Wales and Southern Queensland. 


\section{White Honeysuckle.}

(Banksia integrifolia, Linn.)

In this species of Proteaceæ we have another characteristic timber of the genus as regards figure, but not so in texture, strength, and colour, for being light and strong, it is the most suitable timber for flying machines yet tested at this Museum. It could be used most effectively for panelling if cut on the quarter or otherwise. It takes a good polish, works fairly well, is an ornamental timber of a distinctive nature, and is suitable for almost any kind of fancy or decorative work, the colour and figure being attractive.

Description of the Tree.-A tree attaining the full size of a forest tree. Leaves obtuse, retuse, or pointed, scattered, lanceolate to oblanceolate, sometimes irregularly verticillate, quite entire or irregularly toothed, up to 9 inches long, white underneath, with transverse veins more or less distinct, shining and smooth above. Flowers strawcoloured, silky-pubescent, sessile in pairs round the thick rachis of a large dense terminal spike 5 inches long and 2 inches in diameter, bracts and bracteoles villous. Fruit a capsule consolidated with the rachis in a thick, woody, cylindrical-like mass, slightly tomentose or almost glabrous.

Geographical Range.- Coastal ranges and districts of Victoria, New South Wales, and Queensland. 


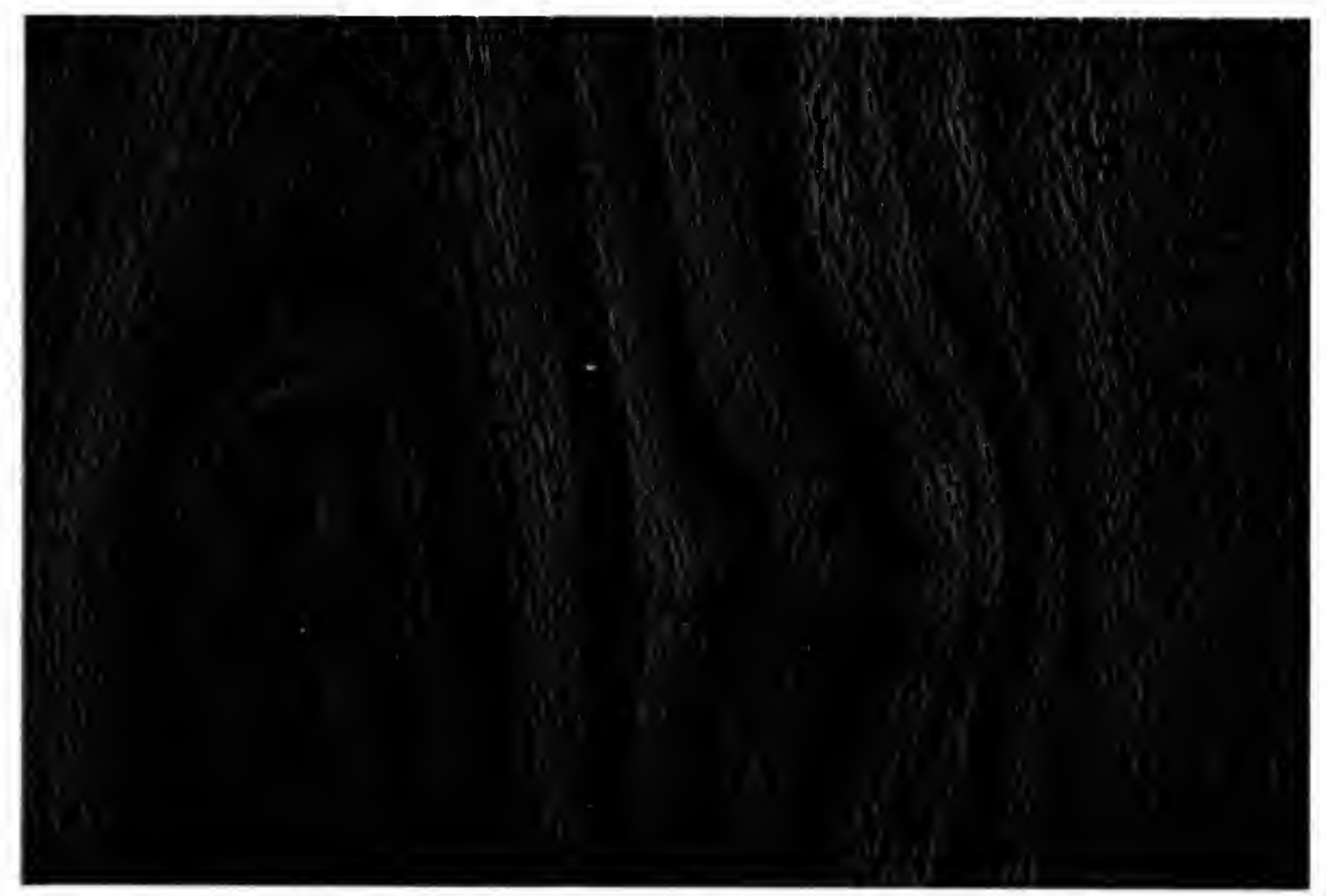

WHITE HONEYSUCKLE. PPlain Figure.

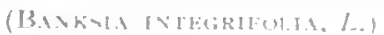




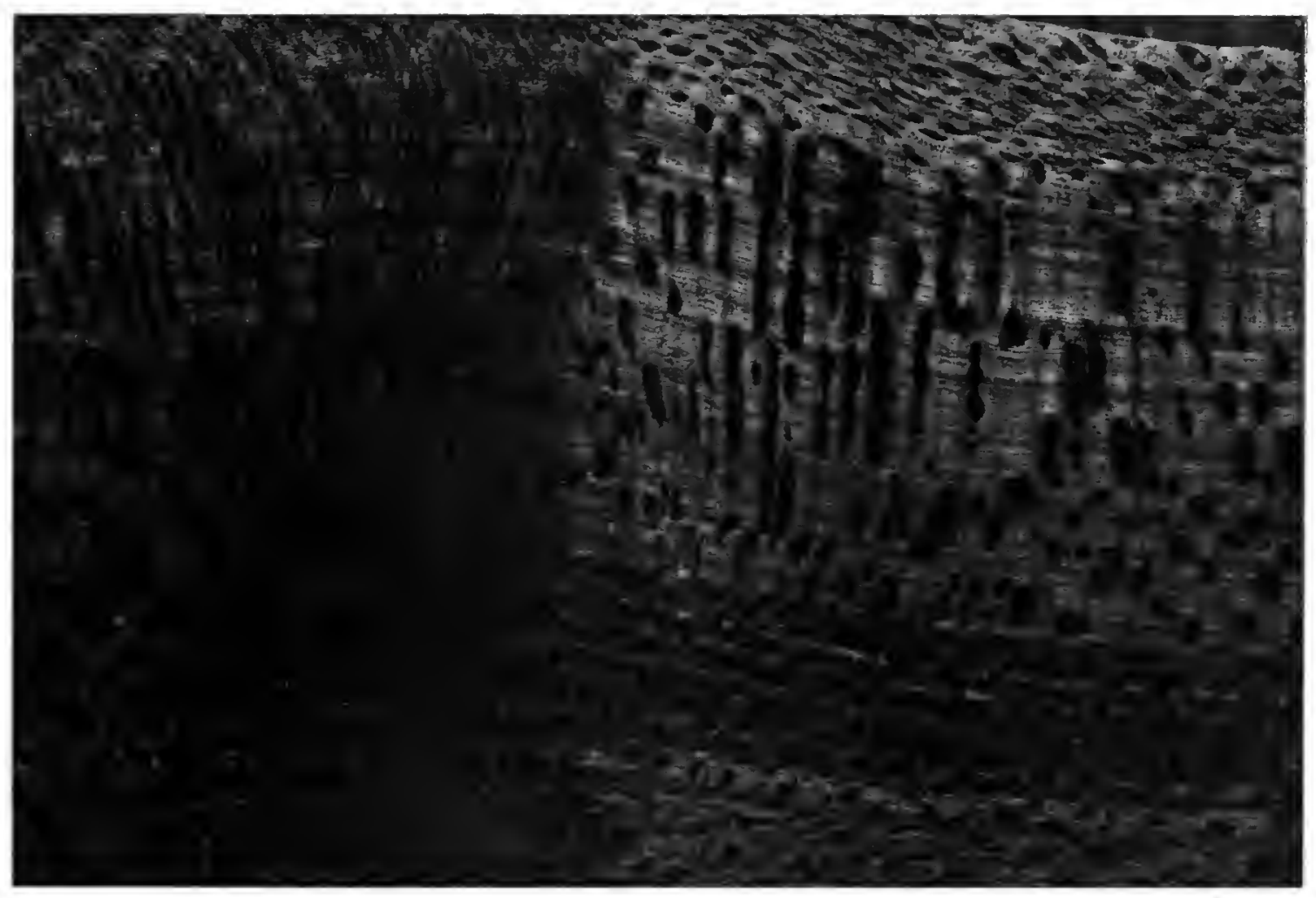

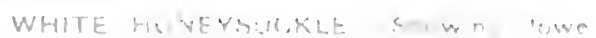

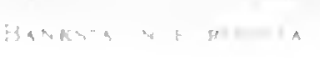


NATURAL ORDER.

\section{CASUARINEÆ.}

is if $\quad$ is

THE "Oak" figure of these woods is so well marked that in Australia they, with"one exception, are called "She Oaks," but are often designated specifically under' such names as Swamp Oak, Bull Oak, Forest Oak, River Oak Mountain Oak, \&c. The one exception is "Belah" (Casuarina Cambagei), and, strange to relate, the absence of any figure, or, for the matter of that, any resemblance to the wood of its congeners, is so marked, that the man on the land refuses to acknowledge its claims to rank as an "Oak." These trees are plentiful in certain parts of the States, so that if the trade could be prevailed upon to start a fashion in our "Oaks," Australians would have furniture that would compare with any ornamental timbers of other countries. The wood is heavy, but not more so than English Oak. The Belah wood more nearly approaches Walnut in colour and texture, but is rather heavier. It has not, however, the figure of commercial Walnut.

\section{Species Illustrated in Colour :-}

Swamp Oak (Casuarina glauca, Miq.).

Bull Oak (Casuarina Leuhmanni, R.T.B.).
Belah (Casuarina Cambagei. R.T.B.).

Forest She Oak (Casuarina torulosa, Ait.). 


\section{River Oak.}

(Casuarina Cunninghamii, Miq.)

Amongst Australian "She" Oaks this species ranks as the largest, for some fine noble specimens are to be found on the banks of fresh-water streams included in its range. The timber rarely reaches the Sydney markets, as the trees are scarcely ever cut down, being regarded, perhaps, as a necessary adjunct to the riverscape. The wood takes a good polish, although hard, having a close texture. The heartwood is pale chocolate in colour, and the outer portion almost white. The figure is well brought out on the quarter, and looks elegant in panelling, drapery poles, rods, \&c., and it should make up well in heavy furniture, and in carving; although of course it is hard-but so is English Oak, which is perhaps more carved than any other timber. It is very strong and durable, and for this reason it is utilised for bullock yokes in some places, but care is required in seasoning. The two distinctive colours would give it a unique appearance in turnery, such as serviette rings, cornice pole rings, \&c.

Description of the Tree.-One of, if not the largest tree of the genus, occurring on the banks of fresh-water streams or rivers. The timber is the palest of all the Casuarinas. The branchlets are slender and wiry, with usually seven teeth in the whorl. Fruiting cones are small, scarcely exceeding $\frac{1}{4}$ inch in diameter.

Geographical Range.- Coastal ranges and districts, and central New South Wales and Queensland. 


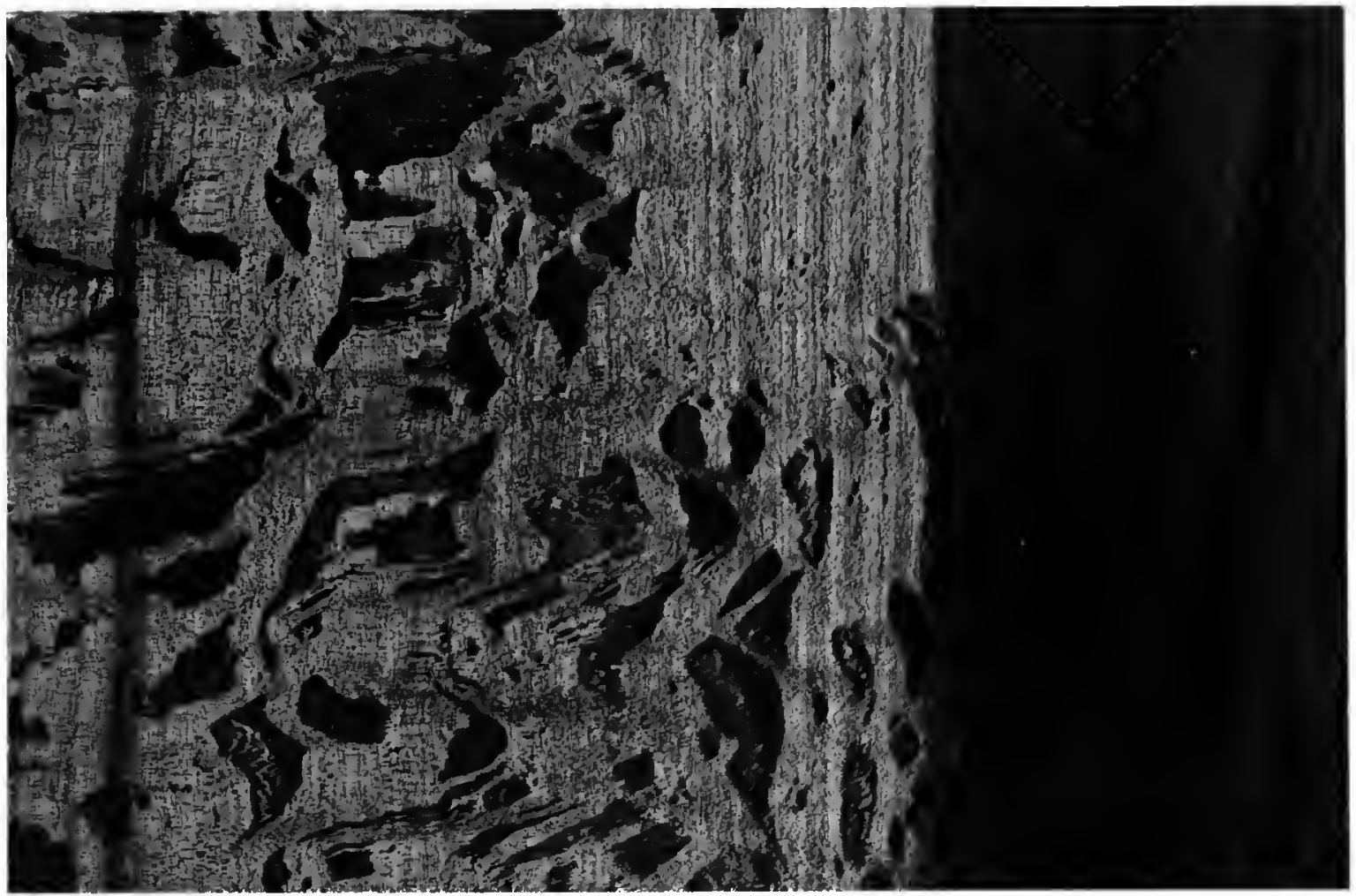

SWAMP OAK.

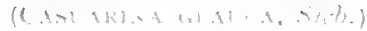




\section{Swamp Oak.}

(Casuarina glauca, Sieb.)

As the common name implies, this tree, which attains a considerable height, with a corresponding diameter, occurs in the river swamps of the coast, and does not extend far inland. The flitches have limited dimensions, but nevertheless of sufficient sizes to be utilised in many ways in cabinet work, either in the solid or veneers. It is a particularly hard, close-grained wood, and the medullary rays, being well pronounced, show a "flower" when cut on the quarter; but what gives an additional value to the figure is the dark, almost black duramen or heartwood, which is peculiar to this species amongst "She Oaks." It takes a good polish, but is rather difficult to dress by hand, but this slight defect does not obtain when machine prepared. When one sees how the English Oak was used so extensively in the past, and even now, for furniture, this timber could certainly be used for some of the purposes to which that noble timber has been utilised. It should make, in the solid, beautiful hall stools, benches, tables, dining chairs; and in veneer, many are the directions in which it could be used, as well as for coachbuilding in various ways. Such a wood certainly deserves more appreciation in the directions here particularised than has been bestowed upon it in the past, but is only used at present for firewood.

Description of the Tree.-A very fair-sized tree found growing in water-courses or banks of the streams that flow east in the coastal district, but always near salt water. The bark is very compact and hard, and fairly rough. Branclilets slender and wiry, drooping. The leaves are very slender and adnate to the branchlets on one side, the upper free end being called teeth or scales. These leaves vary in number and length, according to the species, and give the branchlets a ribbed appearance; in this case the number varying from nine to sixteen. Flowers unisexual, the males in cylindrical spikes, $\frac{1}{2}$ to I inch long, the females in globular or ovoid spikes or cones, both sexes sessile and solitary in the axils of the whorled leaf tips. Fruit a short cylindrical compact cone, flat topped, about $\frac{1}{2}$ inch in diameter, made up of numerous whorls of woody bracts. Seed compressed laterally, smooth and shining, produced at the apex in to a membraneous wing.

Geographical Range.-Coastal districts of South Australia, Victoria, New Soutl Wales, and Queensland. 


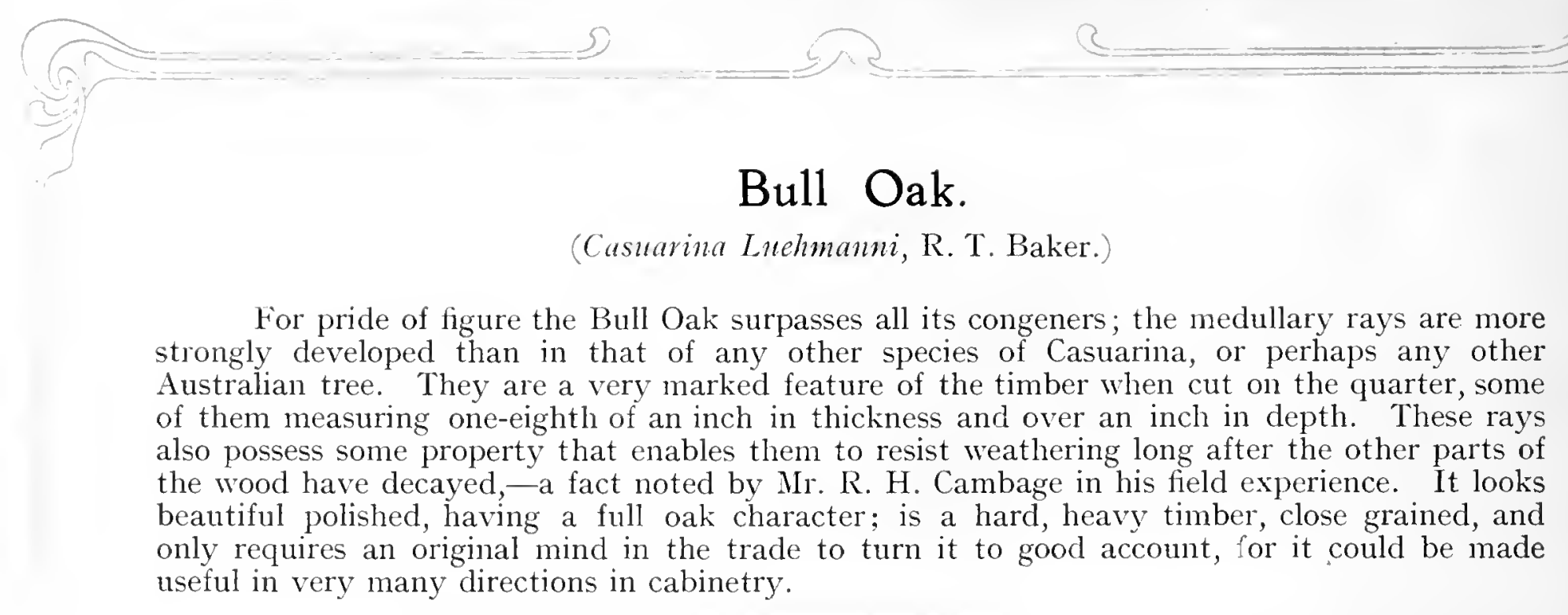

Description of the Tree.-A fair-sized tree, attaining a height of 70 to so feet, or rarely Ioo feet, and a diameter of from I to $I_{\frac{1}{2}}$ feet, rarely 2 feet. Bark furrowed, brittle and easily removed. Branchlets robust, light coloured or glaucous, under a line $\left(\begin{array}{l}3 \\ 4\end{array}\right)$ in diameter, about the same thickness as in C. glauca; the internodes ribbed, 6 lines long. glaucous, the nodes yellow, sheath teeth brown or black, short, acute, nine to twelve in the whorl, mostly eleven. Flowers dicecious. Male spikes about an inch long, of a light golden-brown colour, clustered at the nodes toward the end of the branchlets; internodes straw coloured, teeth golden coloured, erect, short acuminate, constricted at the nodes. Fruit cones flattened, about $\frac{1}{2}$ inch in diameter, and consisting almost uniformly of three discs or rows of valves, but often irrerularly shaped, owing apparently to only a few of the seeds being developed. Valves protruding, prominent, sometimes pubescent at the back and front, with a well defined dorsal protuberance extending from the base of the valve to half its length and ending in an abrupt angle. broadly obtuse or shortly acuminate. Nuts small, dark brown, shining, with a short samara.

Geographical Range.-Interior of New South Wales and Queensland. 


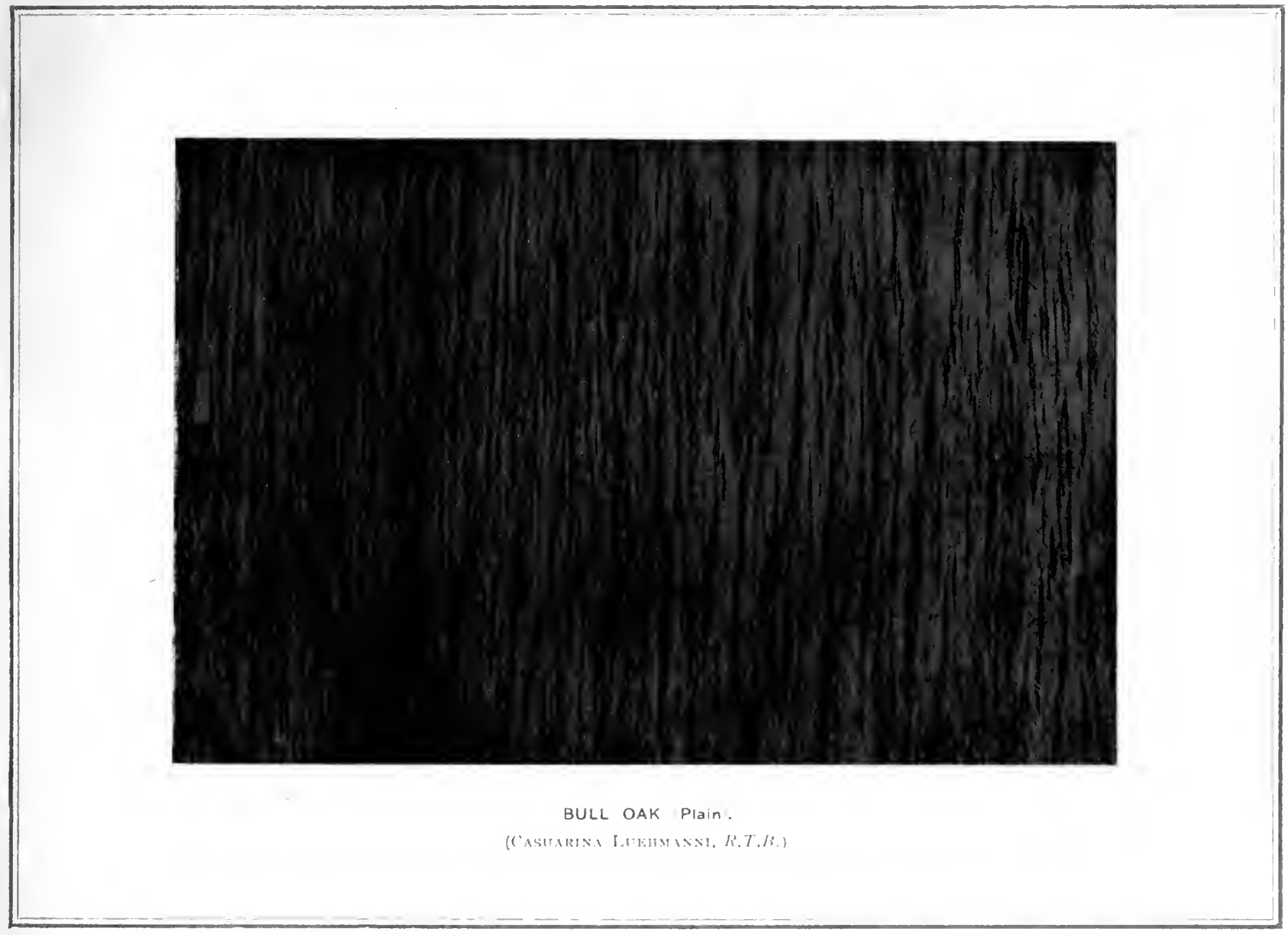




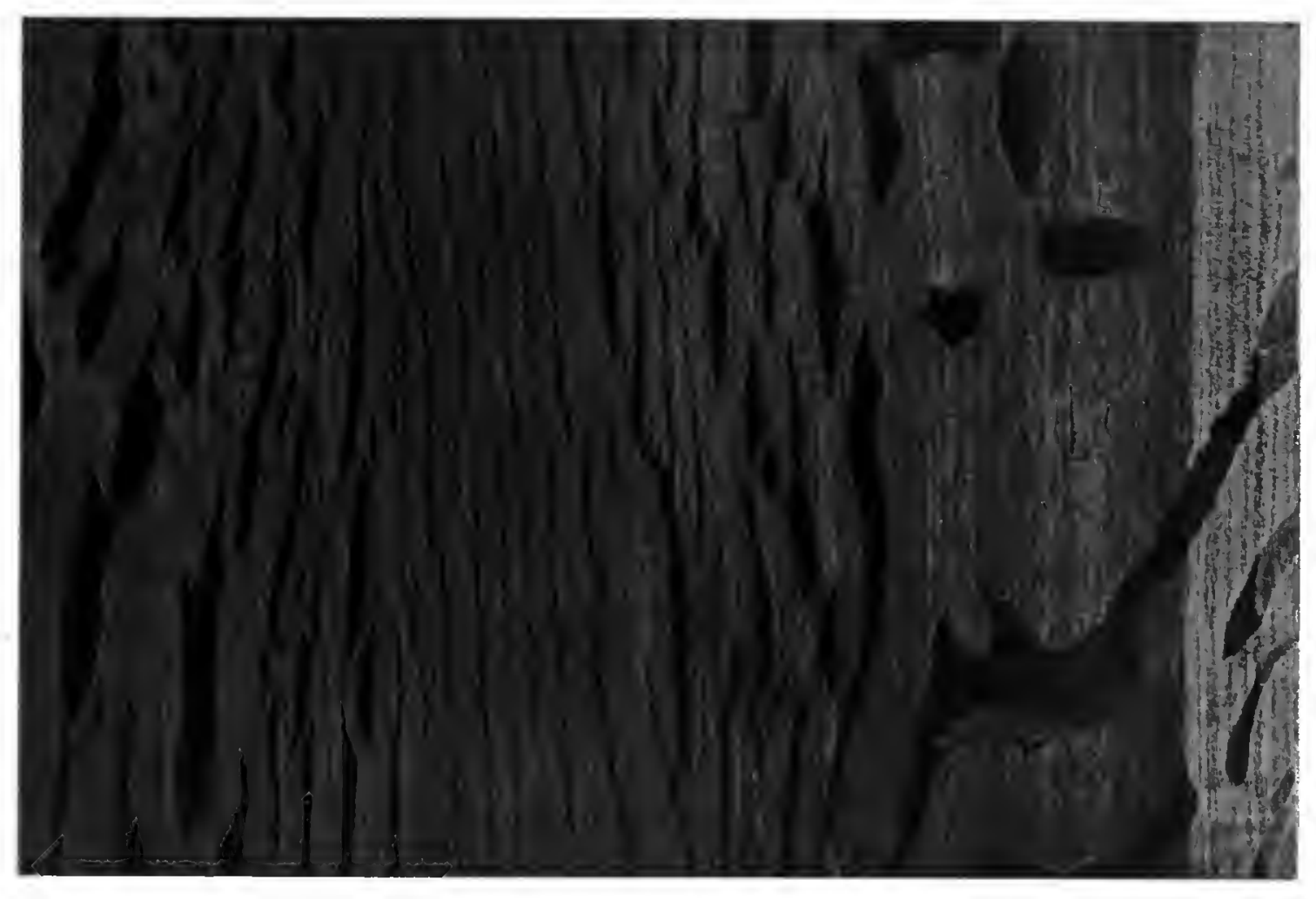

BULL OAK IF gUPEA 


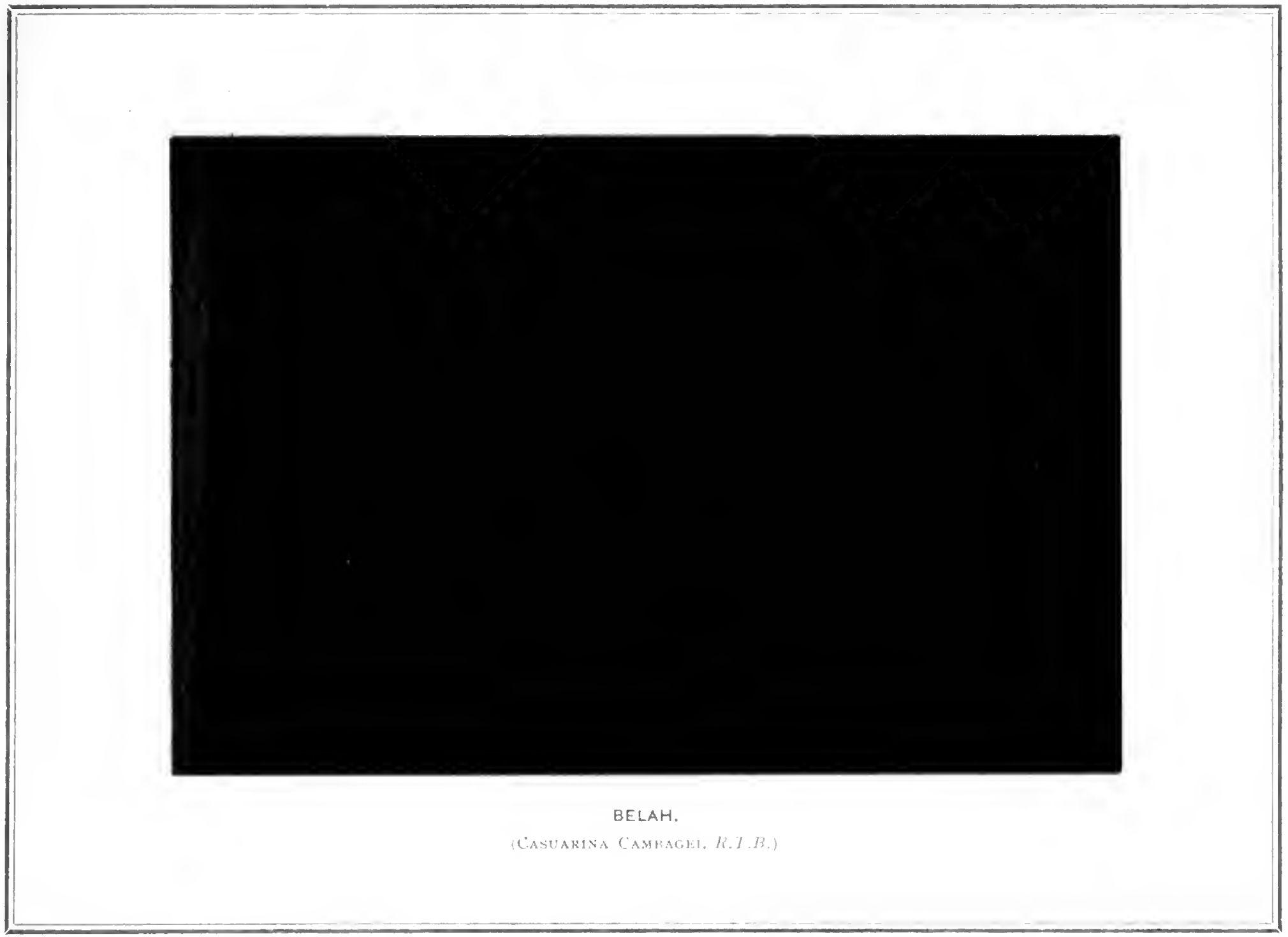




\section{Belah.}

\section{(Casuarina Cambagei, R. T. Baker.)}

The common name, which is of aboriginal origin, stands alone amongst its congeners, for the rest of the group of these trees have more descriptive local names, such as Bull Oak, She Oak, Forest Oak, \&c. It is now a well-known tree of the interior, and is differentiated without difficulty from its family, "Oaks," both in the field and herbarium, but more especially in a ligneous classification, for the timber is quite characteristic and has no resemblance to that of any of the other Casuarinas. The common name, Oak, has been applied to all the Australian Casuarinas except this one, a fact probably due to the nature of the timber, which is quite devoid of the Quercus feature of all the other woods of the genus. It is very dark in colour, hard, close grained, without a figure, and but for this latter defect might be classed as a "Walnut" coloured timber. It dresses to a hard, firm, even surface, takes a good polish, and could be used for several forms of cabinet work where solidity is a sine quâ non.

The coloured illustration is given in connection with this species to show the contrast between it and other Casuarina timbers, and it will be seen, there is nothing macroscopically to associate it with the timbers of other Casuarinas, the medullary rays being wanting; the colour is also quite exceptional; in fact, as shown by me before our local Linnean Society in I9I I, it may be regarded as the anomalous species of the genus. At a casual glance it might easily be mistaken for a Myall or Brigalow, from its colour and texture, although it has no aroma such as obtains in their case.

Description of the Tree.-A tree attaining a height of from 70 to 100 feet, dicecious, glabrous; branchlets glaucose or dark green in the slender form, ascending, internodes varying in length up to half an inch. not prominently angled. Whorls nine to ten, merous, the sheath teeth acute. Male spikes at the ends of the branchlets, in the slender variety from I to I $z$ inches long, in the glaucous variety usually I inch long, sheathing teeth erect. Cones cylindrical, about I 2 to I4 lines long, and Io to I2 broad, truncate, valves obtuse, very prominent, glabrous or minutely hoary, pubescent on the exposed dorsal half, with a dorsal prominence or thickening. Nuts pale coloured, 3 lines long, including samara. land.

Geographical Range.-Interior of South Australia, New South Wales, and Queens- 


\title{
The Red or Forest Oak.
}

\author{
(Casuarina torulosa, Ait.)
}

This tree is not difficult of identification either in the field or from the fruits-cones as they are sometimes called, for when once seen it can easily be differentiated from those of its congeners, the valves being less prominent than in other species, and the intervening ligneous substance being strongly rugose. The timber is also distinct, being of a uniform warm, red colour throughout. The rays are well marked, producing the usual "Oak figure" of the genus. It is hard, close grained, yet fissile, polishes into a warm rich colour, and could be utilised in many ways in fancy cabinet work, but not in large slabs, as the tree is at its full size 50 feet high, and $r 8$ inches in diameter. Like the rest of the species, it requires to be sawn methodically as soon as felled, and stacked for seasoning, for if not it splits in a very uneven manner, and so much timber is wasted. It is very suitable for balusters or any kind of small turnery, being very strong. Specimens exhibited at the Christchurch Exhibition were much noticed.

Description of the Tree.-A rather small tree growing away from water, with a fairly rough bark. Branchlets very slender, in fact, more so than perhaps any other species. Leaves generally four, adnate, the slender branchlets giving a ribbed appearance. Male spikes very slender, $\frac{1}{2}$ to i inch long. Cones very shortly cylindrical or approaching globular shape, about $\frac{3}{4}$ inch in diameter and long, the dorsal appendages of the woody valves covered with numerous small tubercles. Queensland.

Geographical Range.-Coastal ranges and districts of New South Wales and 


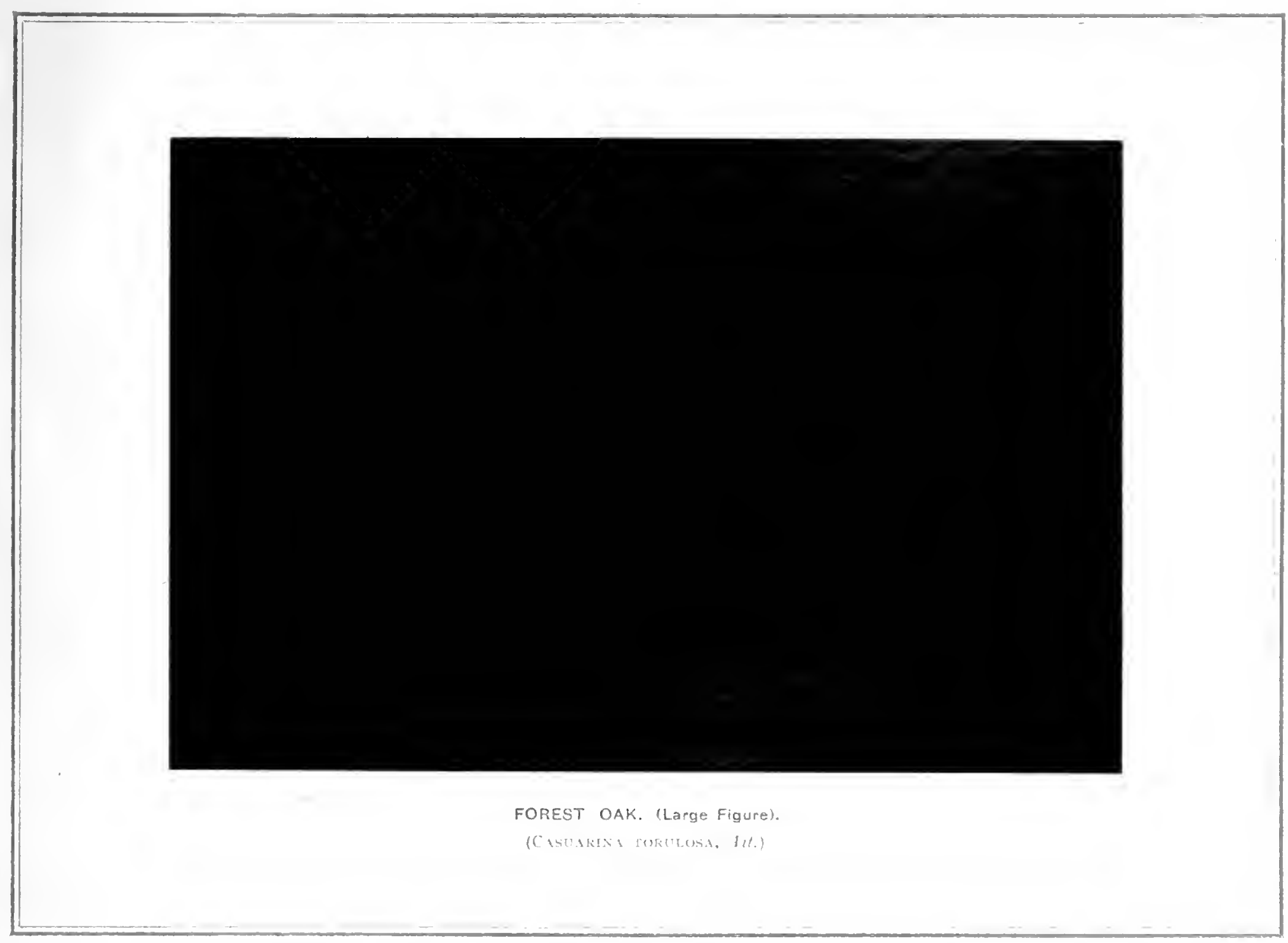


NATURAL ORDER

\section{CUPULIFER $Æ$. \\ 舫}

THESE trees are famous the world over for their valuable timbers, which are more commonly known as Oaks, Hornbeams, and Beeches. The two former do not occur here, for what are known as Oaks belong to quite a different Natural Order, viz., the Casnarineæ. There are, however, three true Beeches here, but only two suitable for our purpose, viz., Negro Head Beech of New Sonth Wales, and Iyrtle of Tasmania. The latter is by far the better timber for cabinet work, as it is light in weight, reddish in colour, and seasons well; the New South Wales tree is rather a refractory one as regards seasoning. They are both fine upstanding, tall trees, and probably taller than their congeners of the Northern hemisphere.

Species Illustrated in Colour :-

Rəd Myrtle or Beech (Fagus Cunninghamii, Hooker). 


\section{Red Myrtle or Beech.}

(Fagus Cunninghamii, Hooker.)

In the matter of Beeches, Tasmania shares with the mainland the privilege of having one true species, and in this case a superior one, for it seasons much quicker and better than Fagus Moorei of New South Wales. The wood could not be confounded with the European Beech, as the colour is quite different, being a brick red or terra cotta, and neither is the figure so distinct as characterises the European species. It is a soft, yet close-grained, easy working timber, light in weight, and polishes well, and could be used for doors and sashes of show cases. It has been used in constructing one of the large show cases in this Museum, and is giving much satisfaction, and for other reasons could be classed as a really first-class joinery and cabinet timber, and is an excellent carring wood.

Description of the Tree.-This is a true Beech, and is one of the largest trees found in Tasmania, attaining sometimes a height of over Ioo feet and a diameter up to 4 feet, with a very dense foliage. Leaves evergreen, very shortly petiolate, broadly ovate, deltoid. rhomboid or orbicular. flat or slightly convex, coriaceous, $\frac{1}{4}$ to I inch long. Flowers monocious. Male flowers solitary and pedicellate in the lower axils of small axillary branchlets. Perianth six lobed, very small. Female involucre, sessile in the upper axils, containing each three flowers. Perianth limb of three small teeth on the angles of the ovary. Fruit ahout 1 inch long, consisting of one or more nuts placed upon, or more or less enclosed in the ustally enlarged persistent involucre. Nuts two, with three wings, and a central flat one with two wings.

Geographical Range.-Ranges of Victoria and Tasmania. 


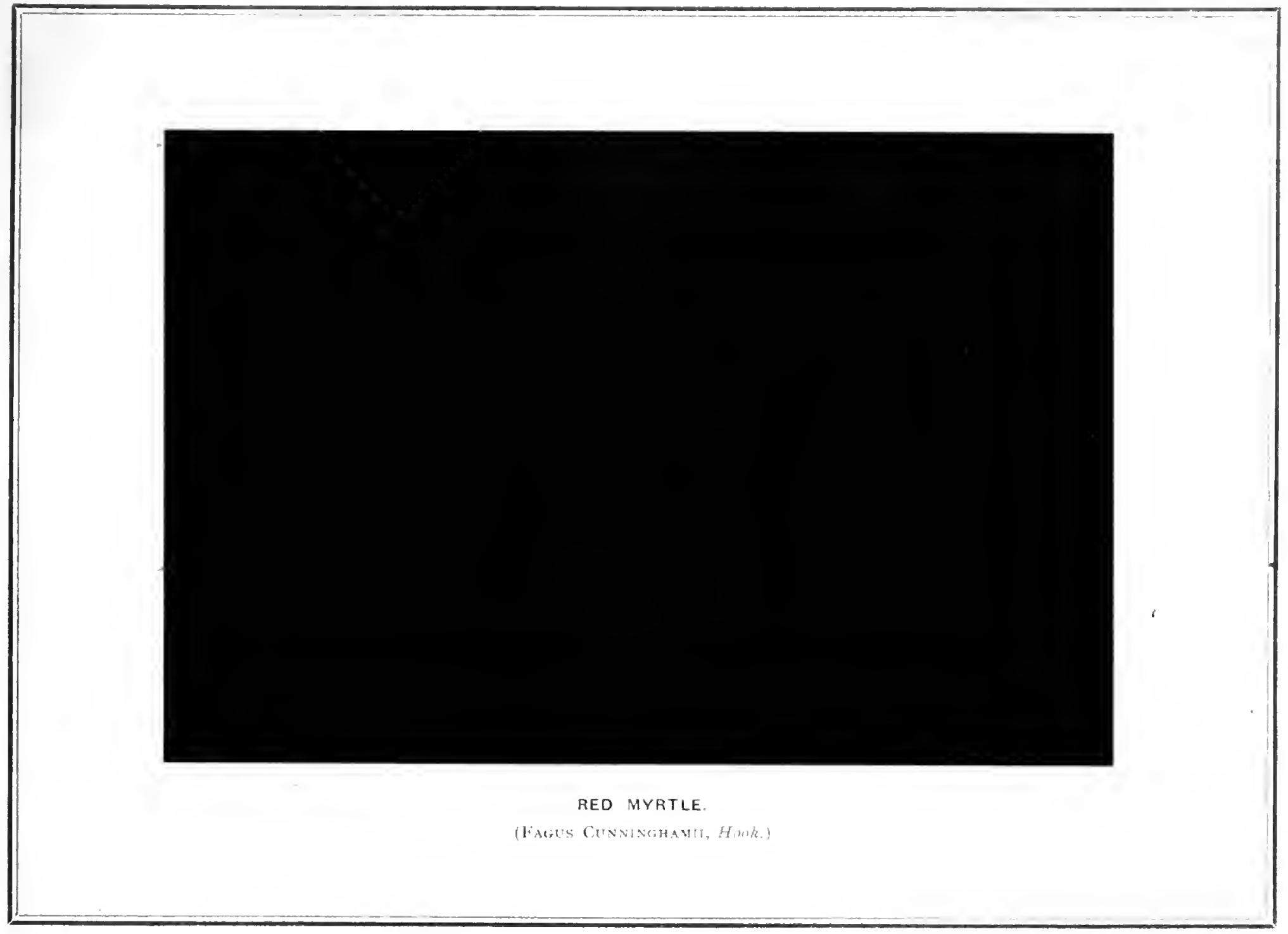



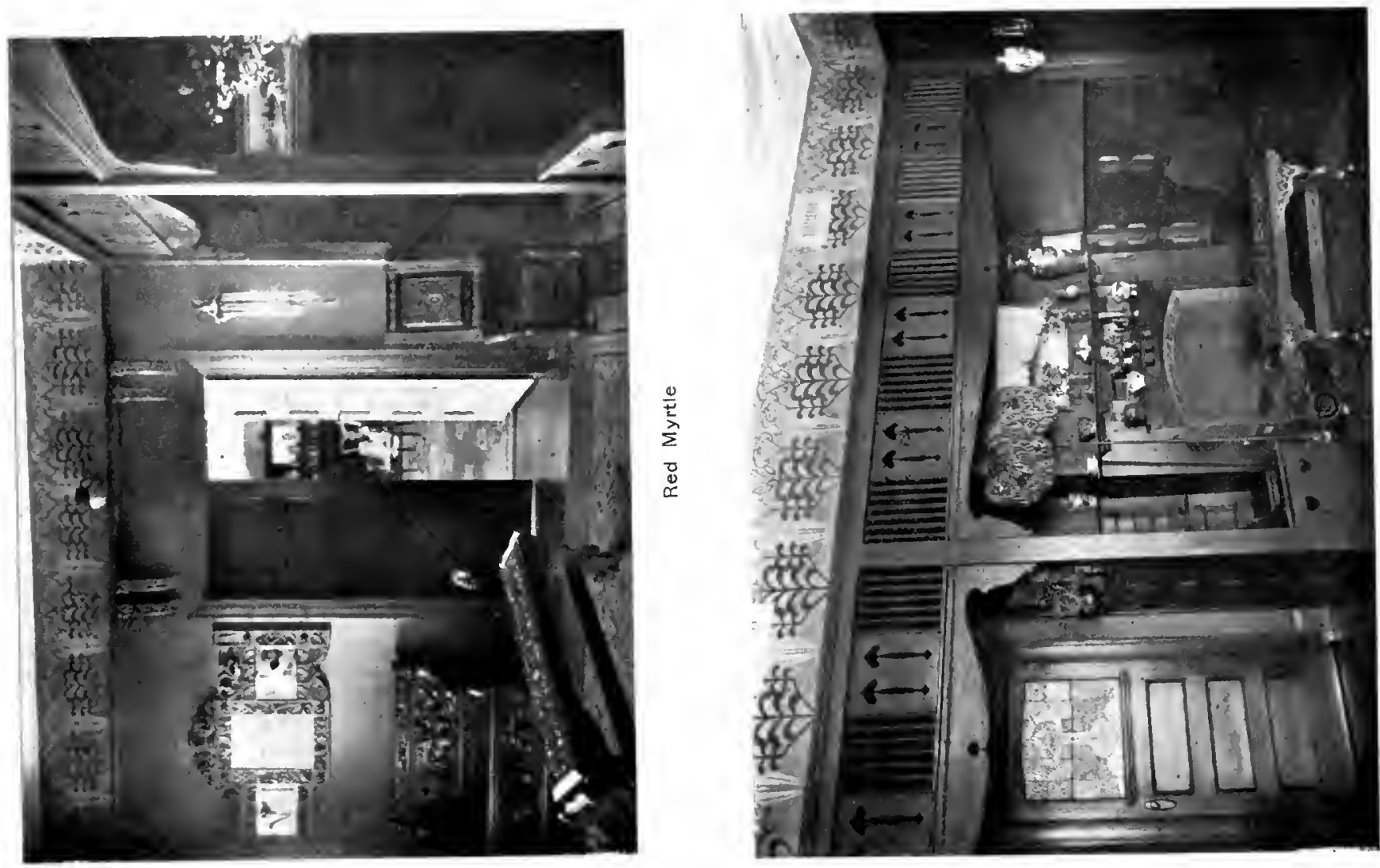

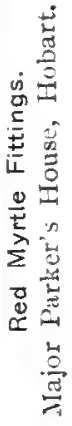




\section{SANTALACE $Æ$. \\ $x \%$}

A FAIRLY well distributed Order over the world, and famous more particularly as yielding the Sandalwocd of the East. There are one or two species in Australia that call for remark in this work, and one produces the Sandalwood of Western Australia, although the tree occurs throughout most of the States, but is only exported from the IVest. Most of the other representatives of the Order in Australia are small shrubs, but there is one exception that might be mentioned, namely, the Native Cherry (Exocarpus cupressiformis). The figure of this wood is small, but pretty, and looks well when used to aid decoration in cabinet work.

Species Illustrated in Colour:-

Exocarpus cupressiformis, Labill. 


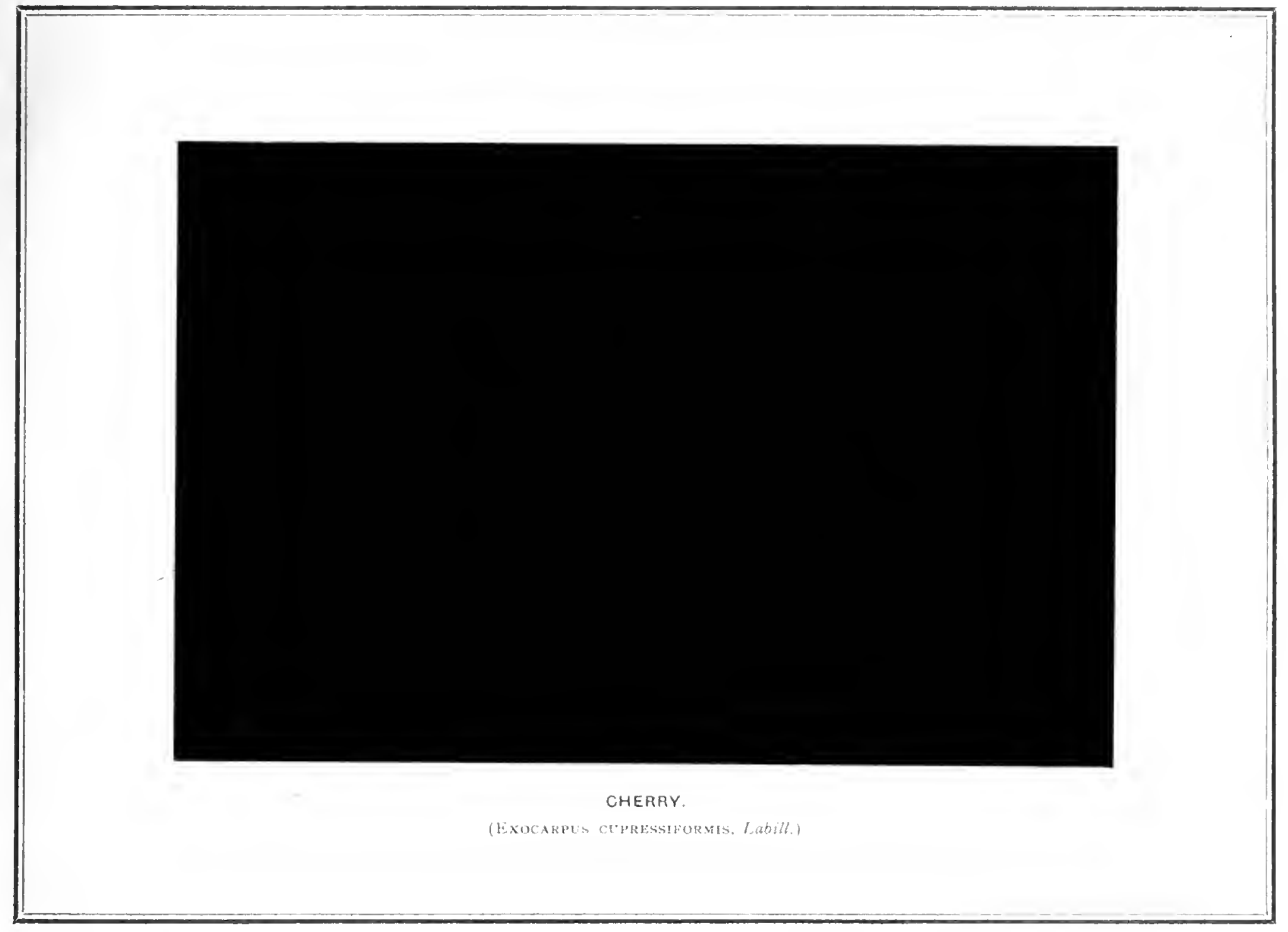




\section{,}

$\ldots$ 


\section{Cherry Tree.}

(Exocarpus cupressiformis, Labill.)

A list of our cabinet timbers would, perhaps, not be complete without the inclusion of this timber, although it is rarely seen on the Sydney market. The tree sometimes attains a diameter of 18 inches, and a height of $5^{\circ}$ feet, so that some large specimens could be obtained for cabinet work. It is a close-grained, lightish red coloured, fairly heavy timber, having a very neat little figure; polishes well and dresses easy.

Description of the Tree.-Only occasionally does this tree attain a height of orer 50 feet. It is quite gregarious, that is, will only grow in company with other bush trees. The bark is rough, regularly ridged, and divided into sections. Leaves reduced to minute alternate scales. Flowers minute in little terminal or lateral, very shortly pedunculate spikes, up to $\frac{1}{4}$ inch long. Perianth segments five, very small. Fruit a drupe or nut, ovoid or globular, resting on the enlarged succulent red pedicel, about $\frac{1}{4}$ inch in diameter, and known as Native Cherry.

Geographical Range.- Throughout the Commonwealtli. 


\section{CONIFER E.}

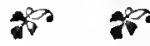

Australia possesses a valuable asset in its timbers of this world-wide Order. Taking first the most extensively distributed genus of the Order-Callitris, one finds in it a timber of high decorative character. These timbers are used extensively in building construction in the districts where it is plentiful, and when polished or varnished the dark heartwood with its figure adds considerably to the attractiveness of the home. They also make beautiful columns, and could be used to decorate artistic furniture. The Brown Pine, Queensland Kauri, King IVilliam Pine, Huon Pine, and Celery-top Pine are all valuable cabinet timbers.

\section{Species Illustrated in Colour :-}

White Pine (Callitris glanca, R.Br.).

Black Pine (C. calcarata, R.Br.).

King William Pine (Athrotaxis selaginoides, Don).

Hoop Pine (Arancaria Cunninghamii, Ait.).

Bunya Bunya (A. Bidzrilli, Hook.).
Queensland Kauri (Agathis robustu, C. Moore). Huon Pine (Dacrydium Franklini, Hooker). Celery-top Pine (Plyyllocladus rhomboidalis, Rich.). Brown Pine (Podocarpus elata, R.Br.). 


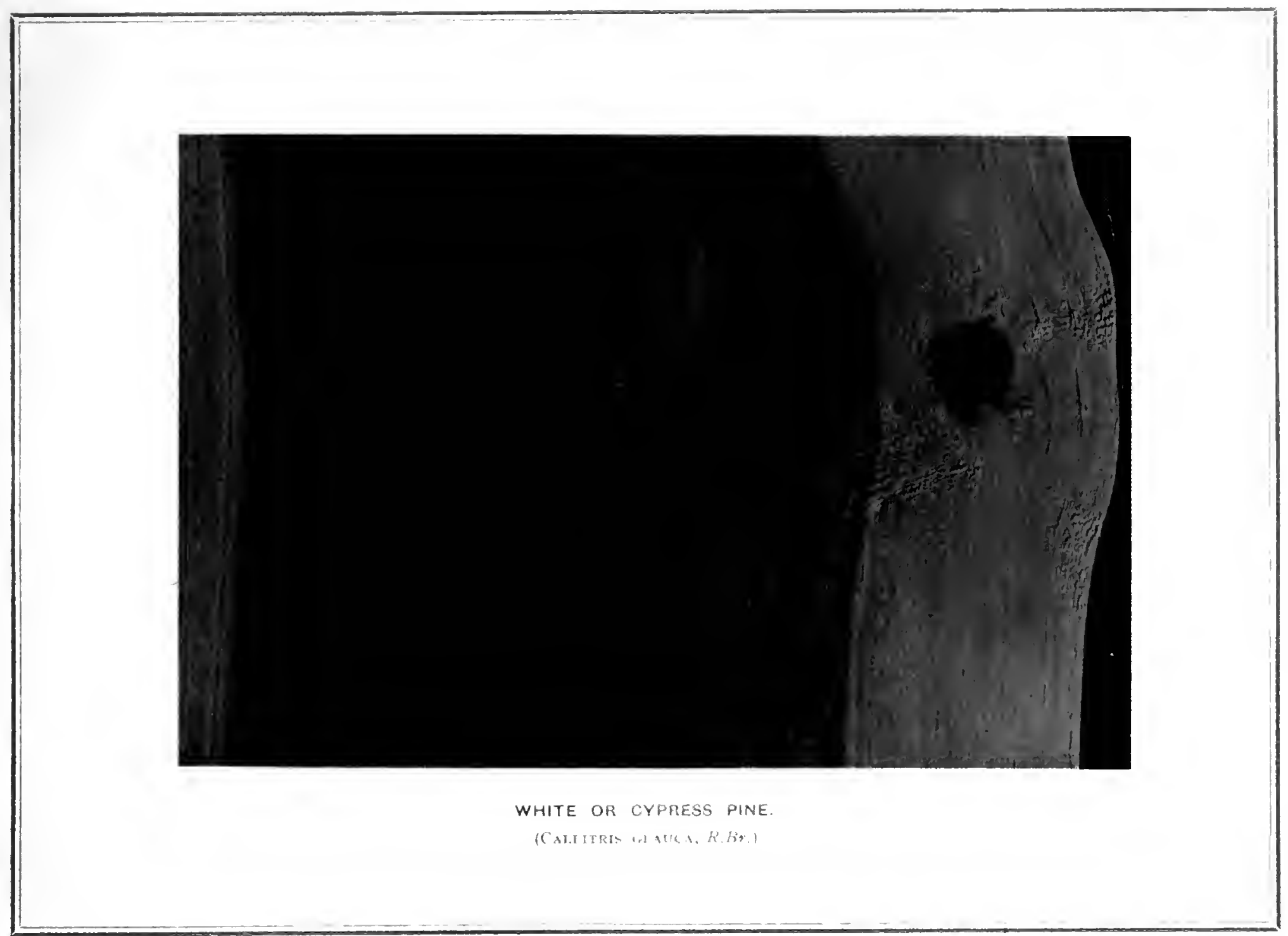




\section{White or Cypress Pine.}

(Callitris glauca, R.Br.)

The common name appears pretty general throughout its distribution, and is used to distinguish it from its congener, C. calcarata, R.Br., which occurs in the ridges or hills contiguous to the plains where $C$. glauca is found. It attains its maximum height on the eastern and southern portions of its distribution, and gradually diminishes in stature as it spreads towards the interior of the Continent.

It is an aromatic timber, due to the presence of Phenol, but this is no deterrent to its seasoning, which gives little trouble. It is what might be called a fissile timber. It is eminently suited for panelling; its dark colour and wavy figure often gives it a beautiful character. Turned into columns for vestibules, it is probably unsurpassed for beauty amongst Australian timbers for this special purpose. Several such columns are on view at the Technological Museum, and some were exhibited at the Franco-British Exhibition in London in Igog, and were much admired.

The Callitris as a group present a variety of timbers amongst its species, and this particular species has in itself also a variety of woods of various shades. Sometimes it is quite pale, being almost white; whilst more commonly it is from a light to a dark chocolate colour, when it is much preferred for interior wall decoration of houses in the far West, and looks particularly well when polished or varnished. It also makes handsome picture frames, mouldings, and skirtings, and would look well in panelling, but is not recommended for chairs or tables. 
It is a close-grained timber, light in weight, short in the grain, and splits so readily that it is necessary to bore holes before using nails. The numerous knots rather add to its beauty as a decorative timber. Having such a great variety of colour and grain, a very artistic effect could be secured in cabinet work by a careful selection of the timber.

Description of the Tree.-An evergreen tree, varying in lieight according to environment. In the far interior it is stunted in growth, whilst towards the main Dividing Ranges it attains a height of over Ioo feet, with a diameter from 2 to 3 feet. The bark is hard, compact, furrowed, but lighter in colour than that of $C$. calcarata, which forms with it the principal pines of the interior.

Leaves are at first pyramidal, then decurrent in whorls of three, glaucous, the internodes being shorter than obtain in most species; free end short, acute, the decurrent portion rounded.

Male amenta small, 2 to 4 lines long, cylindrical, oblong, or ovoid, very numerous, occurring in general, in threes at the end of the leaf series, the stamens in whorls of threes, the scale-like apex concave, cordate, anther cells two to four. Female amenta solitary or not often found in clusters, situated generally at the lower part of the branclilets.

Fruiting cones globular, rarely pointed at the top, about half an incli, exceptionally three-quarters of an inch in diameter, slightly scabrous, valves six, alternately large and small, the latter about a quarter less in size than the larger ones, valvate, channelled at the base, dorsal point scarcely perceptible. Seeds two to three-winged; the central columella under 2 lines.

Geographical Range.-No Callitris has so wide a distribution as C. glanca. It occurs on the western slopes of the coastal ranges of the continent, right across the far interior from east to west and north to south. It is easily distinguishable from its congeners by its glaucous foliage.

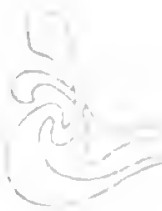


BLACK OR CYPRESS PINE.

(Callttris (ankarata, li, $h$ r.) 


\title{
Black Pine, Red or Mountain Pine.
}

\author{
(Callitris calcarata, R.Br.)
}

This timber has sometimes a duramen almost as dark as that of C. intratropica, the darkest of all Callitris, but with a far more ornamental figure, and so is in much request for inside boards, for lining houses, wainscotting, panelling, \&c.

The timber, however, is seen to best advantage along with other and quieter-looking woods, for when used alone the figure is perhaps too pronounced.

For general purposes, such as those in which our eastern coast pine timbers are employed, it is not recommended, being too short in the grain, and too thickly studded with knots. But in the interior districts it is invaluable, being used for building, fencing, post and rails-lasting in the ground, according to some correspondents, twenty-five years or more. Others say it is not so durable.

For turning into columns or pedestals for halls and statuary it is particularly well adapted, the numerous knots and wavy "flower" producing a very effective natural decoration. It takes a high polish. 
Like its congener ( $C$. glauca) it has a reputation for immunity from termites, and on this account is highly valued for house-building in the interior of the country.

It often contains a good quantity of guaiol, which crystallises out on the surface of the freshly-cut timber.

Description of the Tree.-An evergreen tree attaining a height of 60 to 80 feet, with a dark, hard, compact, deeply furrowed bark. The leaves are not glaucous, and occur in whorls of threes, decurrent, sharply convex on the back, free end obtuse or acute with almost scarious edges; in the very young plants the internorles are very short and the ridges flattened. Nale amentum mostly solitary and axillary, and when terminal in twos and threes, $\mathrm{I} \frac{1}{2}$ lines long, compact, rather paler in colour than those of other species. Anthers two or three, rarely four. Female amentum as in other species.

The cones are in chusters or solitary, smooth, sometimes rugose, globose, or oval, obtuse, 9 lines long and about 6 lines in diameter, the three larger valves being slightly dilated upwards; the dorsal point not far removed from the apex of the valves; valves valvate before opening, but the edges rounded afterwards, central columella short, with three narrow sides. Seeds black, wings varying in size up to 6 lines.

Geographical Range.-As one of the common names would suggest, this pine has a preference for high ground, but it is not solely restricted to elevations. It is, however, from its occurrence in such situations that has given rise to the term "Pine Ridge," so frequently found on our maps. It is fairly well distributed on the Eastern States of the Commonwealth. 


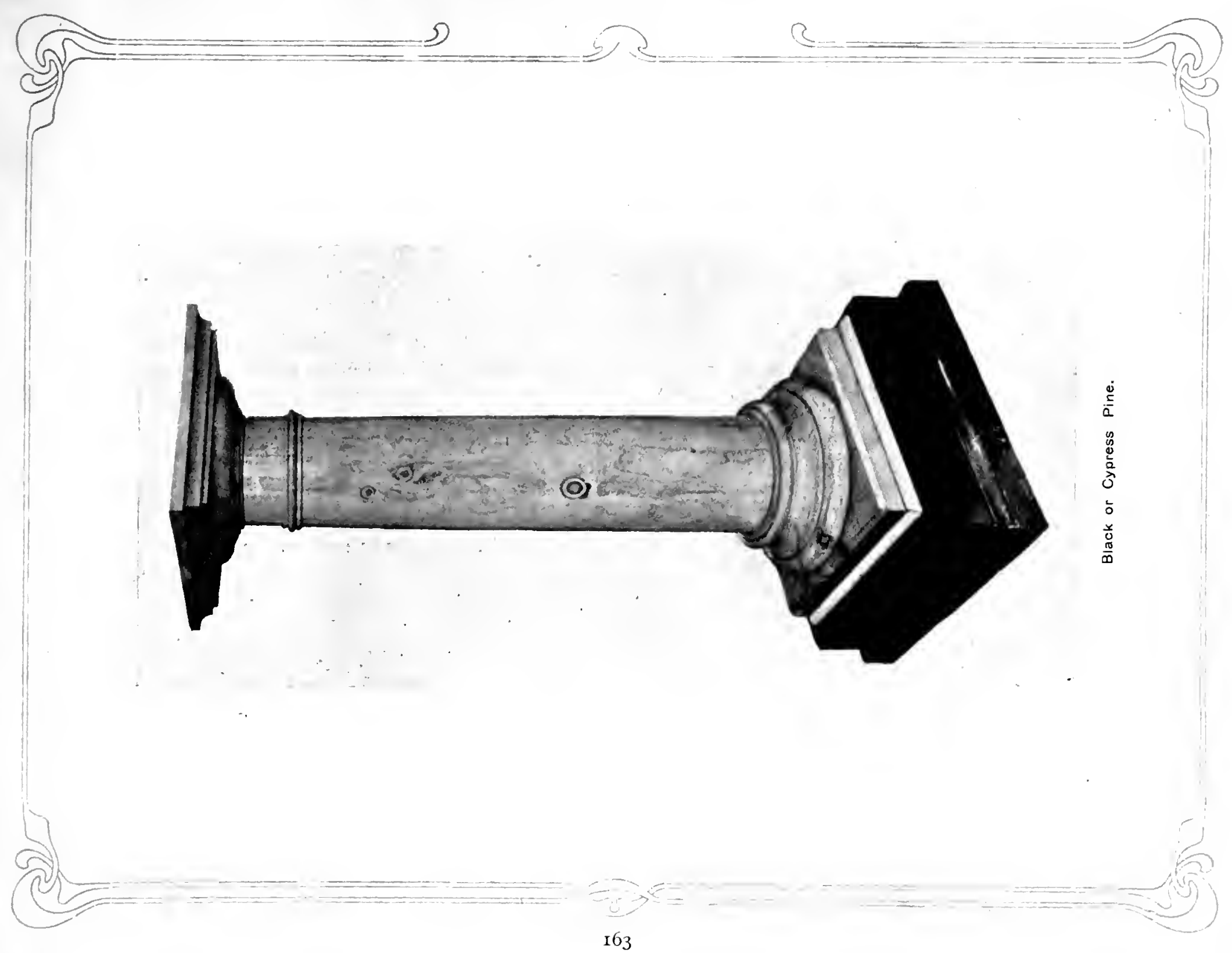




\title{
King William Pine.
}

\author{
(Athrotaxis selaginoides, Don.)
}

This is one of Tasmania's finest softwood timbers. It has hardly the usual pale colour of the Pines, having a pinkish tint, but is, nevertheless, a beautiful timber, being easy to work, light in weight, very evenly grained, the autumnal rings contrasting with the vernal ones and producing a soft, pleasing effect. It planes well and easy, takes a good polish, and is eminently suited for violins, and for various forms of cabinet work requiring lighter shades of colour. It is very similar to Californian Redwood (Sequoia sempervivens), and, like it, very suitable for mouldings, skirtings, or any kind of joinery work not requiring strength, and in addition has a great reputation for durability.

Description of the Tree.-Leaves small, homomorphic, decussate or in close spires, appressed or spreading. Male amentum terminal, catkin-like; microsporophylls spirally arranged, imbricate, shortly attached, scale or leaf-like expansion, oblong, sagittate and peltate, bearing two-celled sporangia; the pollen cells are globose or three-sided, with two or three bands. Female amentum is composed of spirally arranged imbricate macrosporophylls, bearing from three to six pendulous ovules.

Fruit cones terminal, sessile, small, globular, composed of woody scales wedgeshaped at the base, thickened upwards, dilated at the apex, below which is a dorsal point. Seeds few under each scale, ovate, compressed, with a transverse hilum and two longitudinal wings, the integument being crustaceous. The cotyledons number two.

This is a larger tree than either of its congeners, and has loosely spreading slightly imbricate leaves, measuring about 4 lines long. Cones about $\frac{3}{4}$ inch in diameter.

Geographical Range.-Tasmania. 
11

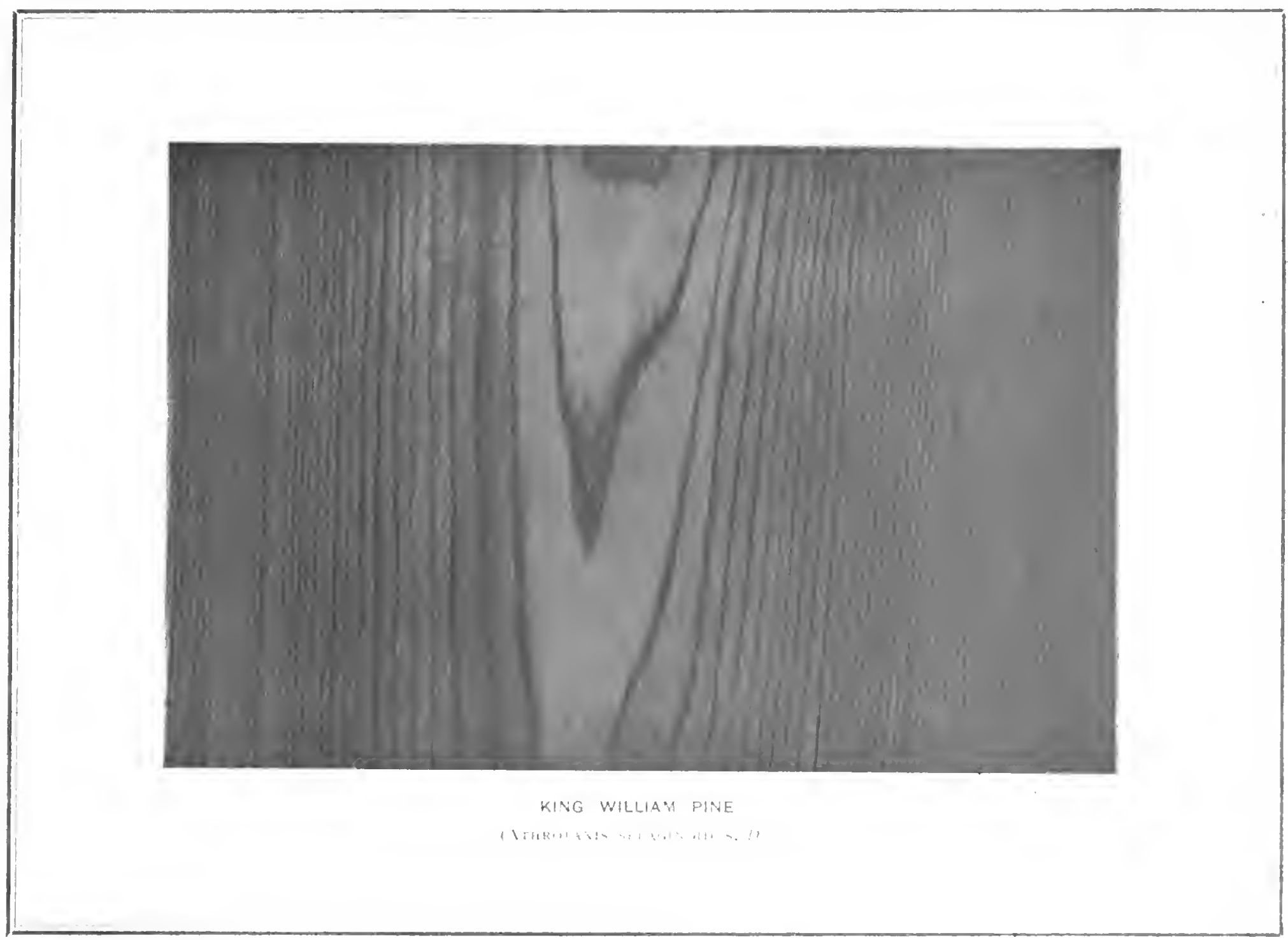




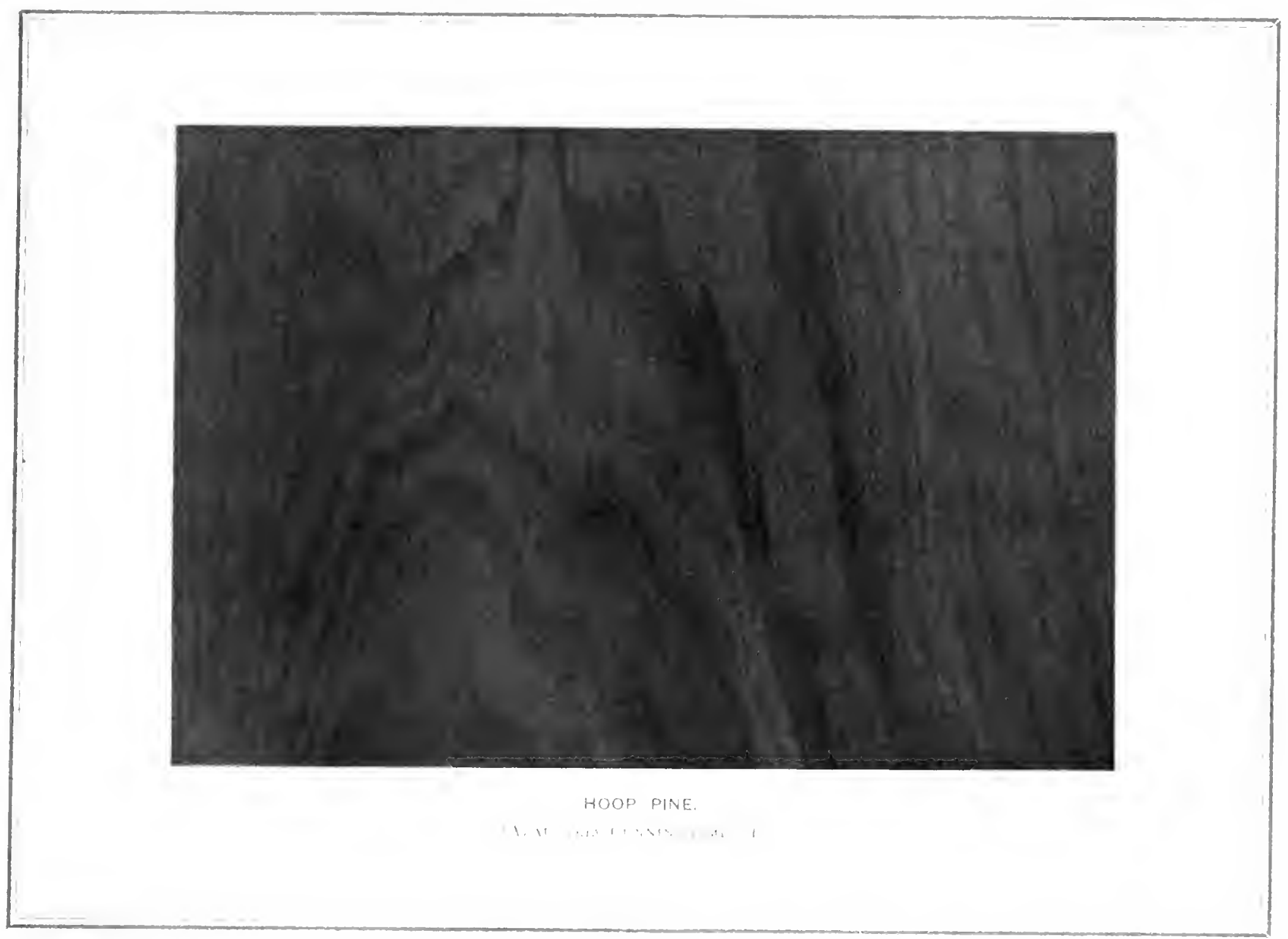




\title{
Hoop Pine.
}

\author{
(Arancaria Cuminghamii, Ait.)
}

This Conifer is one of the giants of these scrubs, and some millions of feet have been drawn from these primeval forests since the occupation of this continent by the white man, being one of the few pale, soft timbers of this country. It is light in weight and colour, free working, possesses all the characteristics of a Pine timber, and is used extensively for flooring, linings, mouldings, skirtings, doors, and joinery generally, in addition to all the cheaper kinds of cabinet work. It can also be used for panelling in railway carriages. Decays quickly on exposure to dampness.

Description of the Tree.-This is one of the largest of Australian Pines, attaining sometimes a height of 200 feet. The bark is characteristic, having the appearance of horizontal bands (hence the name Hoop Pine), and is hard, compact, and permeated with oleo-resin cells. Leaves are dimorphic, being crowded, spirally arranged, imbricate, incurved, 3 to 4 lines long, ribbed, pungent, pointed, in one case, and on the lower branches spreading, straight, vertical, decurrent, and sometimes over an incl long. Male amentum sessile, cylindrical, compact, 2 to 3 inches long, about 4 lines in diameter; the scale-like apices of the stamens are ovate-rhomboidal and acute.

Fruit cones ovoid, about 4 inches long and 3 inches in diameter, the scales broadly cuneate, the original sporophyll apex developing into a recurved, rigid, acute point.

Geographical Range.-Confined to the scrubs of the North Coast districts of New South Wales and Southern Queensland. 


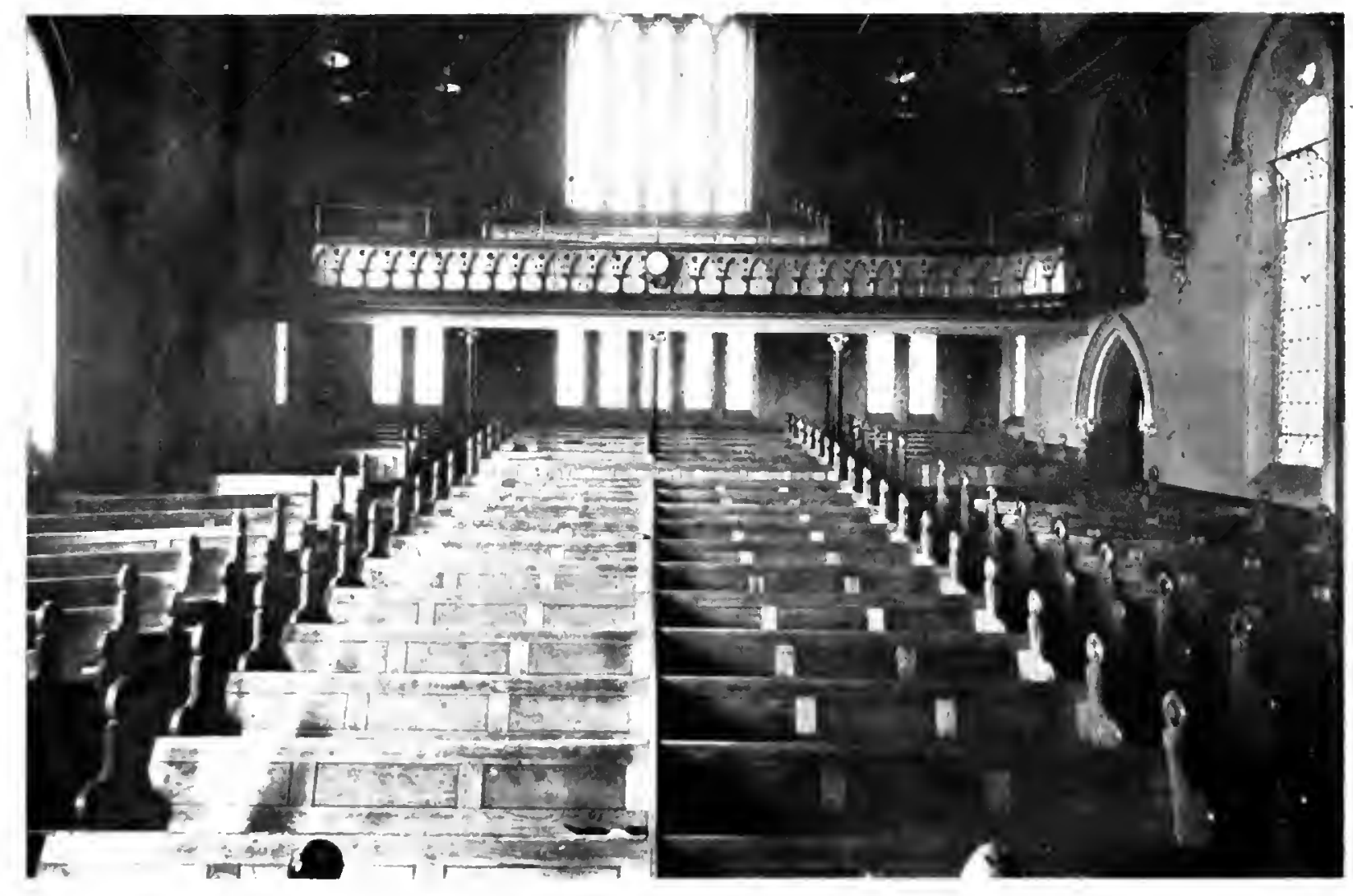

Hoop or Colonial Pine Pews.

Presbyterian Church, Glebe, Sydney. 


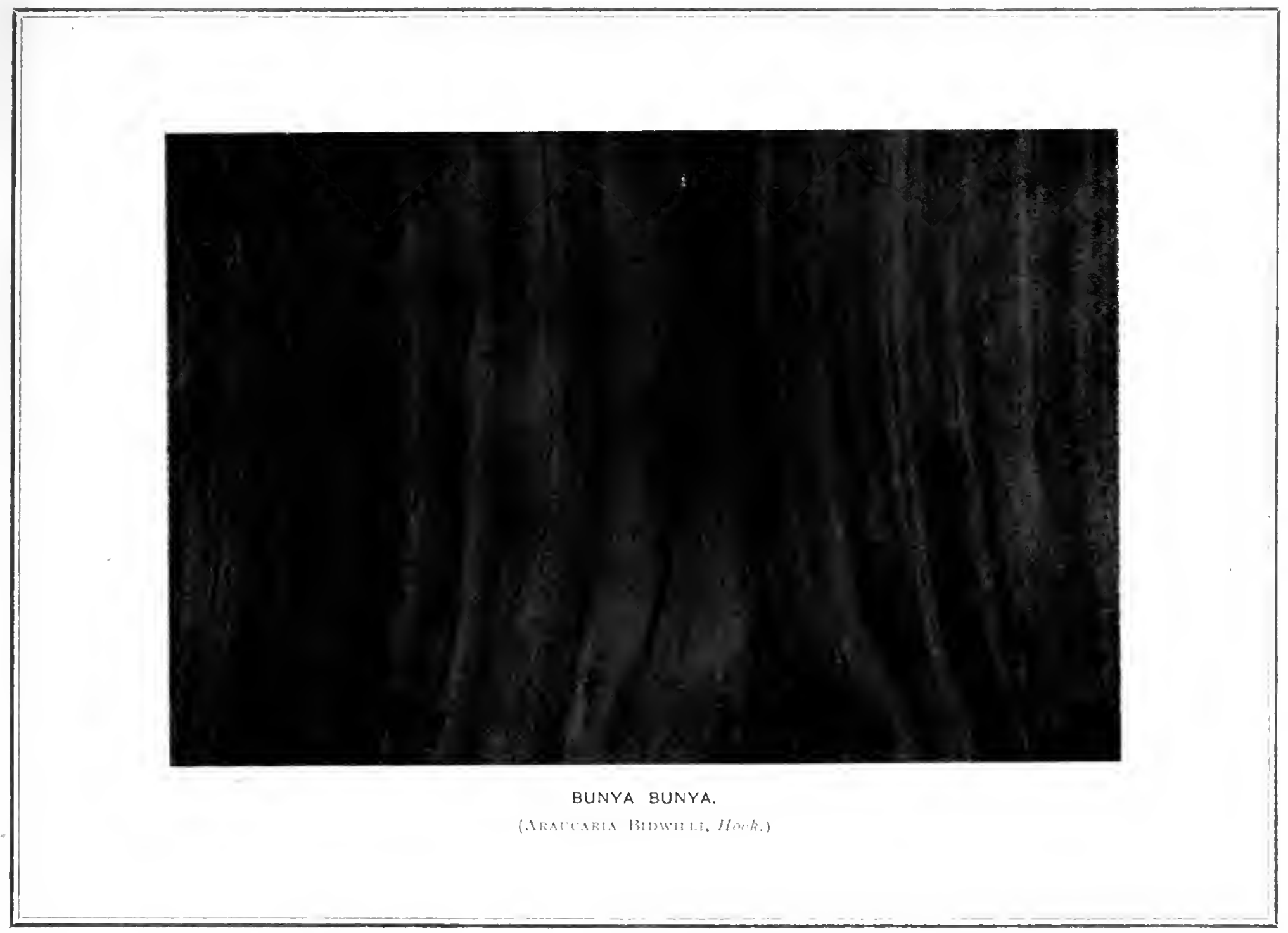




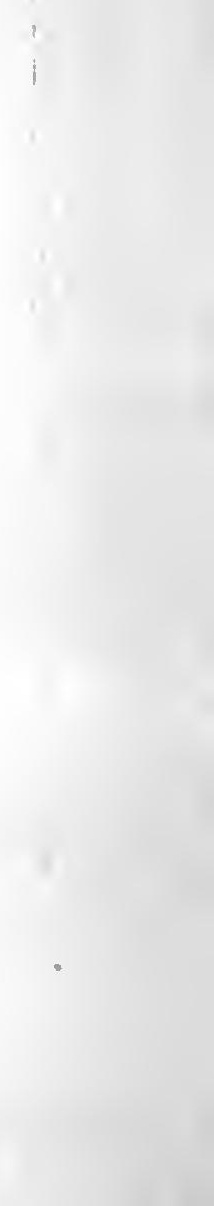




\title{
Bunya Bunya Pine.
}

\author{
(Arancaria Bidwilli, Hook.)
}

Irr this species of Araucaria, Queensland has one of its principal sources of supply of soft timbers. It is very pale, even grained, easily worked, and useful wherever a pale indoor timber is required.

Description of the Tree.-This is a beautiful forest tree attaining over $I_{5} 0$ feet in height, and now much cultivated for its symmetrical shape and the remarkable appearance of its whorled branches, with their spirally arranged leaves, which give it a facies more nearly approaching the South American A. imbricata than its Queensland congener, A. Cunninghamii. It is, however, a very much quicker grower than the South American Pine.

The leaves are numerous, homomorphic, imbricate, spirally arranged, lanceolate to ovate-lanceolate, sessile, under 2 inches long, shining, and broad at the base, milrib not more developed than the numerous lateral veins, very sharply pointed. Nate amentum is sessile, arranged in closely and spirally packed catkins towards the end of the branches, sometimes over 6 inches long, and $\frac{1}{2}$ inch in diameter, the imbricate scale-like apices of the stamens four-sided.

Fruit cones on the higher branches, ovoid, globose up to 12 inches high, and 9 inches in diameter; the scales imbricate, 4 inches long and 3 inches broad, tapering towards their winged base, the point of the sporophyll recurved and spinescent. A cone Io $\mathrm{lb}$. in weight was obtained from a tree, having also male catkins.

Geographical Range.-Coastal ranges of Queensland. 


\section{Queensland Kauri or Dundathu Pine.}

(Agathis [Dammara] robusta, C. Moore.)

The occurrence of a true Kauri timber in Australia is perhaps of more commercial importance than scientific. It adds another soft wood to our all too short list, and demonstrates that if such will grow here under natural conditions, they will flourish all the better under cultivation. The timber of this Kauri is rather more attractive than the New Zealand of the same genus. It is a shade darker in colour, being pale brownish; dresses easily, takes a good polish, and is suitable for table tops, furniture, or anything in the cabinet trade, also for mouldings, architraves, skirtings, and the cheaper kinds of furniture.

Description of the Tree.-This is a fine, tall, upstanding tree, attaining a height of I5o feet and over, generally with a long straight barrel free from branches. Leaves more often ovate than lanceolate, thick, from 4 to 6 inches long, and up to I inch wide, mostly obtuse, shortly petiolate, midrib not prominent, finely striated longitudinally from secondary bundles. Nale amentum catkin-like, axillary or lateral, surrounded by a few imbricate scales at the base, under 2 inches long. Fruit cones ovoid-globular, under 5 inches long, and rather less than 4 inches in diameter; macrophylls as broad as long, closely imbricate, deciduous, flattened, broadly cuneate, more or less winged. Seeds oblong-cuneate, flattened or emarginate, at the end one margin produced into a horizontal, erect, or decurrent wing.

Geographical Range.-Coastal ranges of Queensland. 


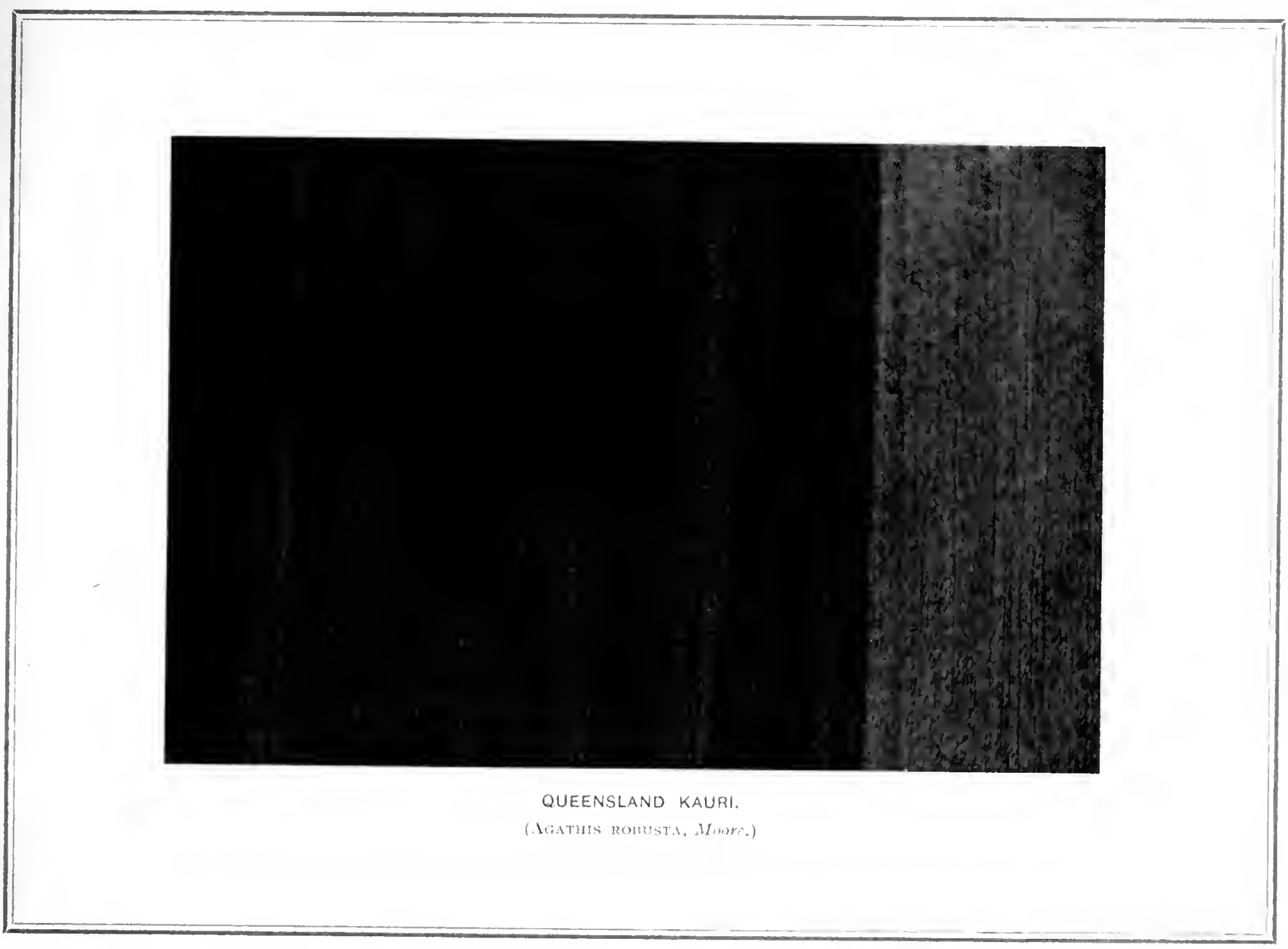




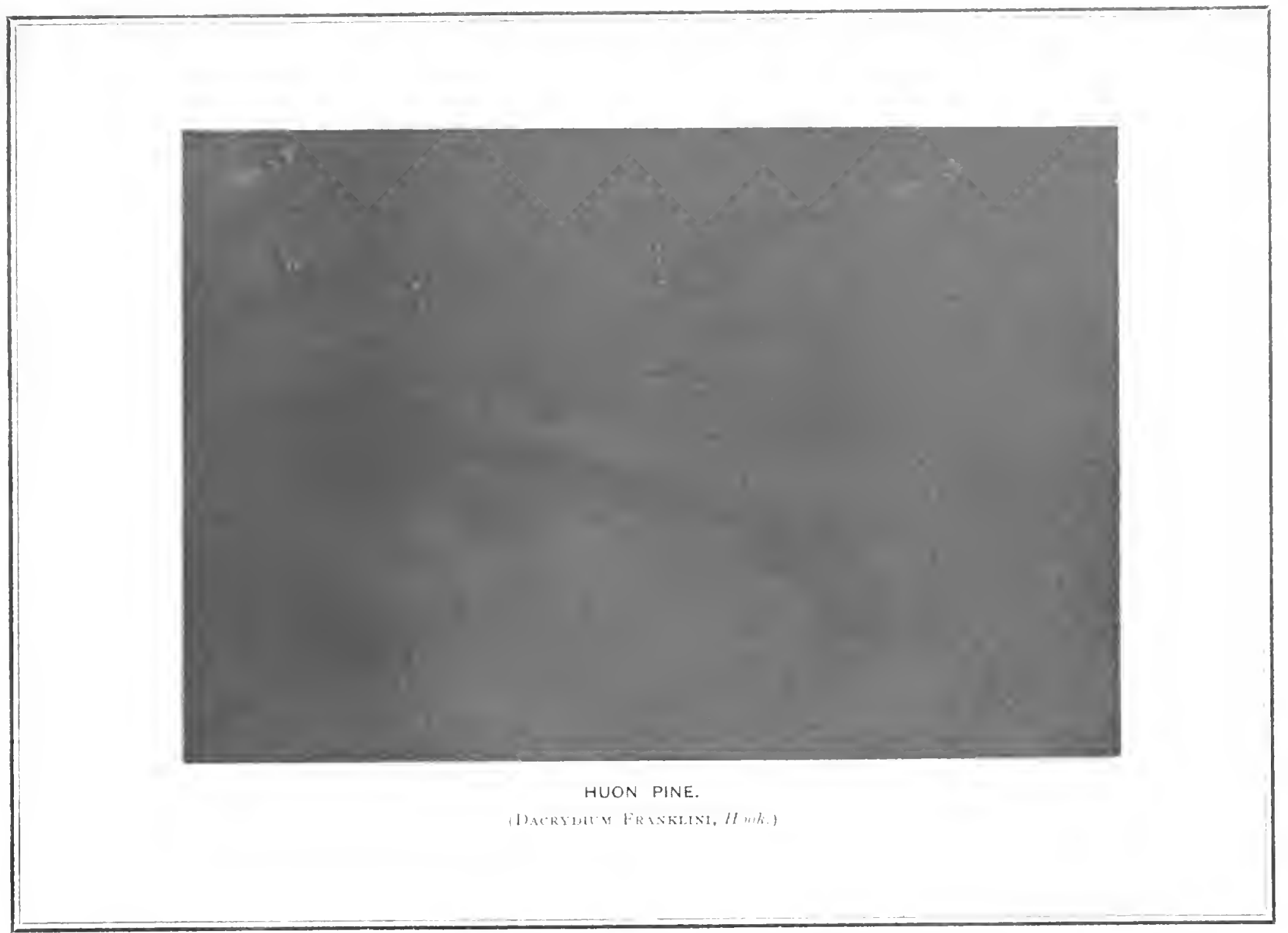




\section{Huon Pine.}

\section{(Dacrydium Franklini, Hooker.)}

Too much praise can hardly be given to this representative of the Coniferæ family for its good qualities, and it is justly appreciated by the trade, for it is one of the finest soft-wood timbers grown in Australia. For a Conifer timber it is close grained, light in weight, with scarcely any figure, but having a pale canary colour, which considerably adds to its value as a decorative timber. It dresses and polishes well, and could be used for panelling, or any kind of joinery or cabinet work, and is one of the best softwoods in the market at the present day. An essential oil has been obtained from this timber, which is fully described in "Pines of Australia," Baker and Smith, p. 404 .

Description of the Tree.-This tree is one of the best known in Tasmania, and yields one of its finest Pine timbers. It attains a height sometimes of over roo feet.

Leaves small, acute, and spreading on the young plant, in the mature plant closely appressed, thick, keeled, spirally arranged.

Male amentum small, terminal, cylindrical, with twelve to fifteen stamens. Fruit cones very small, terminal, about same size as the leaves, scales about four to eight in number. Seeds globular, about $\mathrm{I}$ line in diameter.

Geographical Range.-Restricted to Tasmania. 


\section{Celery Top Pine.}

(Phyllocladus rhomboidalis, Rich.)

This timber is pale coloured and rather harder than King William Pine (Athrotaxis selaginoides. It planes well and has an attractive figure, a close yet short grain, and is suitable for violins, panels, and almost anything that a light, easy working timber can be put to, either in joinery, cabinet work, or rolling stock on railways.

Description of the Tree.-A small tree, reaching its maximum height (6o feet) on the lower levels, and becoming dwarfed on the higher altitudes of the mountain ranges, the branches showing a tendency to a verticillate form of growth; the cladodia cuneate, or rhomboidal, obtuse, bluntly toothed or lobed, $x$ to 2 inches long, the leaf scales very small, and subulate. Male amentum cylindrical, stalked, solitary, or two or three together in the axils of leafy bracts; microsporophylls imbricate, on a short stipes, with a small connective having an apiculation or crest; the microsporangia are adnate, and two in number. The female amentum very smali, terminal, occurring along the edges of the phylloclade, consisting of a few macrosporophylls in a short spike, or a single one, and individually bearing a solitary, erect macrosporangium, the upper macrosporophyll occasionally being sterile. Fruiting scales thick, and fleshy, enclosing the base of the seed, which is ovoid, in a cup-shaped disc, the outer integument membraneous and not winged; the inner one crustaceous.

Geographical Range.-Endemic to Tasmania. 


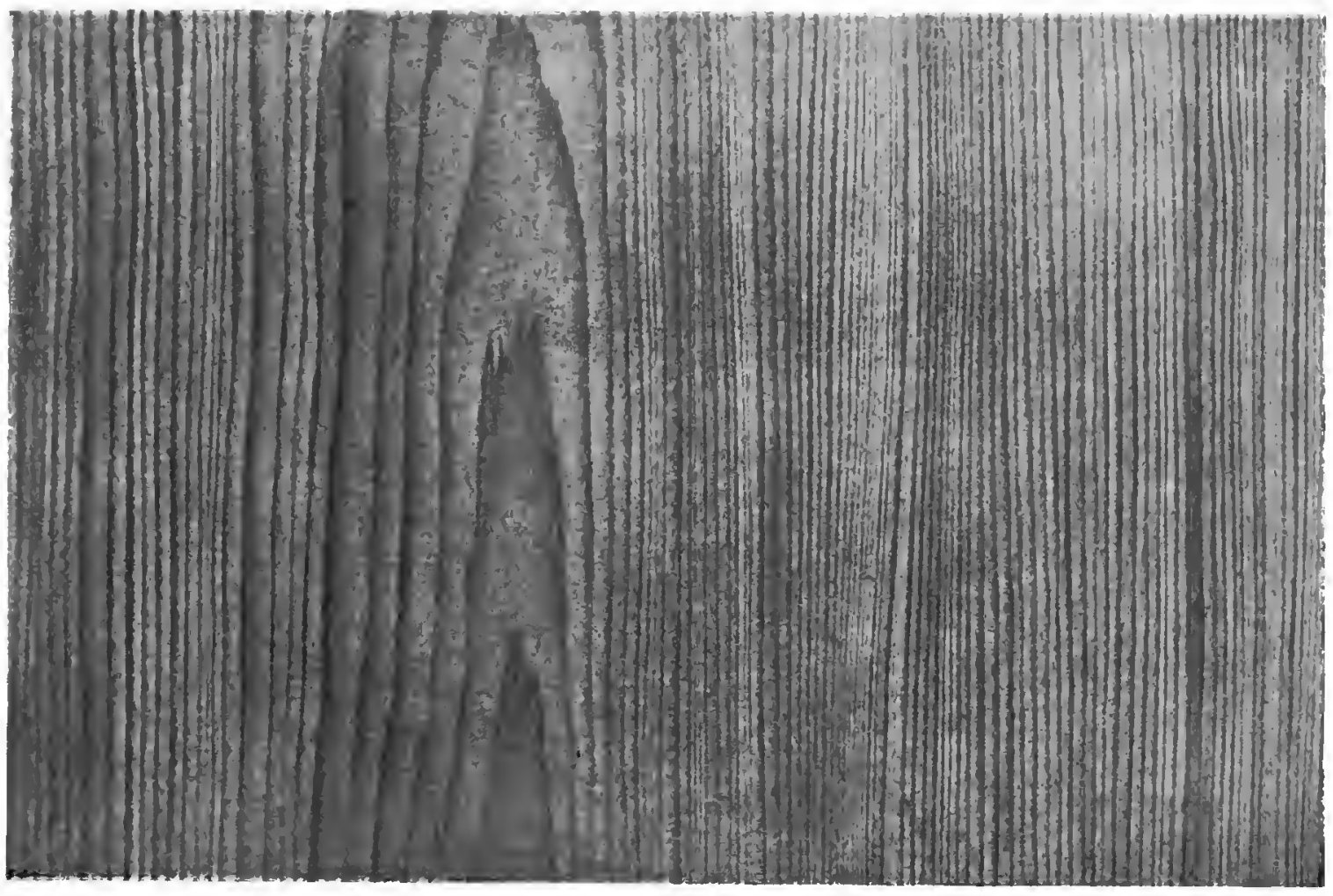

CELERY TOP PINE.

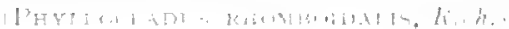




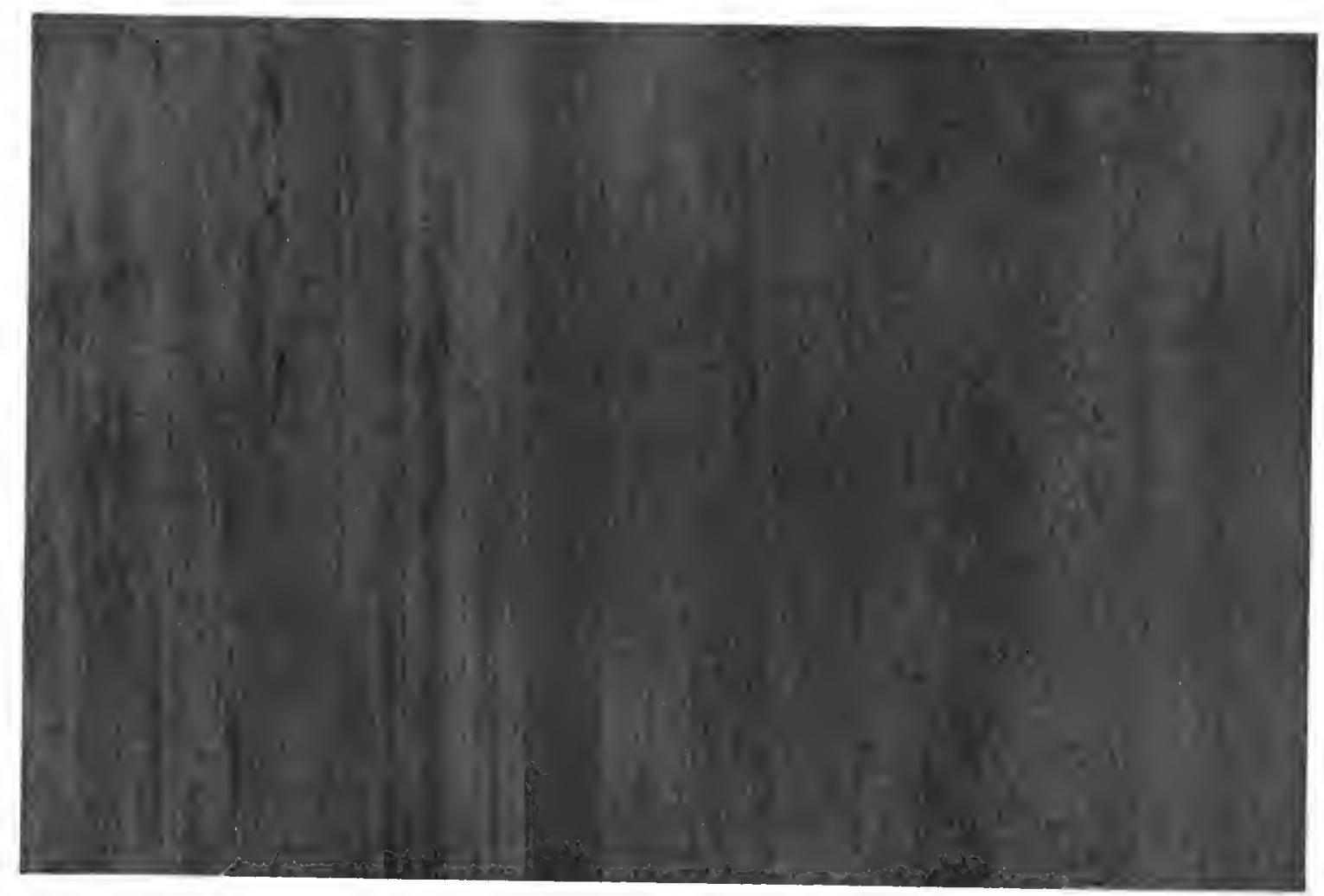

BROWN PINE.

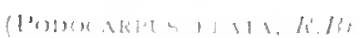




\title{
Brown Pine or Yellow Pine.
}

\author{
(Podocarpus elata, R.Br.)
}

It is a straight-growing tree in its native habitat, giving out few lateral branches, and consequently some fine planks can be procured of it. The timber is at first white, but tones down on exposure to a very pale brown. It is light in weight, soft, close grained, dresses beautifully, and is altogether a first-class pale-coloured timber for panelling, but when found with a figure, as occasionally happens, it is especially attractive. A column of this latter exhibited in the Museum is very beautiful. It is also suitable for wood carving, and is a useful, serviceable timber in either joinery or furniture, or internal decoration of railway cars,- seasoning well, and is fairly strong for a Pine.

Description of the Tree.-One of the largest trees of the brushes of the North Coast district of New South Wales and Southern Coast district of Queensland, where it attains a height of over roo feet. Leaves variable in length, measuring from 2 to 6 inches and occasionally 9 inches long, and about $\frac{1}{4}$ to $\frac{1}{2}$ inch broad, oblong, lanceolate, obtuse, midrib alone prominent, shortly petiolate. Male amenta, two or three together, sessile up to 2 inches long, subtended by short bracts. Female amentum very short, $4 \mathrm{~cm}$. long, solitary in the lower axils of the leaves. Fruiting receptacle $I \frac{1}{2} \mathrm{~cm}$. long, with one ovoid or globular seed $I_{4}^{1} \mathrm{~cm}$. in diameter.

Geographical Range.-It has rather a limited area of distribution, occurring as it does only in brushes of the East Coast of the continent. 


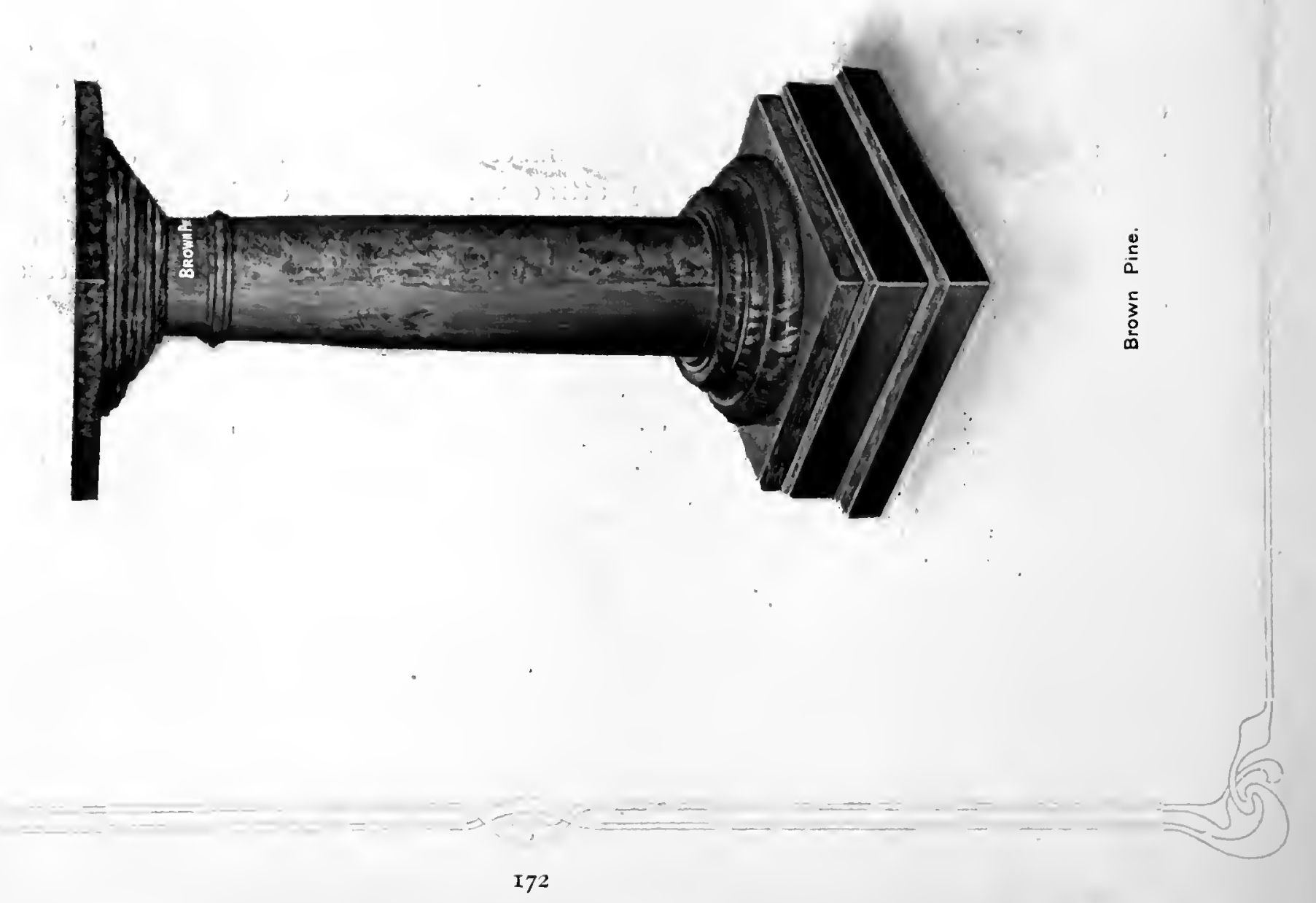




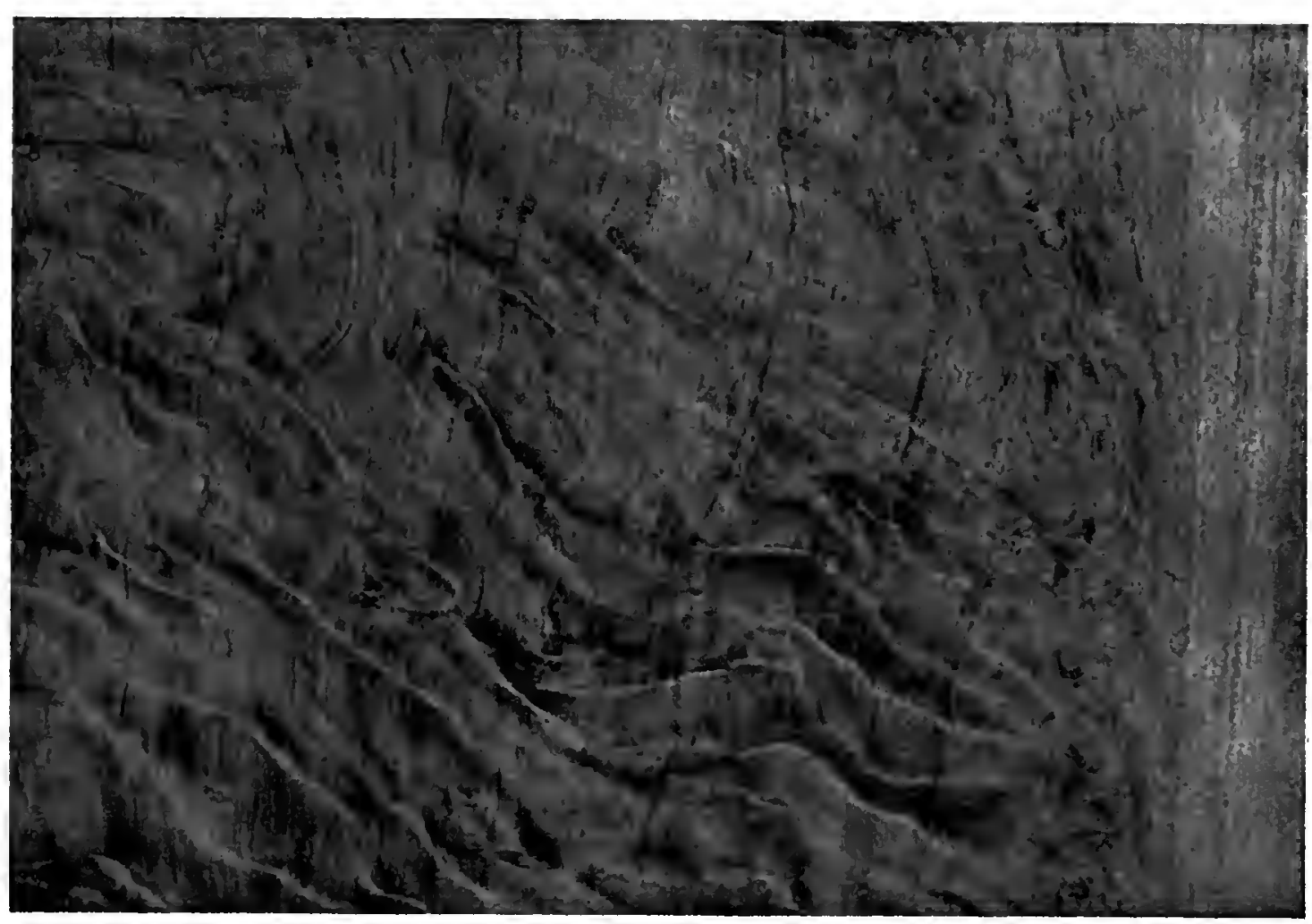

BROWN PINE. (Figured.1

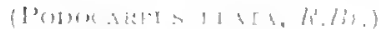




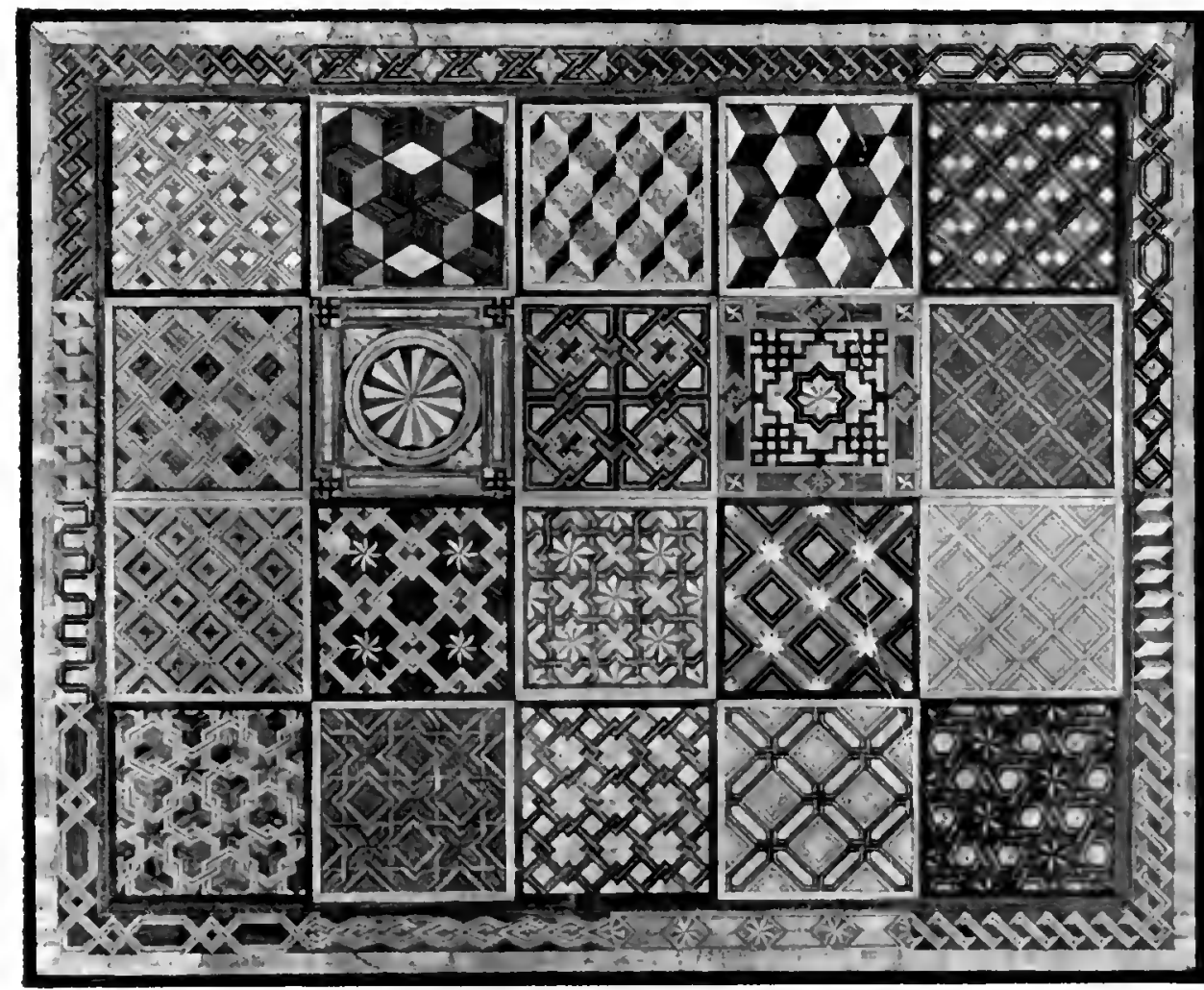




\section{Suggested Uses for these Cabinet Timbers.}

Architraves, Mouldings, Skirtings, Ec.-Maiden's Blush, Blue Fig, Cedar, Corkwood, Sassafras, She Beech or Bolly Gum, White Pine (Callitris glauca), Black Pine, King William Pine, Hoop Pine, Bunya Bunya Pine, Queensland Kauri, Huon Pine, Celery Top Pine, Brown Pine.

Balusters.-See under Turnery.

Banks, Hotels, Libraries, Offices, Shops, Ships' Cabins, Ships' Saloons, Éc. (Fittings for)-Crowsfoot Elm, Blue Fig, Rosewood, Red Bean, Onion Wood, Cedar, Queensland Maple, Black Bean, Blackwood, Jarrah, Sydney Blue Gum, Red Mahogany, Queensland Walnut, Silky Oak, White Honeysuckle, Red Myrtle, Hoop Pine, Queensland Kauri, Huon Pine, Mountain Ash, or Tasmanian Oak, Stringybark, Celery Top Pine, Brown Pine.

Billiard Tables.-See under Heavy Furniture.

Brush Backs.-See under Toilet Boxes.

Carving.-Beech, Black Bean, Cedar, Blackwood, Queensland Walnut, Red Myrtle, Brown Pine, Silky Oak, Fire Tree, Hoop Pine, Red Bean, Blue Fig, Queensland Kauri.

Coachbuilding, Road Vehicles (Finishing and Decorating).-Crowsfoot Elm, Maiden's Blush, Cedar, Black and Red Bean, Sally, Myall, Blackwood, Coachwood, Spotted Gum, Sydney Blue Gum, Silky Oak, Beefwood.

Colmmns.-See under Turnery.

Cornice Pole and Rings.-See under Toilet Boxes. 
Cottage Furniture.-Maiden's Blush, Blue Fig, Sassafras, King William Pine, Hoop Pine, Bunya Bunya Pine, Queensland Kauri, Huon Pine, Celery Top Pine, Brown Pine.

Cutlery Cases.--See under Toilet Boxes.

Dining Rooms.-See under Heavy Furniture.

Doors.-See under General Joinery Work.

Elevator Cars.--See under Railway Cars.

Flying Machines.-White Honeysuckle, Grey Plum.

Entrance Hall.-See under Heavy Furniture.

Framing.-See under General Joinery.

Furniture (Superior Class).-White Cedar, Rosewood, Red Bean, Cedar, Long Jack, Queensland Maple, New South Wales Maple, Red Ash, Yellow Cedar, Black Bean, Eumung, Sally, Blackwood, Coachwood, Spotted Gum, Iountain Ash, or Tasmanian Oak, Jarrah, Queensland Walnut, Silky Oak, Fire Tree, White Honeysuckle, Red Myrtle.

Furniture (Heavy).-See under Heavy Furniture.

General Joinery Work, Doors, Framing, Mantelpieces, Wainscotting, Ec.-Maiden's Blush, Blue Fig, White Cedar, Rosewood, Red Bean, Onion Wood, Cedar, Queensland Maple, Black Bean, Blackwood, Coachwood, Corkwood, Jarrah, Red Mahogany, Queensland Walnut, She Beech or Bolly Gum, Silky Oak, Red Myrtle, King William Pine, Mountain Ash, or Tasmanian Oak, Hoop Pine, Queensland Kauri, Huon Pine, Celery Top Pine, Brown Pine.

Heavy Furniture for Entrance Halls, Dining Rooms, Offices, Public Reception Rooms, Billiard Tables, Ecc.Crowsfoot Elm, Red Bean, Long Jack, Queensland Maple, New South Wales Maple, Red Asl, Black Bean, Blackwood, Myall, Brigalow, Spotted Gum, Jarrah, Sydney Blue Gum, Slaty Gum, Red Box, Red Mahogany, River Oak, Swamp Oak, Belah, Forest Oak.

Hotels.-See under Banks.

Jewellery Cases.-See under Toilet Boxes. 
Libraries (Interior Fittings).- See under Banks.

Mantelpieces.-See under General Joinery.

Mathematical Instrument Cases.-See under Toilet Boxes.

Mouldings.-See under Architraves.

Newels.-See under Turnery.

Offices (Heavy Furniture).-See under Heavy Furniture.

Offices.-See under Libraries.

Pillarettes.-See under Turnery.

Public Reception Rooms.-See under Heavy Furniture

Railway Cars, Tramway, and Elevator Cars (Interior Finishing and Decorating).—Crowsfoot Elm, Maiden's Blush, Blue Fig, Scrub Hickory, Rosewood, Red Bean, Cedar, Queensland Maple, Black Bean, Blackwood, Tortoise Shell Tulip, Coachwood, Queensland Walnut, Silky Oak, Fire Tree, White Honeysuckle, Beefwood, Red Myrtle, White Pine, Black Pine, King William Pine, Hoop Pine, Queensland Kauri, Huon Pine, Celery Top Pine, Brown Pine.

Road Vehicles.-See under Coachbuilding.

Scientific Instrument Cases.-See under Toilet Boxes.

Ships' Cabins.- See under Banks.

Shops.-See under Libraries. 
Skirting.-See under Architraves.

Toilet Boxes, Brush Backs, Cutlery Cases, Jewellery Cases or Caskets, Mathematical and Scientific Instrument Cases, Cornice Pole and Rings, Trays, \&c.-Crowsfoot Elm, Thorny Yellow Wood, Scrub Hickory, Rosewood, Red Bean, New South Wales Maple, Supple Jack, Tulip Wood, Yellow Cedar, Black Bean, Eumung, Sally, Myall, Brigalow, Gidgea, Tortoise Shell Tulip, Red Box, Musk, Budda, Silky Oak, Beefwood, Victorian Waratah, Tasmanian Waratah, Fire Tree, White Honeysuckle, Swamp She Oak, Bull Oak, Belah, Forest Oak, Cherry Tree, White Pine, Black Pine.

Tramway Cars.-See under Railway Cars.

Trays.-See under Toilet Boxes.

Tumery Work, Newels, Balusters, Columns, Pillarettes, Ec.-Rosewood, Red Bean, Onion Wood, Cedar, Supple Jack, Red Ash, Tulip Wood, Yellow Cedar, Eumung, Blackwood, Myall, Brigalow, Gidgea, Corkwood, Red Box, Red Mahogany, Musk, Budda, Beech, Silky Oak, River Oak, Swamp Oak, Bull Oak, Forest Oak, Cherry Tree, White Pine (Glanca), Black Pine, Hoop Pine, Queensland Kauri, Celery Top Pine, Brown Pine.

Violins.-King William Pine.

Wainscotting.-See under General Joinery.

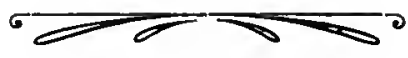




\section{Types of Specific Gravity.}

In the following Summary (Io) under the column of weights, timbers are specified as light, medium, and heavy.

These results were obtained by taking three specimens of Australian timbers, standard testing size, as types of each class, and then comparing the data of exotic timbers of equal dimensions with these three, and thus in some degree, a comparative weight classification was arrived at. The specimens were all well seasoned.

Types of Each Class.

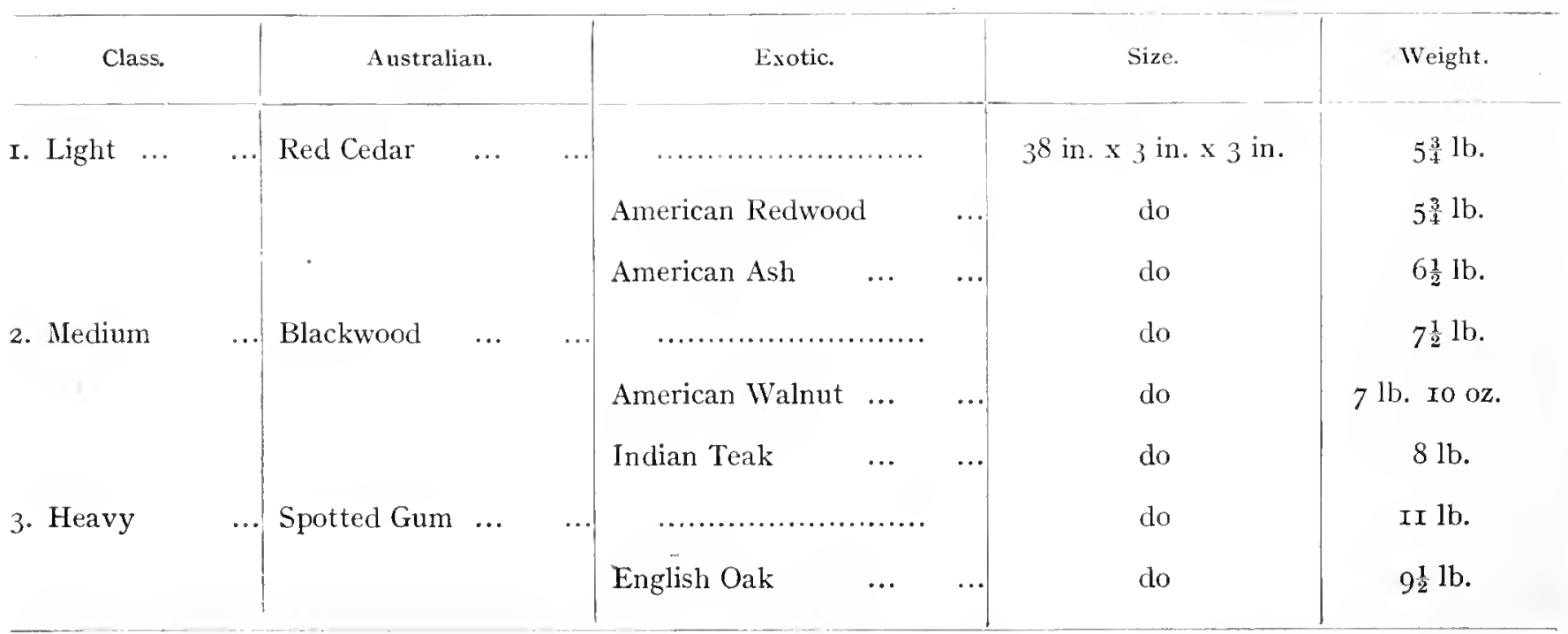




\section{Summary.}

\begin{tabular}{|c|c|c|c|c|c|c|c|c|c|c|c|}
\hline \multirow{2}{*}{ 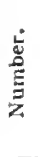 } & \multirow{2}{*}{\multicolumn{3}{|c|}{ Name of Timber. }} & \multicolumn{3}{|c|}{ Specific Gravity or Weight. } & \multicolumn{3}{|c|}{$\begin{array}{l}\text { Relative facility in working } \\
\text { with ordinary hand planes. }\end{array}$} & \multirow{2}{*}{ Colour. } & \multirow{2}{*}{$\begin{array}{l}\text { Description of figure, } \\
\text { flower, or grain. }\end{array}$} \\
\hline & & & & Light. & Medium. & Heavs: & liasy. & $\begin{array}{l}\text { A little } \\
\text { difficult. }\end{array}$ & $\begin{array}{l}\text { Cross- } \\
\text { grained and } \\
\text { difficult. }\end{array}$ & & \\
\hline $\mathbf{I}$ & Crowsfoot Elm & $\cdots$ & $\cdots$ & $\cdots$ & $x$ & $\cdots$ & $\cdots$ & $x$ & $\cdots$ & $\begin{array}{l}\text { Light brown witl silvery } \\
\text { streaks. }\end{array}$ & $\begin{array}{l}\text { Radial face shows a pretty } \\
\text { figure, finer than Silky Oak. }\end{array}$ \\
\hline 2 & Maiden's Bluslı & $\cdots$ & $\cdots$ & $x$ & $\cdots$ & $\cdots$ & $\times$ & $\cdots$ & $\ldots$ & Warm pink after exposure & $\begin{array}{l}\text { Radial section shows pretty, } \\
\text { small figure similar to New } \\
\text { South Wales Maple. }\end{array}$ \\
\hline 3 & Blue Fig & $\cdots$ & $\cdots$ & $x$ & $\cdots$ & $\cdots$ & $x$ & $\cdots$ & $\cdots$ & $\begin{array}{c}\text { Almost white with faint } \\
\text { tinge of yellow. }\end{array}$ & $\begin{array}{l}\text { Plain, but takes a stain re- } \\
\text { markably well. }\end{array}$ \\
\hline 4 & Thorny Yellow Wo & & $\cdots$ & $\cdots$ & $x$ & $\cdots$ & $\cdots$ & $x$ & $\cdots$ & $\begin{array}{l}\text { Yellowish wood with dark } \\
\text { streaks. }\end{array}$ & Small wavy figure. \\
\hline 5 & Scrub Hickory & $\cdots$ & $\cdots$ & $\cdots$ & $x$ & $\cdots$ & $\cdots$ & $x$ & $\cdots$ & $\begin{array}{l}\text { Bright yellowish when } \\
\text { polisheil. }\end{array}$ & $\begin{array}{l}\text { Plain, but fairly strong and } \\
\text { tough. }\end{array}$ \\
\hline 6 & White Cedar ... & $\cdots$ & $\cdots$ & $\times$ & $\cdots$ & $\cdots$ & $x$ & $\cdots$ & $\cdots$ & Pale brown $\quad \ldots$ & $\begin{array}{l}\text { Large pronounced figure, simi- } \\
\text { lar to English Elm. }\end{array}$ \\
\hline 7 & Rosewood & $\cdots$ & ... & $\cdots$ & $x$ & $\cdots$ & $\cdots$ & $x$ & $\cdots$ & Pale red $\ldots \quad \quad \ldots$ & $\begin{array}{l}\text { Good figure, similar in some } \\
\text { respects to Spanish Ma. } \\
\text { logany. }\end{array}$ \\
\hline $\begin{array}{l}8 \\
9\end{array}$ & $\begin{array}{cc}\text { Red Bean } & \ldots \\
\text { Do } & \ldots\end{array}$ & $\begin{array}{l}\cdots \\
\ldots\end{array}$ & $\ldots$ & $\begin{array}{l}\cdots \\
\cdots\end{array}$ & $\begin{array}{l}x \\
x\end{array}$ & $\begin{array}{l}\cdots \\
\ldots\end{array}$ & $\cdots$ & $\begin{array}{l}x \\
x\end{array}$ & $\ldots\}$ & Red $\quad \ldots$ & Very similar to Rosewood. \\
\hline 10 & Onion Wood ... & $\cdots$ & $\cdots$ & $\cdots$ & $x$ & $\cdots$ & $\dddot{x}$ & $\cdots$ & $\cdots$ & Redklish brown $\quad \ldots \quad \ldots$ & $\begin{array}{l}\text { Very like Cedar in grain, but } \\
\text { slightly larder and heavier. }\end{array}$ \\
\hline II & Cedar (Red) ... & $\cdots$ & $\cdots$ & $x$ & $\cdots$ & $\cdots$ & $x$ & $\cdots$ & $\cdots$ & Bright to clark red & $\begin{array}{l}\text { Good ornamental figure with } \\
\text { great variations. }\end{array}$ \\
\hline I 2 & Long Jack $\ldots$ & $\cdots$ & $\cdots$ & $\ldots$ & $x$ & $\cdots$ & $\ldots$ & $x$ & $\cdots$ & Yellow or straw colour ... & Comparatively plain. \\
\hline I 3 & Maple (Queensland) & ).. & ... & $\ldots$ & $x$ & $\cdots$ & $\cdots$ & $x$ & $\cdots$ & Lightislı brown $\ldots$ & $\begin{array}{l}\text { Good ornamental figure with } \\
\text { considerable variety. }\end{array}$ \\
\hline I4 & Do New South & Males) & $\ldots$ & $\cdots$ & $x$ & $\ldots$ & $\cdots$ & $\times$ & $\cdots$ & $\begin{array}{l}\text { Pale colour, slight yellow } \\
\text { tinge. }\end{array}$ & $\begin{array}{l}\text { Rather sisall, pretty, flowery } \\
\text { figure. }\end{array}$ \\
\hline I 5 & Supple Jack ... & $\cdots$ & $\ldots$ & $\cdots$ & $\cdots$ & $x$ & $\cdots$ & $\cdots$ & $x$ & $\begin{array}{l}\text { Outside white, heartwool } \\
\text { dark cliestnut. }\end{array}$ & Fairly good, very like Myall. \\
\hline 16 & Red Ash & $\cdots$ & $\cdots$ & $\cdots$ & $x$ & $\cdots$ & $\cdots$ & $x$ & $\cdots$ & $\begin{array}{l}\text { Heart portion red, outer } \\
\text { portion light. }\end{array}$ & \\
\hline
\end{tabular}




\section{Summary - continued.}

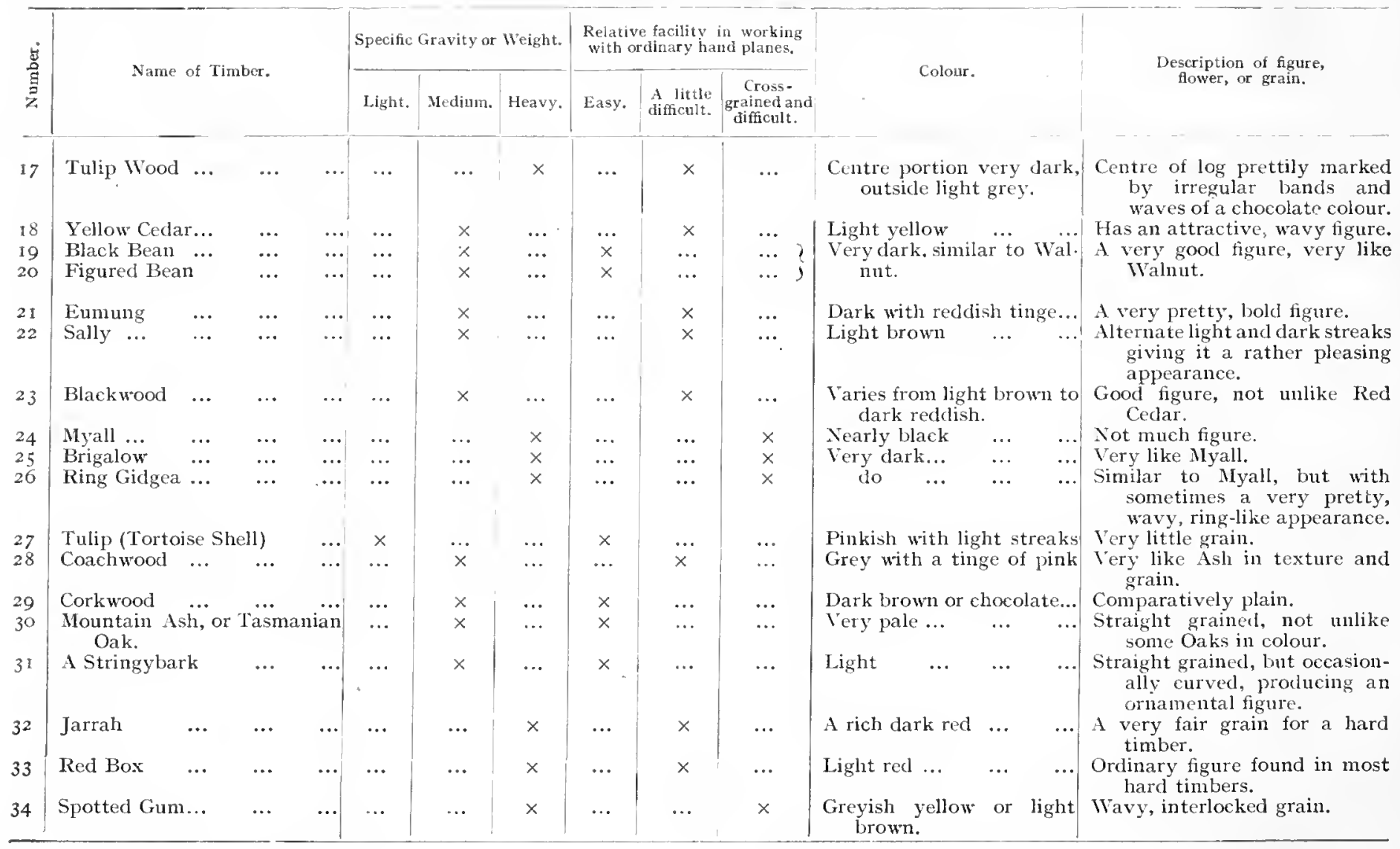


SUMMARY -continued.

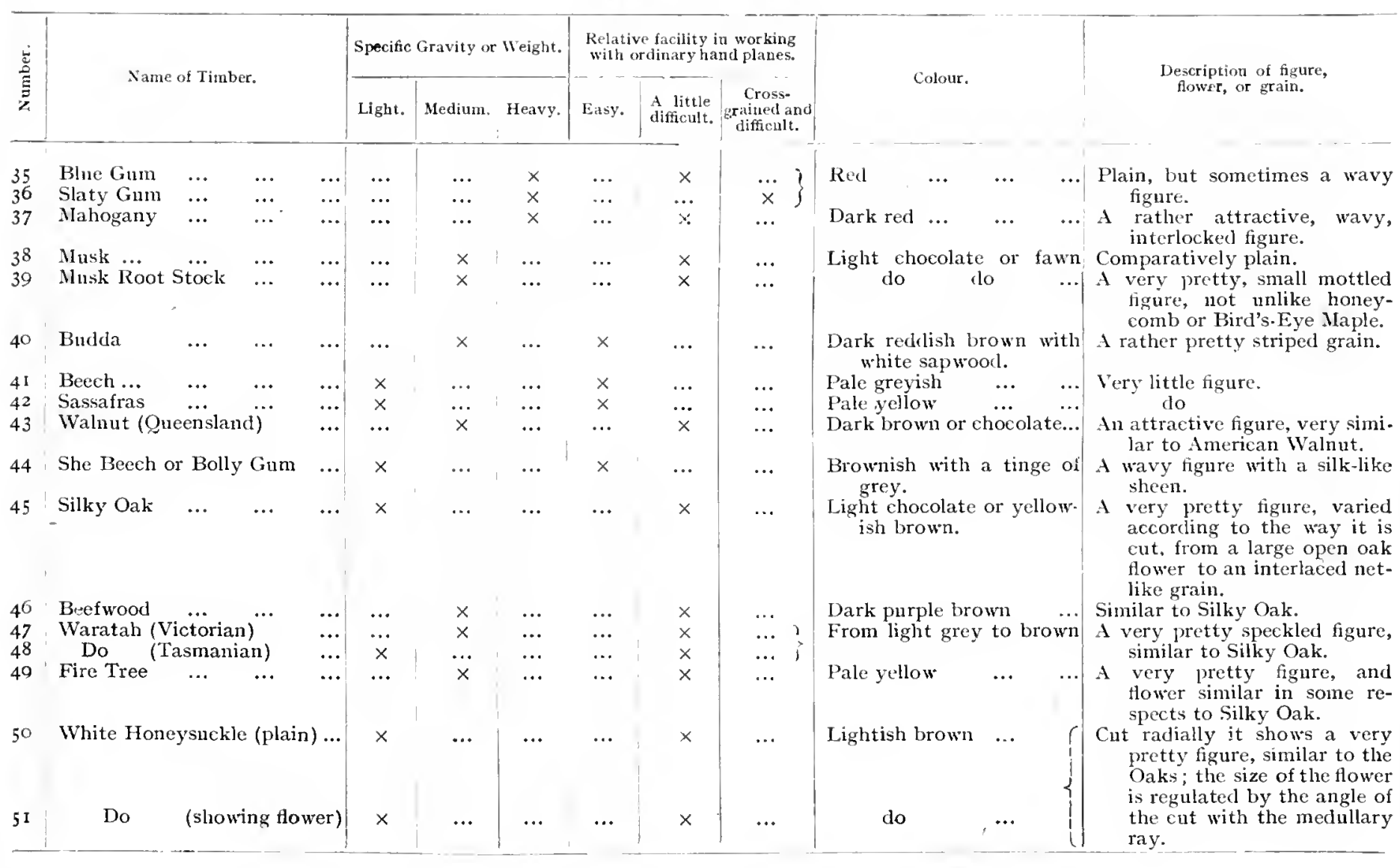


SUMMARY - continued.

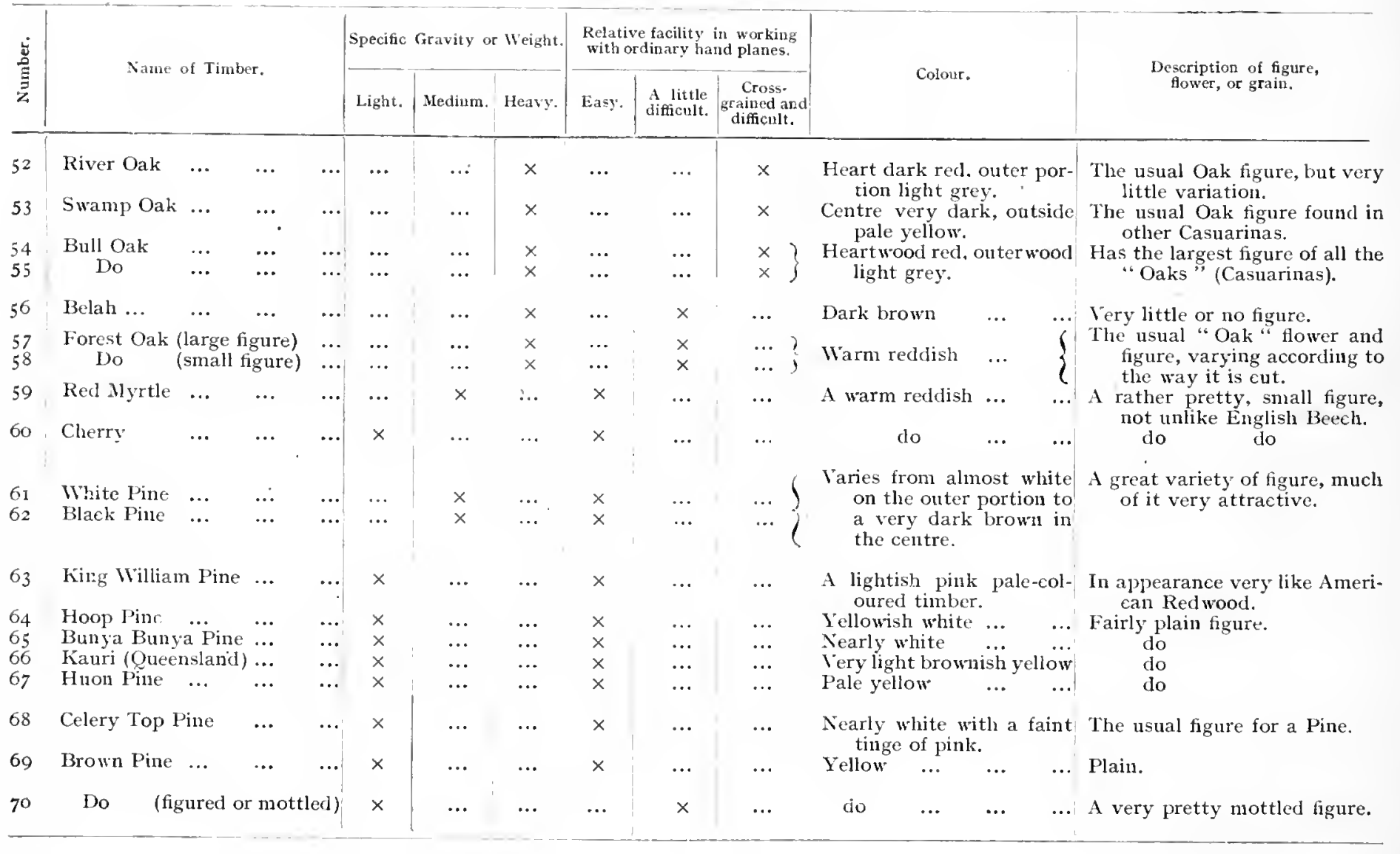




\section{INDEX.}

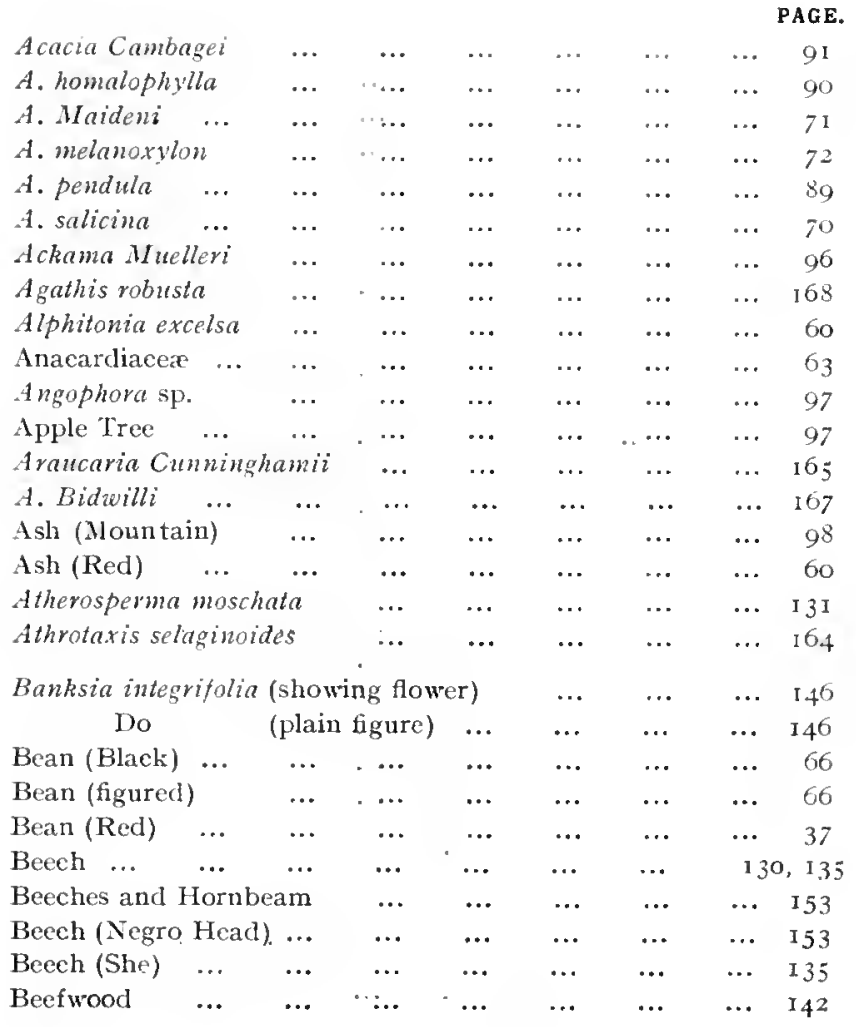

\begin{tabular}{|c|c|c|c|c|c|c|c|c|}
\hline Belah ... & $\cdots$ & $\cdots$ & $\cdots$ & $\cdots$ & $\cdots$ & $\cdots$ & $\cdots$ & 151 \\
\hline Black Bean & $\cdots$ & ... & $\cdots$ & .. & ... & ... & $\ldots$ & 66 \\
\hline Black Pine & $\cdots$ & $\cdots$ & $\cdots$ & $\cdots$ & $\cdots$ & $\cdots$ & $\cdots$ & $16 \mathrm{I}$ \\
\hline Blackwood & $\ldots$ & .. & $\cdots$ & .. & ... & $\cdots$ & $\cdots$ & 72 \\
\hline Blue Fig & $\cdots$ & $\cdots$ & $\cdots$ & ... & $\cdots$ & $\cdots$ & $\ldots$ & 28 \\
\hline Blue Gum & $\cdots$ & $\cdots$ & $\cdots$ & $\cdots$ & $\cdots$ & $\cdots$ & $\ldots$ & 122 \\
\hline Bolly Gum & $\cdots$ & $\cdots$ & $\cdots$ & $\cdots$ & $\cdots$ & $\cdots$ & $\cdots$ & 135 \\
\hline Box (Red) & $\cdots$ & $\cdots$ & $\cdots$ & $\cdots$ & $\cdots$ & $\cdots$ & $\cdots$ & 119 \\
\hline Brigalow & $\cdots$ & $\cdots$ & $\cdots$ & $\cdots$ & $\cdots$ & $\cdots$ & $\cdots$ & 90 \\
\hline Brown Pine & $\cdots$ & $\cdots$ & $\cdots$ & $\cdots$ & $\cdots$ & $\cdots$ & $\cdots$ & I $7 \mathrm{I}$ \\
\hline Budda ... & $\cdots$ & $\cdots$ & $\cdots$ & $\cdots$ & $\cdots$ & $\cdots$ & $\cdots$ & I 28 \\
\hline Bull Oak & $\cdots$ & $\cdots$ & $\cdots$ & $\cdots$ & $\cdots$ & $\cdots$ & $\cdots$ & I 50 \\
\hline Bunya Bunya & & $\cdots$ & $\cdots$ & $\cdots$ & $\cdots$ & $\cdots$ & $\cdots$ & 167 \\
\hline Callitris calcar & ata & $\cdots$ & $\cdots$ & $\cdots$ & $\cdots$ & $\cdots$ & $\cdots$ & 161 \\
\hline C. glanca & $\cdots$ & $\cdots$ & $\cdots$ & $\cdots$ & $\cdots$ & $\cdots$ & $\cdots$ & I 59 \\
\hline Camphor Laur & & $\ldots$ & $\cdots$ & $\cdots$ & $\cdots$ & $\cdots$ & $\ldots$ & 128 \\
\hline Carata mulucce & ensis & $\cdots$ & $\cdots$ & $\cdots$ & $\cdots$ & $\cdots$ & $\cdots$ & 32 \\
\hline Castanospermu & tm aust & rale & $\cdots$ & $\cdots$ & $\cdots$ & $\cdots$ & $\cdots$ & 66 \\
\hline Casuarimea & $\cdots$ & $\cdots$ & $\cdots$ & $\cdots$ & $\cdots$ & $\cdots$ & $\cdots$ & 147 \\
\hline Casuarina Cam & nbagei & $\cdots$ & $\cdots$ & $\cdots$ & $\cdots$ & $\cdots$ & $\cdots$ & I $5 \mathrm{I}$ \\
\hline C. Cunninghan & $m i i$ & $\ldots$ & $\cdots$ & $\cdots$ & $\cdots$ & $\cdots$ & $\cdots$ & I. 48 \\
\hline C. glauca & $\ldots$ & $\cdots$ & $\cdots$ & $\cdots$ & $\cdots$ & $\cdots$ & $\cdots$ & I 49 \\
\hline C. Luehmanni & & $\cdots$ & $\cdots$ & $\cdots$ & $\cdots$ & $\cdots$ & $\cdots$ & I $5^{\circ}$ \\
\hline C. torulosa $(\mathrm{sm}$ & hall figu & are) & $\cdots$ & $\cdots$ & $\cdots$ & $\cdots$ & $\cdots$ & 152 \\
\hline Do (lar & ge figu & re) & $\cdots$ & $\cdots$ & $\cdots$ & $\cdots$ & $\cdots$ & 152 \\
\hline Cedar (Hondur & ras) & $\cdots$ & $\cdots$ & $\cdots$ & $\cdots$ & $\cdots$ & $\cdots$ & 32 \\
\hline Cedar (Red) & $\cdots$ & $\ldots$ & $\cdots$ & $\therefore$ & $\cdots$ & $\therefore$ & $\cdots$ & 39 \\
\hline Cedar (White) & $\cdots$ & $\cdots$ & $\cdots$ & $\cdots$ & $\cdots$ & ... & ... & 33 \\
\hline
\end{tabular}




\section{INDEX-continued.}

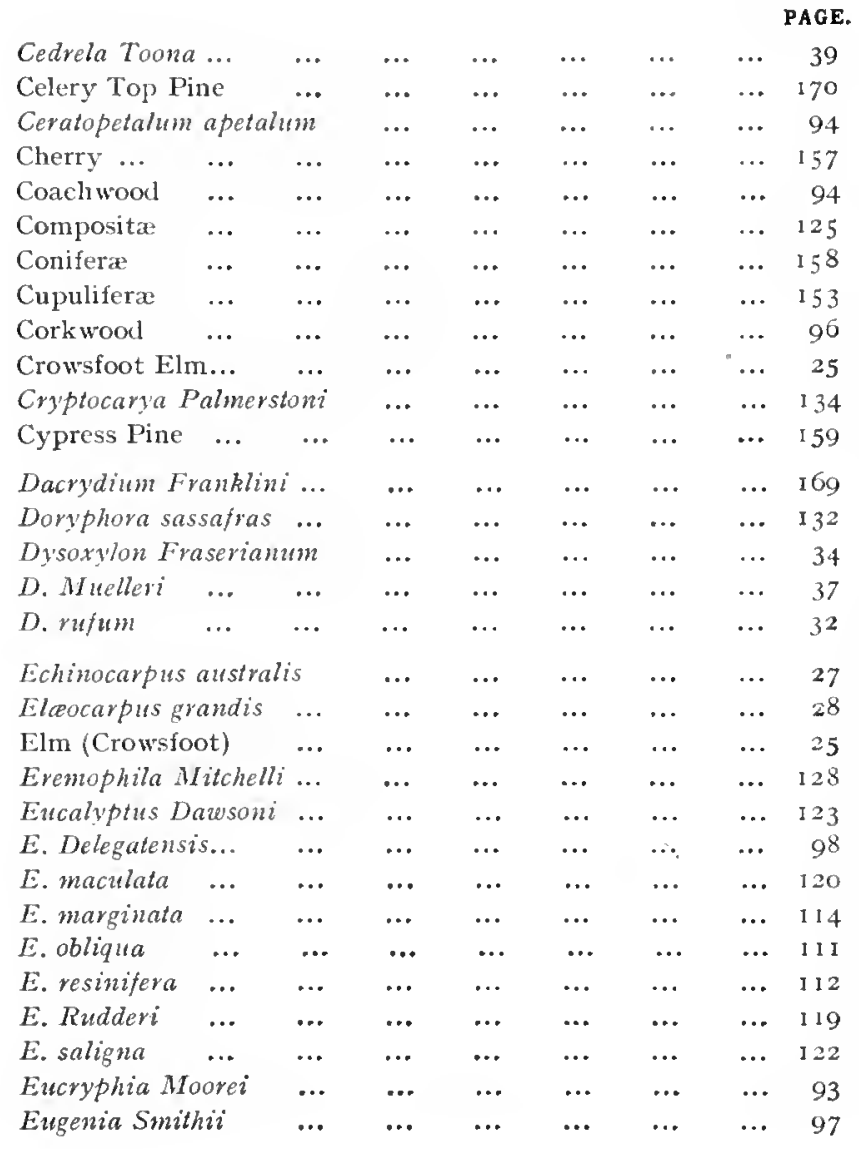

Eumung

PAGE.

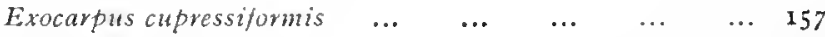

$\begin{array}{lllllllll}\text { Fagus Cunninghamii ... } & \ldots & \ldots & \ldots & \ldots & \ldots & 154\end{array}$

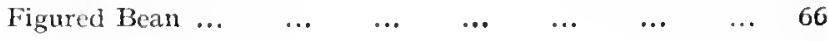

$\begin{array}{lllllllll}\text { Fire Tree } & \ldots & \ldots & \ldots & \ldots & \ldots & \ldots & \ldots & 145\end{array}$

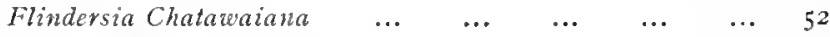

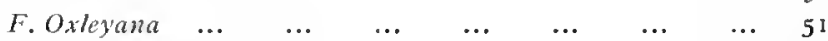

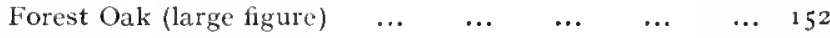

Do (small figure) $\quad \ldots \quad \ldots \quad \ldots \quad \ldots \quad \ldots \quad \ldots \quad$ I 52

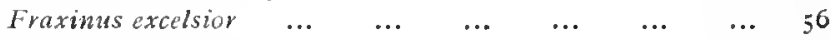

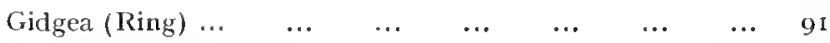

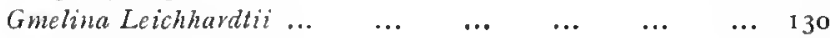

$\begin{array}{lllllllll}\text { Grevillea robusta } & \ldots & \ldots & \ldots & \ldots & \ldots & \ldots & 137\end{array}$

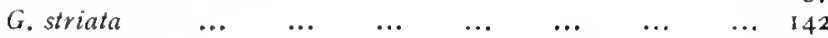

$\begin{array}{llllllllll}\text { Gum }(\text { Slaty) } & \ldots & \ldots & \ldots & \ldots & \ldots & \ldots & \ldots & 123\end{array}$

$\begin{array}{llllllllll}\text { Gum, Spotted } & \ldots & \ldots & \ldots & \ldots & \ldots & \ldots & \ldots & 97\end{array}$

$\begin{array}{lllllllll}\text { Harpullia pendula } & \ldots & \ldots & \ldots & \ldots & \ldots & \ldots & 62\end{array}$

$\begin{array}{lllllllll}\text { Hickory }(\text { Scrub) } & \ldots & \ldots & \ldots & \ldots & \ldots & \ldots & 31\end{array}$

$\begin{array}{lllllllll}\text { Honduras Cedar } & \ldots & \ldots & \ldots & \ldots & \ldots & \ldots & 32\end{array}$

$\begin{array}{llllllll}\text { Honduras Mahogany } & \ldots & \ldots & \ldots & \ldots & \ldots & \ldots & 32\end{array}$

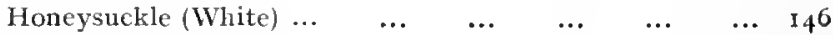

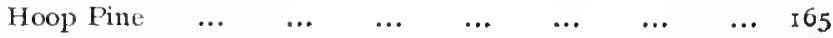

$\begin{array}{llllllll}\text { Hormbeam and Beech } & \ldots & \ldots & \ldots & \ldots & \ldots & \text { I } 52\end{array}$

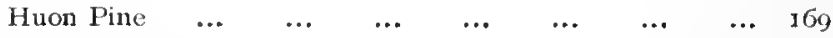

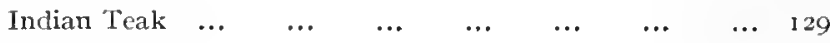

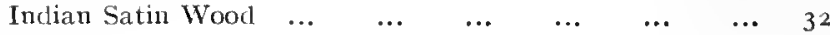

$\begin{array}{llllllllll}\operatorname{Jarrah} & \ldots & \ldots & \ldots & \ldots & \ldots & \ldots & \ldots & \ldots & 114\end{array}$

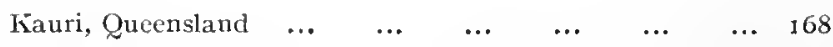

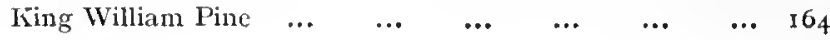




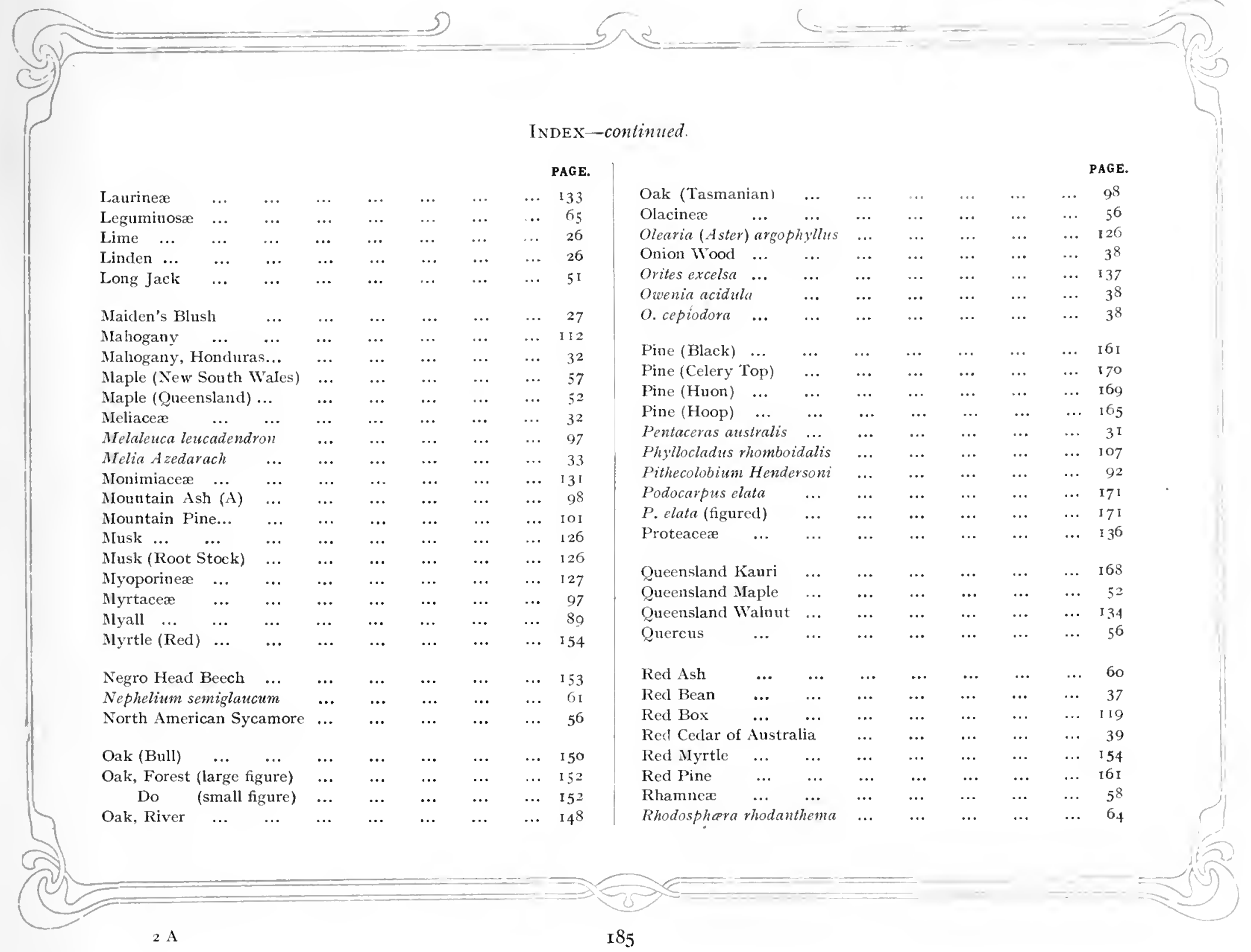




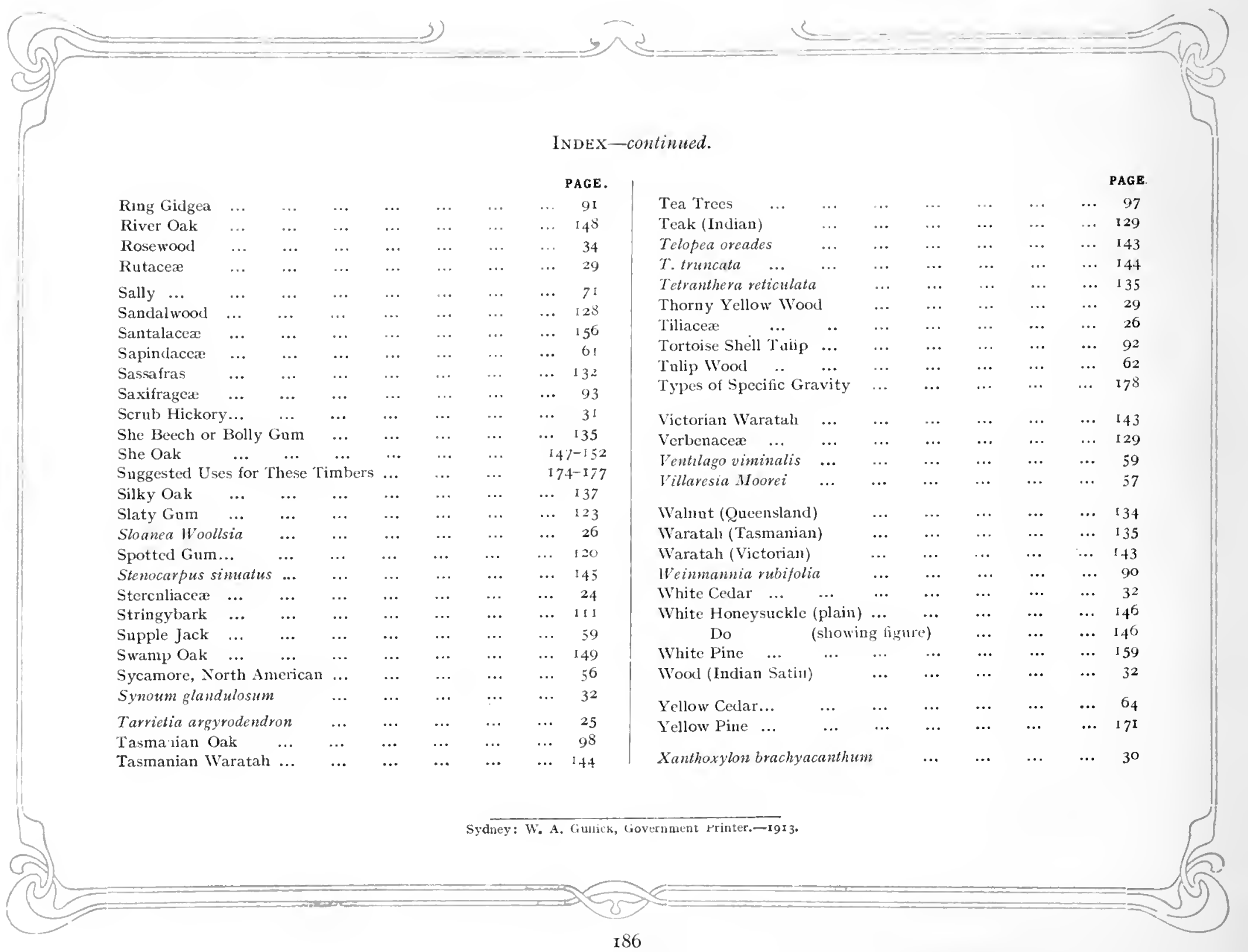




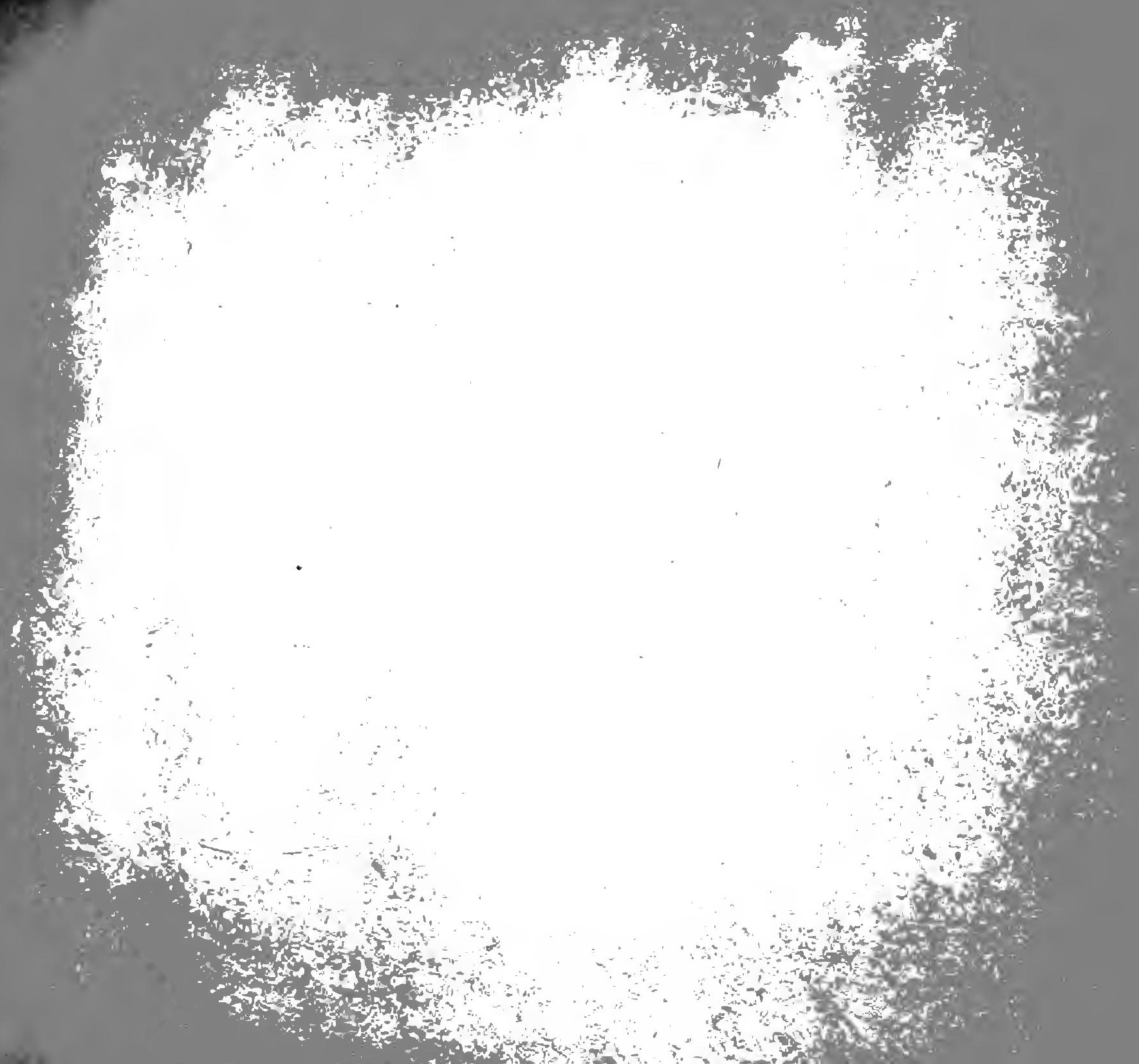


THIS BOOK IS DUE ON THE LAST DATE STAMPED BELOW

AN INITIAL FINE OF 25 CENTS WILL BE ASSESSED FOR FAILURE TO RETURN THIS BOOK ON THE DATE DUER FAILURE TO RETURN THIS BOOK ON THE DATE DUE. THE PENALTY WILL INCREASE TO SEVENTH DAY OVERDUE.

MAY 1 C :DE

REID MAY $3 \quad 1967$

LU LIBKARY

DUE JAN 51972

UCDAMRIRARCD

DUE APR 41977

APR 20 DER'

\section{UCD LIBRARY}

DUE JUN 301982

JUN 81982 RECD 

